ANDERSON MANZOLI

\title{
ANÁLISE DAS EMISSÕES VEICULARES EM TRAJETOS URBANOS CURTOS COM LOCALIZAÇÃO POR GPS
}





\section{ANDERSON MANZOLI}

\section{ANÁLISE DAS EMISSÕES VEICULARES EM TRAJETOS URBANOS CURTOS COM LOCALIZAÇÃO POR GPS}

Tese apresentada à Escola de Engenharia de São Carlos da Universidade de São Paulo, para obtenção do título de Doutor em Engenharia Civil.

Área de Concentração: Transportes

Orientador: Prof. Dr. Ricardo Ernesto Schaal 
AUTORIZO A REPRODUÇÃO E DIVULGAÇÃO TOTAL OU PARCIAL DESTE TRABALHO, POR QUALQUER MEIO CONVENCIONAL OU ELETRÔNICO, PARA FINS DE ESTUDO E PESQUISA, DESDE QUE CITADA A FONTE.

Ficha catalográfica preparada pela Seção de Tratamento da Informaçẫo do Serviço de Biblioteca - EESC/USP

M296a

Manzoli, Anderson

Análise das emissões veiculares em trajetos urbanos curtos com localização por GPS / Anderson Manzoli ;

orientador Ricardo Ernesto Schaal. -- São Carlos, 2009.

Tese (Doutorado-Programa de Pós-Graduação e Área de Concentração em Engenharia de Transportes) -- Escola de Engenharia de São Carlos da Universidade de São Paulo, 2009 .

1. Emissão de $\mathrm{CO}$ e HC. 2. Trajetos curtos - Motor frio. 3. Localização por GPS. I. Título. 


\section{Dedicatória}

Aos meus pais, a minha esposa e ao meu filho 



\section{Agradecimentos}

A Deus, pelas oportunidades que me foram dadas na

vida.

À minha família, pelo carinho e pela ajuda nas dificuldades.

Ao prof. Dr. Ricardo Ernesto Schaal, pelo apoio e incentivo.

Aos profs. Dr. Antônio Moreira dos Santos e Dr. Nemésio Neves Batista Salvador, pelas sugestões durante o exame de qualificação.

Ao Prof. Dr. Ozíride Manzoli Neto, pela ajuda constante.

À profa . Dr ${ }^{\mathrm{a}}$ Luciana Romano Morilas, pela leitura atenta.

À Elena Luzia Palloni Gonçalves, pela correção de toda a referenciação bibliográfica do trabalho.

Aos professores e funcionários do Departamento de Transportes da Escola de Engenharia da USP de São Carlos.

Aos colegas do curso de pós-graduação em Transportes, pelas conversas instigantes do corredor.

À Tecnomotor, pelo empréstimo do analisador de gases usado durante os ensaios.

Ao Centro de Caracterização e Desenvolvimento de Materiais (CCDM - UFSCar/UNESP), pela análise do combustível.

Ao CNPq, pelo apoio financeiro. 



\section{Resumo}

MANZOLI, A.(2009). Análise das emissões veiculares em trajetos urbanos curtos com localização por GPS. 175 p. Tese (Doutorado) - Escola de Engenharia de São Carlos, Universidade de São Paulo, São Carlos.

Estuda-se o problema da emissão de gases por veículos automotores movidos a gasolina em trajetos curtos percorridos em cidades pequenas e médias. Nessa situação, o tipo de percurso que ocorre com mais frequência é curto, o que significa circulação de veículos com os motores ainda frios. Sabe-se que esta circunstância constitui a condição menos favorável no que se refere à emissão de gases poluentes. Tecnologias recentes, como GPS e analisadores de gases portáteis, foram usados para se obterem dados fundamentais para o trabalho, como velocidade, tempo, coordenada espacial, aceleração, mensuração da emissão dos poluentes pelo escapamento do veículo e temperatura do motor. Os testes foram feitos com o motor frio e quente para que fosse possível descrever o comportamento da emissão dos gases nas duas condições. Determinou-se experimentalmente a emissão de $\mathrm{CO}$ e $\mathrm{HC}$ em diversas condições e construiu-se um banco de dados sobre como esses parâmetros interferem na geração desses gases nos percursos estabelecidos, fornecendo uma previsão mais realista. Os resultados pretendem conscientizar os administradores públicos acerca da necessidade de se mensurar a real emissão de poluentes em qualquer cidade, pois o número reduzido de automóveis não significa diretamente a inexistência de problemas com a poluição. Especialmente no caso das cidades pequenas e médias, esse resultado pode subsidiar uma política preventiva, para que não se alcancem os níveis catastróficos que hoje são encontrados nas grandes cidades.

Palavras-chave: Emissão de CO e HC. Trajetos curtos. Motor frio. Localização por GPS. 



\section{Abstract}

Manzoli, A. (2009) "Vehicle emission analysis in urban short distances with GPS localization". 175 p. Doctor thesis - Engineering School of São Carlos, Department of Transportation, University of São Paulo.

This work studies the problem of gas emission by automotive petrol moved vehicles in short distances travelled in small and medium towns. In this situation, most distances are short. It means that vehicle circulates commonly with still cold engine, what is known to be the least favorable condition concerned to pollutant gas emission. Recent technologies like GPS and portable gas analyzers were used to obtain fundamental data, like speed, time, spacial coordinate, acceleration, pollutant emission by vehicle leakage and engine temperature. The tests were made with cold and hot engine, so that it would be possible to describe the gas emission behavior in both conditions. $\mathrm{CO}$ and $\mathrm{HC}$ emission were determined experimentally in several conditions and a data base was built after how these parameters interfere in the gas emission in the established routes, providing a more realistic view. These data can help public administrators to think about the need to measure the real pollutants emission in any town, because the reduced number of automobiles isn't directly related to the inexistence of pollution problems. Specially related to short and medium towns, this result may supply preventive politics, so that the catastrophic levels found in big cities nowadays won't be held.

Key-words: $\mathrm{CO}$ and $\mathrm{HC}$ emission. Short distances. Cold engine. GPS localization. 



\section{Lista de figuras}

Figura 2.1.1 - Esquema simplificado da utilização da energia dos combustíveis fósseis nos transportes............ 13

Figura 2.1.2 - Consumo de energia por setores finais em São Paulo (trilhões de Kcal/ano)............................... 14

Figura 2.1.3 - A influência dos poluentes nos receptores .......................................................................... 14

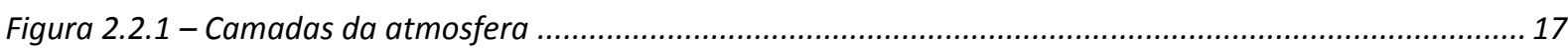

Figura 2.2.2 - Escala temporal e espacial de alguns constituintes da atmosfera ............................................20

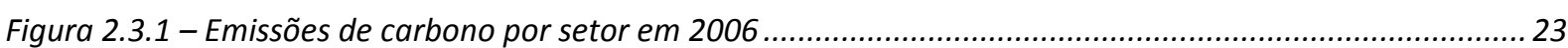

Figura 2.3.2 - Emissões relativas de poluentes por tipo de fontes -2005 ..................................................25

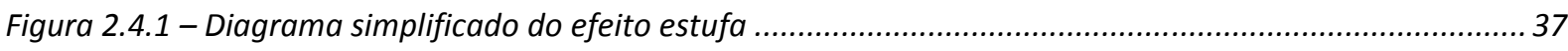

Figura 2.5.1 - O ambiente contaminado e o efeito no corpo humano........................................................... 41

Figura 3.1.1 - Mapa geral do município de São Carlos. Em verde, o trajeto referente a um dos ensaios. ............83

Figura 3.2.1 - Sequência dos procedimentos para realização do trabalho...................................................... 86

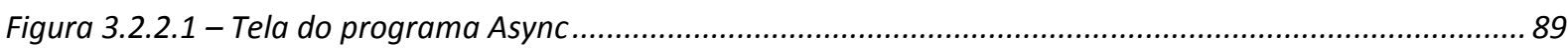

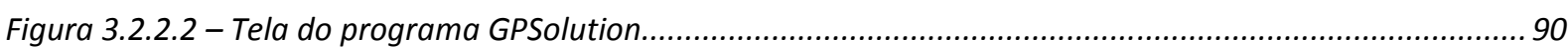

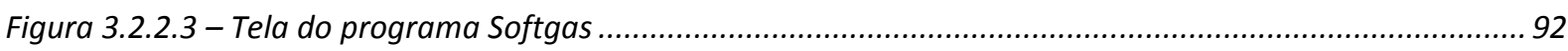

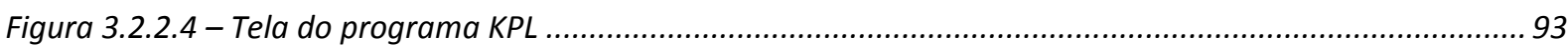

Figura 3.2.2.5 - Resultados do programa KPL para serem exportados para planilha Excel .............................. 93

Figura 3.2.3.1 - Foto do GPS ligado ao notebook e a antena externa ............................................................ 94

Figura 3.2.3.2 - Detalhe da sonda ligado ao escapamento do carro ..............................................................94

Figura 3.2.3.3 - Comprimento da mangueira de teste.................................................................................... 95

Figura 3.2.3.4 - Termopar para medição da temperatura do óleo do motor ....................................................95

Figura 3.2.3.5 - Analisador de gases ligado ao notebook e ao GPS............................................................. 96

Figura 3.3.1 - Tela ilustrativa dos comandos para transformar os dados *.g12 em Rinex................................97

Figura 3.3.2 - Tela do programa Convert32.exe convertendo um arquivo extensão *.gps em Rinex...................98

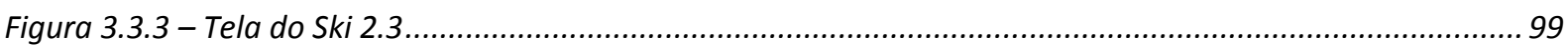

Figura 3.3.4 - Tela de configuração usada no programa Ski 2.3 ....................................................................99

Figura 3.3.5 - Programa SKI 2.3 com os dados inseridos .......................................................................... 101

Figura 3.3.6 - Resultado do processamento do programa SKI 2.3............................................................... 102

Figura 3.3.7 - Programa SKI 2.3 exportando para texto resultado do processamento...................................... 103

Figura 3.3.8 - Programa Excel importando os dados obtidos pelo GPS........................................................ 103

Figura 3.3.9 - Programa SKI 2.3 exportando para formato dxf resultado do processamento GPS.................... 104

Figura 3.3.10 - Tela do programa AutoCAD importando arquivo dxf ............................................................ 105

Figura 3.3.11 - Tela do programa AutoCAD com mapa e caminho percorrido durante o ensaio.......................105

Figura 3.3.12 - Tela do programa SoftGas com gráfico da emissão de gases gerado........................................106

Figura 3.3.13 - Tela do Excel com todos os dados de campo.......................................................................107

Figura 4.1.1 - Foto ilustrativa do Trecho 1 - Rua João Lourenço Rodrigues..................................................... 12

Figura 4.1.2 - Mapa ilustrativo do percurso do veículo no ensaio 316MF no Trecho 1 ....................................113

Figura 4.1.3 - Foto ilustrativa do Trecho 2 - Avenida São Carlos ............................................................... 115

Figura 4.1.4 - Mapa ilustrativo do percurso do veículo no ensaio 316MF no Trecho 2 ....................................116

Figura 4.1.5 - Foto ilustrativa do Trecho 3 - Avenida São Carlos ...................................................................117

Figura 4.1.6 - Mapa ilustrativo do percurso do veículo no ensaio 316MF no Trecho 3 .................................... 118

Figura 4.1.7 - Foto ilustrativa do Trecho 4 - Avenida São Carlos ................................................................ 121

Figura 4.1.8 - Mapa ilustrativo do percurso do veículo no ensaio 316MF no Trecho 4 ....................................122

Figura 4.1.9 - Foto ilustrativa do Trecho 5 - Avenida Trabalhador Sancarlense .............................................124

Figura 4.1.10 - Mapa ilustrativo do percurso do veículo no ensaio 316MF no Trecho 5 .................................. 125 



\section{Lista de tabelas}

Tabela 2.1.1 - Padrões nacionais de qualidade do ar

Tabela 2.2.1 - Escala espacial do fenômeno da química da atmosfera ...........................................................2 21

Tabela 2.3.1 - Contribuição relativa das fontes de poluição do ar na RMSP em 2005 ........................................26

Tabela 2.3.2 - Fatores médios de emissão dos veículos em uso na RMSP em 2005 .......................................... 26

Tabela 2.3.3 - Contribuição relativa das fontes de poluição do ar na RMSP em 2005 .......................................2 27

Tabela 2.5.1 - Tabela de valores de referência de níveis de periculosidade de acordo com a ASHREA................40

Tabela 2.5.2 - Principais poluentes considerados indicadores da qualidade do ar.............................................42

Tabela 2.6.2.1 - Veículos subordinados à inspeção e sua frequência .................................................................48.

Tabela 2.6.2.2 - Comparação das reduções de emissões estimadas pela EPA e levantadas...............................5 51

Tabela 2.6.2.3 - Redução das emissões de poluentes dos programas de I/M da Suécia e da Suíça.....................52

Tabela 2.6.5.1 - Limites máximos de emissão para veículos leves novos .........................................................59

Tabela 2.6.5.2 - Fatores médios de emissão para veículos leves novos............................................................61

Tabela 2.6.5.3 - Média geral da quilometragem anual percorrida pelos veículos................................................64

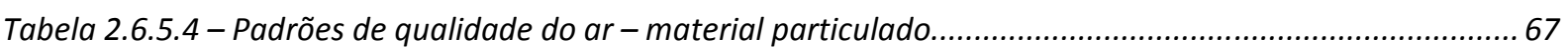

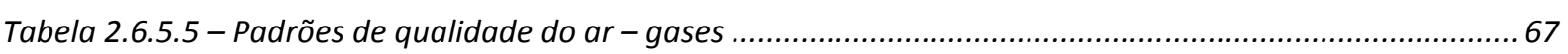

Tabela 2.6.5.6 - Medidas para amenizar a poluição veicular ...............................................................................69

Tabela 2.8.1 - Taxa de emissão para veículos leves á gasolina no programa Dracula ........................................ 78

Tabela 2.8.2 - Fatores de emissão sugeridos por Detran e Feema (2001) ........................................................ 79

Tabela 3.2.2.1 - Tabela das características do analisador de gás TM 132 utilizado...........................................91

Tabela 4.1.1 - Resultados de campo obtidos com motor frio: médias totais dos ensaios no Trecho 1...............113

Tabela 4.1.2 - Resultados de campo obtidos com motor frio: médias totais dos ensaios no Trecho 2...............116

Tabela 4.1.3 - Resultados de campo obtidos com motor frio: médias totais dos ensaios no Trecho 3...............119

Tabela 4.1.4 - Resultados de campo obtidos com motor quente: médias totais dos ensaios no Trecho 3.........120

Tabela 4.1.5 - Resultados de campo obtidos com motor frio: médias totais dos ensaios no Trecho 4................ 122

Tabela 4.1.6 - Resultados de campo obtidos com motor quente: médias totais dos ensaios no Trecho 4......... 123

Tabela 4.1.7 - Resultados de campo obtidos com motor quente: médias totais dos ensaios no trecho 5 ......... 125

Tabela 4.2.2 - Comparação entre os níveis de CO emitidos entre os trecho 3 e 4 ............................................ 143

Tabela 4.2.3 - Comparação entre os níveis de HC emitidos entre os trecho 3 e 4 ........................................... 149

Tabela 4.3.1 - Média ponderada de todos os trechos analisados ................................................................ 162 



\section{Lista de gráficos}

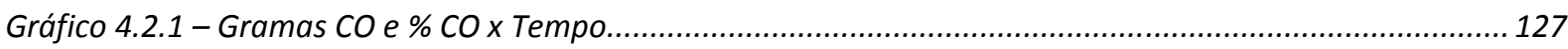

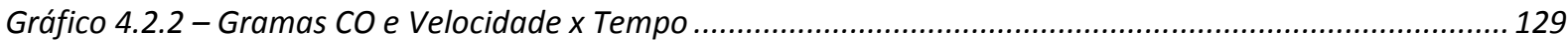

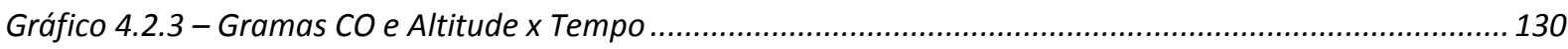

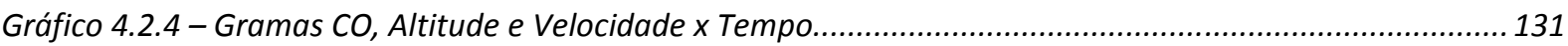

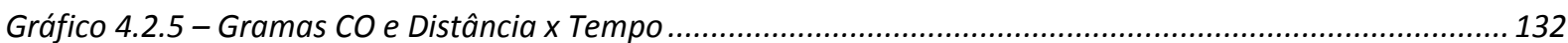

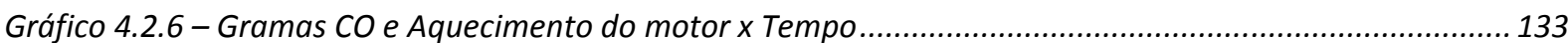

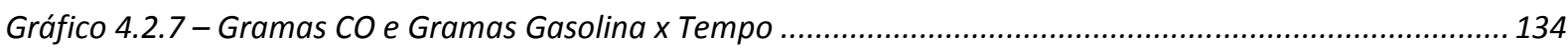

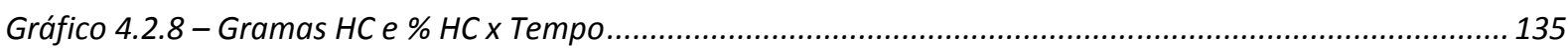

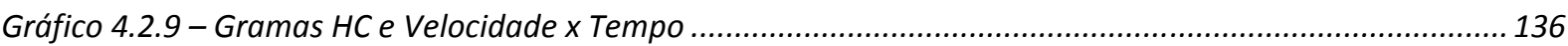

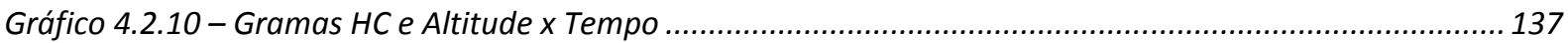

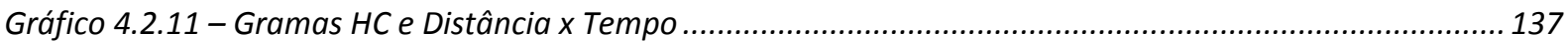

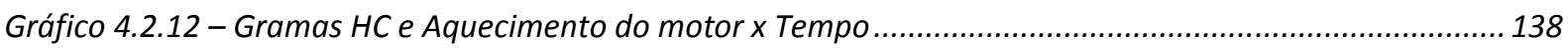

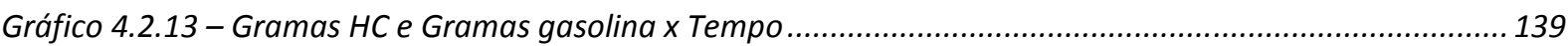

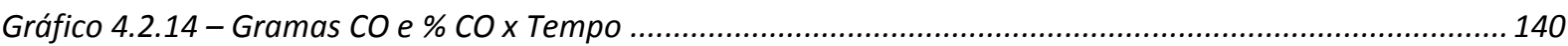

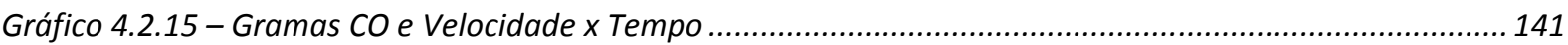

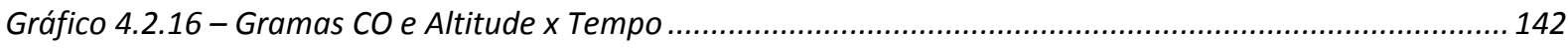

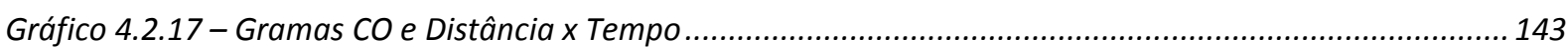

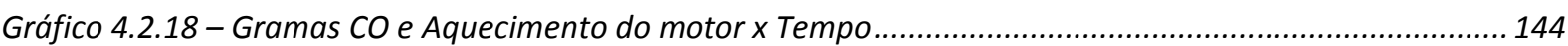

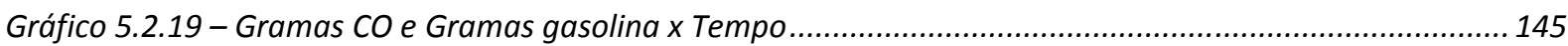

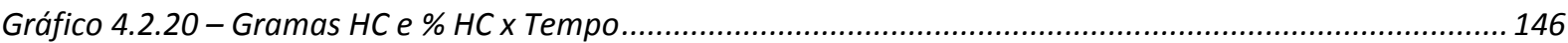

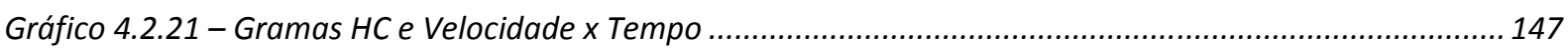

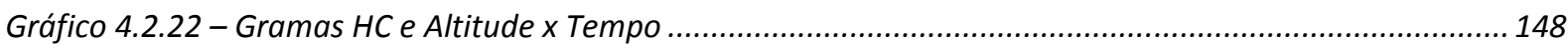

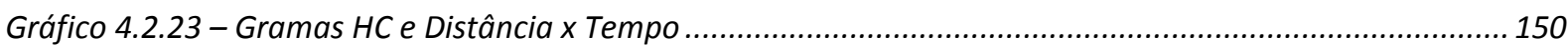

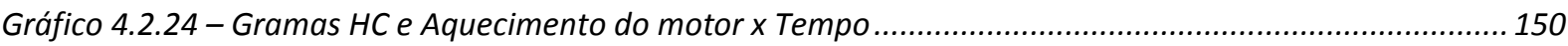

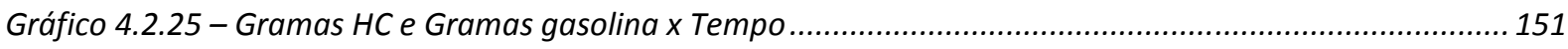

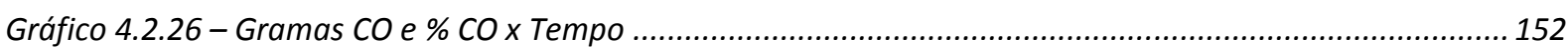

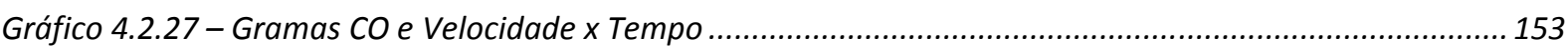

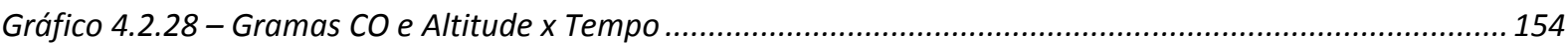

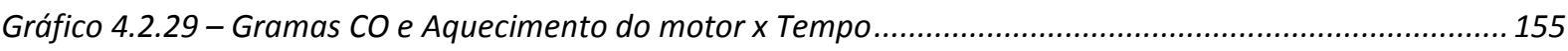

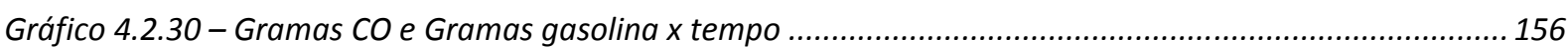

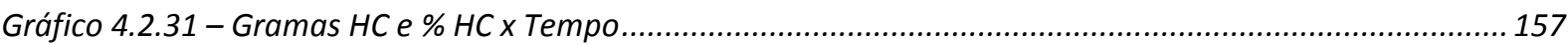

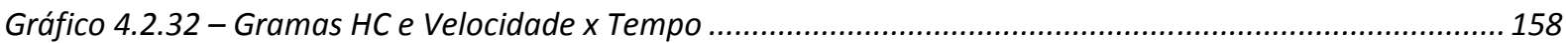

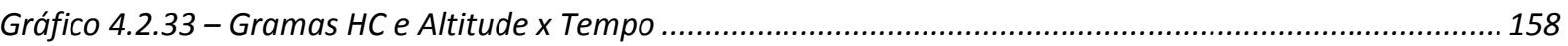

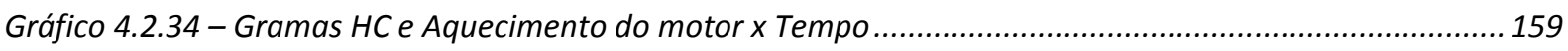

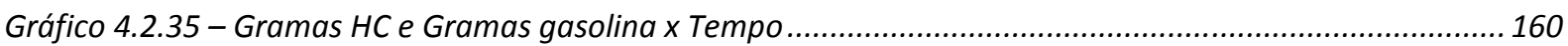





\section{Lista de equações}

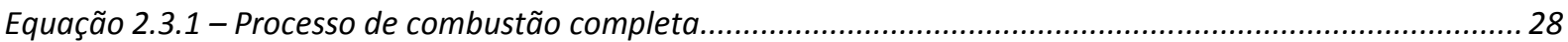

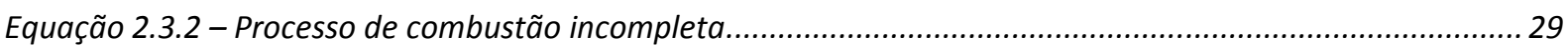

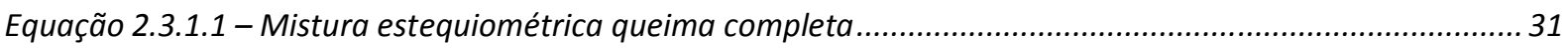

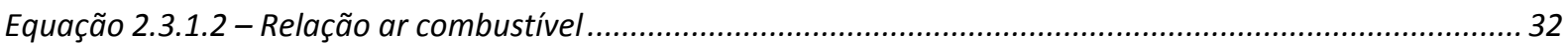

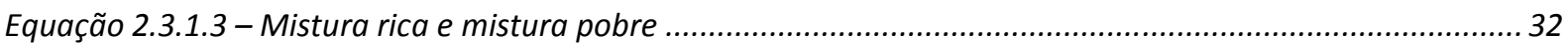

Equação 2.3.1.4 - Fórmula para determinação do poder calorífico aproximado dos combustíveis..................... 33

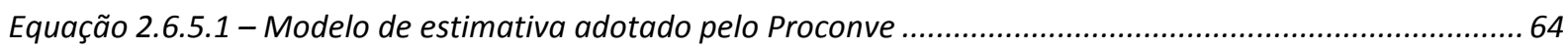

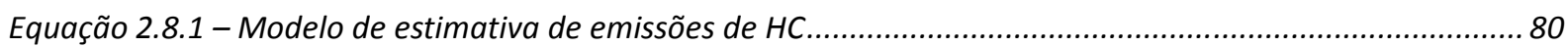

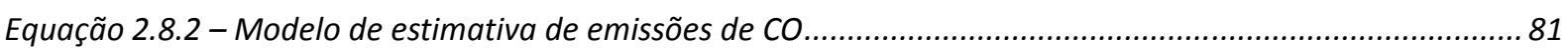

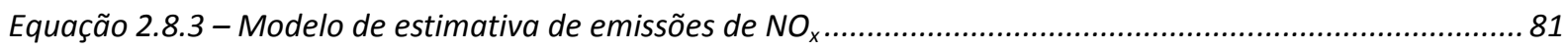





\section{SUMÁRIO}

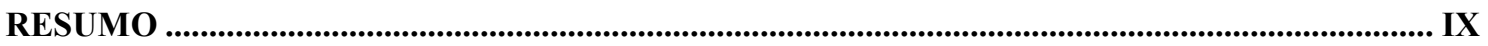

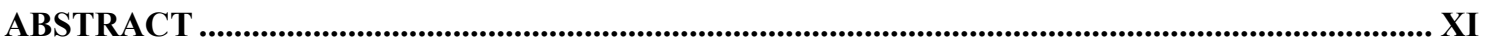

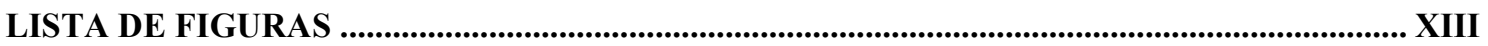

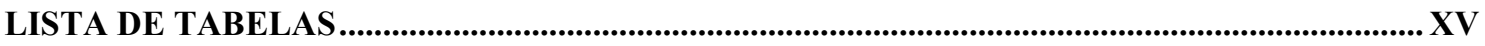

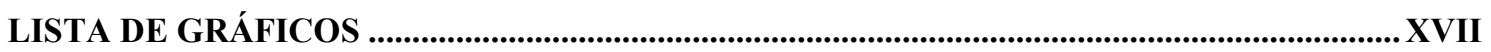

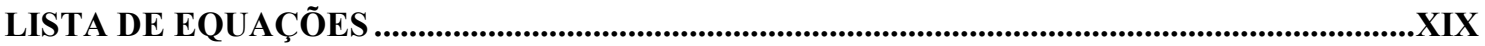

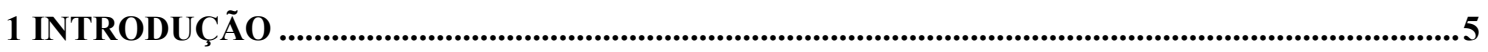

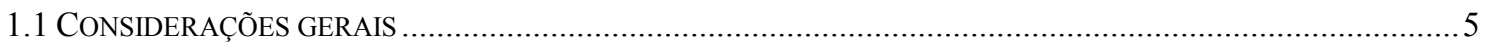

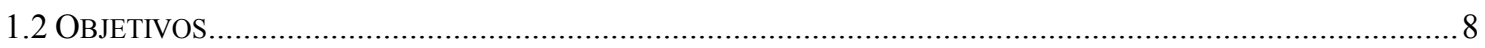

1.3 HIPÓTESES.

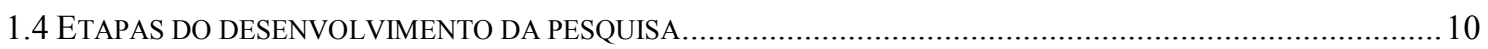

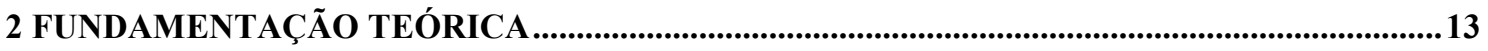

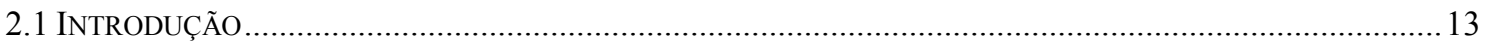

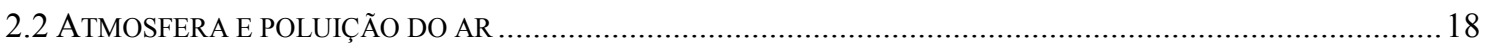

2.3 EMISSÕES DE GASES POR VEÍCULOS AUTOMOTORES ...........................................................................24

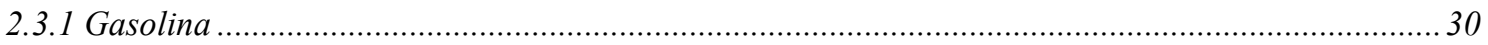

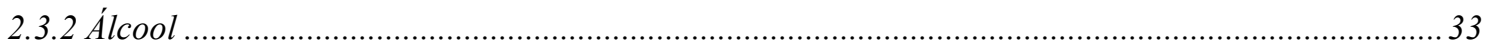

2.4 GERAÇÃO, DISPERSÃO E CONSEQUÊNCIAS DE POLUENTES EM ESCALA URBANA ......................................... 36

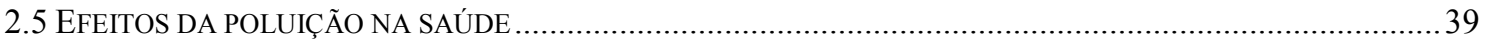

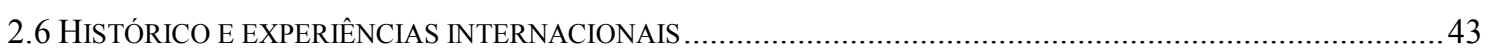

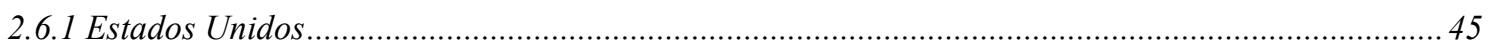

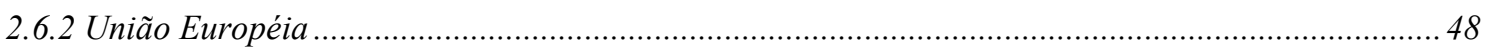

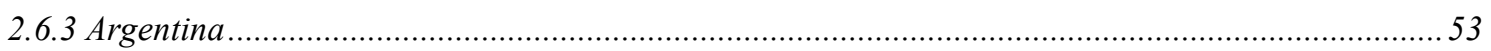

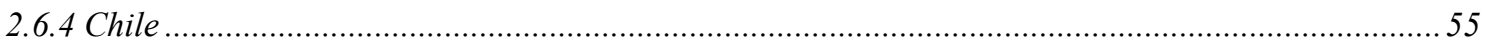

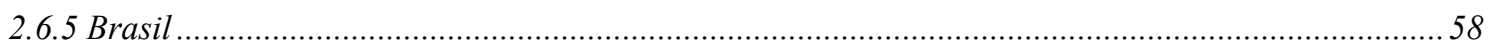

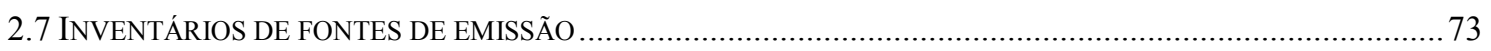

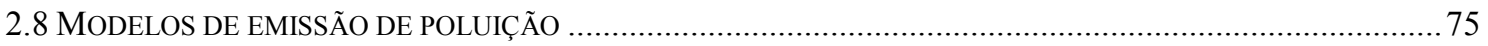


3 EXPERIMENTAL

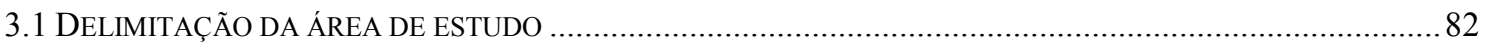

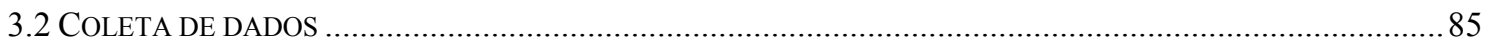

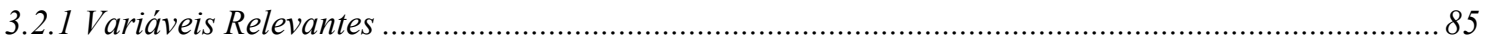

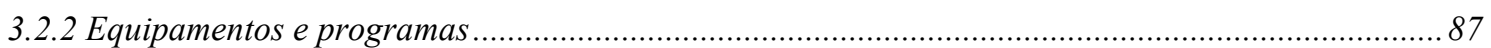

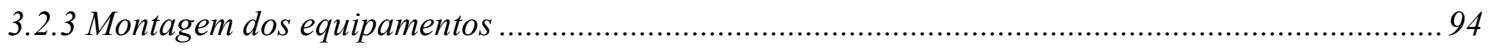

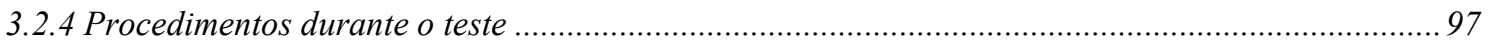

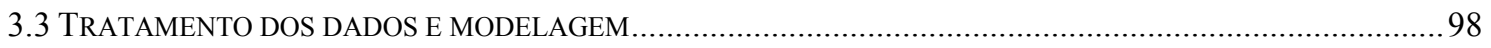

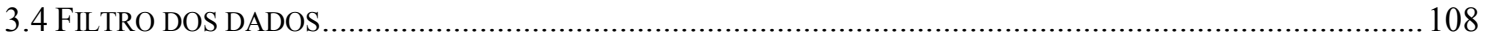

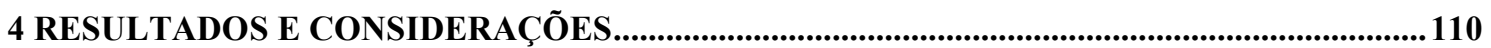

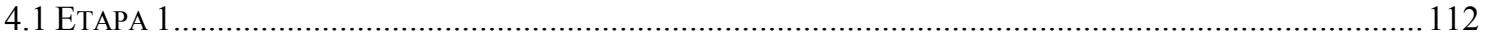

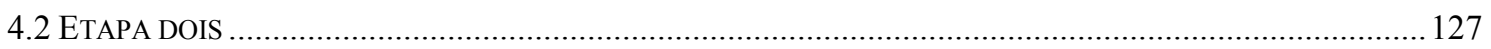

4.2.1 Análise da emissão de CO com o motor frio ............................................................................... 128

4.2.2 Análise da emissão de HC com o motor frio ..................................................................... 135

4.2.3 Análise da emissão de CO com o motor quente ....................................................................... 140

4.2.4 Análise da emissão de HC com o motor quente ................................................................... 147

4.2.5 Análise da emissão de CO com o motor quente no trecho 5 ................................................... 152

4.2.6 Análise da emissão de HC com o motor quente no trecho 5 ....................................................... 157

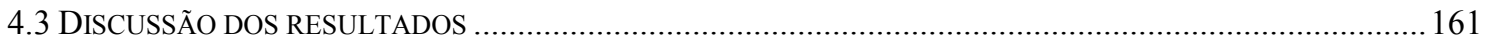

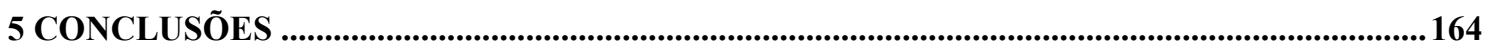

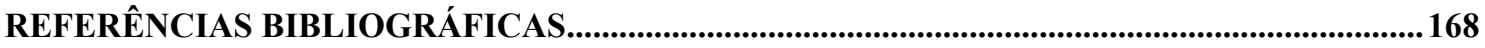

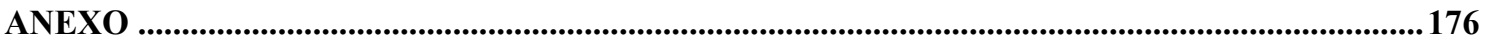

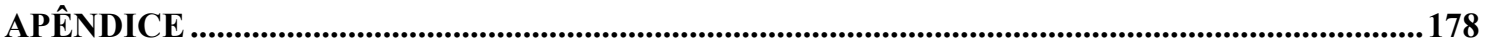




\section{INTRODUÇÃO}

\subsection{Considerações gerais}

Os níveis de poluição vivenciados atualmente na maioria das cidades são suficientes para causar agravos à saúde da população. Segundo Gouveia et al. (2002), existem associações estatisticamente significantes entre o

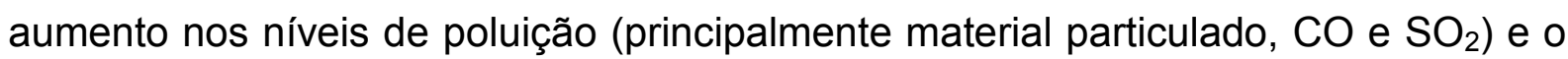
aumento na mortalidade e nas hospitalizações, por causas respiratórias e cardiovasculares, em crianças e idosos.

A fim de elucidar ainda mais a magnitude do problema, é válido citar que a Organização Mundial de Saúde (OMS) estima, em termos mundiais, que mais de 1,4 bilhões de residentes das áreas urbanas respiram ar que excedem negativamente os padrões atuais de qualidade (WRI, 1999); e que de acordo com Delucchi (2004), os veículos automotores nos Estados Unidos geram custos relacionados aos danos à saúde, na ordem de US\$30 a US\$560 bilhões ao ano.

$\mathrm{O}$ aquecimento global e suas consequências climáticas têm dado origem a muitas discussões e têm sido alvo de muitas pesquisas. A maioria dos pesquisadores que compuseram o IPCC (Painel Intergovernamental sobre Mudanças Climáticas), órgão da ONU (Organização das Nações Unidas) destinado a estudar as mudanças climáticas no planeta, afirma categoricamente que as mudanças climáticas atuais ocorrem principalmente por causas antropogênicas, isto é, poluição gerada pela queima de combustíveis fósseis, desmatamentos etc. (MENDES, 2004). Por outro lado, outros cientistas defendem o modelo heliogênico, uma vez que o planeta já passou por aquecimentos em épocas anteriores, isto é, o aquecimento global estaria ocorrendo por causa natural, por exemplo, pelo aumento da atividade magnética do sol (LOMBORG, 2008). No entanto, todos concordam que a poluição gerada está contribuindo, de uma forma ou de outra, para a degradação da qualidade de vidas das pessoas.

O transporte de bens e pessoas é fundamental para a integração das regiões do país proporcionando o desenvolvimento econômico e social. Para que isso ocorra, é preciso alocar recursos para a construção e a 
manutenção da infra-estrutura dos modos de transporte, bem como prever a energia necessária para a movimentação dos veículos. Essas ações devem, no entanto, levar sempre em conta as questões ambientais, o que normalmente é negligenciado pelos poderes públicos.

O número de veículos automotores em circulação no Brasil vem crescendo significativamente nas últimas décadas gerando um aumento na quantidade de gases poluentes emitidos. Segundo Gouveia et al. (2002) já está comprovado que essa emissão contribui muito para a degradação da qualidade de vida das pessoas que vivem em locais onde a concentração de emissões veiculares é intensa.

Por volta da década de 1940 , as cidades começaram a ter maior número de pessoas, advindas da área rural. Segundo o Instituto Brasileiro de Geografia e Estatística - IBGE (2008), a porcentagem de população urbana ${ }^{1}$ passou de $30,24 \%$ na década de 1940 para $81,23 \%$ em 2000. Com isso, ocorreu um aumento tanto na poluição gerada nas cidades como no número de pessoas atingidas por essa poluição, o que passou a interferir diretamente na saúde e, por conseguinte, na qualidade de vida das pessoas.

Quando se discute a emissão de gases nocivos à saúde humana, emitidos por veículos automotores, a principal referência que se estabelece é com as grandes cidades, volumosos congestionamentos, grande número de veículos, deslocamentos que podem levar horas e, em regra, essas consequências, no que diz respeito à exposição à poluição, são menosprezadas no que se refere às cidades pequenas e médias.

Segundo IBGE (2008), são chamadas cidades médias aquelas cuja população varia entre 100 mil e 500 mil habitantes. Consideram-se cidades pequenas aquelas com população inferior a 100 mil habitantes. Esses são os parâmetros tomados como fundamentais para esta pesquisa.

No Brasil, as cidades pequenas e médias constituem $73,26 \%$ do total (de 5.564 municípios, 4.074 são considerados pequenos e médios, segundo dados do IBGE (2008). Assim, tendo em vista a grande quantidade de pessoas envolvidas nesse contexto (cerca de $67 \%$ da população brasileira), é necessário que

\footnotetext{
${ }^{1}$ No Brasil, o critério de determinação de espaços urbanos se fundamenta em decisões políticoadministrativas, com base no Decreto-Lei 311/38. As áreas urbanas são definidas pelo próprio município, por meio de lei municipal.
} 
se estudem os fenômenos ligados à emissão de gases poluentes não apenas nos grandes centros urbanos.

Em regra, a variação na quantidade de emissão de poluentes pelos veículos automotores não tem relação direta com o tamanho da cidade em que se encontram. Deve-se ressaltar, entretanto, que os inventários e modelos de emissão em regra fundamentam seus parâmetros em valores obtidos quando o conjunto motor/catalisador já está aquecido, o que não chega a acontecer no contexto que ora se propõe a estudar. Eis que, se se aplicarem indistintamente os parâmetros daqueles modelos aos veículos utilizados em cidades pequenas e médias, onde os trajetos são, em regra, curtos, e, portanto, o veículo trafega frio, podem ocorrer imprecisões.

Segundo Jacondino e Cybis (2003), os fatores de emissão de poluentes utilizados para cada localidade deveriam ser baseados em medições das taxas de emissão de poluentes dos veículos na área de estudo. A obtenção de medidas confiáveis de fatores de emissão, entretanto, é um processo complexo e, portanto, de custo elevado. Em razão disso, poucos experimentos são realizados. Geralmente poucos veículos são testados, e quando o são, o teste ocorre sob condições bastante limitadas, seja em laboratório seja em condições reais de tráfego. Nota-se também que pouca ou nenhuma atenção se dá à forma como os veículos são conduzidos, seja devido à ação do motorista, seja devido às obstruções naturais e artificiais colocadas para controlar esta ação.

Além disso, conforme os mesmos autores, os modelos de previsão de emissão e acúmulo de poluentes em geral são baseados em modelos gerados por simulações que não incluem dados provenientes de mensuração realizada diretamente nos locais de estudo. Com isso, a solução encontrada para gerar modelos de previsão de emissão e acúmulo de poluentes se baseia em parâmetros construídos a partir de simulações que não incluem dados provenientes de mensuração real, como a que se propõe neste trabalho.

Assim, encontrar uma maneira de se mensurar a real emissão de gases pelos veículos automotores, para que seja possível criar políticas públicas de modo que essa emissão seja reduzida, é, não somente, interessante, mas também desejável, uma vez que o problema tende a se tornar crônico. Tendo em vista as especificidades do combustível e de outros fatores característicos nacionais, não é possível que se utilizem dados internacionais para que se fundamente uma 
normatização nacional. Portanto, justifica-se uma investigação mais atenta desses parâmetros, principalmente quanto à emissão inicial, em que o conjunto motor/catalisador ainda não se aqueceu. Essa situação é pouco estudada e muitas vezes até deixa de ser computada em inventários e modelos de emissões de gases poluentes. Também pouco se atenta a outros fatores, como a topografia acidentada, a pavimentação das vias de trânsito, e outras causas que reduzem obrigatoriamente a velocidade dos veículos.

Há algumas décadas, grande parte dos ensaios era feita em condições laboratoriais, pois era muito difícil mensurar a emissão de gases poluidores em tempo real, nas condições normais de uso. Com o passar dos anos, surgiram tecnologias como o GPS e analisadores de gases portáteis, que se tornaram equipamentos confiáveis, de preço acessível e de uso simplificado. Com esses equipamentos portáteis, cuja coleta de dados é confiável, é possível ensaiar um veículo automotor em situação real de uso, ou seja, um veículo de uso comum, trafegando por vias ordinárias, com todos os problemas que se encontram normalmente no trânsito das cidades (superfícies das vias em condições não ideais, trânsito lento, obstáculos, etc.) e outras relativas ao próprio veículo, como temperatura do conjunto motor/catalisador, inclinação das vias, etc.

Com a medição real e efetiva da emissão dos gases gerados pelos veículos automotores, podem-se obter dados mais precisos que contribuam para tornar esses modelos mais eficientes. A proposta deste trabalho é aproveitar as inovações tecnológicas do último século, como GPS e analisadores de gases, para, de fato, se chegar a mensurar essa emissão de gases o mais próximo do real.

Assim, com base no que ora se propõe, é possível desenvolver procedimentos e metodologias de modo que a coleta de dados possa oferecer informações mais realistas para se fazer inventários de emissão de gases e aperfeiçoar modelos de emissão de gases poluentes emitidos por veículos automotores.

\subsection{Objetivos}

O objetivo principal do trabalho é desenvolver uma metodologia para mensurar, em tempo e condições reais, os parâmetros usados em inventários e 
modelos de estimativa de emissões de gases poluentes gerados por veículos automotores, particularmente em meio urbano, em cidades pequenas e médias, com o conjunto motor/catalisador ainda frio.

Dessa forma, indicadores de poluição de gases emitidos por veículos automotores, dentro das características da região onde se faz o percurso, podem ser calculados de forma mais realista. Os dados, por serem obtidos de forma simplificada, objetiva e direta, ocasionam uma diminuição na imprecisão dos cálculos utilizados normalmente. Assim, não se pretende desenvolver um novo modelo de emissão de poluentes, mas debater sobre os já existentes, utilizando novas tecnologias, simplificando e aperfeiçoando muitas das medições utilizadas nos modelos tomados, com particular atenção nas medições de emissão de $\mathrm{CO}$ e HC em trajetos curtos e motor frio em meio urbano.

\subsection{Hipóteses}

Os modelos atuais de mensuração de emissão de poluentes por veículos automotores, usados em inventários, fundamentam-se em valores obtidos em ensaios padrões e não a partir de uma situação real de uso. Dessa forma, algumas informações e parâmetros importantes recebem menos atenção ou até mesmo são desconsiderados. Em geral, no que se refere à emissão de gases, os parâmetros se baseiam no motor quente, quando na realidade, até o motor aquecer, a taxa de emissão dos gases poluidores pode ser muito diferente da considerada. Essa diferença acaba por ser desconsiderada, o que gera distorções na aplicação dos modelos a situações diversas de trânsito.

Cada trecho do deslocamento de um veículo automotor tem suas características específicas como inclinações, intensidade de tráfego, dentre outros, que influenciam diretamente na emissão dos gases. Hoje é possível, por meio de novas tecnologias, mesmo que de forma simplificada, considerar mais parâmetros para representar a emissão de poluição. É importante, portanto, levar em consideração mais detalhes para o aperfeiçoamento da mensuração dessas emissões. 
Assim, a hipótese de trabalho é que os modelos existentes para a mensuração da emissão de $\mathrm{CO}$ e de $\mathrm{HC}$ não são suficientemente completos quando se trata de mensurar essa emissão em trajetos curtos com motor a frio.

\subsection{Etapas do desenvolvimento da pesquisa}

O trabalho foi estruturado em três etapas principais:

A) Etapa 1 - Pesquisa Bibliográfica

- Levantamento bibliográfico relativo à atmosfera e à poluição do ar, à emissão de gases por veículos automotores, assim como à sua dispersão, consequências e efeitos sobre a saúde.

- Levantamento bibliográfico relativo às experiências nacionais e internacionais para reduzir essas emissões de gases e poluição.

- Levantamento bibliográfico relativo a inventários de fontes de emissões, modelos matemáticos e programas que auxiliam a elaboração de inventários de emissões.

B) Etapa 2 - Métodos adotados na coleta de dados

- Pesquisas de métodos de seleção e coleta de dados, relativos ao problema, de forma adequada para que se proceda a uma análise qualitativa e quantitativa. Esta pesquisa tem um caráter nacional, visto que os veículos no Brasil utilizam um combustível totalmente diferenciado de outros países, conforme restará esclarecido no decorrer do trabalho.

- Coletar dados como perfil de velocidade, trajeto do veículo e detalhes topográficos, por meio do Sistema de Posicionamento Global - GPS;

- Coletar, por meio de um analisador de gases, os gases emitidos e analisar esses dados em comparação com os dados obtidos a partir da aplicação dos modelos levantados a partir da bibliografia;

- Mensurar, por meio do computador de bordo do próprio veículo, o consumo instantâneo, a partir do que se pode mensurar qual a emissão de $\mathrm{CO}$ e $\mathrm{HC}$ pelo veículo nas condições simuladas, em situações mais reais. Os dados obtidos 
serão comparados, ao final do trabalho, com os dados estatísticos de órgãos governamentais que fundamentam as políticas públicas a respeito.

C) Etapa 3 - Apresentação dos resultados e dos parâmetros mais adequados a serem aplicados em modelos de estimativa de emissões para o estudo de caso.

- Os dados obtidos fornecem parâmetros que permitem, entre outras coisas, avaliar a situação ambiental da região sob alguns aspectos importantes. Em particular, essa metodologia (modelo e métodos de campo) poderá ser utilizada para verificar a formação de ilhas de calor urbano ou prever o nível de poluentes em determinadas regiões. Esses parâmetros, portanto, são particularmente úteis para subsidiar decisões de planejamento urbano e de saúde ambiental garantindo qualidade na prestação desses serviços.

O presente trabalho está estruturado em cinco capítulos. O primeiro apresenta uma introdução, com uma discussão básica dos elementos justificadores da pesquisa.

O Capítulo 2 traz uma revisão da literatura existente sobre poluição atmosférica, geração e dispersão de poluentes em escala urbana e seus efeitos na saúde humana, inventários de fontes de emissão de gases poluentes. Há, ainda, um histórico do estudo da emissão de gases em vários países e da forma como internacionalmente o problema é tratado. Apresenta também alguns modelos de emissão existentes.

No Capítulo 3, estão descritas todas as informações a respeito dos dados coletados durante a pesquisa: a forma de coleta desses dados, os equipamentos e programas usados, a forma de tratamento e de filtragem desses dados.

O Capítulo 4 traz os resultados obtidos a partir da aplicação da metodologia desenvolvida no capítulo anterior aos ensaios realizados com o veículo, com o motor frio e com o motor quente. Esses resultados estão divididos em tabelas de médias globais obtidas em todos os ensaios. Também são apresentados detalhadamente os dados obtidos em um ensaio prototípico.

O último capítulo apresenta as conclusões a que se chegou a partir da análise dos dados obtidos e sugestões para que esses dados alimentem a produção de novas pesquisas. 
Ao final do trabalho, está apresentada, sob a forma de anexo, a análise realizada com o combustível utilizado no veículo durante os ensaios. Encontra-se também um apêndice com os dados obtidos no ensaio do dia 316 pela manhã, com o motor frio e com o motor quente (ensaio tomado como prototípico para o desenvolvimento da chamada Etapa 2 dos Resultados). 


\section{FUNDAMENTAÇÃO TEÓRICA}

Este capítulo traz um resumo da literatura existente sobre a poluição atmosférica produzida por veículos automotores, os efeitos gerais da poluição do ar nas cidades e as políticas e estratégias que são usadas para medição e controle das emissões veiculares, abrangendo um histórico das ações tomadas em vários países.

\subsection{Introdução}

O aumento significativo de pessoas vivendo em áreas urbanas gera maior demanda de transporte e quantidade de bens sendo transportados nestas áreas, percorrendo distâncias variadas. A consequência dessa urbanização é o constante aumento da frota de veículos automotores em uso nas cidades. Como em geral, em nosso país, não há priorização ao transporte público coletivo, este aumento de frota é ainda maior devido ao crescimento, ainda mais acentuado, dos meios de transporte individuais.

Segundo a Fundação Sistema Estadual de Análise de Dados Seade (2007), a frota de veículos no estado de São Paulo cresceu quatro vezes mais do que a população entre os anos 2002 e 2006. Desde 2002, o estado teve um aumento de $26 \%$ no número de veículos. No ano de 2006 , a cidade de Ribeirão Preto registrou 1,96 habitantes por veículos e São Carlos 2,27 habitantes por veículo.

Como a emissão de gases poluentes dos veículos automotores degrada a qualidade do ar e é, portanto, prejudicial ao bem estar e à saúde da população, é evidente que esse aumento da frota é fundamental dentro do contexto ambiental. Em termos gerais, pode-se afirmar que, nos grandes centros populacionais do país, os veículos automotores, fonte bastante significativa de emissão de contaminantes do ar, contribuem muito para a baixa qualidade de vida das pessoas.

Segundo dados da European Environment Agency - EEA (2002), a maior parte dos derivados de petróleo consumidos no mundo destina-se ao 
setor de transportes. Embora existam fontes alternativas, com tecnologias desenvolvidas para obtenção e utilização de energia em transportes, os fatores econômicos prevalecem, uma vez que, se não se levar em conta o custo ambiental, a energia gerada através da combustão de derivados de petróleo é, na maioria das vezes, mais econômica, enquanto matriz energética, visto que os custos para produção e transporte de outras fontes de energia são mais altos.

As fontes de energia baseadas no carbono sofrem combustão para geração de energia. Essa conversão de energia pode gerar calor e movimento para os veículos. O resíduo dessa combustão volta para a atmosfera, gerando, quando em demasia, os problemas ambientais. A figura 2.1.1 ilustra esse processo:

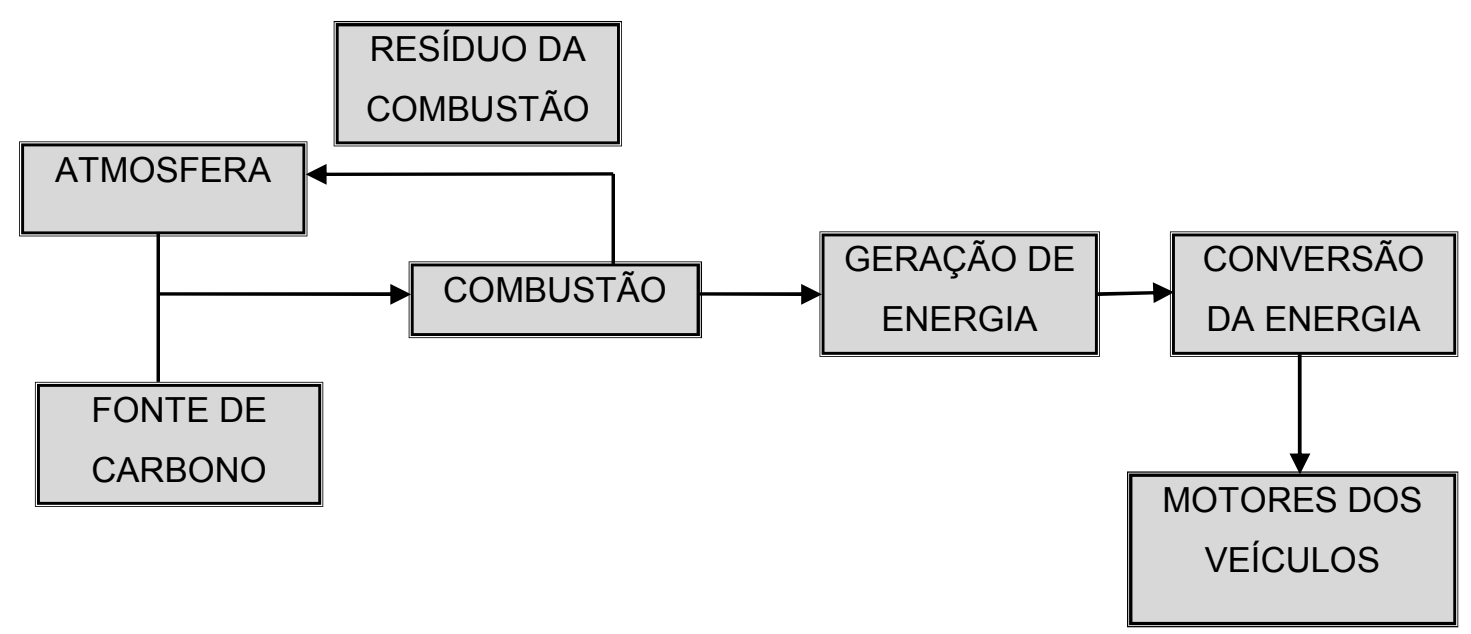

Figura 2.1.1 - Esquema simplificado da utilização da energia dos combustíveis fósseis nos transportes

Entre os consumidores de petróleo, os segmentos mais importantes são o de transportes e o das indústrias. A estrutura de usos dos derivados do petróleo passou por significativas variações. A figura 2.1.2 a seguir mostra que o setor de transportes só perde para a indústria em gastos energéticos por ano. É possível notar também como vem aumentando o consumo de energia com o passar dos anos, mesmo com o desenvolvimento tecnológico e equipamentos cada vez mais eficientes e econômicos. Muitos desses gastos poderiam ser reduzidos com políticas públicas e conscientização do uso racional da energia. 


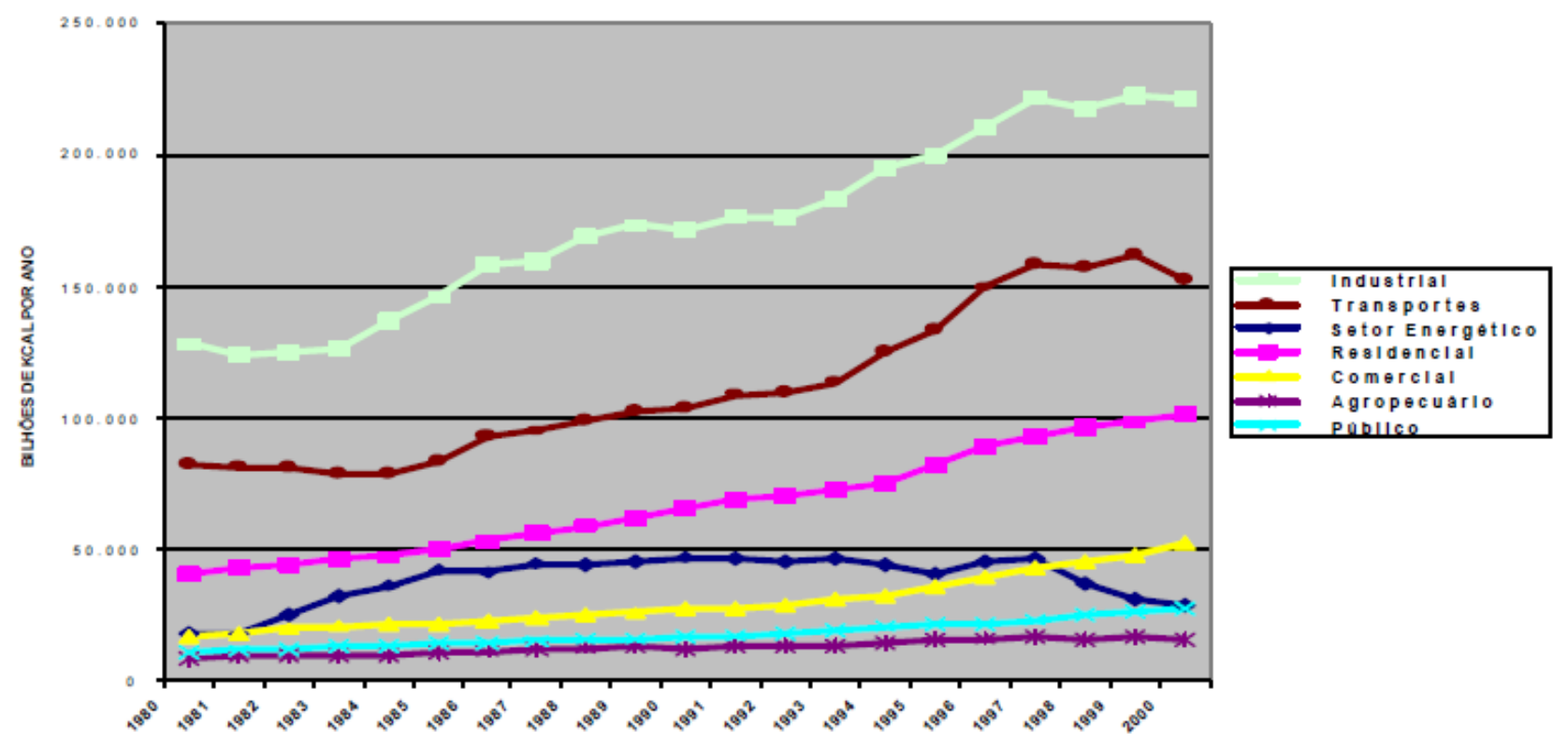

Figura 2.1.2 - Consumo de energia por setores finais em São Paulo (trilhões de Kcal/ano) Fonte - Cetesb (2008)

A variedade de substâncias que podem estar presentes na atmosfera, em uma determinada região, é muito grande. Quando se determina a concentração de um poluente na atmosfera, mede-se o grau de exposição dos receptores (seres humanos, outros animais, plantas, materiais) como resultado final do processo de lançamento deste poluente na atmosfera, a partir de suas fontes de emissão e suas interações na atmosfera, do ponto de vista físico (diluição) e químico (reações químicas).

O sistema pode ser visualizado da seguinte forma:

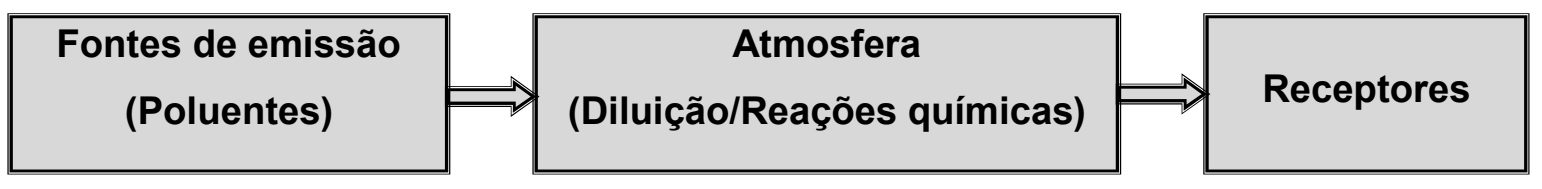

Figura 2.1.3 - A influência dos poluentes nos receptores

É importante frisar que, mesmo mantidas as emissões constantes, a qualidade do ar pode mudar em função das condições meteorológicas que determinam uma maior ou menor diluição dos poluentes. É por isso que a qualidade do ar piora durante os meses de inverno, quando as condições meteorológicas são mais desfavoráveis à dispersão dos poluentes. Já em relação à formação do ozônio, este poluente apresenta maiores concentrações na primavera e no verão, devido à maior intensidade da luz solar. A interação entre as fontes de 
poluição e a atmosfera vai definir o nível de qualidade do ar, que determina, por sua vez, o surgimento de efeitos adversos da poluição do ar sobre os receptores.

No processo de determinação da qualidade do ar, sistematicamente limita-se o número de poluentes em estudo, em função de sua importância e dos recursos materiais e humanos disponíveis. Os mais importantes grupos de poluentes que servem como indicadores de qualidade do ar são: dióxido de enxofre $\left(\mathrm{SO}_{2}\right)$, material particulado (MP), monóxido de carbono $(\mathrm{CO})$, ozônio $\left(\mathrm{O}_{3}\right)$ e dióxido de nitrogênio $\left(\mathrm{NO}_{2}\right)$. A razão da escolha desses parâmetros como indicadores de qualidade do ar estão ligados às suas maiores frequências de ocorrência e aos efeitos adversos que causam ao meio ambiente (SÃO PAULO (Estado), 2006).

Um padrão de qualidade do ar (PQAR) define legalmente o limite máximo para a concentração de um componente atmosférico que garanta a proteção da saúde e do bem estar das pessoas. Os padrões de qualidade do ar são baseados em estudos científicos dos efeitos produzidos por poluentes específicos e são fixados em níveis que possam propiciar uma margem de segurança adequada.

Através da Portaria Normativa $n^{\circ} 348$, de 14.03.90, o Instituto Brasileiro do Meio Ambiente e de Recursos Naturais Renováveis - Ibama, estabeleceu os padrões nacionais de qualidade do ar e os respectivos métodos de referência, ampliando o número de parâmetros anteriormente regulamentados por meio da Portaria GM 0231, de 27.04.76. Os padrões estabelecidos através dessa portaria foram submetidos ao Conselho Nacional do Meio Ambiente - Conama, em 28.06.90 e transformados na Resolução Conama n 03/90.

São estabelecidos dois tipos de padrões de qualidade do ar: os primários e os secundários.

São padrões primários de qualidade do ar as concentrações de poluentes que, ultrapassadas, poderão afetar a saúde da população. Podem ser entendidos como níveis máximos toleráveis de concentração de poluentes atmosféricos, constituindo-se em metas de curto e médio prazo.

São padrões secundários de qualidade do ar as concentrações de poluentes atmosféricos abaixo das quais se prevê o mínimo efeito adverso sobre o bem estar da população, assim como o mínimo dano à fauna e à flora, aos materiais e ao meio ambiente em geral. Podem ser entendidos como níveis desejados de concentração de poluentes, constituindo-se em meta de longo prazo. 
O objetivo do estabelecimento de padrões secundários é criar uma base para uma política de prevenção da degradação da qualidade do ar. Devem ser aplicados às áreas de preservação (por exemplo: parques nacionais, áreas de proteção ambiental, estâncias turísticas etc.). Não se aplicam, pelo menos em curto prazo, a áreas de desenvolvimento, onde devem ser aplicados os padrões primários. Como prevê a própria Resolução Conama no 03/90, a aplicação diferenciada de padrões primários e secundários requer que o território nacional seja dividido em classes I, II e III, conforme o uso pretendido. A mesma resolução prevê ainda que, enquanto não for estabelecida a classificação das áreas, os padrões aplicáveis serão os primários.

Os parâmetros regulamentados são os seguintes: partículas totais em suspensão, fumaça, partículas inaláveis, dióxido de enxofre, monóxido de carbono, ozônio e dióxido de nitrogênio. Os padrões nacionais de qualidade do ar estão fixados na Resolução Conama $n^{\circ} 03$ de 28.06.90, apresentados na tabela 2.1.1 a seguir.

Tabela 2.1.1 - Padrões nacionais de qualidade do ar

\begin{tabular}{|c|c|c|c|c|}
\hline Poluente & $\begin{array}{c}\text { Tempo de } \\
\text { Amostragem }\end{array}$ & $\begin{array}{c}\text { Padrão } \\
\text { Primário } \\
\left(\mu g / \mathrm{m}^{3}\right)\end{array}$ & $\begin{array}{c}\text { Padrão } \\
\text { Secundário } \\
\left(\mu \mathrm{g} / \mathrm{m}^{3}\right)\end{array}$ & Método de Medição \\
\hline $\begin{array}{l}\text { Partículas totais } \\
\text { em Suspensão }\end{array}$ & $\begin{array}{l}24 \text { horas }^{1} \\
\text { MGA }^{2}\end{array}$ & $\begin{array}{c}240 \\
80\end{array}$ & $\begin{array}{c}150 \\
60\end{array}$ & $\begin{array}{l}\text { Amostrador de } \\
\text { grandes volumes }\end{array}$ \\
\hline $\begin{array}{l}\text { Partículas } \\
\text { inaláveis }\end{array}$ & $\begin{array}{l}24 \text { horas }^{1} \\
\text { MAA }^{3}\end{array}$ & $\begin{array}{c}150 \\
50\end{array}$ & $\begin{array}{c}150 \\
50\end{array}$ & $\begin{array}{c}\text { Separação } \\
\text { inercial/filtração }\end{array}$ \\
\hline Fumaça & $\begin{array}{l}24 \text { horas }^{1} \\
\text { MAA }^{3}\end{array}$ & $\begin{array}{c}150 \\
60\end{array}$ & $\begin{array}{c}100 \\
40\end{array}$ & Refletância \\
\hline Dióxido de enxofre & $\begin{array}{l}24 \text { horas }^{1} \\
\text { MAA }^{3}\end{array}$ & $\begin{array}{c}365 \\
80\end{array}$ & $\begin{array}{c}100 \\
40\end{array}$ & Pararosanilina \\
\hline $\begin{array}{l}\text { Dióxido de } \\
\text { nitrogênio }\end{array}$ & $\begin{array}{l}1 \text { hora }^{1} \\
\text { MAA }^{3}\end{array}$ & $\begin{array}{l}320 \\
100\end{array}$ & $\begin{array}{l}190 \\
100\end{array}$ & Quimiluminescência \\
\hline $\begin{array}{l}\text { Monóxido de } \\
\text { carbono }\end{array}$ & $\begin{array}{l}1 \text { hora }^{1} \\
8 \text { hora }^{1}\end{array}$ & $\begin{array}{c}40.000 \\
35 p p m \\
10.000 \\
9 p p m\end{array}$ & $\begin{array}{c}40.000 \\
35 p p m \\
10.000 \\
9 p p m\end{array}$ & $\begin{array}{l}\text { Infravermelho não } \\
\text { dispersivo }\end{array}$ \\
\hline Ozônio & 1 hora $^{1}$ & 160 & 160 & Quimiluminescência \\
\hline
\end{tabular}

1 - Não deve ser excedido mais que uma vez no ano

2 - Média geométrica anual

3 - Média aritmética anual

Fonte - Conama (1990a) 


\subsection{Atmosfera e poluição do ar}

A atmosfera da Terra é formada por componentes sólidos, líquidos e gasosos. Segundo Seinfeld e Pandis (2006), a parte gasosa é composta basicamente por $21 \%$ de oxigênio em volume seco de ar, aproximadamente $78 \%$ de nitrogênio e o restante por uma grande variedade de outros gases. Esses gases, embora apresentem concentrações pequenas, às vezes menos que algumas partes por bilhões em volume ( $\mathrm{ppb}$ ), têm um papel muito importante na manutenção da vida e no estabelecimento do clima do planeta. As partes sólidas e líquidas, chamadas de material particulado (MP), possuem dimensões reduzidas, variando de fração de milímetros a alguns nanômetros. Essas partículas são fundamentais para os processos atmosféricos, como a formação das chuvas, tornando a atmosfera bastante ativa quimicamente.

A figura 2.2.1 mostra como a atmosfera da Terra é estruturada em camadas:

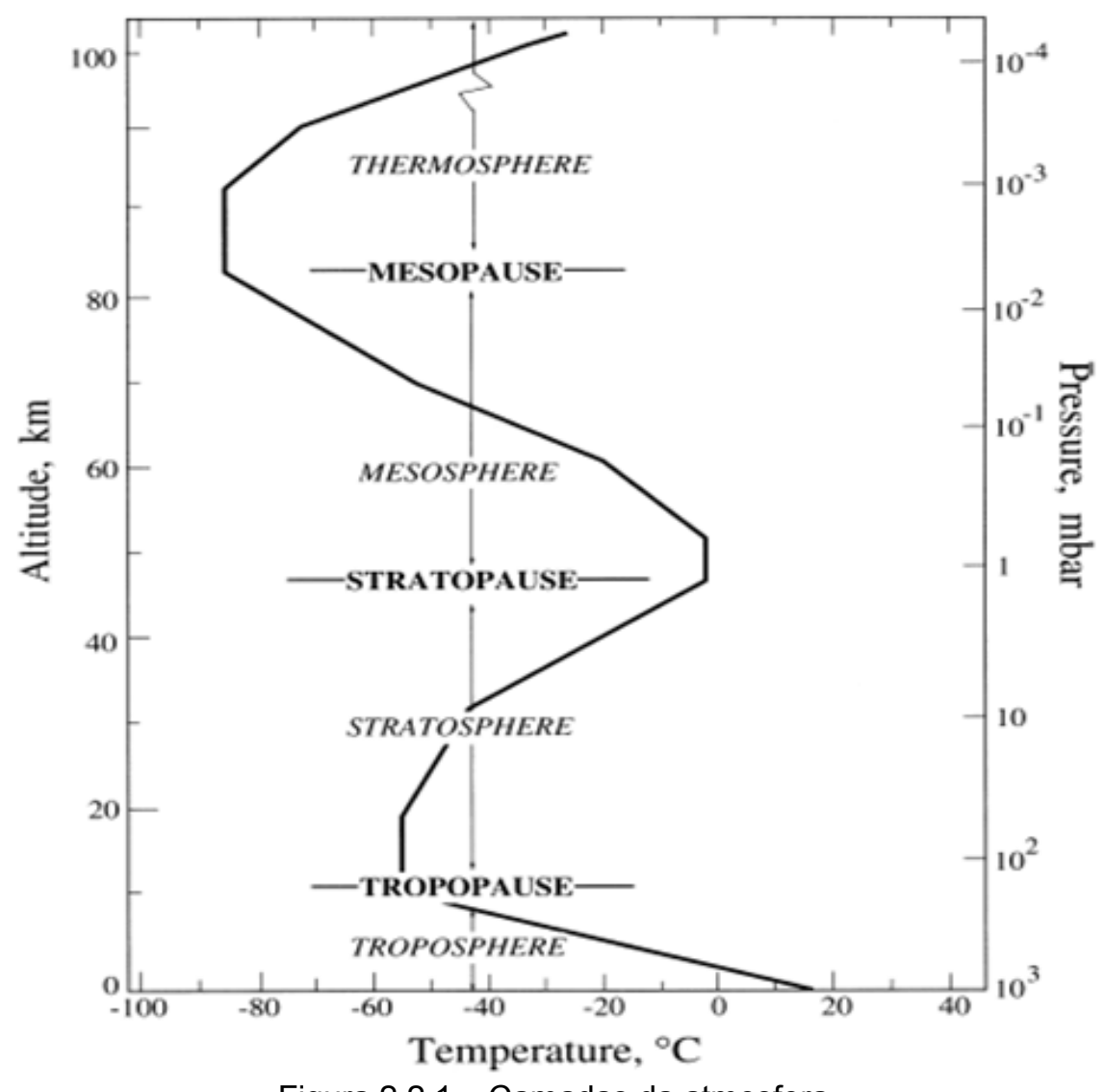

Figura 2.2.1 - Camadas da atmosfera Fonte - Seinfeld e Pandis (2006) 
As camadas da atmosfera mais importantes do ponto de vista da poluição e do clima são a Troposfera e Estratosfera.

A Troposfera (tropo significa movimento) é a camada que vai do solo até cerca de 10 a $15 \mathrm{~km}$ de altitude, dependendo da latitude e da época do ano. Essa camada possui uma característica turbulenta nos períodos de incidência de luz solar. Isso ocorre porque a atmosfera é basicamente transparente à luz solar e quando esta atinge o solo, uma parte da radiação se transforma em calor, aquecendo o solo. $\mathrm{O}$ solo quente acaba aquecendo essa camada mais próxima ao solo por contato. Motivadas pelo empuxo, as massas mais aquecidas em relação às mais frias, normalmente localizadas em maiores altitudes, tendem a subir, fazendo uma mistura dos compostos químicos no sentido vertical. Essa mistura pode ocorrer de maneira rápida e intensa, em questão de minutos ou horas.

A Estratosfera (estrato significa estratificado, por camadas) se inicia logo acima da troposfera e vai de 45 a $55 \mathrm{~km}$ de altitude. Nesta camada, alguns gases, como o Ozônio, mesmo em pequena quantidade, absorvem diretamente uma parte significativa da radiação solar contida na faixa do Ultravioleta (radiação capaz de destruir compostos orgânicos necessários à vida), aquecendo-se de forma crescente com a altitude, tornando-se bastante estável. Não havendo grandes turbulências, a mistura de gases e o transporte vertical de substâncias são lentos, quando comparados com essas ocorrências na Troposfera, podendo demorar meses ou anos. (CAMADA..., 2008).

A camada da atmosfera mais crítica no estudo da poluição do ar é a Camada Limite Planetária (CLP). Esta faixa tem aproximadamente 1.000 metros a partir da superfície do solo, onde a topografia, o perfil de temperatura e a distribuição de pressão têm efeito direto na estrutura e velocidade dos ventos e no nível de turbulência nos gases, determinando o grau de manutenção ou dispersão de um contaminante lançado na atmosfera. Nessa camada, ocorre turbulência tanto de origem mecânica como térmica (convecção). A CLP é dividida em diferentes camadas e apresenta diferentes regimes de turbulência:

- subcamada inercial: onde predomina difusão molecular, com espessura da ordem de 1 milímetro;

- camada limite superficial (CLS): onde predominam as forças inerciais sobre as viscosas, com espessura da ordem de dezenas de metros, onde 
existem gradientes verticais intensos das variáveis atmosféricas: temperatura, umidade e momento;

- camada de mistura (CM): camada que se estende desde o topo da CLS até o topo da CLP (zona de transição), onde os gradientes verticais são muito pequenos devido ao efeito mais intenso da convecção térmica diurna (período de sol e aquecimento da superfície abaixo);

- camada de transição ou zona de estranhamento: camada no topo da CLP, na qual ocorre a transição entre as condições médias das variáveis na CLP e CM e as condições laminares na atmosfera livre, onde não ocorre turbulência fora das regiões instáveis (de cisalhamento do vento) e das térmicas que formam as células de movimento vertical das nuvens. $\mathrm{Na}$ zona de transição ocorre estranhamento, isto é, ar seco e frio (potencialmente quente) penetra na CLP vindo da atmosfera livre, enquanto ar quente e úmido se choca contra a inversão térmica da camada de transição, gerando ondas de gravidade nessa camada estável, em geral associadas à presença de nuvens de bom tempo. Nuvens de bom tempo, em geral, são visíveis na camada de transição durante o período de maior convecção do dia, em geral à tarde, quando a superfície da terra está bastante aquecida e a CLP encontra-se sobre um regime de instabilidade termodinâmica (muito turbulenta devido à convecção térmica).

À noite, a CLP é caracterizada pela Camada Limite Estável (CLE), na qual a intensidade da turbulência é bem menor que a intensidade registrada durante o dia na Camada Limite Convectiva (CLC). A escala de altura da CLE também é inferior à da CLC, sendo da ordem de dezenas de metros. Em geral, a altura do topo da CLE está associada à intensidade do cisalhamento do vento na vertical durante a noite ao grau da inversão térmica de superfície. Durante a noite, a superfície se resfria devido à perda de calor por irradiação infravermelha (radiação de onda longa), e isso leva à formação da inversão de superfície nas noites de céu claro e de baixa umidade do ar. Sobre os oceanos, florestas e cidades o comportamento da CLP difere do descrito acima, que é estritamente válido para CLP sobre superfícies continentais de solo exposto e plano (CAMADA..., 2008)..

O monóxido de carbono (CO), principal poluente abordado neste trabalho, tem tempo de residência na Troposfera de 30 a 90 dias. Sua remoção ocorre principalmente por reação com a Hidroxila $(\mathrm{OH})$, gerando dióxido de carbono $\left(\mathrm{CO}_{2}\right)$ e hidrogênio $(\mathrm{H})$. Uma pequena parte se transfere para o solo e para 
Estratosfera. Nota-se que o resultado final da reação (em torno de 14 semanas) é a produção de $\mathrm{CO}_{2} . \mathrm{O} \mathrm{CO}_{2}$ tem tempo de permanência muito maior na atmosfera, em média centenas de anos. Nesse período, ele altera o reflexo de infravermelho pelo planeta, e, portanto, acaba alterando a temperatura. Há gases poluentes, como o metano $\left(\mathrm{CH}_{4}\right)$, que têm tempo de vida de dezenas de anos. Outros, como o $\mathrm{NO}_{x}$, $\mathrm{SO}_{2}$ e $\circ \mathrm{O}_{3}$, têm tempo de vida de alguns dias ou horas, com alcance regional, de dezenas de quilômetros. Já os radicais $\mathrm{OH}$ e o $\mathrm{NO}_{3}$ têm tempo de vida de segundos a minutos e pequeno raio de ação.

Assim, cada tipo de gás tem um tipo de influência distinta nos receptores, conforme o tempo de dispersão na atmosfera. O CO é mais tóxico para a saúde que $\mathrm{o} \mathrm{CO}_{2} \mathrm{e}$, aquele só vai começar a ser convertido em $\mathrm{CO}_{2}$ aproximadamente em 14 dias. Isso significa que o ser humano estará em contato mais intenso com o $\mathrm{CO}$ durante as primeiras duas semanas após sua emissão, o que se pode prolongar por até 90 dias. Esse contato é menor com os outros gases poluentes prejudiciais, que se dispersam mais rapidamente na atmosfera e chegam a ter pouca influência em receptores há pouca distância do local onde foram emitidos, como acontece com o $\mathrm{NO}_{3}$.

A figura 2.2.2 apresenta os gases nocivos, sua localização na atmosfera e o tempo de dispersão.

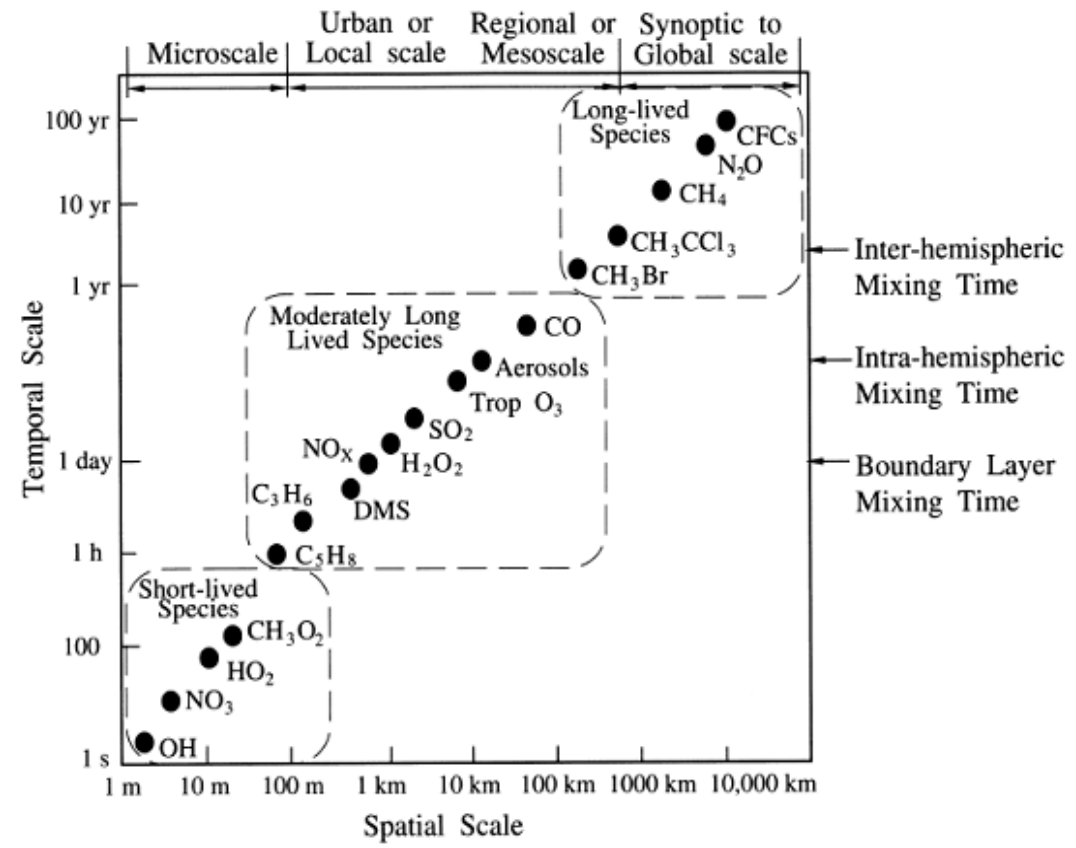

Figura 2.2.2 - Escala temporal e espacial de alguns constituintes da atmosfera Fonte - Seinfeld e Pandis (2006) 
Segundo a Companhia de Tecnologia de Saneamento Ambiental - Cetesb (2008), de acordo com a sua origem, os poluentes podem ser classificados em:

- Poluentes primários: aqueles emitidos diretamente pelas fontes de emissão, como o CO;

- Poluentes secundários: aqueles formados na atmosfera através da reação química entre poluentes primários e/ou constituintes naturais na atmosfera, como o $\mathrm{CO}$ transformado em $\mathrm{CO}_{2}$ após 14 dias.

Os gases são introduzidos ou produzidos na atmosfera por diversas fontes, como as naturais, por meio de atividades biológicas, declínios radioativos, incêndios, e as humanas, por meio de atividades industriais. Os problemas ambientais surgem quando a natureza não consegue reciclar em tempo hábil esses gases, alterando a condição de equilíbrio da atmosfera. A remoção desses gases na troposfera ocorre por processos biológicos, transferência para Estratosfera ou agregação e decantação de partículas, reações químicas diversas, absorções e processos físicos como dissolução em água, chuvas e ventos. A tabela 2.2.1 ilustra as escalas de grandezas.

Tabela 2.2.1 - Escala espacial do fenômeno da química da atmosfera

Table 1.1 Spatial Scales of Atmospheric Chemical Phenomena

\begin{tabular}{ll}
\hline Phenomenon & Length scale, Km \\
\hline Urban air pollution & $1-100$ \\
Regional air pollution & $10-1000$ \\
Acid rain/deposition & $100-2000$ \\
Toxic air pollutants & $0.1-100$ \\
Stratospheric ozone depletion & $1000-40,000$ \\
Greenhouse gas increases & $1000-40,000$ \\
Aerosol - climate interactions & $100-40,000$ \\
Tropospheric transport and oxidation processes & $1-40,000$ \\
Stratospheric-tropospheric exchange & $0.1-100$ \\
Stratospheric transport and oxidation processes & $1-40,000$ \\
\hline
\end{tabular}


Fontes indiretas, como a oxidação $\mathrm{CH}_{4}$ através do radical $\mathrm{OH}$, representam uma parcela significativa na produção de $\mathrm{CO}$, porém as emissões diretas, como a queima da biomassa, as combustões e os processos tecnológicos e industriais, representam a maior parcela dessas emissões. Segundo Seinfeld e Pandis (2006), 2/3 das emissões de CO se originam em atividades humanas.

Nesse contexto, os veículos automotores representam a principal fonte de emissão de $\mathrm{CO}, \mathrm{HCs}$ e $\mathrm{NO}_{2}$ no ar das áreas urbanas, chegando a 90\% do total, segundo estimativa da Environmental Protection Agency - EPA, dos EUA. A frota de veículos vem aumentando ano a ano, contando hoje com quase 750 milhões de veículos terrestres em atividade e os impactos estão cada vez mais presentes.

Essas formas de poluição quase sempre estão relacionadas entre si, como vários trabalhos têm demonstrado (MENDONÇA, 1994). Atualmente, reconhece-se que existe uma grande correlação entre o nível de $\mathrm{CO}$ e $\mathrm{CO}_{2}$ na atmosfera, emitidos pelos veículos automotores e o aumento da temperatura nos locais com grande densidade de tráfego. Um aspecto que deve ser levado em conta nestes locais é o regime de deslocamento dos veículos. Nos instantes iniciais, após o momento de o veículo sair do repouso ou mesmo em outras condições de maior solicitação do motor do veiculo, a emissão desses gases pode sofrer grande alteração.

A intensa interferência do homem com a natureza, particularmente nas regiões mais densamente urbanizadas, faz que ocorram grandes mudanças no microclima dessas regiões. Surgem áreas de intensa poluição, das mais diversas naturezas, como por exemplo, ilhas de calor, ilhas de poluição química ou biológica, poluição sonora e outras.

Alguns trabalhos mostram que levantamentos de dados meteorológicos em vários locais de uma região, utilizando-se equipamentos adequados para registro da temperatura e umidade relativa do ar, além de observações sensíveis para outros elementos como direção e intensidade do vento, nebulosidade, visibilidade e tráfego, podem sem usados para verificar se existe a formação de ilhas de calor. 
Segundo Freitas (2003, p.2-6),

Quando o homem libera compostos químicos na atmosfera, quer sejam eles idênticos àqueles já produzidos pela natureza, quer sejam compostos exóticos, como, por exemplo, algumas substâncias radiativas e os CFCs (clorofluorcarbonados), o equilíbrio físico/químico da atmosfera pode ser alterado e propriedades indesejáveis manifestam-se tais como aquecimento excessivo, efeitos corrosivos, chuvas ácidas, efeitos diretos sobre a saúde de animais, plantas e outros. Este desequilíbrio essencialmente é que chamamos de poluição.

Os gases emitidos pelos veículos são despejados diretamente na atmosfera, que acaba funcionando como um "lixão" de resíduos gasosos. Os gases emitidos pelos veículos têm dupla ação negativa aos seres humanos: uma ação direta quando são emitidos próximos às pessoas e uma ação indireta quando, na atmosfera, se transformam em $\mathrm{CO}_{2}$. Este trabalho, ao estudar a emissão dos gases poluentes de forma mais direta e, portanto, mais realista, pode ajudar a fundamentar a verdadeira influência desses gases na saúde das pessoas.

\subsection{Emissões de gases por veículos automotores}

Veículos emitem uma grande quantidade de poluentes, talvez, em uma estimativa grosseira, quase a metade da poluição que se encontra no ar. Segundo Alvim et al. (2008) foram obtidos os seguintes dados:

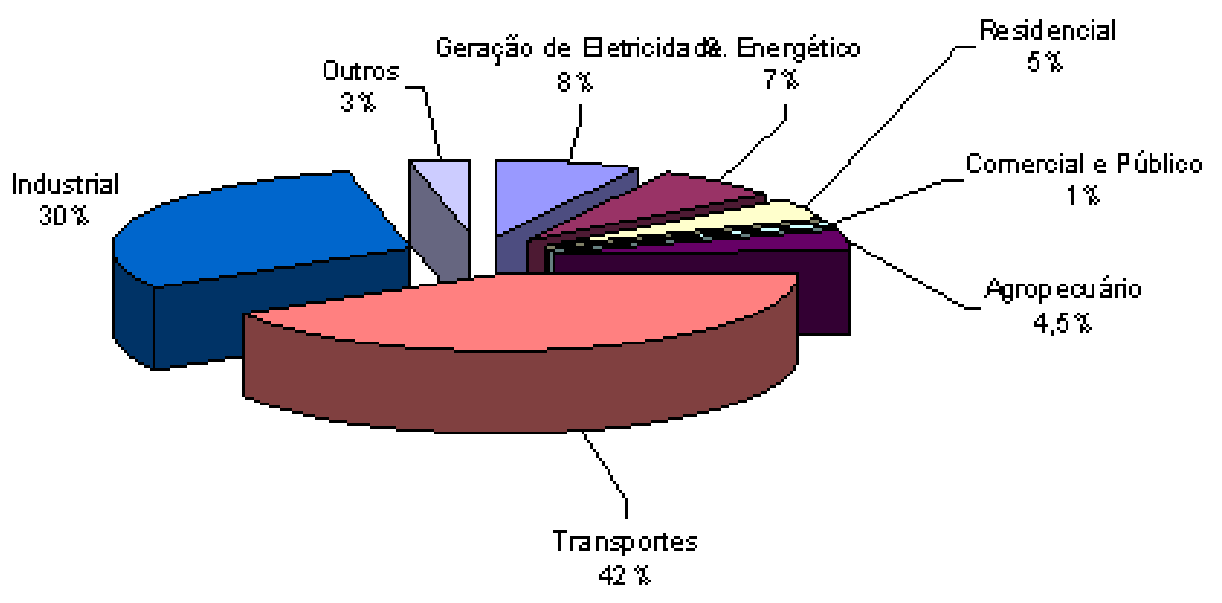

Figura 2.3.1 - Emissões de carbono por setor em 2006 Fonte - Alvim et al. (2008) 
A figura 2.3.1 mostra a participação das emissões de carbono no uso da energia por setor com destaque para o setor transportes, responsável por $42 \%$ do total.

Alguns dos principais produtos da combustão em veículos automotores são o dióxido de carbono $\left(\mathrm{CO}_{2}\right)$, água $\left(\mathrm{H}_{2} \mathrm{O}\right)$, monóxido de carbono (CO), hidrocarbonetos não ou parcialmente oxidados (HCs), aldeídos (R-CHO), óxidos de nitrogênio $\left(\mathrm{NO}_{\mathrm{x}}\right)$, óxidos de enxofre $\left(\mathrm{SO}_{\mathrm{x}}\right)$ e material particulado $(\mathrm{MP})$. $\mathrm{O}$ ozônio troposférico $\left(\mathrm{O}_{3}\right)$, outro importante poluente, tem a sua formação associada à presença de $\mathrm{HC}_{\text {e }} \mathrm{NO}_{x}$ (MENDES, 2004).

O tipo e a composição do combustível usado nos automóveis influenciam, de modo significativo, nas diferentes formas de contaminação às quais o meio ambiente está sujeito. Os automóveis movidos a álcool, por exemplo, produzem altas emissões de aldeídos (principalmente formaldeído e acetaldeído) em relação àqueles movidos à gasolina. Os veículos movidos por misturas $20 \%$ etanolgasolina ( $\mathrm{v} / \mathrm{v})$ emitem mais aldeídos totais e óxidos de nitrogênio do que a gasolina. São também elevadas as emissões de álcool não-carburado, principalmente com a ignição a frio. As emissões originadas pelo uso de veículos automotores, segundo Mendes (2004), podem ser divididas nas seguintes categorias:

- Emissões de gases e partículas pelo escapamento do veículo (subprodutos da combustão lançados à atmosfera pelo tubo de escapamento);

- Emissões evaporativas de combustível (lançadas na atmosfera através de evaporação de hidrocarbonetos do combustível);

- Emissões de gases do cárter do motor (subprodutos da combustão que passam pelos anéis de segmento do motor e por vapores do óleo lubrificante);

- Emissões de partículas provenientes do desgaste de pneus, freios e embreagem;

- Re-suspensão de partículas de poeira do solo;

- Emissões evaporativas de combustível nas operações de transferência de combustível (associadas ao armazenamento e abastecimento de combustível). 
As emissões de gases poluentes também variam de acordo com a maneira com que o veículo é conduzido (acelerações fortes, momento de mudança de marcha, marcha lenta, velocidades médias, pouca ou muita carga, etc.), a tecnologia empregada (principalmente no sistema de alimentação e combustão), o tipo de combustível empregado, presença de dispositivos de controle de emissão como os conversores catalíticos.

Situações das vias de tráfego como valetas, obstáculos, localizações de semáforos, paradas de ônibus, geometria das vias, qualidade da pista de rolamento também interferem muito nos padrões de emissão de poluentes.

A figura 2.3.2 a mostra a origem de vários poluentes de acordo com sua fonte poluidora. Os veículos leves se mostram os maiores responsáveis pela emissão de $\mathrm{CO}$ e $\mathrm{HC}$.

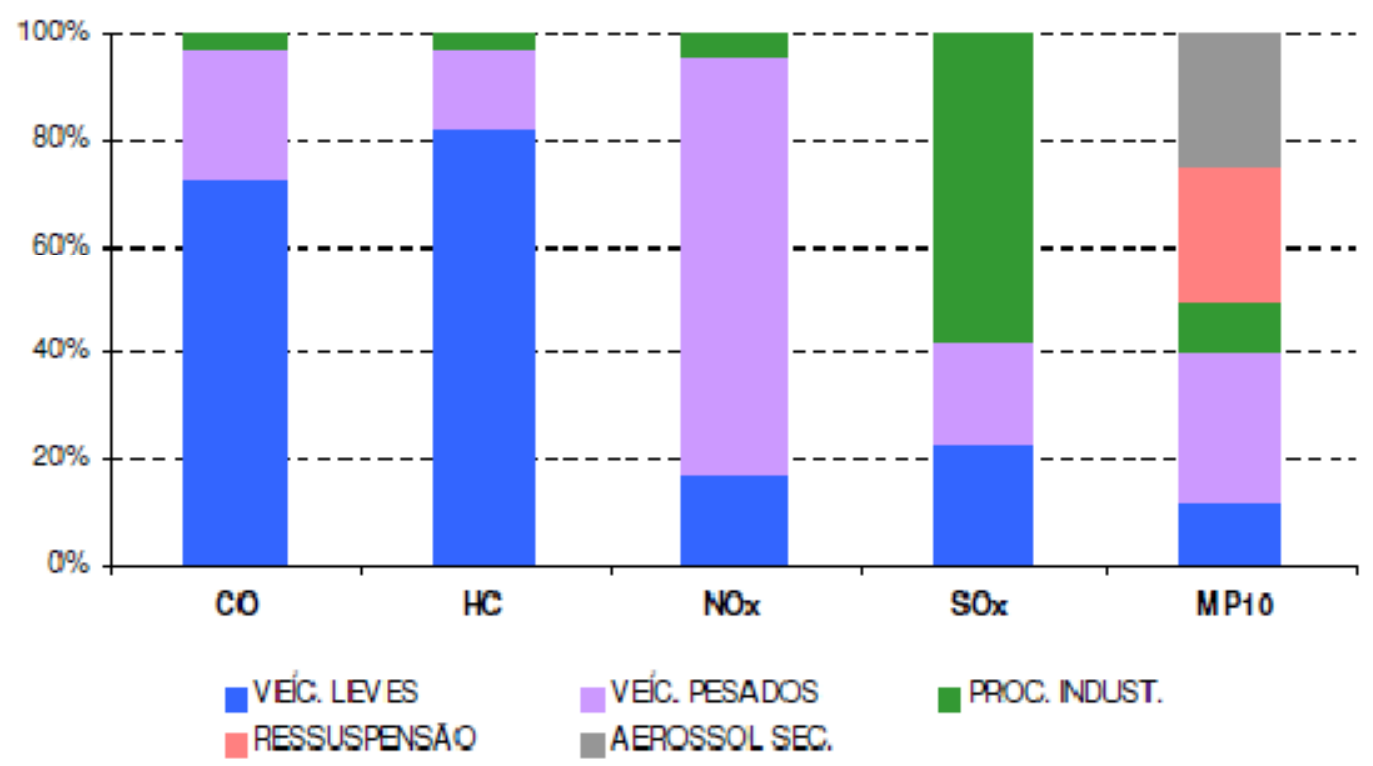

Figura 2.3.2 - Emissões relativas de poluentes por tipo de fontes - 2005

Fonte - Cetesb (2008)

A tabela 2.3.1 apresenta dados relativos à emissão de poluentes e suas fontes. 
Tabela 2.3.1 - Contribuição relativa das fontes de poluição do ar na RMSP em 2005

\begin{tabular}{|c|c|c|c|c|c|c|c|}
\hline \multirow{2}{*}{\multicolumn{3}{|c|}{ Fontes de emissão }} & \multicolumn{5}{|c|}{ Emissão (1000T/ANO) } \\
\hline & & & \multirow{2}{*}{$\begin{array}{c}\mathrm{CO} \\
667,1\end{array}$} & \multirow{2}{*}{$\begin{array}{c}\mathrm{HC} \\
83,2\end{array}$} & \multirow{2}{*}{$\begin{array}{l}\mathrm{NO}_{\mathrm{x}} \\
41,0\end{array}$} & \multirow{2}{*}{$\begin{array}{c}\mathrm{SO}_{x} \\
6,2\end{array}$} & \multirow{2}{*}{$\begin{array}{l}\text { MP } \\
5,0\end{array}$} \\
\hline \multirow{11}{*}{ Móveis } & \multirow{5}{*}{$\begin{array}{l}\text { Tubo de } \\
\text { escapamento de } \\
\text { veículos }\end{array}$} & Gasolina c & & & & & \\
\hline & & Álcool+flex & 186,4 & 20,1 & 11,0 & -- & -- \\
\hline & & Diesel & 363,7 & 57,3 & 260,6 & 5,6 & 13,9 \\
\hline & & Táxi & 1,8 & 1,0 & 2,1 & -- & -- \\
\hline & & $\begin{array}{l}\text { Motocicleta e } \\
\text { similares }\end{array}$ & 245,4 & 32,6 & 1,8 & 0,4 & 0,8 \\
\hline & \multirow{3}{*}{ Carter e evaporativa } & Gasolina c & -- & 124,6 & -- & -- & -- \\
\hline & & Álcool & -- & 14,2 & -- & -- & -- \\
\hline & & $\begin{array}{l}\text { Motocicleta e } \\
\text { similares }\end{array}$ & -- & 20,9 & -- & -- & -- \\
\hline & Pneus & Todos os tipos & -- & -- & -- & -- & 8,5 \\
\hline & \multirow{2}{*}{$\begin{array}{l}\text { Operação de } \\
\text { transferência de } \\
\text { combustível }\end{array}$} & Gasolina C & -- & 13,5 & -- & -- & -- \\
\hline & & Álcool & -- & 1,0 & -- & -- & -- \\
\hline \multirow[t]{2}{*}{ Fixas } & \multicolumn{2}{|c|}{$\begin{array}{l}\text { Operação de processos industriais ( } \mathrm{n}^{\circ} \\
\text { de indústrias inventariadas) }\end{array}$} & $\begin{array}{l}38,6 \\
(750)\end{array}$ & $\begin{array}{l}12,05 \\
(800)\end{array}$ & $\begin{array}{l}14,0 \\
(740)\end{array}$ & $\begin{array}{c}17,1 \\
(245)\end{array}$ & $\begin{array}{l}31,6 \\
(308)\end{array}$ \\
\hline & \multicolumn{2}{|c|}{ Total } & 1503,0 & 380,4 & 330,5 & 29,3 & 59,7 \\
\hline
\end{tabular}

A tabela 2.3.2 mostra o fator de emissão médio adotado pela Cetesb e suas fontes geradoras.

Tabela 2.3.2 - Fatores médios de emissão dos veículos em uso na RMSP em 2005

\begin{tabular}{|c|c|c|c|c|c|c|}
\hline \multirow{2}{*}{ Fonte de emissão } & \multirow{2}{*}{ Tipo de veículo } & \multicolumn{5}{|c|}{ Fator de emissão $(\mathrm{g} / \mathrm{km})$} \\
\hline & & $\mathrm{CO}$ & $\mathrm{HC}$ & $\mathrm{NO}_{\mathrm{x}}$ & $\mathrm{SO}_{\mathrm{x}}$ & MP \\
\hline \multirow{6}{*}{ Tubo de escapamento } & Gasolina C & 10,70 & 1,11 & 0,66 & 0,10 & 0,08 \\
\hline & Álcool & 19,70 & 2,12 & 1,16 & -- & -- \\
\hline & Flex (álcool) & 0,44 & 0,15 & 0,11 & -- & -- \\
\hline & Diesel & 15,00 & 2,36 & 10,74 & 0,21 & 0,57 \\
\hline & Táxi & 0,80 & 0,44 & 0,90 & -- & -- \\
\hline & $\begin{array}{l}\text { Motocicleta e } \\
\text { similares }\end{array}$ & 16,40 & 2,18 & 0,12 & 0,03 & 0,05 \\
\hline \multirow{3}{*}{$\begin{array}{l}\text { Emissão do carter e } \\
\text { evaporativa }\end{array}$} & Gasolina C & -- & 2,00 & -- & -- & -- \\
\hline & Álcool & -- & 1,50 & -- & -- & -- \\
\hline & $\begin{array}{l}\text { Motocicleta e } \\
\text { similares }\end{array}$ & -- & 1,40 & -- & -- & -- \\
\hline Pneus & Todos os tipos & -- & -- & -- & -- & 0,07 \\
\hline
\end{tabular}


$\mathrm{Na}$ combustão incompleta, ocorre uma queima imperfeita com geração de poluentes (DETRAN-RJ; FEEMA, 2001). A equação 2.3.2 ilustra o processo de combustão incompleta, gerando poluentes.

\section{Equação 2.3.2 - Processo de combustão incompleta}

$$
\mathrm{C}_{n} \mathrm{H}_{m}+\mathrm{O}_{2}+\mathrm{N}_{2} \rightarrow \mathrm{CO}_{2}+\mathrm{H}_{2} \mathrm{O}+\mathrm{N}_{2}+\underbrace{\mathrm{CO}+\underbrace{}_{\text {Incompleta }}+{ }_{n} \mathrm{H}_{m}+\mathrm{NO}}_{\text {Combustão }}+{ }_{x}+\mathrm{C}
$$

Os principais poluentes lançados na atmosfera pelos veículos automotores são provenientes do processo de combustão incompleta, sendo geralmente quantificadas as emissões de $\mathrm{CO}$, hidrocarbonetos $\left(\mathrm{HC}\right.$ ou $\left.\mathrm{C}_{n} \mathrm{H}_{\mathrm{m}}\right)$, óxidos de enxofre $\left(\mathrm{SO}_{\mathrm{x}}\right)$, óxidos de nitrogênio $\left(\mathrm{NO}_{\mathrm{x}}\right)$ e material particulado (MP) (FEEMA, 2004).

Cada um desses poluentes é emitido em maior ou menor quantidade em função do combustível utilizado, do tipo de motor, da sua regulagem, da manutenção e do modo de dirigir. Os veículos podem poluir mesmo sem estar em funcionamento, pois com o motor desligado ocorre evaporação de combustível pelo suspiro do tanque e no sistema de carburação do motor, sendo grande parte desses vapores lançada na atmosfera. Nos veículos novos, essas emissões foram bastante controladas com a adição de certas tecnologias (catalisadores, injeção eletrônica de combustível etc). Apesar de, individualmente, esse tipo de emissão ser aparentemente insignificante, ao se analisar o número de veículos existentes nas grandes cidades, verifica-se a geração de toneladas de poluentes por dia (FAIZ et al., 1996).

Assim, a emissão de CO é produto da oxidação parcial do carbono em função da qualidade da mistura, da temperatura do motor e da quantidade de $\mathrm{O}_{2}$ disponível no momento da queima.

Cada um dos tipos de combustível utilizados comumente nos veículos automotores brasileiros será estudado detalhadamente a seguir. 


\subsubsection{Gasolina}

A gasolina é um derivado de petróleo formado por uma mistura complexa de hidrocarbonetos e alguns contaminantes como o enxofre, o nitrogênio e certos metais, que é utilizada em máquinas de combustão interna por centelha. A composição e as características da gasolina dependem basicamente da natureza do petróleo (de origem), dos processos de refino pelos quais passou e das especificações de qualidade.

As quatro principais famílias de compostos orgânicos que constituem a gasolina são as olefinas, os aromáticos, os alcanos e os cicloalcanos (DE SOUZA, 2004; FARAH, 2004; MACLEAN, LAVE, 2003).

No Brasil, a gasolina não é o derivado de maior produção, mas ainda é o combustível mais importante no mercado consumidor, sendo o mais representativo.

Segundo Silva e Ferraz (1994), Maclean e Lave. (2003) e Sher (1998), as principais características que definem a qualidade de uma gasolina automotiva são a volatilidade e a capacidade antidetonante, medidas, basicamente, pelos ensaios de destilação, pressão de vapor e os parâmetros de octanagem. A seguir as principais características que são avaliadas na gasolina e a sua correlação com as emissões:

- Destilação - os pontos de destilação usualmente controlados na produção da gasolina são $10 \%, 50 \%$ e $90 \%$ evaporados e o ponto final de destilação. O ponto $10 \%$ influencia, principalmente, na facilidade da partida do motor e deve ser equilibrado com a ocorrência de tamponamento por vapor ocasionado pela presença de hidrocarbonetos leves (alta pressão de vapor). O ponto $50 \%$ influencia no tempo necessário para que o motor atinja as condições normais de aceleração. O ponto $90 \%$ e o final de destilação influenciam na formação de depósitos na câmara de combustão e nas velas, devido à combustão incompleta.

- Pressão de Vapor Reid - a pressão de vapor da gasolina influencia na tendência ao tamponamento por vapor, que se caracteriza pela interrupção do fluxo de combustível líquido para o injetor, em face da vaporização de grande quantidade da gasolina. Uma pressão de vapor alta contribui para elevação das emissões evaporativas, através de respiros e vazamentos, nos postos de serviço durante o abastecimento de veículos e nos tanques de armazenamento. As emissões 
evaporativas se caracterizam pela liberação de hidrocarbonetos que, em presença de $\mathrm{NO}_{x}$ e luz solar, participam da formação de ozônio.

- Capacidade antidetonante - é uma medida da resistência à tendência detonação. É função do projeto e da operação do motor, além das condições atmosféricas. A composição da gasolina influencia diretamente a sua resistência à detonação.

O controle das emissões de escapamento dos veículos movidos à gasolina é uma tarefa complexa e que está relacionada a uma série de itens como:

1 - características da formulação da gasolina;

2 - razão ar combustível (é usualmente menor do que a estequiométrica);

3 - tempos de ignição e razões de compressão;

4 - velocidade, condições, depósitos e carga do motor;

5 - temperatura do radiador;

6 - configuração da câmara de combustão.

A combustão ideal de uma mistura estequiométrica que usa isooctano como representativo do combustível gera as seguintes emissões: (SANTOS, 2008, Informação pessoal) $)^{2}$

Equação 2.3.1.1 - Mistura estequiométrica queima completa

$$
\underbrace{\mathrm{C}_{8} \mathrm{H}_{18}}_{\text {Combustivel }}+\underbrace{15,5 \mathrm{O}_{2}}_{\mathrm{Ar}}+\underbrace{12,5 \cdot 3,76 \mathrm{~N}_{2}}_{\text {Emissões da combustão completa }} \rightarrow \underbrace{8 \mathrm{CO}_{2}+\frac{\mathrm{H}_{2} \mathrm{O}}{\mathrm{O}}+\frac{47 \mathrm{~N}_{2}}{2}}
$$

Massa de combustível $\left(\mathrm{C}_{8} \mathrm{H}_{18}\right): 8^{*}(12)+18^{*}(1)=114 \mathrm{~kg}$ de combustível Massa de $\operatorname{ar}\left(12,5^{*} 0_{2}+12,5^{\star} 3,76^{\star} \mathrm{N}_{2}\right): 12,5^{\star}\left(2^{\star} 16\right)+12,5^{\star} 3,76^{\star}\left(2^{\star} 14\right)=1716 \mathrm{~kg}$ de ar Massa de $\mathrm{CO}_{2}$ produzida: $8^{*}\left(\mathrm{C}+2^{*} \mathrm{O}\right)=8^{*}\left(12+2^{*} 16\right)=352 \mathrm{~kg}$ Massa de $\mathrm{H}_{2} \mathrm{O}$ produzida: $9^{*}\left(2^{*} \mathrm{H}+\mathrm{O}\right)=9^{*}\left(2^{*} 1+16\right)=162 \mathrm{~kg}$ Massa de $\mathrm{N}_{2}$ produzida: $47^{*}\left(2^{*} \mathrm{~N}\right)=47^{*}\left(2^{*} 14\right)=1316 \mathrm{~kg}$ Massa de gases produzida: $352 \mathrm{~kg}(\mathrm{CO})+162 \mathrm{~kg}\left(\mathrm{H}_{2} \mathrm{O}\right)+1316 \mathrm{~kg}\left(\mathrm{~N}_{2}\right)=1830 \mathrm{~kg}$ gases

\footnotetext{
${ }^{2}$ Informação pessoal fornecida pelo Prof.Dr.Antonio Moreira dos Santos, em 2008.
} 
A relação volumétrica é igual à relação molar, assim:

1 Mol de combustível $+12,5$ Mols de $\mathrm{O}_{2}+47$ Mols de $\mathrm{N}_{2}$ produzem em queima completa 8 Mols de $\mathrm{CO}_{2}+9$ Mols de $\mathrm{H}_{2} \mathrm{O}+47$ Mols de $\mathrm{N}_{2}$. Assim 60,5 Mols de mistura ar combustíveis consumidos, geram-se 64 Mols de gases na queima completa.

A relação ar combustível fica para essa situação:

Equação 2.3.1.2 - Relação ar combustível $A C_{e}=\frac{1716}{114}=15,05 \mathrm{Kg}$ ar $/ \mathrm{Kg}_{\text {comb }}$

Assim $1 \mathrm{~kg}$ de $\mathrm{C}_{8} \mathrm{H}_{18}$ consome $15,05 \mathrm{~kg}$ de ar na combustão.

Quando a razão ar combustível real é inferior à razão ar combustível estequiométrica, a mistura é considerada rica. Quando a razão ar combustível real é superior à razão ar combustível estequiométrica a mistura é considerada pobre.

Equação 2.3.1.3 - Mistura rica e mistura pobre

$$
\lambda=\frac{A C_{\text {real }}}{A C_{e}}<1 \text {, mistura rica e } \lambda=\frac{A C_{\text {real }}}{A C_{e}}>1 \text { mistura pobre }
$$

Tipicamente a emissão de $\mathrm{CO}_{2}$ e $\mathrm{H}_{2} \mathrm{O}$ do combustível representado por $\mathrm{C}_{8} \mathrm{H}_{18}$ em função do consumo de combustível pode ser descrito: Massa de $\mathrm{CO}_{2} / \mathrm{kg}$ de gasolina: $352 / 114=3,09 \mathrm{~kg}$ de $\mathrm{CO}_{2} / \mathrm{kg}$ de gasolina Massa de $\mathrm{CO}_{2}$ / litro de gasolina: 3,09*0,73 = 2,26 kg de $\mathrm{CO}_{2}$ / litro de gasolina Massa de $\mathrm{H}_{2} \mathrm{O} / \mathrm{kg}$ de gasolina: 162 / $114=1,42 \mathrm{~kg}$ de $\mathrm{H}_{2} \mathrm{O} / \mathrm{kg}$ de gasolina Massa de $\mathrm{H}_{2} \mathrm{O} /$ litro de gasolina: $1,42^{*} 0,73=1,04 \mathrm{~kg}$ de $\mathrm{H}_{2} \mathrm{O} /$ litro de gasolina

O poder calorífico do combustível (energia liberada pela combustão de $1 \mathrm{~kg}$ de combustível) depende da sua concentração de carbono e hidrogênio. No hidrogênio, o poder calorífico é $28.700 \mathrm{Kcal} / \mathrm{kg}$, enquanto que no 
carbono é $8.140 \mathrm{Kcal} / \mathrm{kg}$, por isso, quanto mais rico em hidrogênio for o combustível maior será o seu poder calorífico. Há dois tipos de poder calorífico:

- Poder calorífico superior: é a quantidade de energia liberdada por $1 \mathrm{~kg}$ de combustível, quando este entra em combustão, em excesso de ar, e os gases da descarga são resfriados, de modo que o vapor de água neles seja condensado.

- Poder calorífico inferior: é a quantidade de energia liberada por $1 \mathrm{~kg}$ de combustível, quando este entra em combustão com excesso de ar e os gases de descarga são resfriados até o ponto de ebulição da água, evitando assim que a água contida na combustão seja condensada. Como a temperatura dos gases de combustão é muito elevada nos motores endotérmicos, a água contida neles se encontra sempre na fase vapor, portanto, o que deve ser considerado é o poder calorífico inferior e não o superior.

Equação 2.3.1.4 - Fórmula para determinação do poder calorífico aproximado dos combustíveis

$$
P C S=33900^{*} C+141800^{*}\left(H-\left(\frac{O}{8}\right)\right)+9200^{*} S \text { e } P C I=P C S-2440 *(9 * H+U)
$$

PCS=Poder Calorífico Superior $(\mathrm{KJ} / \mathrm{Kg})$

$\mathrm{C}=$ Teor de Carbono

$\mathrm{H}=$ Teor de Hidrogênio

$\mathrm{S}=$ Teor de Enxofre

$\mathrm{O}=$ Teor de Oxigênio

$\mathrm{PCl}=$ Poder Calorífico Inferior $(\mathrm{KJ} / \mathrm{Kg})$

$\mathrm{U}=$ Teor de umidade

\subsection{2 Álcool}

O metanol e o etanol são os dois álcoois geralmente considerados como combustíveis automotivos. O metanol é produzido principalmente a partir do gás natural, do carvão, de óleos residuais e de biomassa (SHER, 1998). O etanol ou álcool etílico pode ser produzido pela fermentação do açúcar extraído a partir de biomassa (como cana-de-açúcar, milho etc) ou pela hidratação catalítica do etileno. Como combustível, o etanol pode ser utilizado na forma hidratada ou na forma anidra em combinação com a gasolina. O metanol e o 
etanol assemelham-se muito no que se refere às propriedades físicas e de combustão, contudo o etanol é menos tóxico e corrosivo, além de possuir uma quantidade de energia por unidade de volume maior (FAIZ et al., 1996).

A adição de etanol anidro na gasolina no Brasil decorre de diversos motivos (políticos, econômicos, sociais e ambientais), dentre os quais, a eliminação do chumbo tetraetila (antidetonante) da gasolina, um composto tóxico que leva à formação de depósitos na câmara de combustão e no pote de catalisador de oxi-redução e emite chumbo inorgânico nos gases de combustão (FARAH, 2004; SZLO et al., 2003).

Quando comparado com a gasolina, o etanol apresenta maior valor de octanagem, maior velocidade para inflamar, mais calor de vaporização e faixa de limites de inflamabilidade mais extensa. Além disso, a maior razão de compressão (12:1) e o menor tempo de queima indicam vantagens teóricas de eficiência do álcool sobre a gasolina nas máquinas de combustão interna (ICE). As desvantagens de utilização do etanol são as menores densidades de energia, características de corrosão bem mais severas, menor pressão de vapor (partida a frio mais difícil), miscibilidade com a água e a toxicidade para os ecossistemas. A utilização do etanol misturado à gasolina (gasool) diminui alguns benefícios inerentes de utilização etanol, como a baixa volatilidade, a presença de benzeno e as emissões de CO (FAIZ et al., 1996).

O álcool praticamente não possui enxofre em sua composição, logo o seu uso não contribui para a emissão de $\mathrm{SO}_{\mathrm{x}}$. A menor complexidade molecular do álcool possibilita uma combustão com baixíssima formação de partículas de carbono o que resulta em uma emissão desprezível de MP (DUBEUX, [2006?]).

A utilização do álcool reduz as emissões de hidrocarbonetos e a formação de $\mathrm{NO}_{x}$, já que a temperatura de chama é menor. A principal desvantagem em termos de emissões na utilização do etanol como combustível se refere às emissões de aldeídos (acetaldeído e formaldeído), que são formados a partir de reações com parte do combustível não queimado. Contudo, essas emissões podem ser controladas pela utilização de conversores catalíticos (FAIZ et al., 1996, ONURSAL; GAUTAN, 1997; SHER, 1998).

As tecnologias de controle das emissões por exaustão para o álcool hidratado e para o gasool em veículos leves têm melhorado muito ao longo 
dos anos. As tecnologias correntes incluem injeção de combustível multiponto (MPFI), ignição eletrônica mapeada e o conversor catalítico de três vias com controle feedback da razão ar-combustível (ONURSAL; GAUTAN, 1997).

As perspectivas de crescimento do álcool são muitas, pois com a entrada no mercado dos carros bi-combustíveis ou "flex-fuel" (podem utilizar gasolina, álcool ou uma mistura em diversas proporções dos dois combustíveis) esse combustível volta a ter significativa importância no mercado. O estímulo à produção de veículos com combustível flexível começou em agosto de 2002, quando o governo brasileiro decidiu estender para esse tipo de motorização o beneficio tributário existente para a produção de veículos a álcool. A redução de dois pontos percentuais na taxação do IPI passou a valer tanto para o carro a álcool como para o veiculo a combustível flexível. Outro fator de estímulo no mercado de álcool é a possibilidade de adição de etanol ao diesel. Testes mostraram que a utilização de mistura de $3 \%$ de etanol para $97 \%$ de diesel pode ser adotada em qualquer motor sem ocasionar problemas e reduzindo, comprovadamente, as emissões de material particulado e de outros poluentes (GELLER et al., 2004; HESKETH, 1972).

Os veículos a álcool emitem cerca de um terço do $\mathrm{CO}$ emitido pelos veículos movidos pela mistura de gasolina com $20 \%$ de álcool (gasool). Assim, é possível ocorrer uma oxigenação natural do combustível, já que o gasool tem em sua estrutura molecular o radical $\mathrm{OH}$, principal agente da oxidação do $\mathrm{CO}$ para o $\mathrm{CO}_{2}$.

A tecnologia tem grande impacto na emissão de poluentes principalmente quando comparadas às emissões de $\mathrm{CO}$ de um veículo com sistema de alimentação carburada com um veículo equipado com injeção eletrônica de combustível.

A emissão evaporativa em um veículo estacionado ao sol por tempo prolongado pode produzir, através da evaporação de combustível, quase as mesmas emissões de HCs que produziria se estivesse em movimento. A produção de HCs no motor é originada pela queima incompleta do combustível, o que produz um fracionamento da molécula original e a emissão de radicais químicos que ao sair da câmara de combustão e atingir as partes mais frias do sistema de exaustão se mantém inalterados até saírem pelo escape. A preparação da mistura e o desenho da câmara de combustão são decisivos para emissão desse poluente. Os veículos mais modernos já são equipados com reservatórios que evitam parcialmente essa 
evaporação, através de circuitos que interligam o cárter e tanque ao sistema de admissão com válvulas controladoras e tanque de carvão ativado. (GELLER et al., 2004).

O $\mathrm{CO}$ e os $\mathrm{HCs}$ são produtos diretos de reações químicas, enquanto que o $\mathrm{NO}_{\mathrm{x}}$ surge da decomposição e posterior rearranjo das moléculas de $\mathrm{N}_{2}$ e $\mathrm{O}_{2}$ presentes no próprio ar da combustão. Esse fenômeno se agrava pelo efeito das altas temperaturas, que chegam a picos de $2000^{\circ} \mathrm{C}$.

\subsection{Geração, dispersão e consequências de poluentes em escala urbana}

O clima tem grande influência na dispersão dos poluentes gasosos ou particulados presentes no ar, mas outros fatores como a geometria, a altura e o adensamento das edificações também têm um papel a desempenhar. Entre os fatores climáticos diretamente relacionados com a dispersão, os mais significativos são o perfil vertical de temperatura e a velocidade e direção dos ventos. Fatores importantes a observar como a altura das edificações, seu adensamento, alinhamento e a presença ou não de espaços abertos, que são fundamentais pelo peso que têm na ação dos ventos, e consequentemente na dispersão dos poluentes, nem sempre são levados em conta. As condições de tráfego na via pública, incluindo velocidade média, acelerações e fluxo de veículos, afetam, por sua vez, tanto a produção como a dispersão dos poluentes. Nota-se também que outras variáveis, como a tecnologia empregada na fabricação dos motores e o estado de conservação dos veículos são importantes nesta equação. No final, todas essas variáveis é que irão determinar a qualidade do ar nos ambientes urbanos. Devem, portanto, ser consideradas em seu conjunto ao se abordar esse tipo de poluição.

Além dessas variáveis, deve-se levar em conta o efeito estufa, que é um fenômeno causado pelo acúmulo de gases e nuvens na atmosfera, que provoca o aquecimento da superfície do planeta, pelo bloqueio de parte da radiação infravermelha emitida pela superfície terrestre. Os gases que provocam o efeito estufa se situam a uma distância de 10 a $16 \mathrm{~km}$ da superfície do planeta, na parte da 
atmosfera conhecida como troposfera (BAIRD, 2002). Alguns gases de efeito estufa ocorrem naturalmente na atmosfera, como o vapor d'água $\left(\mathrm{H}_{2} \mathrm{O}\right)$, o dióxido de carbono $\left(\mathrm{CO}_{2}\right)$, o metano $\left(\mathrm{CH}_{4}\right)$, o óxido nitroso $\left(\mathrm{N}_{2} \mathrm{O}\right)$ e o ozônio $\left(\mathrm{O}_{3}\right)$. Esses gases atuam como uma cobertura natural, mantendo a temperatura da Terra propícia ao desenvolvimento das diferentes formas de vida. Sem esse fenômeno, a temperatura média da Terra seria em torno de $18^{\circ} \mathrm{C}$ negativos. Devido ao efeito estufa, a temperatura média da superfície terrestre é de $15^{\circ} \mathrm{C}$, ou seja, aproximadamente $33^{\circ}$ mais quente (BAIRD, 2002).

Como os gases de efeito estufa provocam um bloqueio maior, a Terra se aquece mais do que o habitual, causando uma série de problemas climáticos. O problema não está na existência dos gases de efeito estufa, mas no aumento de suas concentrações na atmosfera (BAIRD, 2002). A entrada da radiação solar tem que ser equilibrada por uma saída de calor (radiação térmica) emitida pela Terra. Os gases atmosféricos que regulam o sistema climático da Terra interceptam a radiação solar e fazem que $30 \%$ da energia dos raios solares que chegam sejam refletidos de volta para o espaço. O restante $(70 \%)$ é absorvido pela Terra e pela atmosfera, aquecendo a superfície do planeta. A Terra, então aquecida, re-emite energia sob a forma de radiação térmica (radiação infravermelha de onda longa), que tem sua passagem bloqueada principalmente pelo vapor de água e dióxido de carbono existente na atmosfera (BAIRD, 2002). Da radiação térmica emitida pelo globo terrestre, cerca de $90 \%$ são absorvidos pela atmosfera, que irradia em torno de $80 \%$ novamente para a superfície terrestre. É esse processo que mantém a Terra confortavelmente aquecida. Apenas uma pequena quantidade de radiação terrestre escapa para o espaço.

A figura 2.4.1 apresenta um diagrama simplificado do efeito estufa. Observa-se, entretanto que, no equilíbrio, o total de energia solar que entra no sistema é igual ao total de energia térmica que sai (balanço de energia: SAÍDAS = ENTRADAS). $\mathrm{O}$ equilíbrio é rompido pela intensificação do fenômeno que ocorre em função das atividades humanas, uma vez que, ao aumentar a quantidade de gases estufa na atmosfera, maior é a retenção de calor (RIBEIRO et al., 2003). 


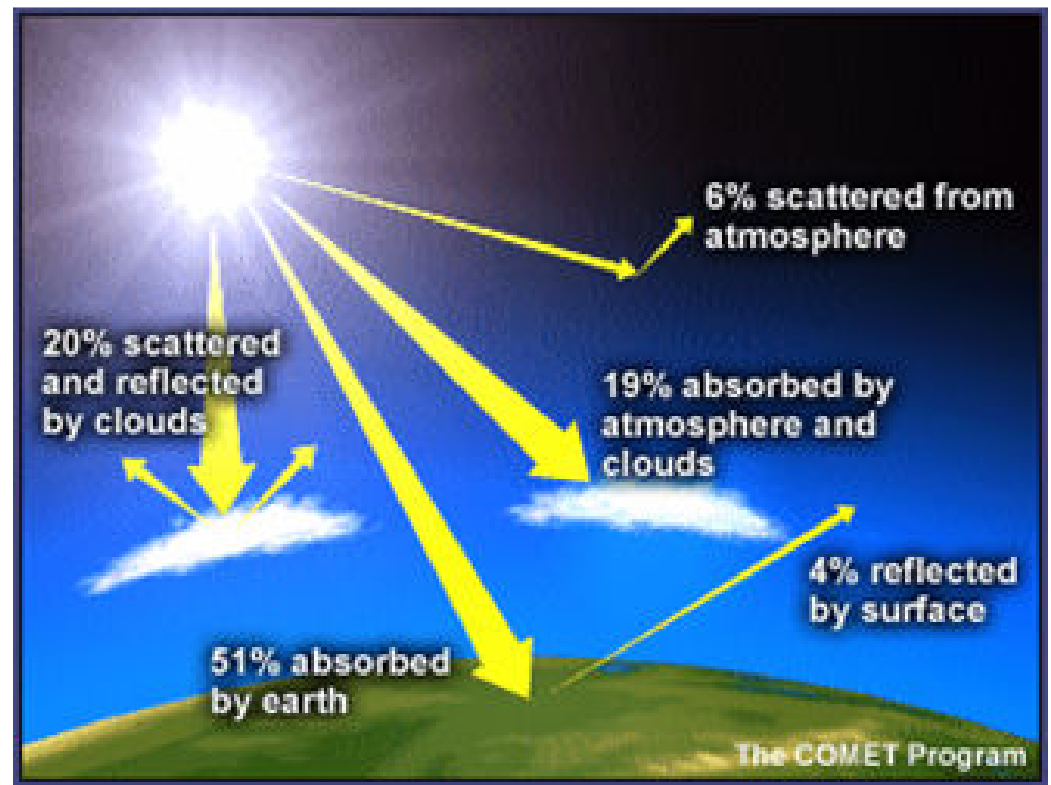

Figura 2.4.1 - Diagrama simplificado do efeito estufa Fonte - Nobre (2008) (Informação pessoal) ${ }^{3}$

Parte da radiação solar é refletida pelas nuvens (20\%), pela atmosfera (6\%) e pela superfície da Terra (4\%). Da radiação solar que atravessa a atmosfera, uma parte é absorvida pela Terra (51\%), aquecendo-a. A Terra aquecida emite radiação infravermelha desde sua superfície. Essa radiação infravermelha é parcialmente absorvida e novamente remetida à atmosfera, onde fica presa em razão da presença dos gases de efeito estufa. O resultado é um aquecimento da atmosfera inferior e da superfície da Terra.

De modo geral, o modal rodoviário tem uma considerável participação nesse contexto, já que os veículos consomem combustíveis e produzem vapor d'água $\left(\mathrm{H}_{2} \mathrm{O}\right)$ e dióxido de carbono $\left(\mathrm{CO}_{2}\right)$. O óxido nitroso $\left(\mathrm{N}_{2} \mathrm{O}\right)$ também é formado em motores de combustão interna. Quanto às emissões de metano $\left(\mathrm{CH}_{4}\right)$, emitido a partir do escapamento dos veículos de combustão interna, apesar de não poderem ser quantificadas com precisão, pode-se afirmar que a proporção proveniente dos veículos automotores é significativa. O ozônio $\left(\mathrm{O}_{3}\right)$ é gerado a partir da ação entre os gases $\left(\mathrm{HC}\right.$ e $\mathrm{NO}_{\mathrm{x}}$ ) emitidos pelos veículos. Essa reação ocorre geralmente na estratosfera ativada pela luz solar.

Todos esses gases existem na natureza e são necessários para manter o equilíbrio da biosfera. Entretanto, produzidos artificialmente pela 2008, no ICMC - USP, São Carlos. 
interferência humana, em volumes que a natureza não consegue reciclar em tempo hábil, provocam danos irreversíveis e de grande proporção na atmosfera.

Os estudos relacionados ao aquecimento global concentram suas análises nas emissões de $\mathrm{CO}_{2}, \mathrm{CH}_{4}$ e $\mathrm{N}_{2} \mathrm{O}$, devotando praticamente nenhuma atenção aos gases que possuem efeito indireto, como o CO, os $\mathrm{HC}$ e os $\mathrm{NO}_{\mathrm{x}}$ (URIA; SCHAEFFER, 1997). Dispensar especial atenção a esses gases é importante, visto que causam malefícios diretamente à saúde do homem, num primeiro momento, e também indiretamente, tanto à saúde quanto ao ambiente.

\subsection{Efeitos da poluição na saúde}

Os efeitos da poluição do ar são classificados como:

- Efeitos agudos - podem ser de caráter temporário, e originam-se de episódios em que os poluentes ultrapassam os níveis regulares de sua concentração gerando efeitos imediatos como irritação nos olhos, tosse e até efeitos graves, como o aumento da mortalidade. Os efeitos são, em geral, reversíveis e ocorrem quando há condições climáticas adversas, com consequente aumento da concentração de poluentes.

- Efeitos crônicos - de caráter permanente podem ocasionar prejuízos à vegetação, à visibilidade e à saúde dos seres humanos, causando incômodos e desconforto (danos sociais). Em longo prazo, podem provocar a corrosão de estruturas e o desgaste de materiais de construções e obras de arte (DETRAN-RJ; FEEMA, 2001).

Em termos gerais, os efeitos da exposição de longo prazo ("crônicos") a baixos níveis de poluição são difíceis de serem estudados e poucos trabalhos tratam do assunto. Extrapolar a informação recebida de estudos de curto prazo a altos níveis de poluição para a exposição em longo prazo a baixos níveis é uma tarefa difícil. No caso de alguns poluentes, pode existir um limiar de concentração do poluente abaixo do qual não ocorre qualquer efeito particular à saúde. Em tais casos, as previsões obtidas, assumindo-se uma proporcionalidade direta, entre a exposição e o efeito, não poderiam ser garantidas. Ademais, podem existir efeitos à saúde que não se manifestam quando a exposição aos poluentes, mesmo intensa, ocorre apenas durante um breve período de tempo (LOUREIRO, 2005). 
O nível de exposição a qualquer poluente varia de forma considerável de local para local. Contudo, podem-se coletar informações sobre a saúde e os níveis de poluição em diferentes locais e correlacioná-las, utilizando estatística, a fim de estabelecer o efeito de um sobre o outro.

Os principais efeitos da poluição do ar na saúde humana são os problemas causados nas vias respiratórias. A maior parte desses problemas advém da presença de material particulado e de alguns gases, como o dióxido de enxofre, o monóxido de carbono e algumas substâncias organo-cloradas. Os produtos derivados de petróleo são conhecidos como indutores do câncer do rim e retardamento do sistema nervoso central.

Considerando-se que, diariamente, cerca de $12 \mathrm{~m}^{3}(15 \mathrm{~kg})$ de ar são inalados pela maioria dos indivíduos - quantidade essa que pode variar com a idade e o nível de atividade de cada pessoa -, é de se esperar que a qualidade da respiração afete o funcionamento do metabolismo celular do organismo e, portanto, a saúde do indivíduo. Os poluentes do ar entram no organismo dos seres humanos e de outros seres vivos pelo sistema respiratório, causando grandes desordens não apenas nesse sistema, pois passam dos pulmões para o sistema circulatório, afetando outras funções fisiológicas. Os efeitos tóxicos agudos dos gases de exaustão automotiva são conhecidos desde o advento das máquinas de combustão interna, que liberam quantidade de monóxido de carbono suficiente para causar a morte por intoxicação quando funcionando em ambientes fechados, tais como garagens. Por esse motivo, a emissão de $\mathrm{CO}$ foi uma das primeiras a ser alvo das regulamentações (BRAUN et al, 2004). A tabela 2.5.1 demonstra a gravidade da inalação do $\mathrm{CO}$. 
Tabela 2.5.1 - Tabela de valores de referência de níveis de periculosidade de acordo com a ASHREA

\begin{tabular}{|c|c|}
\hline Concentração de CO & Tempo de inalação e sintomas \\
\hline 9 ppm $(0,009 \%)$ & Exposição máxima permitida em curtos períodos de tempo \\
\hline 35 ppm $(0,0035 \%)$ & Máximo permitido para períodos de exposição continua até 8 horas \\
\hline 200 ppm $(0,02 \%)$ & $\begin{array}{c}\text { Ligeiras dores de cabeça, cansaço, náuseas ao fim de } 2 \text { a } 3 \text { horas de } \\
\text { exposição contínua }\end{array}$ \\
\hline 800 ppm $(0,08 \%)$ & $\begin{array}{l}\text { Tonturas, fortes náuseas e convulsões em menos de } 45 \text { minutos de } \\
\text { exposição } \\
\text { Perda de consciência ao fim de } 2 \text { horas e morte ao fim de } 3 \text { horas. }\end{array}$ \\
\hline 1600 ppm $(0,16 \%)$ & Fortes tonturas, desmaios, náuseas fortes. Morte ao fim de 1 hora \\
\hline 3200 ppm $(0,32 \%)$ & $\begin{array}{l}\text { Fortes tonturas, desmaios, náuseas fortes. Morte ao fim de } 20 \text { a } 30 \\
\text { minutos }\end{array}$ \\
\hline $6400 \mathrm{ppm}(0,64 \%)$ & Morte em menos de 15 minutos \\
\hline
\end{tabular}

Fonte - American Society Heating and Refrigeration Engineers (2006)

O CO é um gás tóxico, inodoro, incolor e fruto da combustão de diversos processos industriais, do escapamento de veículos automotores e do fumo do cigarro. A intoxicação aguda pode ser fatal. Sua toxicidade se deve em parte à sua propriedade relacionada à afinidade pela heme ${ }^{4}$ da hemoglobina e da mioglobina. O CO, quando absorvido pelo sangue, forma a carboxihemoglobina, que por sua vez produz uma diminuição da oxihemoglobina e uma redução do transporte de oxigênio até os tecidos. Possui uma afinidade de até 300 vezes maior com a hemoglobina do que o oxigênio, o que favorece a hipoxemia em pessoas expostas.

O CO foi associado ao aumento na mortalidade por infarto cardíaco agudo entre as pessoas idosas e seu efeito é mais danoso em pessoas portadoras de doenças coronárias, porque o coração tem que trabalhar mais intensamente para levar oxigênio ao corpo. Sua exposição tem sido associada também aos agravamentos de dores de angina, diminuição à tolerância a exercícios em pessoas com doenças periféricas vasculares e doenças pulmonares, prejuízo nas funções do sistema nervoso e provável risco para fetos. A exposição ao CO próximo aos níveis dos padrões de qualidade ambiental do ar pode levar a fadiga, dores de cabeça, confusão e vertigem pela falta da oxigenação. Em altitudes

\footnotetext{
${ }^{4}$ Hemo ou heme é um grupo prostético consistente de um átomo de ferro contido no centro de um largo anel orgânico heterocíclico chamado porfirina. O grupo hemo possui um átomo de ferro ferroso "FE++" para exercer a função de ligação com o oxigênio em células sanguíneas.
} 
elevadas, esse quadro é agravado. A figura 2.5.2 a seguir mostra a relação entre o ambiente contaminado e seus efeitos no corpo humano.

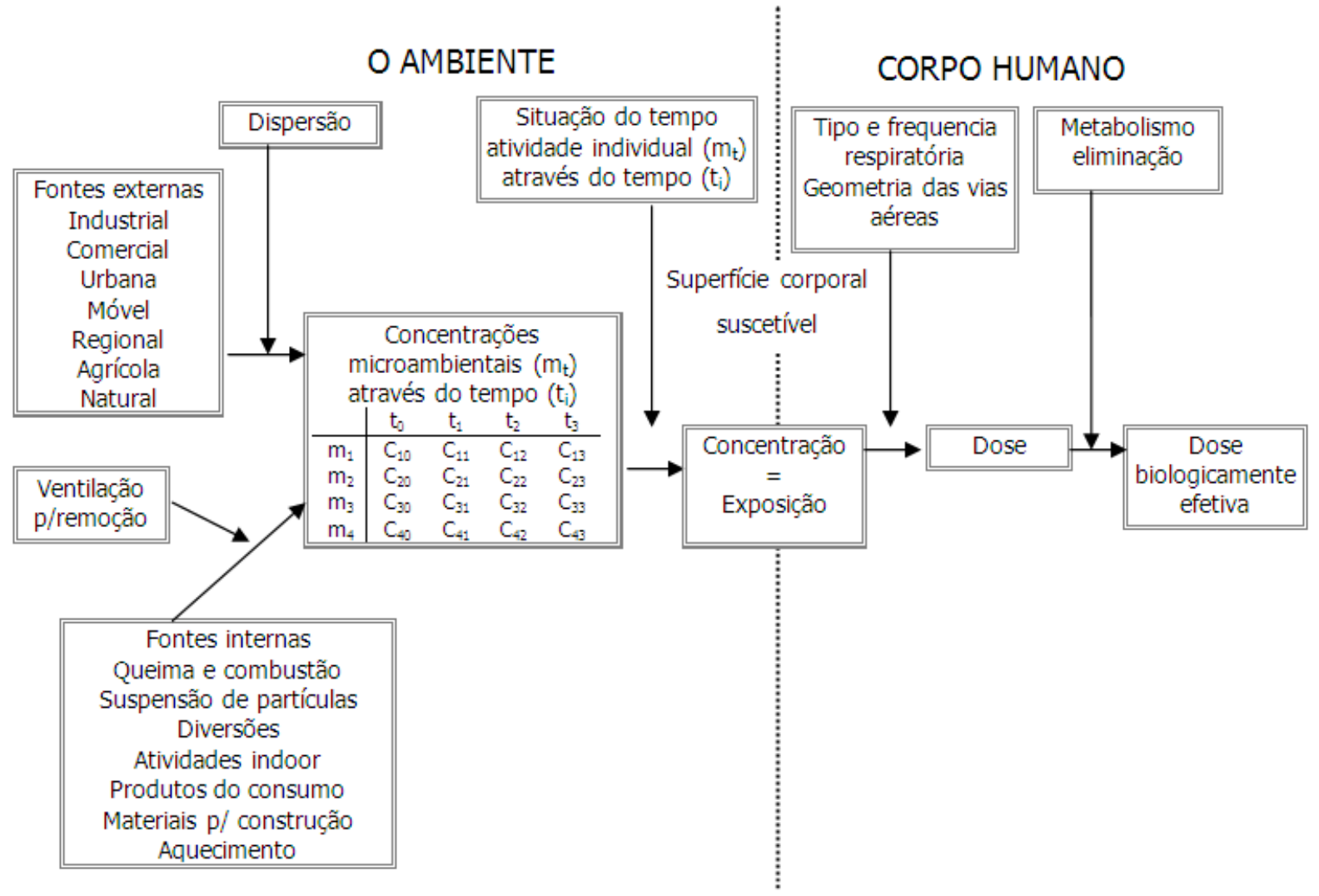

Figura 2.5.1 - $\mathrm{O}$ ambiente contaminado e o efeito no corpo humano Fonte - Castro (2003)

Segundo Bohm (2001), as doenças relacionadas às cardiopatias e às pneumopatias só aparecem associadas à poluição nos atestados de óbito emitidos em alguns países desenvolvidos. É quase impossível avaliar a real extensão das doenças relacionadas à poluição veicular em meio urbano, principalmente pela dificuldade em separar o efeito dos poluentes do ar de origem automotiva das outras fontes. A população deve ser esclarecida para saber reconhecer melhor os efeitos causados pela exposição à poluição, de modo que tenha uma consciência mais ampla e significativa das suas consequências e possa colaborar com o seu controle.

A tabela 2.5.2 mostra os principais poluentes, suas características, fontes principais, efeitos sobre a saúde e seus danos ambientais. 
Tabela 2.5.2 - Principais poluentes considerados indicadores da qualidade do ar

\begin{tabular}{|c|c|c|c|c|}
\hline Poluente & Características & Fontes principais & $\begin{array}{l}\text { Efeitos gerais sobre a } \\
\text { saúde }\end{array}$ & $\begin{array}{l}\text { Efeitos gerais ao } \\
\text { meio ambiente }\end{array}$ \\
\hline $\begin{array}{l}\text { Partículas } \\
\text { Totais em } \\
\text { Suspensão } \\
\quad \text { (PTS) }\end{array}$ & $\begin{array}{c}\text { Partículas de material } \\
\text { sólido ou líquido que ficam } \\
\text { suspensos no ar, na forma } \\
\text { de poeira, neblina, } \\
\text { aerossol, fumaça, fuligem, } \\
\text { etc. Faixa de tamanho < } \\
100 \text { micra }\end{array}$ & $\begin{array}{l}\text { Processos industriais, } \\
\text { veículos motorizados } \\
\text { (exaustão), poeira de } \\
\text { rua re-suspensa, } \\
\text { queima de biomassa. } \\
\text { Fontes naturais: } \\
\text { pólen, aerossol } \\
\text { marinho e solo }\end{array}$ & $\begin{array}{l}\text { Quanto menor o tamanho } \\
\text { da partícula, maior o efeito à } \\
\text { saúde. Causam efeitos } \\
\text { significativos em pessoas } \\
\text { com doença pulmonar, } \\
\text { asma e bronquite }\end{array}$ & $\begin{array}{c}\text { Danos à } \\
\text { vegetação, } \\
\text { deterioração da } \\
\text { visibilidade e } \\
\text { contaminação do } \\
\text { solo }\end{array}$ \\
\hline $\begin{array}{l}\text { Partículas } \\
\text { Inaláveis } \\
\left(\mathrm{MP}_{10}\right) \text { e } \\
\text { Fumaça }\end{array}$ & $\begin{array}{c}\text { Partículas de material } \\
\text { sólido ou líquido que ficam } \\
\text { suspensos no ar, na forma } \\
\text { de poeira, neblina, } \\
\text { aerossol, fumaça, fuligem, } \\
\text { etc. } \\
\text { Faixa de tamanho }<10 \\
\text { micra }\end{array}$ & $\begin{array}{c}\text { Processos de } \\
\text { combustão (indústria } \\
\text { e veículos } \\
\text { automotores), } \\
\text { aerossol secundário } \\
\text { (formado na } \\
\text { atmosfera) }\end{array}$ & $\begin{array}{c}\text { Aumento de atendimentos } \\
\text { hospitalares e mortes } \\
\text { prematuras }\end{array}$ & $\begin{array}{c}\text { Danos à } \\
\text { vegetação, } \\
\text { deterioração da } \\
\text { visibilidade e } \\
\text { contaminação do } \\
\text { solo }\end{array}$ \\
\hline $\begin{array}{l}\text { Dióxido de } \\
\text { Enxofre } \\
\left(\mathrm{SO}_{2}\right)\end{array}$ & $\begin{array}{c}\text { Gás incolor, com forte } \\
\text { odor, semelhante ao gás } \\
\text { produzido na queima de } \\
\text { palitos de fósforos. } \mathrm{Pode} \\
\text { ser transformado a } \mathrm{SO}_{3} \text {, } \\
\text { que na presença de vapor } \\
\text { de água, passa } \\
\text { rapidamente a } \mathrm{H}_{2} \mathrm{SO}_{4} \text {. É } \\
\text { um importante precursor } \\
\text { dos sulfatos, um dos } \\
\text { principais componentes } \\
\text { das partículas inaláveis }\end{array}$ & $\begin{array}{l}\text { Processos que } \\
\text { utilizam queima de } \\
\text { óleo combustível, } \\
\text { refinaria de petróleo, } \\
\text { veículos a diesel, } \\
\text { polpa e papel }\end{array}$ & $\begin{array}{c}\text { Desconforto na respiração, } \\
\text { doenças respiratórias, } \\
\text { agravamento de doenças } \\
\text { respiratórias e } \\
\text { cardiovasculares já } \\
\text { existentes. Pessoas com } \\
\text { asma, doenças crônicas de } \\
\text { coração e pulmão são mais } \\
\text { sensíveis ao } \mathrm{SO}_{2}\end{array}$ & $\begin{array}{c}\text { Pode levar à } \\
\text { formação de chuva } \\
\text { ácida, causar } \\
\text { corrosão aos } \\
\text { materiais e danos à } \\
\text { vegetação: folhas e } \\
\text { colheitas }\end{array}$ \\
\hline $\begin{array}{l}\text { Dióxido de } \\
\text { Nitrogênio } \\
\quad\left(\mathrm{NO}_{2}\right)\end{array}$ & $\begin{array}{l}\text { Gás marrom vermelhado, } \\
\text { com odor forte e muito } \\
\text { irritante. Pode levar a } \\
\text { formação de ácido nítrico, } \\
\text { nitratos (o qual contribui } \\
\text { para o aumento das } \\
\text { partículas inaláveis na } \\
\text { atmosfera) e compostos } \\
\text { orgânicos tóxicos }\end{array}$ & $\begin{array}{l}\text { Processos de } \\
\text { combustão } \\
\text { envolvendo veículos } \\
\text { automotores, } \\
\text { processos industriais, } \\
\text { usinas térmicas que } \\
\text { utilizam óleo ou gás, } \\
\text { incinerações }\end{array}$ & $\begin{array}{l}\text { Aumento da sensibilidade à } \\
\text { asma e à bronquite, abaixar } \\
\text { a resistência às infecções } \\
\text { respiratórias }\end{array}$ & $\begin{array}{l}\text { Pode levar à } \\
\text { formação de chuva } \\
\text { ácida, danos à } \\
\text { vegetação e à } \\
\text { colheita }\end{array}$ \\
\hline $\begin{array}{l}\text { Monóxido } \\
\text { de Carbono } \\
\text { (CO) }\end{array}$ & $\begin{array}{c}\text { Gás incolor, inodoro e } \\
\text { insípido }\end{array}$ & $\begin{array}{c}\text { Combustão } \\
\text { incompleta em } \\
\text { veículos automotores }\end{array}$ & $\begin{array}{c}\text { Altos níveis de CO estão } \\
\text { associados a prejuízo dos } \\
\text { reflexos, da capacidade de } \\
\text { estimar intervalos de tempo, } \\
\text { no aprendizado, de trabalho } \\
\text { e visual }\end{array}$ & \\
\hline Ozônio $\left(\mathrm{O}_{3}\right)$ & $\begin{array}{l}\text { Gás incolor, inodoro nas } \\
\text { concentrações ambientais } \\
\text { e o principal componente } \\
\text { da névoa fotoquímica }\end{array}$ & $\begin{array}{c}\text { Não é emitido } \\
\text { diretamente à } \\
\text { atmosfera É } \\
\text { produzido } \\
\text { fotoquimicamente } \\
\text { pela radiação solar } \\
\text { sobre os óxidos de } \\
\text { nitrogênio e } \\
\text { compostos orgânicos } \\
\text { voláteis }\end{array}$ & $\begin{array}{l}\text { Irritação nos olhos e vias } \\
\text { respiratórias, diminuição da } \\
\text { capacidade pulmonar. } \\
\text { Exposição a altas } \\
\text { concentrações pode resultar } \\
\text { em sensações de aperto no } \\
\text { peito, tosse e chiado na } \\
\text { respiração. } \mathrm{O}_{3} \text { tem sido } \\
\text { associado ao aumento de } \\
\text { admissões hospitalares }\end{array}$ & $\begin{array}{l}\text { Danos às colheitas, } \\
\text { à vegetação } \\
\text { natural, plantações } \\
\text { agrícolas; plantas } \\
\text { ornamentais }\end{array}$ \\
\hline
\end{tabular}

Fonte - Cavalcante (2003)

\title{
2.6 Histórico e experiências internacionais
}

\author{
Os Programas de Inspeção/Manutenção (I/M) encontram-se
} implantados em diversos países. Esses Programas foram introduzidos nos EUA no 
final dos anos 70 em resposta às discrepâncias entre as emissões de veículos novos, apresentadas nos certificados, e as emissões dos veículos em uso (HARRINGTON; McCONNELL; ANDO, 2000).

Em um típico programa de $\mathrm{l} / \mathrm{M}$, os motoristas precisam periodicamente levar seus veículos sujeitos a regulamentação a um posto de inspeção, onde um ou mais testes são realizados nos sistemas de controle de emissões dos veículos. Aos veículos que são reprovados na inspeção, é solicitado que sejam reparados e re-inspecionados. Na maioria dos programas, é exigido que os veículos passem por inspeção válida por um ou dois anos. Depois disso, os proprietários precisam retornar aos postos de inspeção para a renovação (HARRINGTON; McCONNELL; ANDO, 2000).

De acordo com Dubeux, [2006?], os programas de I/M para controle das emissões em carros em uso é um complemento essencial para padrões de emissão em novos veículos. Apesar da dificuldade de implementação, uma inspeção efetiva e um programa de manutenção pode reduzir significativamente as emissões dos veículos não controlados. Programas de I/M também são necessários para assegurar que os benefícios das tecnologias de controle nos veículos novos não estão sendo perdidos pela manutenção insatisfatória e por adulterações nos controles de emissão. Os programas de I/M para veículos a gasolina comumente incluem medidas das concentrações dos $\mathrm{HCs}$ e $\mathrm{CO}$, que são expelidos pelo escapamento. Esses programas têm uma efetividade limitada, mas podem identificar funcionamentos grosseiramente falhos nos sistemas de controle de emissões.

Há dois tipos principais de programas de I/M: programas centralizados, em que todas as inspeções são feitas em instalações de teste operadas pelo governo ou controladas entre operadoras privadas competitivamente selecionadas e programas descentralizados, em que ambos os testes de emissões e reparos são feitos em estabelecimentos privados. Programas descentralizados costumam ser menos eficazes, devido a fraudes e inspeções inadequadas. Programas centralizados operados por empresas privadas rendem melhores resultados e são recomendados para a maioria dos países em desenvolvimento. Os programas de I/M representam parte importante dos esforços para controle das emissões veiculares.

Para assegurar que os avanços nos sistemas de controle de emissões instalados nos veículos modernos continuem operando apropriadamente, 
os programas de I/M são agora encontrados na maioria das cidades em vários países do mundo (HARRINGTON; McCONNELL; ANDO, 2000).

Apresentam-se, adiante, as experiências históricas e os programas internacionais existentes, no que se refere à redução das consequências dos poluentes em escala urbana, nos Estados Unidos e na União Européia, grandes emissores de gases poluentes, a respeito dos quais foi possível encontrar dados. Também apresentam-se dados referentes ao Chile e à Argentina, países da América do Sul, que podem ser comparados aos dados brasileiros.

\subsubsection{Estados Unidos}

Segundo Dubeux, [2006?], os programas de I/M foram introduzidos nos EUA no final dos anos $70 \mathrm{em}$ resposta às discrepâncias entre as emissões de veículos novos, apresentadas nos certificados, e as emissões dos veículos em uso. Após uma década de experiência concluiu-se que os primeiros programas norte-americanos não obtiveram resultados importantes, afetando muito pouco a redução das emissões. Devido a este fato, a emenda do Clean Air Act, de 1990, atribuiu à Agência de Proteção Ambiental dos EUA (EPA) a responsabilidade de desenvolver um programa de I/M mais eficiente do que os que vinham sendo implementados, sendo mandatário em todas as áreas metropolitanas com problemas de poluição atmosférica relacionados às emissões veiculares.

Os veículos usados emitem de três a quatro vezes mais poluentes que o permitido pelos padrões de veículos novos nos EUA. Os fabricantes foram obrigados a satisfazer a padrões rigorosos de emissão de poluentes nos veículos novos. Portanto, a manutenção correta nos veículos é necessária para que as vantagens ambientais obtidas com a implementação da nova tecnologia sejam mantidas.

Em 1992, a EPA estabeleceu novas regulamentações para melhorar esse tipo de programa. Essas regulamentações foram aplicadas em algumas áreas metropolitanas com altas concentrações de ozônio $\left(\mathrm{O}_{3}\right)$ e de monóxido de carbono (CO). Cabe acrescentar, entretanto, que os governos estaduais e locais não são obrigados a implementar o programa de I/M estabelecido pela EPA. Mesmo assim, diversos estados aderiram ao Programa, que se tornou uma referência internacional. 
Dependendo da sofisticação do programa de I/M, as emissões de hidrocarbonetos $(\mathrm{HC})$ e de monóxido de carbono (CO) podem ser reduzidas de $5 \%$ a $30 \%$. Um programa abrangente de I/M pode ainda reduzir as emissões de óxidos de nitrogênio $\left(\mathrm{NO}_{\mathrm{x}}\right)$ em até $10 \%$. A execução desses programas pode se dar de duas formas a nível estadual, e o custo médio dos testes varia de US\$10 a US\$20: ou os postos de testes de inspeção são estaduais e os reparos são feitos em oficinas particulares; ou empresas privadas, contratadas pelo governo, são responsáveis pela realização dos testes de inspeção e pelos reparos.

Os testes realizados pelos programas de I/M podem ser de dois tipos basicamente:

1. Teste básico: testa as emissões de escapamento dos veículos (emissões de exaustão). Uma sonda é inserida dentro do escapamento enquanto o veículo trabalha em marcha lenta (de 600 RPM a 1.200 RPM) e com o motor em rotação de 2.500 rpm. Os analisadores de emissão, então, medem os níveis dos poluentes na exaustão. Os poluentes aqui são medidos em concentração nos gases de escapamento (\% ou PPM).

2. Teste avançado: o procedimento verifica se os componentes do sistema de controle de emissão de poluentes estão presentes e em operação. Esse teste verifica ainda as emissões evaporativas de HC. O teste avançado, ou de alta tecnologia, consiste de três testes distintos realizados nos veículos, são eles:

a) teste de emissão de escapamento, cujo resultado é fornecido em unidade de massa de poluente emitido por distância percorrida (por exemplo, g CO/km) e é realizado num regime transiente (não só em marcha lenta e a $2.500 \mathrm{rpm})$.

b) teste evaporativo de canister (purge flow test).

c) teste do sistema evaporativo (pressure test).

Os testes avançados ainda medem o consumo específico dos veículos e a economia de combustível. O teste é realizado com um dinamômetro, através de um ciclo de diferentes velocidades e acelerações, para simular a dirigibilidade em uma cidade. A aceleração e desaceleração de um veículo são as grandes fontes de emissões de poluentes em veículos sem a manutenção apropriada. O teste básico só mede as emissões de HC no escapamento, entretanto as falhas no sistema de purga e no canister evaporativo são responsáveis por grande parte das emissões de HC. 
De acordo com Dubeux, [2006?], um dos avanços do programa norte-americano foi a obrigatoriedade de realizarem testes de dinamômetro, muito mais eficientes em termos de análise das emissões veiculares do que outros testes realizados anteriormente. A EPA desenvolveu um teste sofisticado e oneroso que inclui analisadores automáticos e dinamômetro. O teste com dinamômetro IM240 simula uma operação veicular considerando velocidade e condições de aceleração similares aos realizados pelos veículos no dia a dia. Além disso, esse tipo de teste pode medir as emissões de óxidos de nitrogênio (NOx), hidrocarbonetos (HC) e monóxido de carbono (CO), em termos de taxas de emissões propriamente ditas. Os testes anteriores permitiam, apenas, a medição das concentrações dos poluentes.

Cabe acrescentar que, segundo a EPA (2003), os testes de sensoriamento remoto (os veículos são averiguados enquanto estão passando por pontos específicos das ruas onde os equipamentos são instalados) não substituem os programas de $\mathrm{I} / \mathrm{M}$, sendo eficiente como complementação, uma vez que apresentam séria limitação: nem todos os veículos são analisados e o teste não consegue captar as emissões evaporativas, uma fonte importante de emissões.

Outro avanço no programa norte-americano foi a separação de oficinas de manutenção e reparo de veículos daquelas que realizam as inspeções de emissões. A maior parte dos programas existentes era descentralizada. Oficinas privadas eram certificadas para a realização de testes e consertos nos veículos. Tal fato facilitava diversas deficiências, como aprovações não merecedoras objetivando atrair o cliente à oficina ou reprovações sem necessidade com o objetivo de vender o conserto, entre outras. Cabe acrescentar que muitos estados norte-americanos disponibilizam uma relação de oficinas para os reparos solicitados pelas inspeções com um nível de qualidade satisfatório. Além disso, a maior parte dos estados possui programas para ajudar proprietários de veículos que não têm condições de custear o reparo.

Devido aos diversos protestos de governos locais, depois das eleições de 1994, o Congresso de maioria republicana exigiu que a EPA flexibilizasse os tipos de programas, liberando-os para a implantação de programas locais. Mesmo assim, diversos estados norte-americanos optaram pela implantação do programa desenvolvido pela EPA, inclusive utilizando o teste IM240. 


\subsubsection{União Européia}

Segundo Dubeux, [2006?], em diversos países da União Européia existem os testes de emissão veicular a aproximadamente 20 anos. Entretanto, originalmente eram incluídos apenas caminhões, ônibus, táxis e ambulâncias. A diretriz estabelecia a lista de itens a serem inspecionados, como freios e emissões, mas não determinava padrões a serem seguidos, critérios e métodos de testes.

Posteriormente, o programa foi revisado e padrões foram estabelecidos para alguns países membros. Para outros, os testes já executados há muito tempo foram apenas reafirmados. Desde 1977, as diretrizes dos programas de I/M dos países da União Européia foram modificadas diversas vezes e, atualmente, incluem, também, automóveis e vans leves. Além disso, os critérios dos testes de emissões foram detalhados e padronizados. O sistema como um todo e todas as suas emendas foram consolidados no Directive 96/96/EC. Cabe reiterar que esta diretriz foi implantada visando a uma padronização dos testes, frequências e aspectos de obrigatoriedade, objetivando uma mínima qualidade, já que estes variavam entre cada país-membro, prejudicando a segurança e o meio ambiente de alguns países. Cada país membro poderá realizar testes mais rigorosos, caso considere oportuno.

Os testes nos países-membro deverão ser realizados pelo Estado, por corporações públicas de confiança do Estado, ou por corporações e/ou estabelecimentos designados para efetuar os testes, supervisionados diretamente pelo Estado, incluindo corporações privadas autorizadas. Em particular, quando estabelecimentos designados como centros de testes de veículos também efetuam reparos nos motores, os países-membro deverão assegurar, da melhor maneira possível, a qualidade necessária aos testes.

A frequência mínima de inspeção para os automóveis e os veículos leves comerciais é de dois anos, iniciando-se a partir do quarto ano de uso do veículo, mas a grande parte dos programas de I/M dos países-membro exige uma frequência maior. Cabe acrescentar que a França, Irlanda, Portugal e Itália começaram seus programas de I/M para automóveis somente em 1998. A Tabela 2.6.2.1 apresenta a frequência exigida nos testes para os países-membro da Comunidade Européia. 
Tabela 2.6.2.1 - Veículos subordinados à inspeção e sua frequência

\begin{tabular}{|c|c|}
\hline Categorias de veículos & Frequência dos testes \\
\hline $\begin{array}{l}\text { Veículos automotores para transporte de } \\
\text { passageiros com mais de oito lugares, } \\
\text { excluindo o do motorista }\end{array}$ & $\begin{array}{l}\text { Um ano após a data em que o veículo foi } \\
\text { utilizado pela primeira vez e, a partir de } \\
\text { então, anualmente }\end{array}$ \\
\hline $\begin{array}{l}\text { Veículos automotores usados para o } \\
\text { carregamento de produtos com um limite } \\
\text { de peso máximo excedendo } 3.500 \mathrm{~kg}\end{array}$ & $\begin{array}{l}\text { Um ano após a data em que o veículo foi } \\
\text { utilizado pela primeira vez e, a partir de } \\
\text { então, anualmente }\end{array}$ \\
\hline $\begin{array}{l}\text { Trailers e semi-trailers com um limite de } \\
\text { peso máximo excedendo } 3.500 \mathrm{~kg}\end{array}$ & $\begin{array}{l}\text { Um ano após a data em que o veículo foi } \\
\text { utilizado pela primeira vez e, a partir de } \\
\text { então, anualmente }\end{array}$ \\
\hline Táxis e ambulâncias & $\begin{array}{l}\text { Um ano após a data em que o veículo foi } \\
\text { utilizado pela primeira vez e, a partir de } \\
\text { então, anualmente }\end{array}$ \\
\hline $\begin{array}{l}\text { Veículos automotores com, no mínimo } \\
\text { quatro rodas, normalmente utilizados } \\
\text { para carregamento rodoviário de produtos } \\
\text { e com um limite de peso máximo não } \\
\text { excedendo } 3.500 \mathrm{~kg} \text {, excluindo tratores } \\
\text { de agricultura e máquinas }\end{array}$ & $\begin{array}{l}\text { Quatro anos após a data em que o } \\
\text { veículo foi utilizado pela primeira vez e, a } \\
\text { partir de então, de dois em dois anos }\end{array}$ \\
\hline $\begin{array}{l}\text { Veículos automotores com, no mínimo } \\
\text { quatro rodas, utilizados para o transporte } \\
\text { de passageiros e com não mais de oito } \\
\text { lugares, excluindo o do motorista }\end{array}$ & $\begin{array}{l}\text { Quatro anos após a data em que o } \\
\text { veículo foi utilizado pela primeira vez e, a } \\
\text { partir de então, de dois em dois anos }\end{array}$ \\
\hline
\end{tabular}

Fonte - Dubeux, [2006?]

Exige-se que seja testado nos veículos o conteúdo de monóxido de carbono (CO) das emissões de poluentes, com o limite de 3,5\% ou $4,5 \%$, dependendo da idade do veículo, ou como resposta aos valores mais restritivos ofertados pela indústria. Em outras palavras, o máximo permitido de conteúdo de monóxido de carbono nos gases emitidos é aquele estipulado pelo fabricante. Caso essa informação não esteja disponível ou caso as autoridades dos países-membro decidam não utilizá-la como valor de referência, o conteúdo CO não poderá exceder os seguintes limites:

- Os veículos registrados ou utilizados pela primeira vez entre março de 1970 e primeiro de outubro 1986 devem cumprir o Directive 70/220/EEC, onde o limite de CO é de $4,5 \%$ de volume.

- Para veículos registrados ou utilizados pela primeira vez depois de primeiro de outubro de 1996, o limite de CO é de 3,5\% de volume.

O conteúdo de monóxido de carbono das emissões de veículos com sistemas avançados de controle de emissões, por exemplo, com catalisadores 
de três vias é, desde 1997, testado, sendo exigido um limite de $0,3 \%$ no caso do teste com alta velocidade. A razão ar/combustível também é testada.

Os veículos a diesel precisam ser testados, verificando a opacidade da fumaça de exaustão. $O$ teste é executado a partir de uma aceleração livre do veículo. O teste se tornou obrigatório a partir de 1996.

No caso dos veículos pesados, além da inspeção anual, a proposta da União Européia é que sejam realizadas inspeções surpresas nas ruas, tanto para analisar aspectos de segurança quanto de meio ambiente.

Foi elaborado um estudo pelo "Grupo de Trabalho 4 - Inspeção e Manutenção" da Comissão Européia, visando analisar as inspeções de I/M. A seguir são apresentadas as principais conclusões do estudo:

- Veículos com catalisadores de três vias: o teste regular identificou apenas $15 \%$ dos veículos como poluentes e resultou em apenas $5 \%$ de redução das emissões de poluentes comparados a um cenário sem I/M. Um programa de I/M apropriado utilizando transient short tests cycles poderia reduzir as emissões de poluentes em $35 \%$ no caso de $\mathrm{CO}, 25 \%$ para $\mathrm{HC}$ e $5 \%$ para NOx.

- Veículos sem catalisadores ou com catalisadores oxidados: o estudo concluiu que os testes foram bastante eficientes, com, por exemplo, um potencial de redução de $15 \%$ das emissões de $\mathrm{CO}$. A redução do limite de 3,5\% para 1,5\% deverá resultar em ganhos futuros adicionais.

- Veículos a diesel: os tipos de teste utilizados obtiveram os mesmos resultados em termos de eficiência, um potencial de redução de, aproximadamente, 25\% em material particulado (MP) para todos os pequenos testes. Entretanto, poderá ter ocorrido uma superestimação devido ao fato de a amostra ter focado veículos com altos valores de emissão. Cabe acrescentar, entretanto, que devido ao fato de as partículas ultrafinas estarem sendo cada vez mais foco de atenção e de que os tratamentos voltados a eliminar fumaça visível são cada vez mais utilizados, os testes de opacidade poderão se tornar obsoletos. Estudos estão sendo realizados com o objetivo de estabelecer técnicas para medição de poluentes de veículos a diesel com baixas emissões.

- Sensoriamento remoto: esse tipo de teste pode medir as emissões de um grande número de veículos sem inconvenientes para o motorista, além de ser 
um sistema automatizado, com necessidade de pouquíssima mão-de-obra. Com base em dados da Inglaterra e Grécia, o uso desse tipo de teste, estabelecendo-se o limite de $5 \%$ do volume de CO, pode reduzir as emissões de, aproximadamente, $5 \%$ e $25 \%$ dos veículos (EUROPEAN COMMISSION, 2006). Através dos testes de sensoriamento remoto, foi observado que o número de veículos encontrados com emissão excessiva de poluentes vinha demonstrar que a inspeção regular, bianual, não foi suficiente para assegurar a não deterioração significativa desses, entre os períodos dos testes. $O$ estudo concluiu que os testes de sensoriamento remoto seriam eficientes para complementar as $\mathrm{I} / \mathrm{M}$ regulares minimizando os efeitos da falta de manutenção dos veículos e deterioração da qualidade do ar. Entretanto, cabe acrescentar que os veículos mais novos, além de emitirem menos, provavelmente são mais estáveis em termos de emissão.

Concluiu-se, por outro lado, que os testes de dinamômetro são mais eficientes, além de ser o único método que mensura as emissões de óxidos de nitrogênio. No caso dos veículos a diesel, esses testes também são recomendados. Uma questão importante, ressaltada pelos estudos europeus, é se as inspeções veiculares, com testes de dinamômetro, continuarão sendo proveitosas, já que os veículos nos próximos anos terão sistemas On Board Diagnoses - OBD. No caso dos veículos pesados, os testes mais tradicionais de $\mathrm{l} / \mathrm{M}$, incluindo teste no dinamômetro, não são viáveis, sendo que o grande avanço dos programas de I/M nesse caso será a introdução de OBD e, talvez, o desenvolvimento de técnicas de sensoriamento remoto para veículos a diesel (para medição de emissões de NOx e particulados).

Ressalte-se que os efeitos reais de qualquer programa de I/M dependem diretamente da frequência das inspeções periódicas. Mas, estudos europeus indicam que não é evidente o conhecimento sobre o que ocorre com as emissões dos veículos durante os intervalos das inspeções. Além disso, segundo os estudos europeus, o sistema OBD, provavelmente, não será custo-efetivo no curto e médio prazo, devido aos seguintes fatos:

- Na Europa os sistemas OBD somente serão difundidos após 2005 e serão universais apenas após 2010, sendo que os veículos a diesel demorarão mais, aproximadamente, cinco anos depois dos de gasolina; 
- Os sistemas OBD somente monitoram os excessos sobre os limites mínimos, que podem ser considerados maiores que os limites dos certificados;

- O sistema pode apresentar falhas após os $80.000 \mathrm{~km}$ rodados e também ficar temporariamente desativado em várias circunstâncias.

Se o sensoriamento remoto for utilizado para detectar somente os veículos mais poluentes e a seleção for realizada com base em detecções múltiplas (o veículo é detectado em mais de uma passagem), a eficiência por veículo detectado pode ser alta. Dependendo do nível de manutenção da frota, este método pode ser eficiente. Segundo os estudos, se este método for utilizado para detectar os veículos que emitem apenas um pouco mais que o limite estabelecido, pode ocorrer erros no sistema. Em outras palavras, o sistema de sensoriamento remoto funciona relativamente bem para detectar veículos com altos níveis de emissão.

As tabelas 2.6.2.2 e 2.6.2.3 mostradas a seguir apresentam as emissões antes e depois da implementação de alguns programas de I/M, assim como a redução percentual obtida para cada tipo de poluente.

Tabela 2.6.2.2 - Comparação das reduções de emissões estimadas pela EPA e levantadas

\begin{tabular}{|c|c|c|c|}
\hline & $\begin{array}{c}\text { Emissões antes do programa } \\
\text { de I/M (Testes Avançados) } \\
\text { (g/milha) }\end{array}$ & $\begin{array}{l}\text { Emissões depois da } \\
\text { implementação do programa } \\
\text { avançado de } \mathrm{l} / \mathrm{M} \text { (g/milha) }\end{array}$ & $\begin{array}{l}\text { Redução das } \\
\text { emissões de } \\
\text { poluentes (\%) }\end{array}$ \\
\hline \multicolumn{4}{|c|}{ Estimativa EPA } \\
\hline $\mathrm{HC}$ total * & 1,96 & 1,27 & 35 \\
\hline HC exaustão & 0,88 & 0,59 & 33 \\
\hline $\mathrm{CO}$ & 10,9 & 6,67 & 39 \\
\hline $\mathrm{NO}_{\mathrm{x}}$ & 0,89 & 0,83 & 7 \\
\hline \multicolumn{4}{|c|}{ Programa I/M do Arizona } \\
\hline $\mathrm{HC}$ ** & 0,81 & 0,70 & 13 \\
\hline $\mathrm{CO}$ & 12,2 & 10,6 & 13 \\
\hline NOx & 1,5 & 1,38 & 8 \\
\hline
\end{tabular}

Fonte - Harrington ; McConnell e Ando (2000)

* o total de HC contabiliza as emissões evaporativas, além das emissões de escapamento.

${ }^{* *}$ não considera as emissões evaporativas. 
Tabela 2.6.2.3 - Redução das emissões de poluentes dos programas de I/M da Suécia e da Suíça

\begin{tabular}{|c|c|}
\hline \multicolumn{2}{|c|}{ Redução das emissões de poluentes (\%) } \\
\hline \multicolumn{2}{|c|}{ Suécia } \\
\hline CO & 20 \\
\hline HCs & 7 \\
\hline & Suíça \\
\hline CO & $20-30$ \\
\hline HCs & $20-30$ \\
\hline Fonte - Faiz; Weavert e Walsh (1998) \\
\hline
\end{tabular}

Fonte - Faiz; Weavert e Walsh (1998)

\subsubsection{Argentina}

$\mathrm{Na}$ Argentina, o programa teve início em 1991. A regulamentação é federal, mas, cada província pode adaptar as características do programa às suas condições específicas, como por exemplo, no estabelecimento do período de isenção inicial para veículos novos (três anos na Lei Federal) e na periodicidade da inspeção. Consequentemente pode haver diferenças entre os programas das diversas províncias. Atualmente, cerca de $75 \%$ da frota do país, estimada em 7 milhões de veículos, é submetida periodicamente às inspeções técnicas.

Hoje, a Província de Buenos Aires é a única que possui um sistema completo de controle da frota em circulação. Para coordenar as ações do programa foi criado o Ente Regulador de la Verificación Vehicular, que tem como missão assegurar a qualidade do serviço prestado pelas concessionárias e zelar para que o usuário, que paga pelo serviço, receba uma correta e satisfatória atenção.

A Província foi dividida em 11 empresas concessionárias, com prazo de contrato de 20 anos. Cada proprietário deve, obrigatoriamente, realizar a inspeção de seu veículo no local onde ele está registrado. A política de preços aos usuários é fixada pelo governo, sendo única em toda a província por categoria de serviço. Cabe ressaltar que as concessionárias estão impedidas de realizar quaisquer reparos no veículo, com exceção à regulagem de motores de veículos carburados.

$\mathrm{O}$ atendimento de áreas remotas com baixa densidade de veículos é realizado por estações móveis. Além disso, o controle do trânsito - 
sinalização, operação e fiscalização, são de responsabilidade dos governos municipais.

Cada linha de inspeção na Argentina possui um manual de procedimentos padrão, que abrange itens de inspeção, equipamentos e classificação dos defeitos. Os equipamentos exigidos em uma linha são: analisador de gases, opacímetro, decibelímetro, frenômetro, banco de suspensão, placa de alinhamento de direção, regloscópio, placas de verificação de folgas, e elevador (ou fossa de inspeção).

No início do controle, houve um enorme índice de reprovação dos veículos, com a exigência do cumprimento pleno do manual de procedimentos. Nessa ocasião, 8 em cada 10 veículos foram reprovados. Em face da inviabilidade de sustentação dessa situação, foi introduzida pelo Ente Regulador uma flexibilidade na exigência das disposições do manual. Esses critérios são revistos periodicamente, com o aumento do rigor exigido na inspeção. As inspeções são realizadas por técnicos em veículos automotores, formados em escolas técnicas. A seleção e o treinamento dos técnicos são de responsabilidade de cada concessionária. O treinamento não possui um sistema de credenciamento ou certificação por parte do Ente Regulador, apenas um cadastro atualizado de todos os inspetores. A responsabilidade técnica do programa deve ser de um engenheiro. Quanto aos aspectos operacionais, a configuração de uma linha de inspeção, abrangendo a disposição de equipamentos e o número e a distribuição de inspetores é uma tecnologia de cada empresa.

Na Argentina, o custo médio estimado para a instalação de uma estação, é de US\$ 3 milhões. Os benefícios gerais decorrentes do programa, apontados pelo estudo, foram:

- Benefícios para a comunidade: menor sinistralidade; menor contaminação atmosférica; menores custos hospitalares e de atendimento de emergências; novos postos de trabalho diretos e indiretos; economia de fontes de energia não renováveis;

- Benefícios para o Estado: preservação da segurança viária e do meio ambiente; recebimento de impostos diretos e indiretos; recebimento da taxa de concessão; criação de um banco de dados da frota; redução da evasão de arrecadação relativa à frota; 
- Benefícios para o proprietário: segurança própria e da família; menos consumo de combustível; maior valor de revenda do veículo; diagnóstico do veículo e menores custos de reparação; menores custos com seguros.

O Ente Regulador controla o programa através da execução de visitas mensais às estações e de outras não programadas, onde são observados tanto os procedimentos técnicos associados à inspeção de veículos propriamente dita como os aspectos administrativos da estação. Além disso, há uma inspeção semestral para verificação da calibração dos equipamentos.

Como no Rio de Janeiro, no caso a Feema (Fundação Estadual de Engenharia do Meio Ambiente), o Ente Regulador recebe as informações geradas em cada estação e analisa estatisticamente os dados. Além disso, da mesma forma que no Rio de Janeiro, o controle do sistema em Buenos Aires é complementado por fiscalizações aleatórias na via pública, exercidas pela polícia, onde são identificados veículos fora das condições de uso, mesmo tendo passado pelas inspeções, e veículos que não se apresentaram à inspeção.

O estudo apontou algumas falhas do programa argentino, como por exemplo, apesar de o programa ser instalado na maior parte do país, ainda existe grandes áreas descobertas. Essa situação gera conflitos com a migração da frota, seja na alteração da localidade de registro para ficar dispensado da vistoria, seja para aqueles veículos reprovados, que assim são comercializados em áreas sem controle. Além disso, o sistema ainda não exige o cumprimento pleno da legislação de trânsito, em face da avançada idade média da frota e da impossibilidade de reparação completa de toda a frota no curto prazo. O programa argentino se encontra em fase de consolidação.

\subsubsection{Chile}

O programa de I/M do Chile foi regulamentado em 1990 na sua concepção atual, a qual prevê avaliações por instrumentos e integradas. O programa foi instalado em 1997, abrangendo quatro das treze zonas administrativas e atingindo significativa parcela da frota do país de 1,5 milhões de veículos. Nas demais zonas, há um controle visual da frota circulante.

A região metropolitana de Santiago possui um sistema completo de inspeções. A Cidade de Santiago, abrangendo os municípios vizinhos, 
é a região do país mais crítica em termos de contaminação atmosférica, principalmente em decorrência do grande número de veículos em circulação, aproximadamente 75.000. Essa situação é agravada pelas condições climáticas e pelo relevo da região, dificultando a dispersão de gases poluentes.

No Chile, o responsável pela condução do programa de I/M é o Ministério dos Transportes e Telecomunicações. Existe uma concessão para os serviços em cada uma daquelas quatro zonas administrativas onde seus sistemas de inspeção veicular são mecanizados. Houve uma subdivisão da região em quatro áreas (Oriente, Centro/Norte/Ocidente, Sul/Ocidente e Sul). O sistema é de livre concorrência, com preços livres, desde que sejam respeitados os limites máximos estabelecidos na licitação e no contrato de concessão. Os prazos de concessão estabelecidos nos contratos em andamento são de cinco anos, a partir da formalização do contrato, podendo ser prorrogados por mais dez meses.

Segundo o estudo, a regulamentação estabelece uma periodicidade de inspeção de acordo com a categoria e o uso do veículo:

- Táxis, ônibus e caminhões, a inspeção tem uma validade de seis meses;

- Frota particular tem inspeção anual, com uma isenção inicial que varia de 24 a 36 meses.

Cabe ressaltar que, com o objetivo de assegurar a independência e isenção na inspeção, no processo seletivo das concessionárias houve restrição à participação de empresas que pudessem enviesar as análises. Diante desse fato, empresas relacionadas ao setor automotivo, tais como montadoras, importadoras, concessionárias, oficinas, frotistas, empresas de transporte, entre outros, estão excluídos do sistema. As concessionárias estão impedidas de realizar quaisquer intervenções no veículo.

O mínimo de equipamentos exigido em uma linha de inspeção é: aparelho para verificação da pressão dos pneus, compressor de ar, profundímetro, frenômetro de rolos, medidor do alinhamento de rodas, banco de prova de suspensão, detector de folgas, analisador de gases, opacímetro, regloscópio com luxímetro, macaco com capacidade mínima de cinco toneladas e 
medidor da verificação do ângulo de giro (os dois últimos somente para veículos denominados tipo $\mathrm{A} 2^{5}$ ).

A responsabilidade técnica do programa por parte de cada concessionária é de um engenheiro civil mecânico ou civil industrial, o que equivale a um engenheiro mecânico pleno no Brasil. Em cada estação de inspeção, o responsável deve ser um engenheiro de execução mecânico, equivalente a um tecnólogo ou engenheiro operacional no Brasil. Os inspetores do programa devem ser técnicos de nível secundário na especialidade de mecânica, ou com comprovação de desempenho de atuação como mecânico. Segundo o estudo, a configuração básica de uma linha de inspeção abrange três estágios: inspeções visuais (fossa de inspeção), inspeções mecanizadas (frenômetro, banco de suspensão, alinhamento) e inspeções de emissões e de luzes.

As informações das inspeções visuais são introduzidas no sistema informatizado por meio de digitação dos códigos dos defeitos. Os dados resultantes das inspeções realizadas são armazenados em cada estação e são enviados diariamente para uma empresa que procede a consolidação das informações e, posteriormente, as envia ao Ministério responsável.

As tarifas por categoria de veículo são as definidas na proposta da concessionária e no contrato de concessão. Assim, os preços são diferentes nas estações de cada concessionária. De acordo com Dubeux, [2006?,] o valor médio de uma inspeção em veículo leve é de, aproximadamente, US\$21,50 e de um ônibus, aproximadamente US\$39,30.

Segundo o estudo, os índices de reprovação relativos aos veículos leves no Chile variam de $25 \%$ a $30 \%$. Os principais motivos de reprovação são as emissões de gases e de luzes. Para os táxis e veículos de transporte escolar, o índice de reprovação é de $40 \%$, sendo os principais motivos as emissões e os freios. Cabe ressaltar que, no caso dos ônibus, devido à elevada idade média da frota, o índice de reprovação atinge $80 \%$, sendo os principais motivos de reprovação às emissões de gases, o sistema de direção e a carroceria. Ou seja, as emissões sempre aparecem como principais motivos de reprovação, o que mostra a importância dos programas de l/M.

\footnotetext{
${ }^{5}$ Veículos médios e pesados de passageiros com mais de nove assentos, veículos médios e pesados de carga com capacidade maior de $1.750 \mathrm{~kg}$, táxis, veículos de auto-escolas, veículos de transporte escolar, reboques e semi-reboques e máquinas.
} 
A partir do início do programa, houve uma significativa renovação da frota, principalmente pela obrigação de inspeções frequentes para os veículos com tecnologia mais antiga, sem catalisadores. Cabe ressaltar que, segundo os autores, não há estudos consistentes relacionados à redução de poluição atmosférica decorrente do programa de l/M.

O programa de I/M do Chile engloba auditorias do Ministério, através de inspeções regulares às estações, periódicas, programadas e aleatórias. Nessas inspeções, são verificados os cumprimentos dos procedimentos técnicos e administrativos do programa assim como as calibrações dos equipamentos. Por fim, o programa chileno ainda não exige o cumprimento pleno da legislação de trânsito no instante da inspeção, ficando o usuário notificado da existência de eventuais defeitos menores, que deverão ser obrigatoriamente reparados.

Além disso, na concepção atual, que inclui verificações mecanizadas e sistematizadas, o programa chileno está implantado nas principais regiões do país, mas existem grandes áreas não cobertas pelo programa de inspeções mecanizadas, sendo exercida apenas inspeção visual nessas regiões.

\subsubsection{Brasil}

O sistema de transportes brasileiro se fundamenta em malhas viárias, expandidas e melhoradas na última década por meio de investimentos governamentais diretos ou procedentes de um amplo processo de privatização. Foram concedidas ao setor privado a operação e a modernização de rodovias. Segundo dados da Cetesb (2008) o número de veículos em circulação no Brasil passou de 3 milhões, em 1970, para cerca de 29 milhões, em 2001, 68\% constituídos por automóveis. Em 2007, foram realizados 2.462.728 emplacamentos de automóveis segundo dados da Anfavea (Associação Nacional dos Fabricantes de Veículos Automotores).

$\mathrm{Na}$ região metropolitana de São Paulo, circulam, atualmente, quase sete milhões de veículos, para uma população aproximada de 17,8 milhões de habitantes, uma das mais elevadas taxas de motorização do mundo. As dificuldades de circulação urbana são atribuídas ao crescimento expressivo do uso do automóvel, associado a um sistema deficiente de transporte coletivo e de massa e a impactos negativos provocados pela circulação de cargas em áreas centrais da 
cidade. Os congestionamentos geram prejuízos anuais de $\mathrm{R} \$ 350$ milhões (US\$ 200 milhões), somente no município de São Paulo (Cetesb, 2008).

Constatada a gravidade da poluição gerada pelos veículos, a Cetesb, durante a década de 80 , desenvolveu as bases técnicas que culminaram com a Resolução n 18/86 do Conama, que estabeleceu o Programa de Controle da Poluição do Ar por Veículos Automotores - Proconve, posteriormente complementados por outras Resoluções do Conama.

O Proconve foi baseado na experiência internacional dos países desenvolvidos e exige que os veículos e motores novos atendam a limites máximos de emissão, em ensaios padronizados e com combustíveis de referência. O programa impõe ainda a certificação de protótipos, de veículos importados e em produção, a autorização especial do órgão ambiental federal para uso de combustíveis alternativos, o recolhimento e reparo dos veículos ou motores encontrados em desconformidade com a produção ou o projeto, e proíbe a comercialização dos modelos de veículos não homologados segundo seus critérios. Desde 1986 é obrigatório no Brasil o Estudo de Impacto Ambiental para rodovias, ferrovias, portos e terminais de minérios, aeroportos, oleodutos, gasodutos e outros, exigência que vem trazendo resultados na prevenção e controle de impactos ambientais gerados pela infra-estrutura de transportes. Porém, essa legislação é baseada na EPA (padrão norte-americano), o que torna as justificativas técnicas não adequadas às condições tropicais brasileiras.

A Cetesb é o órgão técnico conveniado do Ibama para assuntos de homologação de veículos, tendo a responsabilidade pela implantação e operacionalização do Proconve no país. Assim, todos os novos modelos de veículos e motores nacionais e importados são submetidos obrigatoriamente à homologação quanto à emissão de poluentes. Para tal, são analisados os parâmetros de engenharia do motor e do veículo relevantes à emissão de poluentes, sendo também submetidos a rígidos ensaios de laboratório, onde as emissões reais são quantificadas e comparadas aos limites máximos em vigor. A Lei Federal $n^{0} 8.723$ de 28 de outubro de 1993 (republicada no Diário Oficial da União por incorreções em 29 de outubro de 1993) definiu os limites de emissão para veículos leves e pesados, apresentados na tabela 2.6.5.1. 
Tabela 2.6.5.1 - Limites máximos de emissão para veículos leves novos

\begin{tabular}{|c|c|c|c|c|c|c|c|}
\hline Ano & $\begin{array}{c}\mathrm{CO} \\
(\mathrm{g} / \mathrm{km})\end{array}$ & $\begin{array}{c}\mathrm{HC} \\
(\mathrm{g} / \mathrm{km})\end{array}$ & $\begin{array}{c}\mathrm{NO}_{\mathrm{x}} \\
(\mathrm{g} / \mathrm{km})\end{array}$ & $\begin{array}{c}\mathrm{RCHO}^{2} \\
(\mathrm{~g} / \mathrm{km})\end{array}$ & $\begin{array}{c}\mathrm{MP}^{3} \\
(\mathrm{~g} / \mathrm{km})\end{array}$ & $\begin{array}{c}\text { EVAP. } \\
(\mathrm{g} / \mathrm{teste})\end{array}$ & $\begin{array}{c}\text { CO-ML } \\
(\% \text { ol) }\end{array}$ \\
\hline $89-91$ & 24 & 2,1 & 2,0 & - & - & 6 & 3 \\
\hline $92-96$ & 24 & 2,1 & 2,0 & 0,15 & - & 6 & 3 \\
\hline M2-93 & 12 & 1,2 & 1,4 & 0,15 & - & 6 & 2,5 \\
\hline Março 94 & 12 & 1,2 & 1,4 & 0,15 & 0,05 & 6 & 2,5 \\
\hline Janeiro 97 & 2,0 & 0,3 & 0,6 & 0,03 & 0,05 & 6 & 0,5 \\
\hline Maio 03 & 2,0 & 0,3 & 0,6 & 0,03 & 0,05 & 2 & 0,5 \\
\hline Jan/05 (40\%) & 2,0 & $0,16^{5}$ & $0,25^{7}$ & 0,03 & 0,05 & 2 & $0,5^{7}$ \\
\hline Jan/06 (70\%) & 2,0 & Ou & Ou & 0,03 & 0,05 & 2 & $0,5^{7}$ \\
\hline Jan/07 (100\%) & 2,0 & $0,30^{6}$ & $0,60^{3}$ & 0,03 & 0,05 & 2 & $0,5^{7}$ \\
\hline Jan/09 & 2,0 & $0,05^{5}$ ou & $0,12^{7}$ ou & 0,02 & 0,05 & 2 & $0,5^{7}$ \\
\hline Jan/09 & 2,0 & $0,30^{6}$ & $0,25^{3}$ & 0,02 & 0,05 & 2 & $0,5^{7}$ \\
\hline
\end{tabular}

1- Medição de acordo com a NBR6601 (US-FTP75), e conforme as Resoluções Conama $n^{\circ} 15 / 95$ e $n^{\circ} 315 / 02$.

2- Apenas para veículos do ciclo Otto. Aldeídos totais de acordo com a NBR 12026.

3- Apenas para veículos do ciclo diesel.

4- Apenas para veículos do ciclo Otto, exceto a GNV.

5- Hidrocarbonetos não metano (NMHC)

6- Hidrocarbonetos totais somente para veículos a GNV, que também atendem o item (5)

7- Apenas para veículos do ciclo Otto, inclusive a GNV.

Fonte - Cetesb (2008)

Os fabricantes de veículos vêm cumprindo as exigências legais, o que resultou na obtenção de redução média de mais de $94 \%$ na emissão de poluentes dos veículos leves novos de 2004, em relação ao início do programa. Os veículos leves foram considerados prioritários pelo Proconve, devido a sua grande quantidade e intensa utilização, que os caracterizaram como o maior problema a ser enfrentado.

O Proconve considera a qualidade do combustível e a concepção tecnológica do motor como os principais fatores da emissão dos poluentes. Para se obter a menor emissão possível, é necessário dispor de tecnologias avançadas de combustão e de dispositivos de controle de emissões, bem como de combustíveis 75 "limpos" (baixo potencial poluidor). O Brasil, pelo fato de ter adicionado $22 \%$ de álcool à gasolina (gasolina $C$ ou gasool), passou a produzir um combustível de elevada qualidade sob o ponto de vista ambiental, o que coloca o país como pioneiro na utilização em larga escala da adição de compostos oxigenados à gasolina e do uso de combustíveis renováveis. Além disso, a compatibilidade entre o motor e o combustível é fundamental para o pleno 
aproveitamento dos benefícios que podem ser obtidos, tanto para a redução das emissões, quanto para a melhoria do desempenho, dirigibilidade, consumo de combustível e manutenção mecânica. Ainda a disponibilidade do etanol hidratado e da mistura gasolina C, no mercado nacional desde o princípio da década de 80 , trouxe benefícios para o meio ambiente e para a saúde pública, destacando-se a redução drástica das concentrações de chumbo na atmosfera, visto que o etanol é também um antidetonante substituto do aditivo à base de chumbo, totalmente retirado do combustível nacional desde 1991. Além disso, a adição de etanol à gasolina trouxe imediatamente reduções da ordem de $50 \%$ na emissão de CO da frota antiga dos veículos.

Esses dados podem ser verificados na Tabela 2.6.5.2, que apresenta os fatores médios de emissão para veículos leves novos. 
Tabela 2.6.5.2 - Fatores médios de emissão para veículos leves novos

\begin{tabular}{|c|c|c|c|c|c|c|c|c|}
\hline $\begin{array}{c}\text { Ano } \\
\text { Modelo }\end{array}$ & $\begin{array}{l}\text { Combus- } \\
\text { Tível }\end{array}$ & $\begin{array}{c}\mathrm{CO} \\
(\mathrm{g} / \mathrm{km})\end{array}$ & $\begin{array}{c}\mathrm{HC} \\
(\mathrm{g} / \mathrm{km})\end{array}$ & $\begin{array}{c}\mathrm{NO}_{\mathrm{x}} \\
(\mathrm{g} / \mathrm{km})\end{array}$ & $\begin{array}{l}\mathrm{RCHO} \\
(\mathrm{g} / \mathrm{km})\end{array}$ & $\begin{array}{c}\mathrm{CO}_{2} \\
(\mathrm{~g} / \mathrm{km})\end{array}$ & $\begin{array}{c}\text { Autonom } \\
\text { ia } \\
(\mathrm{km} / \mathrm{L}) \\
\end{array}$ & $\begin{array}{c}\text { Emissão } \\
\text { evaporativa de } \\
\text { combustivel } \\
\text { (g/teste) } \\
\end{array}$ \\
\hline Pré-1980 & 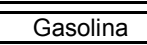 & $\overline{\overline{54,0}}$ & 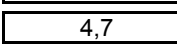 & $\overline{\overline{1,2}}$ & $\overline{0,05}$ & $\overline{\text { nnd }}$ & $\overline{\text { nnd }}$ & $\overline{\text { nd }}$ \\
\hline \multirow[t]{2}{*}{ 1980-1983 } & $\overline{\overline{\text { Gasolina C }}}$ & $\overline{\overline{33,0}}$ & $\overline{\overline{3,0}}$ & $\overline{1,4}$ & 0,05 & $\overline{\text { nd }}$ & $\overline{\text { nd }}$ & $\overline{\text { nd }}$ \\
\hline & Álcool & $\overline{18,0}$ & $\overline{11,6}$ & $\overline{1,0}$ & 0,16 & $\begin{array}{c}\text { nd } \\
\end{array}$ & $\overline{\text { nd }}$ & $\overline{n d}$ \\
\hline \multirow[t]{2}{*}{ 1984-1985 } & 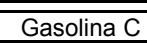 & $\overline{28,0}$ & $\overline{2,4}$ & $\overline{11,6}$ & 0,05 & $\begin{array}{c}\text { nd } \\
\end{array}$ & $\overline{\text { nd }}$ & 23 \\
\hline & Álcool & 16,9 & 1,6 & $\overline{1,2}$ & 0,18 & nd & nd & $\overline{10}$ \\
\hline \multirow[t]{2}{*}{ 1986-1987 } & $\begin{array}{l}\text { Gasolina C } \\
\end{array}$ & 22,0 & 2,0 & $\overline{1,9}$ & 0,04 & nd & nd & 23 \\
\hline & Álcool & 16,0 & $\overline{11,6}$ & $\overline{1,8}$ & 0,11 & nd & nnd & $\overline{10}$ \\
\hline \multirow[t]{2}{*}{1988} & Gasolina C & $\overline{18,5}$ & 1,7 & $\overline{1,8}$ & 0,04 & $\overline{\mathrm{nnd}}$ & $\overline{\mathrm{nd}}$ & 23 \\
\hline & Álcool & 13,3 & $\overline{11,7}$ & $\overline{1,4}$ & 0,11 & $\overline{\mathrm{nnd}}$ & $\overline{\mathrm{nd}}$ & $\overline{10}$ \\
\hline \multirow[t]{2}{*}{1989} & $\begin{array}{l}\text { Gasolina C } \\
\end{array}$ & $\overline{~ 15,2(-46 \%)}$ & \begin{tabular}{c|}
$1,6(-33 \%)$ \\
\end{tabular} & $1,6(0 \%)$ & $0,040(-20 \%)$ & हnd & nd & $23,0(0 \%)$ \\
\hline & Álcool & $12,8(-24 \%)$ & $1,6(0 \%)$ & $1,1(-8 \%)$ & $0,110(-39 \%)$ & nd & nd & $10,0(0 \%)$ \\
\hline \multirow[t]{2}{*}{1990} & Easolina C & 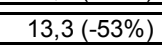 & 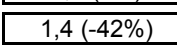 & $\overline{~ 1,4(-13)}$ & $0,040(-20 \%)$ & $\overline{\mathrm{nd}}$ & $\overline{\text { nd }}$ & $2,7(-88 \%)$ \\
\hline & $\overline{\text { Álcool }}$ & 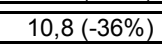 & 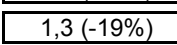 & $1,2(-0 \%)$ & $0,110(-39 \%)$ & $\overline{\mathrm{nd}}$ & $\overline{\text { nnd }}$ & 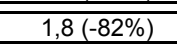 \\
\hline \multirow{2}{*}{ 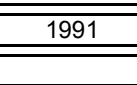 } & \begin{tabular}{|l} 
Gasolina C \\
\end{tabular} & $11,5(-59 \%)$ & $1,3(-46 \%)$ & $1,3(-19 \%)$ & $0,040(-20 \%)$ & nd & nd & $2,7(-88 \%)$ \\
\hline & Álcool & $8,4(-50 \%)$ & 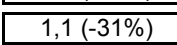 & $1,0(-17 \%)$ & $0,110(-39 \%)$ & nd & nd & $1,8(-82 \%)$ \\
\hline \multirow[t]{2}{*}{1992} & $\begin{array}{l}\text { Gasolina C } \\
\end{array}$ & 6,2(-78\%) & $0,6(-75 \%)$ & 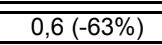 & $0,013(-74 \%)$ & "nd & "nd & $2,0(-91 \%)$ \\
\hline & Álcool & $3,6(-79 \%)$ & $\begin{array}{l}0,6(-63 \%) \\
\end{array}$ & $0, \overline{0,5(-58 \%)}$ & $0,035(-81 \%)$ & "nd & "nd & \begin{tabular}{c|}
$0,9(-91 \%)$ \\
\end{tabular} \\
\hline \multirow[t]{2}{*}{$\overline{1993}$} & $\begin{array}{l}\text { Gasolina C } \\
\end{array}$ & 6 & $\begin{array}{l}0,6(-75 \%) \\
\end{array}$ & $0,8(-50 \%)$ & $0,022(-56 \%)$ & $\begin{array}{l}\text { nd } \\
\end{array}$ & "nd & \begin{tabular}{c|}
$1,7(-93 \%)$ \\
\end{tabular} \\
\hline & $\overline{~ A ́ l c o o l ~}$ & $4,2(-75 \%)$ & $\begin{array}{l}0,7(-56 \%) \\
\end{array}$ & $\overline{0,6(-50 \%)}$ & $0,040(-78 \%)$ & $\overline{\text { nd }}$ & $\overline{\text { nd }}$ & $1,1(-89 \%)$ \\
\hline \multirow[t]{2}{*}{1994} & 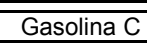 & 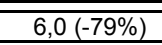 & 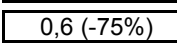 & $0,7(-56 \%)$ & $0,036(-28 \%)$ & $\overline{\text { nd }}$ & $\overline{\text { nd }}$ & \begin{tabular}{c|}
$1,6(-93 \%)$ \\
\end{tabular} \\
\hline & Álcool & $4,6(-73 \%)$ & 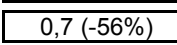 & $0,7(-42 \%)$ & $0,042(-77 \%)$ & $\begin{array}{c}\text { nd } \\
\end{array}$ & $\overline{\text { nd }}$ & $\overline{\overline{0,9(-91 \%)}}$ \\
\hline \multirow[t]{2}{*}{1995} & $\begin{array}{l}\text { Gasolina C } \\
\end{array}$ & $4,7(-83 \%)$ & $0,6(-75 \%)$ & $0,0(-62 \%)$ & $0,025(-50 \%)$ & nd & nd & \begin{tabular}{c|}
$1,6(-93 \%)$ \\
\end{tabular} \\
\hline & Álcool & $4,6(-73 \%)$ & \begin{tabular}{c|}
$0,7(-56 \%)$ \\
\end{tabular} & $0,7(-42 \%)$ & $0,042(-77 \%)$ & nnd & nnd & 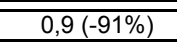 \\
\hline \multirow[t]{2}{*}{1996} & $\begin{array}{l}\text { Gasolina C } \\
\end{array}$ & $3,8(-86 \%)$ & $0,0,4(-83 \%)$ & $0,5(-69 \%)$ & $0,019(-62 \%)$ & nnd & nnd & \begin{tabular}{c|}
$1,2(-95 \%)$ \\
\end{tabular} \\
\hline & Álcool & $3,9(-77 \%)$ & $0,6(-63 \%)$ & $0,7(-42 \%)$ & $\overline{0,040(-78 \%)}$ & nd & nd & $0,8(-92 \%)$ \\
\hline \multirow[t]{2}{*}{1997} & \begin{tabular}{|l|l} 
Gasolina C \\
\end{tabular} & $1,2(-96 \%)$ & $\begin{array}{c}0,2(-92 \%) \\
\end{array}$ & $0,3(-81 \%)$ & $0,007(-86 \%)$ & nd & nd & $\begin{array}{l}1,0(-96 \%) \\
\end{array}$ \\
\hline & Álcool & $0,9(-95 \%)$ & 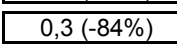 & $0,3(-75 \%)$ & $0,012(-93 \%)$ & "nd & nd & $1,1,(-82 \%)$ \\
\hline \multirow[t]{2}{*}{1998} & $\begin{array}{l}\text { Gasolina C } \\
\end{array}$ & $0,79(-97 \%)$ & 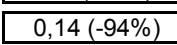 & 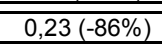 & $0,004(-92 \%)$ & "nd & nd & $\overline{0,81(-96 \%)}$ \\
\hline & Álcool & $0,67(-96 \%)$ & $0,19(-88 \%)$ & $0,24(-80 \%)$ & $0,014(-92 \%)$ & nd & $\overline{n d}$ & $1,33(-87 \%)$ \\
\hline \multirow[t]{2}{*}{1999} & $\begin{array}{l}\text { Gasolina C } \\
\end{array}$ & $0,74(-97 \%)$ & $0,14(-94 \%)$ & $0,23(-86 \%)$ & $0,004(-92 \%)$ & $\begin{array}{l}\text { nd } \\
\end{array}$ & $\begin{array}{l}\text { nd } \\
\end{array}$ & $\overline{0,79(-96 \%)}$ \\
\hline & Álcool & $=0,60(-96 \%)$ & 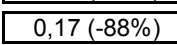 & 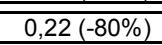 & 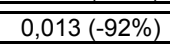 & $\overline{\text { nnd }}$ & $\overline{\text { nnd }}$ & $\overline{11,64(-84 \%)}$ \\
\hline \multirow[t]{2}{*}{2000} & 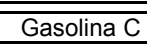 & $0,73(-97 \%)$ & 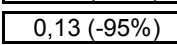 & 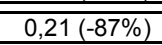 & $0,004(-92 \%)$ & $\overline{\text { nnd }}$ & $\overline{\text { nnd }}$ & $\begin{array}{c}0,73(-97 \%) \\
\end{array}$ \\
\hline & Álcool & 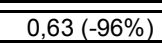 & 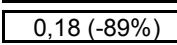 & $\overline{0,21(-83 \%)}$ & $0,014(-92 \%)$ & $\begin{array}{c}\text { nd } \\
\end{array}$ & $\overline{\text { nd }}$ & $\overline{11,35(-87 \%)}$ \\
\hline \multirow[t]{2}{*}{2001} & 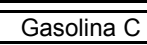 & $0,48(-98 \%)$ & 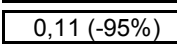 & $0,14(-91 \%)$ & $0,004(-92 \%)$ & $\overline{\text { nnd }}$ & $\overline{\text { nd }}$ & 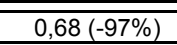 \\
\hline & Álcool & 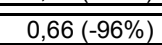 & $0,15(-91 \%)$ & $0,08(-93 \%)$ & $0,017(-91 \%)$ & $\overline{\mathrm{nd}}$ & $\overline{\text { nd }}$ & $\overline{1,31(-87 \%)}$ \\
\hline \multirow[t]{2}{*}{$2002^{(4)}$} & $\begin{array}{l}\text { Gasolina C } \\
\end{array}$ & $0,43(-98 \%)$ & 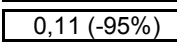 & $0,12(-95 \%)$ & $0,004(-92 \%)$ & 198 & 10,9 & 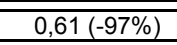 \\
\hline & Álcool & $0,74(-98 \%)$ & $0,16(-90 \%)$ & $0,08(-93 \%)$ & $0,017(-91 \%)$ & 191 & $7 \overline{7,2}$ & $\begin{array}{l}\text { nd } \\
\end{array}$ \\
\hline $2003^{(5)}$ & Gasolina C & 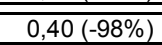 & $0,11(-95 \%)$ & $0,12(-93 \%)$ & $0,004(-92 \%)$ & 194 & $\overline{11,2}$ & $\overline{0,75(-97 \%)}$ \\
\hline & Álcool & $0,77(-95 \%)$ & $\overline{0,16(-90 \%)}$ & 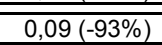 & $0,019(-89 \%)$ & 183 & $\overline{77,5}$ & $\overline{\mathrm{nd}}$ \\
\hline & Flex-Gasol. C & $0,50(-98 \%)$ & $0,05(-98 \%)$ & "0,04 (-98\%) & 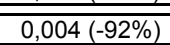 & 2210 & $\overline{10,3}$ & $\overline{\mathrm{nd}}$ \\
\hline & Flex-álccol & 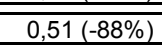 & $0,15(-90 \%)$ & 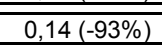 & $0,020(-89 \%)$ & 200 & 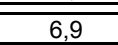 & $\overline{\text { nd }}$ \\
\hline $2004^{(6)}$ & 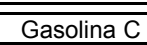 & $0,35(-99 \%)$ & $0,0,11(-95 \%)$ & $0,09(-94 \%)$ & $0,004(-92 \%)$ & 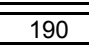 & $\overline{\overline{11,4}}$ & 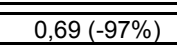 \\
\hline & $\overline{\text { Álcool }}$ & $0,82(-95 \%)$ & $\overline{0,17(-89 \%)}$ & 0,08 (-93\%) & $0,016(-91 \%)$ & 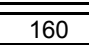 & 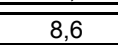 & $\overline{\text { nd }}$ \\
\hline & $\begin{array}{l}\text { Flex-Gasol. C } \\
\end{array}$ & $0,39(-99 \%)$ & $0,08(-97 \%)$ & $0,0,05(-97 \%)$ & $0,003(-94 \%)$ & 201 & 10,8 & $\overline{\mathrm{nd}}$ \\
\hline & 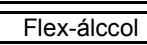 & $0,46(-97 \%)$ & $0,0,14(-91 \%)$ & $0,0,14(-91 \%)$ & $0,014(-92 \%)$ & 190 & $7 \overline{7,3}$ & $\overline{\mathrm{nd}}$ \\
\hline $2005^{(t)}$ & Gasolina C & $0,34(-99 \%)$ & 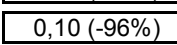 & 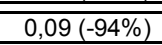 & $0,004(-92 \%)$ & 192 & $\overline{11,3}$ & $\overline{0,90(-96 \%)}$ \\
\hline & Álcool & $0,82(-95 \%)$ & $0,17(-89 \%)$ & 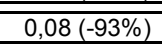 & $0,016(-91 \%)$ & $\begin{array}{l}160 \\
\end{array}$ & 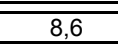 & $\overline{\mathrm{Nd}}$ \\
\hline & $\begin{array}{l}\text { Flex-Gasol. C } \\
\end{array}$ & 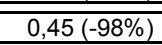 & 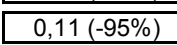 & 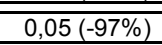 & $0,003(-94 \%)$ & $\begin{array}{l}188 \\
\end{array}$ & $\overline{111,5}$ & $\overline{\mathrm{Nd}}$ \\
\hline & \begin{tabular}{|c|} 
Flex-álccol \\
\end{tabular} & 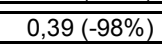 & $\overline{0,14(-91 \%)}$ & 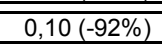 & $0,014(-92 \%)$ & 180 & $\overline{7.7^{(9)}}$ & $\overline{\mathrm{Nd}}$ \\
\hline $2006^{(8)}$ & 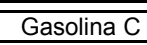 & $0,33(-99 \%)$ & 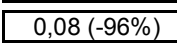 & 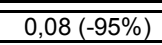 & $0,002(-96 \%)$ & 192 & $\overline{11,3}$ & $\overline{0,46(-98 \%)}$ \\
\hline & Álcool & $0,67(-96 \%)$ & 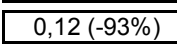 & $\overline{0,05(-96 \%)}$ & $0,014(-92 \%)$ & 200 & 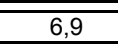 & nd \\
\hline & $\begin{array}{l}\text { Flex-Gasol. C } \\
\end{array}$ & $0,48(-98 \%)$ & 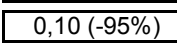 & $\overline{0,05(-97 \%)}$ & $0,003(-94 \%)$ & 185 & $\overline{111,7}$ & 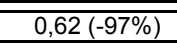 \\
\hline & \begin{tabular}{|l|l|l|l|l|c|} 
Flex-ál \\
\end{tabular} & $0,47(-98 \%)$ & $0,11(-95 \%)$ & $0,07(-96 \%)$ & $0,014(-92 \%)$ & 177 & 7,8 & $1,27(-87 \%)$ \\
\hline
\end{tabular}


1 - Médias ponderadas de cada ano-modelo pelo seu volume da produção.

2 - Com a inclusão do dióxido de carbono, à partir de 2002.

3 - Obtida por balanço de carbono, conforme a NBR 7024, para o ciclo de condução urbana.

4 - Para os modelos a gasolina predominam motores de 1.0L; para os a álcool, de 1.5 à $1.9 \mathrm{~L}$.

5 - Para os modelos a gasolina predominam motores de 1.0L; para os a álcool, de 1.0 e 1.8L. Nos veículos tipo flex fuel, predominam motores de 1,6 e 1,8L. Parte da produção destes veículos foi ensaiada com gasolina $\mathrm{C}$ e parte com álcool carburante.

6 - Para os modelos a gasolina há motores entre 1,0L e 2,0L; para os a álcool, de 1,0L. Nos veículos tipo flex fuel, predominam motores de 1,6 e 1,8L. Parte da produção destes veículos foi ensaiada com gasolina $\mathrm{C}$ e parte com álcool carburante. As maiores diferenças devido às cilindradas dos motores são sentidas no $\mathrm{CO}_{2}$.

7 - Para os modelos a gasolina há motores entre 1,0L e 2,0L; para os a álcool, de 1,0L. Para os veículos tipo flex fuel, predominam motores entre 1,o e 1,8L. Parte da produção destes veículos foi ensaiada com gasolina $\mathrm{C}$ e parte com álcool carburante. As maiores diferenças devido às cilindradas dos motores são sentidas no $\mathrm{CO}_{2}$.

8 - Para os modelos a gasolina há motores entre 1,0L e 2,0L; os modelos a álcool foram descontinuiados, os valores são de um único modelo de 1,8L com produção da ordem de 500 unidades. Para os veículos tipo flex fuel há motores entre 1,0L e 2,0L. As maiores diferenças devido à cilindrada dos motores são sentidas no $\mathrm{CO}_{2}$.

9 - No relatório de 2005, consta erroneamente o valor de $8,6 \mathrm{~km} / \mathrm{L}$, sendo o correto de $7,7 \mathrm{~km} / \mathrm{L}$

nd - Não disponível

(\%) - Refere-se à variação verificada em relação aos veículos 1985, antes da atuação do Proconve.

Gasolina C: $78 \%$ gasolina $+22 \%$ álcool anidro $(v / v)$.

Fonte - Cetesb (2008)

A partir desses dados, notem-se principalmente os valores apresentados para os veículos fabricados no ano de 2004 , já que este é o ano do veículo utilizado nos ensaios.

Há uma tendência mundial para a adição de compostos oxigenados à gasolina, visando à redução do impacto poluidor. A experiência internacional nesse sentido tem demonstrado a superioridade da utilização de alcoóis, notadamente do etanol como no caso brasileiro, em relação aos éteres, sob o ponto de vista ambiental e de saúde pública.

O Proconve adota uma abordagem bottom-up. Nessa abordagem a previsão é realizada diretamente para cada item ou para cada localidade e, posteriormente, agregado. Outra abordagem possível é a top-down, também conhecida como abordagem analítica, em que se realizam previsões para séries consolidadas, feitas para grupos ou famílias e depois desagregada para cada item, segundo o percentual histórico. Também é possível fazer uma previsão agregada para uma região e, então, decompor em previsões para as diversas localidades que compõem esta região, segundo sua representatividade histórica. Assim, o Proconve estima o total de emissões a partir de fatores de emissão médios para cada ano-modelo de veículo, nos quais são aplicados fatores de deterioração, multiplicados pela frota de cada ano-modelo em um determinado ano multiplicado 
pela quilometragem percorrida pelos veículos. Assim, podem-se estimar as emissões de origem veicular " $E$ " de um poluente " $p$ " em um ano "t" através da equação 2.6.5.1 abaixo:

Equação 2.6.5.1 - Modelo de estimativa adotado pelo Proconve

$$
E_{p, t}=\sum_{c, i}\left(F_{c, i, t} \times K_{c, i, t} \times\left(F E_{c, i, p} \times F D_{c, i, p}\right)\right)
$$

Onde:

i é a parcela da frota fabricada em cada ano ("ano-modelo");

c é o tipo de combustível empregado (gasool, álcool, GNV);

$E_{p, t}$ são as emissões de origem veicular de um poluente $p$ no ano $t$;

$\mathrm{F}_{\mathrm{c}, \mathrm{i}, \mathrm{t}}$ é o número de veículos ano-modelo i em circulação no ano $t$ usando combustível $\mathrm{c}$;

$\mathrm{K}_{\mathrm{c}, \mathrm{i}, \mathrm{t}}$ é a distância média percorrida em quilômetros;

$\mathrm{FE}_{\mathrm{c}, \mathrm{i}, \mathrm{p}}$ é o fator médio de emissão dos veículos novos;

$\mathrm{FD}_{\mathrm{c}, \mathrm{i}, \mathrm{p}}$ é o fator de deterioração das emissões de um veículo.

Para fins de inventários, a Cetesb usa fatores de emissão adaptados da EPA e não os medidos no processo de licenciamento (que são medidos em $\mathrm{g} / \mathrm{kWh}$ ), que podem não refletir corretamente as variações nos "FE" induzidas pelo Proconve. Para os fins que o inventário de emissões da Cetesb serve, tal aproximação é plenamente válida, mas para os propósitos deste trabalho tal simplificação impede a modelagem das emissões. A Resolução Conama $n^{\circ} 7$, de 31.08.93, define as diretrizes básicas e os padrões de emissão para o estabelecimento de programas de inspeção e manutenção de veículos em uso.

Os fatores de emissão para veículos novos são obtidos no Laboratório de Emissão Veicular da Cetesb, seguindo a norma NBR-6601, com metodologia semelhante à vigente nos EUA. Para os demais veículos, é aplicado um fator de correção chamado Fator de Degradação (FD), que é obtido segundo o procedimento definido pela norma NBR-6601. A média geral da quilometragem rodada, em geral, é adotada segundo a norma americana US-EPA e também através de pesquisa junto a motoristas brasileiros em relação à quilometragem acumulada no odômetro em um ano. A tabela 2.6.5.3 resume os dados relativos à média de quilometragem percorrida no ano, adotado pela Cetesb para cálculos de inventários. 
Tabela 2.6.5.3 - Média geral da quilometragem anual percorrida pelos veículos

\begin{tabular}{|c|c|}
\hline \multicolumn{2}{|c|}{ Tipo de veículo km/ano } \\
\hline Gasolina & 12.000 \\
\hline Álcool & 18.300 \\
\hline Diesel & 80.000 \\
\hline Táxi & 60.000 \\
\hline Motocicletas e similares & 12.000 \\
\hline \multicolumn{2}{|c|}{ Fonte - Cetesb (2008) } \\
\hline
\end{tabular}

Os dados referentes à evolução da frota de veículos automotores são extraídos do relatório do Ministério dos Transportes e do Departamento Nacional de Trânsito - Denatran (2008). Os resultados desses cálculos são apresentados nos relatórios anuais de emissões da Cetesb, em toneladas de poluentes/ano, ou seja, os dados referentes às emissões são calculados em termos de unidade de massa por unidade de tempo. Para se obter a razão de emissão por região de estudo, é necessário também se dividir essas emissões por unidade de área, composta em geral, por quadrados de $25 \mathrm{~km}^{2}$. As emissões de cada um dos poluentes (CO, NOx, HC, PTS etc.) são expressas em termos de gramas/hora para cada hora do dia, para cada quadrado da grade (LANDMANN, 2005).

Como o inventário da Cetesb para as emissões veiculares é apresentado de forma agregada em função da frota total e da quilometragem média rodada por ano, não há como se chegar, através dele, às diferenças nas emissões para cada um dos "quadrados-áreas" da grade. O melhor refinamento possível dos dados é obtido dividindo-se o total emitido pela frota de veículos registrada em cada uma das regiões que a compõem. Mas a entrada de dados, segundo esse método, fica muito agregada, pois não representa as diferenciações intra-urbanas, e também pressupõe que a frota registrada em um município circula somente dentro do seu próprio território, o que não acontece na prática.

Para se calcular a emissão de poluentes dos veículos automotores considerando-se as diferenças intra-urbanas nos modelos usuais, é preciso, antes de tudo, saber a quantidade de veículos que circula em cada uma das vias da malha viária. Esse valor se obtém ou através de contagens de tráfego ou através de simulação. Fazer contagens de tráfego nas vias principais é um trabalho 
muito caro, por isso, o melhor método é obter os dados das quantidades de veículos através de simulação.

Em cidades pequenas e médias, num único quadrado básico pode-se ter representada a grande maioria das rotas da cidade, portanto, essa área pode representar toda a região no que diz respeito à emissão de poluentes.

A localização mais ou menos precisa da emissão dos poluentes tem grande importância quando se estuda, por exemplo, a saúde pública e qualidade de vida na região. Quando se trata de inventários, o estudo pode ser menos preciso na localização exata dos emissores, já que o importante é o total das emissões de uma região. Fatores, como perfil da trajetória, são mais importantes do que onde elas ocorrem plani-metricamente.

Segundo Mendes (2004) os efeitos do Proconve podem ser menores do que os publicados em estudos anteriores, o que indica a necessidade de se criarem novos instrumentos de política para reduzir as emissões veiculares.

Os motores com ignição por centelha possuem dispositivos destinados a reduzir a poluição ambiental produzida pelas emissões de combustão de combustível. Entre esses dispositivos citam-se os potes catalíticos, cuja função é reduzir as emissões transformando $\mathrm{CO}, \mathrm{NO}_{\mathrm{x}}$ e combustível não queimado em $\mathrm{CO}_{2}$, $\mathrm{H}_{2} \mathrm{O}$ e $\mathrm{N}_{2}$.

Para se obter alta eficiência de conversão, isto é transformação do gás poluente em outro não poluente, é necessário que a composição da corrente que passa através do conversor catalítico seja mantida sem grandes oscilações e em condições muito próximas da estequiométrica. Os dispositivos catalíticos utilizados são constituídos por um suporte e um elemento ativo de alumina, para catalisadores esféricos, ou de cerâmica, para catalisadores monolíticos. A fase ativa é constituída por metais preciosos - paládio, platina ou ródio - que são impregnados nas paredes do suporte, em quantidades bem reduzidas. Entre esses metais, o ródio é o mais caro, contudo, é essencial para a redução do $\mathrm{NO}_{\mathrm{x}}$ e não interferindo na oxidação do CO (FARAH, 2004; TURNS, 2000).

As reações catalíticas ocorrem a temperaturas da ordem de 200 a $250^{\circ} \mathrm{C}$, que são atingidas após a partida do motor. A eficiência dessas reações é da ordem de 90\% podendo atingir 99\% (FARAH, 2004). Segundo Silva Filho (2006), os catalisadores passam a funcionar efetivamente apenas em temperatura acima de $350^{\circ} \mathrm{C}$, demandando tempo para ser atingido. Os catalisadores conservam 
sua atividade em condições normais de operação por cerca $80.000 \mathrm{~km}$. Seu envelhecimento se dá por ordem térmica. Entretanto, se o catalisador alcançar temperaturas da ordem de $1000^{\circ} \mathrm{C}$, que podem ser atingidas caso haja grande quantidade de hidrocarboneto não queimado (uma vela de ignição ou sua remoção por alguns minutos, por exemplo) ou por envenenamento, perderá sua função de oxidar os gases tóxicos. Os principais venenos do catalisador é o chumbo que inibe a ação catalítica por entupimento dos poros e o enxofre que inibe a ação catalítica do paládio e pode levar a formação de $\mathrm{H}_{2} \mathrm{~S}$ (FARAH, 2004). Seu custo de reposição é elevado, além de aumentar a pressão de exaustão dos gases queimados, provocando um aumento no consumo de combustível, e consequentemente aumentando as emissões de poluentes.

Também existe a sonda lambda, um equipamento que permite a regulagem da relação ar/combustível em uma região muito próxima da estequiométrica. Esta regulagem necessita de um dispositivo de injeção eletrônico e é efetuada a partir de uma sonda a oxigênio colocada no circuito de descarga, que envia a medida do teor de oxigênio no gás de combustão ao sistema de injeção eletrônica, o qual dosa a quantidade de gasolina para a condição estequiométrica.

Nas cidades de renda média mais alta, como a de São Paulo, o automóvel particular atende grande parte das viagens motorizadas. A queda na inflação, desde 1995, determinou novo ciclo de crescimento da indústria automobilística. A classe média sentiu-se segura para adquirir veículos novos, inclusive importados, pelo fim das barreiras à importação de veículos, peças e componentes. Assim, a frota estadual de automóveis representava em 1997 cerca de $50 \%$ da frota brasileira, respondendo por cerca de $47 \%$ dos deslocamentos urbanos na RMSP. Esse aumento na frota de automóveis provocou uma sensível queda no uso de transporte público no município de São Paulo.

O inverno de 2004, na cidade de São Paulo, mostrou registros recordes de má qualidade do ar, sendo o $\mathrm{O}_{3}$ o responsável pela maioria deles. $\mathrm{O}_{3}$ resulta da reação entre o óxido de nitrogênio e o dióxido de nitrogênio $\left(\mathrm{NO}\right.$ e $\left.\mathrm{NO}_{2}\right)$. Esse processo de formação é desencadeado pela energia solar, sendo que temperaturas acima de $25^{\circ} \mathrm{C}$ e umidade abaixo de $43 \%$ ajudam o processo. Ele tem sido relacionado a um maior número de casos de câncer.

Estima-se que em 2020 haverá aumento de 93\% da demanda por transportes de bens, com 1,3 bilhões de toneladas anuais no Estado. Outra 
questão fundamental nas políticas para o setor de transportes é a emissão de poluentes, intensificada pelo predomínio do transporte individual frente ao coletivo, e pelo uso prioritário do diesel e da gasolina em detrimento dos combustíveis alternativos.

De forma ampla, a qualidade do ar da região metropolitana apresenta os dados apresentados nas tabelas 2.6.5.4 e 2.6.5.5:

Tabela 2.6.5.4 - Padrões de qualidade do ar - material particulado

\begin{tabular}{|c|c|c|}
\hline \multicolumn{3}{|c|}{ Padrões de qualidade do ar - material particulado } \\
\hline Partículas Totais em Suspensão (PTS) & 24 Horas & Anual \\
\hline Fumaça (FMC) & $240 \mu \mathrm{g} / \mathrm{m}^{3}$ & $80 \mu \mathrm{g} / \mathrm{m}^{3}$ \\
\hline Partículas Inaláveis (MP) & $150 \mu \mathrm{g} / \mathrm{m}^{3}$ & $60 \mu \mathrm{g} / \mathrm{m}^{3}$ \\
\hline Partículas Inaláveis Finas (MP) & $150 \mu \mathrm{g} / \mathrm{m}^{3}$ & $50 \mu \mathrm{g} / \mathrm{m}^{3}$ \\
\hline Fonte - Cetesb (2008) & - & $15 \mu \mathrm{g} / \mathrm{m}^{3}$ \\
\hline
\end{tabular}

Tabela 2.6.5.5 - Padrões de qualidade do ar - gases

\begin{tabular}{|c|c|}
\hline $\begin{array}{l}\text { Dióxido de } \\
\text { enxofre } \\
\left(\mathrm{SO}_{2}\right)\end{array}$ & $\begin{array}{l}\text { As concentrações sofreram uma redução sensível ao longo dos anos e hoje } \\
\text { todas as estações atendem aos padrões primários e secundários de qualidade } \\
\text { do ar. Ressalte-se ainda que mesmo o novo limite sugerido pela Organização } \\
\text { Mundial da Saúde - OMS - }\left(125 \mu \mathrm{g} / \mathrm{m}^{3}-24 \mathrm{~h}\right) \text { está sendo respeitado em todos } \\
\text { os locais monitorados na RMSP. }\end{array}$ \\
\hline $\begin{array}{l}\text { Monóxido de } \\
\text { carbono (CO) }\end{array}$ & $\begin{array}{l}\text { As concentrações de monóxido de carbono excedem o padrão de qualidade do } \\
\text { ar para } 8 \text { horas (9ppm), em alguns dias de inverno. Não têm sido observadas } \\
\text { ultrapassagens do nível de atenção (15ppm). As concentrações médias } \\
\text { apresentam tendência de queda, motivados principalmente pela renovação da } \\
\text { frota de veículos leves. }\end{array}$ \\
\hline Ozônio $\left(\mathrm{O}_{3}\right)$ & 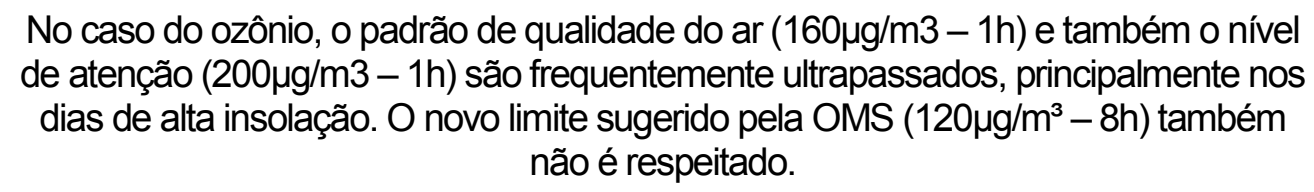 \\
\hline $\begin{array}{l}\text { Dióxido de } \\
\text { nitrogênio } \\
\quad\left(\mathrm{NO}_{2}\right)\end{array}$ & 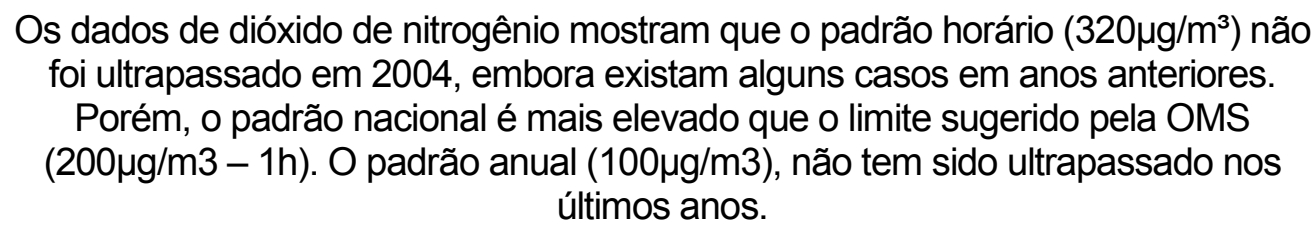 \\
\hline
\end{tabular}

Fonte - Cetesb (2008) 
Segundo Onursal e Gautan (1997), desenhar uma estratégia de abatimento da poluição atmosférica veicular em áreas urbanas requer um bom entendimento da natureza e magnitude do problema de poluição do ar e aplicabilidade de diversas medidas de abatimento. A política das medidas de abatimento pode ser classificada como de Comando e Controle ou Incentivos baseados no Mercado. A escolha do tipo de medida depende dos custos e benefícios, bem como da capacidade de monitoramento e imposição das instituições responsáveis.

Segundo Onursal e Gautan (1997) e Maclean e Lave (2003) as medidas de Comando e Controle para reduzir a poluição do ar contam principalmente com opções regulatórias. Essas medidas incluem:

- Padrões de emissão que fixam uma quantidade ou concentração máxima de poluentes que legalmente podem ser emitidos pelos veículos

- Padrões de especificação da qualidade do combustível para os veículos

- Padrões de economia de combustíveis

- Critérios para teste e regulamentação para os novos veículos

- Exigências de inspeção e manutenção para os veículos em uso

- Restrições de tráfego

Desde quando a poluição foi vista como uma externalidade negativa, os custos não são completamente assumidos pelos poluidores. Incentivos de mercado, baseados no princípio do "poluidor pagador", impõem um custo sobre as atividades poluidoras, dessa forma internalizando um valor para externalidade. Alguns poluidores preferem pagar o "preço" imposto pelo órgão regulador do que diminuir os níveis de poluição, enquanto outros acham mais barato modificar suas atividades atuais de forma a reduzir ou eliminar a poluição. Incentivos baseados no Mercado têm sido usados para controlar a poluição veicular incluindo taxas sobre os veículos, taxas sobre os combustíveis etc. (ONURSAL; GAUTAN, 1997).

A tabela 2.6.5.6 apresenta algumas medidas que poderiam ser adotadas. 
Tabela 2.6.5.6 - Medidas para amenizar a poluição veicular

\begin{tabular}{|c|c|c|c|}
\hline Tipo de Medida & Comando e Controle & \multicolumn{2}{|c|}{ Incentivos Baseados no Mercado } \\
\hline \multirow{10}{*}{$\begin{array}{l}\text { O Alvo é o } \\
\text { Veículo }\end{array}$} & $\begin{array}{l}\text { Padrões de emissões e medidas } \\
\text { relacionadas a novos veículos }\end{array}$ & \multicolumn{2}{|c|}{ Taxa sobre as emissões veiculares } \\
\hline & Padrões de emissões & \multicolumn{2}{|c|}{$\begin{array}{l}\text { Taxas e impostos diferenciados nos } \\
\text { registros de veículos }\end{array}$} \\
\hline & Certificações & \multicolumn{2}{|c|}{ Programas de Ajustes (Retrofit) } \\
\hline & Testes nas linhas de produção & \multicolumn{2}{|c|}{$\begin{array}{c}\text { Incentivos ao sucateamento ou troca dos } \\
\text { veículos antigos }\end{array}$} \\
\hline & $\begin{array}{l}\text { Programas de chamada de } \\
\text { retorno aos fabricantes em caso } \\
\text { de não enquadramento aos } \\
\text { padrões de emissão (Recall) }\end{array}$ & & \\
\hline & Garantias & & \\
\hline & $\begin{array}{c}\text { Padrões de emissão e programas } \\
\text { de inspeção para veículos em } \\
\text { uso }\end{array}$ & & \\
\hline & $\begin{array}{l}\text { Programas de Inspeção e } \\
\text { Manutenção (I/M) }\end{array}$ & & \\
\hline & $\begin{array}{l}\text { Programas de inspeção à } \\
\text { margem da estrada }\end{array}$ & & \\
\hline & $\begin{array}{l}\text { Restrições de emissão para os } \\
\text { veículos importados }\end{array}$ & & \\
\hline \multirow{6}{*}{$\begin{array}{l}\text { Alvo é o } \\
\text { combustível }\end{array}$} & Padrões para Gasolina & \multicolumn{2}{|c|}{ Taxas sobre os combustíveis } \\
\hline & Chumbo & \multicolumn{2}{|c|}{ Comércio de créditos e permissões } \\
\hline & Volatilidade & & \\
\hline & Benzeno e outros aromáticos & & \\
\hline & Reformulação & & \\
\hline & Oxigenados & & \\
\hline \multirow{7}{*}{$\begin{array}{l}\text { Gerenciamento } \\
\text { de } \\
\text { Transportes }\end{array}$} & Leis de direção & Pedágios & Medidas adicionais \\
\hline & $\begin{array}{l}\text { Restrições ao estacionamento e } \\
\text { comércio em ruas }\end{array}$ & \multirow{6}{*}{$\begin{array}{l}\text { Licenciamento } \\
\text { de áreas }\end{array}$} & $\begin{array}{l}\text { Fornecimento de } \\
\text { serviços de } \\
\text { transportes públicos }\end{array}$ \\
\hline & $\begin{array}{l}\text { Medidas de tráfego prioritárias } \\
\text { para ônibus }\end{array}$ & & $\begin{array}{l}\text { Estímulo ao transporte } \\
\text { não motorizado }\end{array}$ \\
\hline & Viagem compartilhada (“carona”) & & \multirow{4}{*}{$\begin{array}{l}\text { Estacionamento fora } \\
\text { das vias de tráfego }\end{array}$} \\
\hline & $\begin{array}{l}\text { Escalonamento dos horários de } \\
\text { trabalho }\end{array}$ & & \\
\hline & $\begin{array}{l}\text { Limites de velocidade e outras } \\
\text { medidas de gerenciamento de } \\
\text { trafego }\end{array}$ & & \\
\hline & $\begin{array}{l}\text { Planos e controles de utilização } \\
\text { do solo }\end{array}$ & & \\
\hline
\end{tabular}

Há, no Brasil, alguns projetos que visam diminuir a poluição gerada por veículos automotores e que estão descritos a seguir. 
O Projeto Economizar, criado em 1996, oferece gratuitamente apoio técnico ao setor de transporte rodoviário - cargas e passageiros -, visando a racionalizar o consumo de óleo diesel e promover a melhoria da qualidade do ar, reduzindo a emissão de fumaça preta de ônibus e caminhões. O Economizar é fruto de uma articulação entre os setores público e privado, estruturada por intermédio de um convênio de cooperação técnica entre a Petrobras, por meio do Programa Nacional de Racionalização do Uso dos Derivados de Petróleo e do Gás Natural (CONPET), o Ministério de Minas e Energia, o Ministério dos Transportes e a Confederação Nacional do Transporte (CNT), por meio do Instituto de Desenvolvimento Assistência Técnica e Qualidade em Transporte (Idaq). O CONPET é um programa do Ministério de Minas Energia, coordenado por representantes de órgãos do governo. Foi instituído por decreto federal em 1991 e seu principal objetivo é incentivar o uso eficiente das fontes de energia nãorenováveis no transporte, nas residências, no comércio, na indústria e na agropecuária.

A organização e o modo de funcionamento do Projeto Economizar compreendem uma coordenação nacional e supervisões regionais. A coordenação nacional - Petrobrás/CONPET e CNT/Idaq - é responsável pela articulação institucional, pelo estabelecimento de metas a serem atingidas, pela aprovação de normas e procedimentos operacionais, além do acompanhamento e avaliação dos resultados. Às supervisões regionais cabem a elaboração das normas e procedimentos operacionais e o planejamento e controle da execução dos trabalhos de campo nas respectivas áreas de influência. O Projeto Economizar é provido de unidades móveis dotadas dos instrumentos necessários para analisar os pontos críticos que influenciam o uso racional do óleo diesel. A parceria deve realizar a avaliação dos seguintes pontos:

- Metodologia de gestão do uso dos combustíveis pelos transportadores;

- Estado dos veículos e rendimento dos motores (teste de fumaça com opacímetro);

- Práticas de manutenção dos veículos;

- Qualificação de motoristas e mecânicos;

- Qualidade do diesel consumido, cuidados com o recebimento, armazenagem e instalações; 
- Identificação de práticas e experiências bem-sucedidas adotadas pelas empresas que contribuem para o aumento da eficiência do uso do óleo diesel.

A Iniciativa de Ar Limpo nas Cidades da América Latina é um programa lançado pelo Banco Mundial, em dezembro de 1998, que procura apoiar essas cidades em ações de melhoria e reunir esforços dos governos locais, dos setores privados, dos órgãos ambientais, da sociedade civil, das organizações nãogovernamentais e de entidades internacionais. As cidades que atualmente participam diretamente da Iniciativa são Rio de Janeiro, São Paulo, Lima, México, Bogotá, Santiago e Buenos Aires, devido a suas condições de poluição atmosférica (PIZZOTTI; XAVIER; LOUREIRO, 2003).

Também, de acordo com as metas do Proconve, os órgãos estaduais de controle ambiental, a partir de 1997, deveriam implantar os Programas de Inspeção e Manutenção de Veículos em Uso, cuja regulamentação se deu através das seguintes resoluções: Resolução Conama 07/93, Resolução Conama 18/95 e Resolução Conama 227/97.

Com o foco especial no Programa de I/M, a Resolução Conama N. 7, de 31.08.93, define as diretrizes básicas e padrões de emissão para o estabelecimento de programas de inspeção e manutenção de veículos em uso.

Entretanto, apenas no Rio de Janeiro foi estabelecido o Programa de I/M, através da Lei Estadual N. 2539, de 19.04.96, restrito à Região Metropolitana na fase inicial e, hoje, abrange todos os municípios (DUBEUX, [2006?]).

O Plano de Controle da Poluição por Veículos em Uso - PCPV - estabelecido no Estado do Rio de Janeiro visa atender às Resoluções Conama $n^{\circ}$ 18/86 e n 7/93, à Resolução n 809 do Contran (Conselho Nacional de Trânsito) e o cumprimento às leis $n^{0} 8.666 / 96$ e 2.539/96. Dessa forma, foi assinado em 30 de janeiro de 1997 o Convênio entre Detran e Feema a fim de cumprir a determinação dos dispositivos legais para o controle de poluentes gasosos, no licenciamento de veículos automotores, na região metropolitana do Rio de Janeiro e, posteriormente, estendido a outros municípios do interior do Estado do Rio de Janeiro. 


\subsection{Inventários de fontes de emissão}

Segundo o Inventário de Fontes Emissoras de Poluentes Atmosféricos da Região Metropolitana do Rio de Janeiro (2004), da Feema, um Inventário de Emissões Atmosféricas é o cálculo da quantidade de certos poluentes atmosféricos emitidos, a partir de dada tipologia de fonte, em um dado intervalo de tempo, para um dado local. $O$ inventário de fontes de emissão de poluição atmosférica constitui um dos instrumentos de planejamento mais úteis para um órgão ambiental, uma vez que qualifica e quantifica as atividades poluidoras do ar e fornece informações sobre as características das fontes, definindo localização, magnitude, frequência, duração e contribuição relativa das emissões. Esse instrumento possibilita a elaboração de diagnósticos que permitirão fortalecer as tomadas de decisão relativas ao licenciamento de atividades poluidoras e as eventuais ações de controle necessárias.

A EPA (1997) define a ferramenta Inventário de Emissões Atmosféricas como uma listagem atualizada e abrangente das emissões atmosféricas causadas por fontes ou grupo de fontes que estão localizadas numa área geográfica específica para um intervalo de tempo definido.

Um inventário de emissões envolve, portanto, a investigação de cada fonte ou grupo de fontes, dentro de uma área para determinar a quantidade e a qualidade dos poluentes de vários tipos que estão sendo lançados na atmosfera.

Usualmente um inventário de emissões deve conter as seguintes informações (EEA, 2003):

- Área geográfica coberta pelo inventário;

- O intervalo de tempo considerado para a estimativa, isto é, anual, mensal, horário, etc.;

- Informações de dados econômicos e/ou sociais, tais como: população, nível de emprego etc., utilizados nas estimativas e distribuição das emissões;

- A descrição das categorias de fontes abrangidas;

- Procedimentos usados para a coleta de dados;

- Fonte dos dados coletados; 
- Cópia dos questionários e resultados (número de questionários enviados, número de respostas recebidas, métodos utilizados para se fazer a extrapolação dos dados não recebidos e, outras considerações realizadas);

- Citação de todos os fatores de emissão utilizados;

- Identificação dos métodos usados para o cálculo das emissões;

- Documentação completa de todas as considerações realizadas;

- Identificação das fontes de emissão não incluídas no inventário;

- Lista de referências.

A preparação do inventário de emissões é um processo contínuo que envolve uma série de etapas inter-relacionadas, como a busca e compilação de dados, vistorias em plantas industriais, envio de questionários e cálculos de emissões, devendo ser executadas com prévio planejamento em vários níveis de aplicação para a obtenção de resultados consistentes e para o bom desempenho das atividades.

Segundo a EEA (2002), o inventário de emissões atmosféricas é a base essencial para todos os programas de gerenciamento da qualidade do ar. Essa ferramenta pode ser usada com vários propósitos, mas frequentemente é desenvolvida para atender às requisições regulamentadas pelas agências ambientais.

Um inventário de emissões pode ser usado para avaliar o status da qualidade do ar de uma região e suas relações com os padrões de qualidade do ar; avaliar a efetividade dos programas de controle de poluição do ar e servir de base para a implementação de mudanças necessárias nesses programas.

As informações técnicas originadas do inventário de emissões podem ainda ter os seguintes usos específicos (EPA, 1997; EEA, 2003):

- Determinar conformidades ou não conformidades com os padrões estabelecidos;

- Estabelecer uma linha de base para medidas de planejamento e controle;

- Identificar as fontes e os níveis de emissões, padrões e tendências para o desenvolvimento de estratégias de controle e novas regulamentações;

- Servir como dados de entrada para o desenvolvimento de modelos preditivos da concentração de poluentes;

- Servir como dados para estudos de avaliação de riscos à saúde humana; 
- Conduzir avaliação de impacto ambiental para fontes novas;

- Servir como base nos processos de licenciamento ambiental;

- Servir como ferramenta nos programas futuros de créditos de emissões;

- Estabelecer áreas para implantação de monitores da qualidade do ar.

A importância dos inventários de emissões aumenta com o avanço na sofisticação dos modelos matemáticos de dispersão e de outras ferramentas utilizadas no gerenciamento da qualidade do ar e, como resultado, o interesse na verificação das emissões se torna difundido.

Um inventário de emissões serve, portanto, para o estabelecimento de sólidas políticas públicas. A formulação de estratégias de controle apropriadas requer uma base de estimativas de emissões de qualidade. Se os dados usados forem falhos ou de origem duvidosa, as políticas públicas derivadas também serão. Os erros daí advindos podem onerar as estratégias de controle, além de prejudicar o bem-estar público e o meio ambiente (EEA, 2004).

Um inventário de emissões é o primeiro passo para a implantação de um sistema de gestão de emissões, sendo um processo de constante evolução e de longo prazo. A execução de um inventário é um esforço que obtém ao longo do tempo resultados cada vez melhores. Metas intermediárias devem ser estipuladas para períodos definidos e as melhorias obtidas anualmente devem ser adequadamente documentadas para que não sejam perdidas.

Inicialmente, esse instrumento de gestão era utilizado, mais comumente, por órgãos ambientais. Atualmente, diversas indústrias dos mais variados segmentos (de petróleo, siderurgia etc.) têm implementado sistemas de inventário de emissões tendo como principais objetivos a otimização de processos, a adequação a atuais e futuros padrões de emissão, o comprometimento com as melhores práticas mundiais e a sustentabilidade dos empreendimentos ao longo do ciclo de vida.

\subsection{Modelos de emissão de poluição}

Segundo Moreira e Tirabassi (2004), a característica teórica dos modelos matemáticos de emissão é essencialmente subdividida em quatro formulações fundamentais. 
- A aproximação K: a difusão é considerada em um ponto fixo no espaço, sendo proporcional ao gradiente local da concentração do material difundido. Consequentemente, tal aproximação é fundamentalmente Euleriana, considerando-se o movimento do fluido relacionado a um sistema de referência fixo no espaço. Tais modelos são os mais adaptados a enfrentar os problemas complexos, como por exemplo, a dispersão de poluentes sobre topografia complexa ou a difusão de poluentes reativos. Eles se baseiam na resolução numérica sobre uma grade espaço-temporal fixa da equação da conservação de massa de uma espécie química poluente.

- Os modelos Eulerianos: constitui a aproximação matemática mais simples porque ignora a estrutura espacial do fenômeno. Ele assume que os poluentes são distribuídos uniformemente no interior de um paralelepípedo (uma caixa). Do ponto de vista teórico, isto equivale a assumir coeficientes de difusão infinitos que provocam uma propagação instantânea do poluente imerso na caixa considerada. O poluente presente na caixa provém da fonte interna, da contribuição externa transportada pelo vento ou flui através do topo em consequência da variação de altura da caixa, que geralmente coincide com a altura da camada limite.

- Os modelos Lagrangeanos: porque utilizam um sistema de referência que segue o movimento da atmosfera. Inicialmente, com o termo Lagrangeano indicava-se somente o modelo de caixa "móvel", que segue a trajetória do vento médio. Atualmente, são imersos nesta classe todos os modelos que acompanham a nuvem de poluentes em "elementos" discretos, como segmento ou partículas fictícias. Nos modelos de partículas, a dispersão de um poluente é simulada através do movimento de partículas fictícias (partículas de computador) cujas trajetórias permitem calcular o campo de concentração da substância imersa, a partir da hipótese básica de que as trajetórias destas partículas simulam o percurso das partículas do ar situado na mesma posição no instante inicial. Os movimentos destas partículas podem ser reproduzidos de modo determinístico e em modo estocástico.

- O modelo Gaussiano: a maior parte dos modelos operacionais para a estimativa da dispersão de gás e partículas na camada limite atmosférica é baseada na aproximação Gaussiana. Ela fundamenta o pressuposto teórico na solução exata, mas não real, da equação de transporte e difusão na 
atmosfera, no caso em que o vento e o coeficiente de difusão turbulenta são constantes com a altura. A solução é forçada a representar situações reais através de parâmetros empíricos, os chamados "sigmas". Podem ser estacionários (independentes do tempo, e considerados "modelos pluma") e os que dependem do tempo. O nome deriva do fato de que a distribuição dos poluentes, ambos vertical e transversalmente à direção do vento, é descrita da famosa curva descoberta pelo físico-matemático Gauss. As várias versões dos modelos Gaussianos se diferenciam essencialmente pela técnica utilizada para calcular o sigma em função da estabilidade atmosférica e da distância da fonte emissora. Podem ser distinguidas duas técnicas fundamentais neste sentido: a primeira faz uso de funções adimensionais construídas com a idéia de medidas disponíveis da intensidade da turbulência; a segunda utiliza funções semi-empíricas para o sigma construído para a classe de estabilidade com que são esquematizados de acordo com o estado da atmosfera.

Os modelos analíticos podem ser considerados intermediários entre o modelo $\mathrm{K}$ e o Gaussiano. Do segundo conservam a simplicidade, pois o campo de concentração é descrito através de uma fórmula simples, mas, ao mesmo tempo, são capazes de considerar, de modo teoricamente mais correto, situações em que o vento e o coeficiente de difusão turbulento variam com a altura.

Segundo Jacondino e Cybis (2003), os fatores de emissão utilizados para cada localidade deveriam ser baseados em medições das taxas de emissão realizadas pelos veículos na área de estudo. A obtenção de medições precisas de fatores de emissão, entretanto, é um processo complexo e de custo elevado. Em razão disso, poucos experimentos são realizados e, além disso, geralmente testam uma pequena quantidade de veículos e sob condições limitadas (em termos das condições de condução dos veículos testados - em laboratório ou em condições reais de tráfego).

Os modelos de emissão de uma maneira geral são utilizados para dois tipos de análise. Eles podem ser utilizados para prever os valores absolutos de poluição (inventários), como, por exemplo, identificar as ruas que excedem os padrões de qualidade do ar. Para este tipo de análise um alto grau de precisão nos fatores de emissão será requerido. Outra finalidade é a sua utilização em avaliações de impacto, como a comparação de diferentes estratégias de tráfego. 
Neste tipo de análise a precisão nos fatores de emissão pode não ser um fator tão importante.

Ainda segundo Jacondino e Cybis (2003), os modelos de emissão podem ser classificados em:

- Modelos baseados na velocidade média: funcionam com base em fatores específicos de emissão para cada tipo e tecnologia de veículo/motor, fator de degradação e uma situação de tráfego médio. Geralmente eles formam a base para o cálculo das emissões de poluentes em escala local, mas também podem ser empregados para inventários regionais ou nacionais;

- Modelos de emissões instantâneos ou modais: leva em conta o modo de operação do veículo através de detalhados parâmetros tais como, aceleração, velocidade e força utilizada pelo motor. Normalmente, são utilizados para a quantificação dos poluentes em escalas locais. A estimativa dos poluentes é feita através do emprego de matrizes de poluentes em função da velocidade $e$ aceleração, ou velocidade e força do motor. Existem ainda os baseados em regressões lineares e paramétricos. Tradicionalmente, são os modelos de emissão associados aos modelos de tráfego;

- Modelos agregados: calculam as emissões médias a partir de estatísticas de uso dos veículos, por exemplo, a quilometragem anual, a divisão dos tipos de vias, etc., incluindo os efeitos das partidas a frio, evaporações, etc e são utilizados para inventários regionais e nacionais de emissões.

Vários programas simuladores de tráfego possuem modelos de emissão e dispersão de gases, como o SIA 3.0 Atmos, Dracula (Dynamic Route Assignment Combining User Learning and Microsimulation), Saturn (Simulation and Assignment of Traffic to Urban Road Networks), EMME/2, EcoGest, , etc. Em geral esses sistemas possuem ferramentas de geoprocessamento, modelos de dispersão, relacionamento com dados de qualidade do ar e meteorologia, e as fontes são inseridas com:

- Localização

- Características físicas (altura, temperatura, altitude)

- Variáveis para a quantificação das emissões e etc.

Esses programas normalmente consideram que a taxa de emissão de certo poluente num determinado período é calculada multiplicando-se o número de veículos pela distância percorrida no trecho da via e pelo fator de 
emissão especifico da frota $(\mathrm{g} / \mathrm{km})$. As taxas de emissão são funções do volume de tráfego de veículos em cada via. Os resultados, na maior parte dos trabalhos, são expressos na forma de taxas de emissão ou em toneladas de poluente por ano (t/ano).

Os dados referentes às emissões são calculados em termos de unidade de massa por unidade de tempo, por unidade de área, para serem inseridos no modelo. Ou seja, a região metropolitana é dividida em uma grade composta por quadrados, por exemplo, de $25 \mathrm{~km}^{2}$ ou com $9 \mathrm{~km}^{2}$ de área, e as emissões de cada um dos poluentes ( $\mathrm{CO}, \mathrm{NO}_{x}, \mathrm{HC}$, PTS etc.) são expressas em termos de gramas/hora para cada hora do dia, para cada quadrado da grade.

A tabela 2.8.1 apresenta a taxa de emissão de poluentes, para veículos leves a gasolina com motor aquecido, utilizada no programa Dracula, onde são aplicadas as taxas de emissão de poluente de acordo com a velocidade dos veículos, operando em condições estabilizadas.

Tabela 2.8.1 - Taxa de emissão para veículos leves á gasolina no programa Dracula

\begin{tabular}{|c|c|c|c|c|c|c|c|c|c|c|}
\hline & \multicolumn{7}{|c|}{ Velocidade $(\mathrm{km} / \mathrm{h})$} & \multicolumn{3}{|c|}{ Modo de operação } \\
\hline $\begin{array}{l}\text { Poluente } \\
(\mathrm{g} / \mathrm{s})\end{array}$ & 10 & 20 & 30 & 40 & 50 & 60 & 70 & Parado & $\begin{array}{l}\text { Acele } \\
\text { rando }\end{array}$ & $\begin{array}{l}\text { Desacele } \\
\text { rando }\end{array}$ \\
\hline $\mathrm{CO}$ & 0,06 & 0,091 & 0,13 & 0,129 & 0,09 & 0,11 & 0,177 & 0,06 & 0,377 & 0,072 \\
\hline $\mathrm{NO}_{x}$ & 0,0006 & 0,0006 & 0,0017 & 0,0022 & 0,0042 & 0,0050 & 0,0058 & 0,0008 & 0,01 & 0,005 \\
\hline $\mathrm{HC}$ & 0,0063 & 0,0078 & 0,0083 & 0,0128 & 0,0097 & 0,0117 & 0,0136 & 0,0067 & 0,02 & 0,0067 \\
\hline
\end{tabular}

A tabela 2.8.2 apresenta a taxa de emissão de poluentes, para veículos leves a gasolina com motor aquecido, utilizada em outros simuladores de tráfego, onde são aplicadas as taxas de emissão de poluente de fixos por veículo no tramo. 
Tabela 2.8.2 - Fatores de emissão sugeridos por Detran e Feema (2001)

\begin{tabular}{|c|c|c|c|c|c|c|}
\hline \multirow{2}{*}{ Fontes de emissão } & Poluente & $\begin{array}{l}\mathrm{CO} \\
\mathrm{g} / \mathrm{km}\end{array}$ & $\begin{array}{c}\mathrm{HC} \\
\mathrm{g} / \mathrm{km}\end{array}$ & $\begin{array}{l}\mathrm{NO}_{\mathrm{x}} \\
\mathrm{g} / \mathrm{km}\end{array}$ & $\begin{array}{l}\mathrm{SO}_{\mathrm{x}} \\
\mathrm{g} / \mathrm{km}\end{array}$ & $\begin{array}{c}\mathrm{MP} \\
\mathrm{g} / \mathrm{km}\end{array}$ \\
\hline & Combustível & & & & & \\
\hline \multirow{3}{*}{ Tubo de escapamento } & Gasolina & 14,00 & 2,40 & 0,85 & 0,20 & 0,08 \\
\hline & Álcool & 18,60 & 2,00 & 1,40 & ----- & ----- \\
\hline & Diesel & 17,80 & 2,90 & 13,00 & 1,13 & 0,81 \\
\hline \multirow{2}{*}{$\begin{array}{c}\text { Emissão do cárter e } \\
\text { evaporativa }\end{array}$} & Gasolina & ------ & 2,10 & ----- & ------ & ----- \\
\hline & Álcool & ------ & 1,60 & & & \\
\hline Pneus & $\begin{array}{c}\text { Todos os } \\
\text { tipos }\end{array}$ & ------ & ------ & ------ & ------ & 0,07 \\
\hline
\end{tabular}

Fonte - Detran e Feema (2001)

Para se chegar aos valores das emissões em gramas/hora, multiplica-se o número total de veículos no tramo pela sua extensão, em quilômetros. E por último, faz-se o somatório das emissões para cada quadrado da grade sobreposta sobre o mapa.

Alguns programas como o EMME/2 faz a alocação dos automóveis na rede viária considerando os melhores trajetos entre as origens e os destinos. O melhor trajeto é considerado aquele de menor tempo de viagem. Como resultado final, o EMME/2 apresenta o número de veículos total em cada tramo. Para fazer estimativas de emissão de poluentes, inserem-se funções matemáticas para os tramos da rede viária, relacionando as emissões com a velocidade média. As funções usadas são as apresentadas no relatório síntese do Instituto de Pesquisa Econômica Aplicada, para a Associação Nacional de Transportes Públicos - ANTP (IPEA; ANTP, 1997).

A equação 2.8.1 apresenta os modelos desenvolvidos pela ANTP que descrevem a estimativa de emissões de poluentes, sendo " $\mathrm{v}$ " $a$ velocidade no tramo em $\mathrm{km} / \mathrm{h}$.

Equação 2.8.1 - Modelo de estimativa de emissões de HC

$$
\mathrm{HC}(\mathrm{g} / \mathrm{km})=-0,28+\frac{62,48}{v}
$$


Equação 2.8.2 - Modelo de estimativa de emissões de CO

$$
\mathrm{CO}(\mathrm{g} / \mathrm{km})=-4,51+\frac{727}{v}+0,00134 * v^{2}
$$

Equação 2.8.3 - Modelo de estimativa de emissões de $\mathrm{NO}_{x}$

$$
\mathrm{NO}_{\mathrm{x}}(\mathrm{g} / \mathrm{km})=1,03+0,007477 * v^{2}
$$

O inventário da Cetesb para as emissões veiculares é apresentado de forma agregada para toda a região metropolitana em função da frota total e da quilometragem média rodada por ano e não há como se chegar, através dele, às diferenças nas emissões para cada um dos "quadrados-áreas" da grade. O melhor refinamento possível dos dados seria obtido dividindo-se o total emitido pela frota de veículos registrada em cada uma das áreas que a compõem. Mas a entrada de dados segundo este método fica muito agregada, pois não representa as diferenciações intra-urbanas, e também pressupõe que a frota registrada em um município circula somente dentro do seu próprio território, o que não acontece na prática. Para calcular as emissões de poluentes dos automóveis considerando-se as diferenças intra-urbanas, seria preciso saber o volume de veículos que circula em cada uma das vias da malha viária. Esse valor pode ser obtido diretamente através de contagens de tráfego, ou através de simulação.

Alguns programas utilizados para planejamento de transportes, os dados inseridos vem através de pesquisa origem/destino e pelas características físicas e operacionais do sistema viário. A pesquisa origem/destino gera uma matriz de viagens segundo o zoneamento de tráfego da região. Ou seja, a região é dividida em zonas de tráfego, e a matriz origem/destino representa o número de viagens entre elas. O sistema viário é representado por tramos e nós. Um tramo representa um trecho de via, e um nó representa um cruzamento de uma ou mais vias. Não necessariamente todos os cruzamentos viários da cidade são representados, pois isto irá depender do grau de detalhamento desejado. Para cada nó são definidas as coordenadas geométricas, e para cada tramo são atribuídos valores referentes às características físicas e operacionais do trecho da via que ele representa. Alguns programas ainda permitem ao usuário associar funções matemáticas a cada tramo. A mais utilizada é função volume/atraso. 


\section{EXPERIMENTAL}

Este capítulo apresenta a descrição detalhada dos procedimentos que foram executados para a obtenção dos dados necessários ao desenvolvimento dos objetivos propostos no trabalho. Serão explicitados os parâmetros significativos necessários ao estudo, às escolhas dos horários e trajetos de captação dos dados e as razões para essas escolhas. Inclui também as formas como foram realizadas a medição da emissão de $\mathrm{CO}$ e $\mathrm{HC}$, o deslocamento e a posição do veículo, consumo por tramo e uma descrição dos equipamentos utilizados.

Ao final, apresentam-se os procedimentos realizados na transformação dos dados brutos, isto é, aqueles coletados no campo, para a obtenção dos dados num formato adequado para estudo.

Enfoca-se, principalmente, como foram processados os dados coletados pelo GPS e pelo analisador de gases e como eles foram reunidos em um mesmo banco de dados para serem analisados de forma conjunta. Foram feitos inicialmente 40 ensaios em 10 dias, sendo perdido no total 6 ensaios e posteriormente mais 10 ensaios em 5 dias, não sendo perdido nenhum ensaio.

\subsection{Delimitação da área de estudo}

O objetivo do trabalho é estudar indicadores de poluição de gases emitidos por veículos automotores, com o motor ainda frio, em trajetos curtos, que são mais significativos em cidades de pequeno e médio porte. A cidade de São Carlos se enquadra nessa característica, portanto, a pesquisa foi desenvolvida nesse município.

São Carlos localiza-se no interior do estado de São Paulo, na região Sudeste do Brasil. Ocupa uma área total de: $1.132 \mathrm{~km}^{2}$ (IGC) / 1.140,92 km² (IBGE), sendo urbanas $67,25 \mathrm{~km}^{2}-6 \%$ da área total. $A$ área urbana efetivamente ocupada é de $33 \mathrm{~km}^{2}$. O município contém 218.702 habitantes pelo IBGE de 2006, sendo $4,9 \%$ nas áreas rurais e $95,1 \%$ nas áreas urbanas, e sua taxa de crescimento demográfico é de $2,4 \%$ ao ano. 
Considerada uma cidade de porte médio, possui uma frota de aproximadamente 100.670 veículos (SOUFEN JR.; TOLEDO, 2007). A evolução da frota de veículos entre 2004 e 2005 foi de 6,7\%. Em São Carlos, o crescimento da frota foi maior que a média estadual, chegando a $20 \%$ entre 2002 e 2005. Em Ribeirão Preto, a frota cresceu $17,2 \%$ e, em Campinas, o aumento de veículos foi de $16 \%$. Assim, percebe-se que a frota de veículos cresce mais aceleradamente que o crescimento demográfico, o que permite inferir o aumento de problemas tanto no que se refere ao trânsito quanto à poluição.

A situação geográfica da região central da cidade é centrada no ponto de coordenadas:

- $22^{\circ} 02^{\prime}$, latitude sul;

- $47^{\circ} 55^{\prime}$, longitude oeste;

- Altitude média de 856 metros.

Grande parte da área urbana de São Carlos se situa em relevo acidentado, com leves colinas que se formam entre os rios Gregório e Monjolinho. Em algumas regiões mais afastadas do centro encontra-se relevo menos acidentado. Esta configuração morfológica da área urbana, com depressões circundadas por áreas elevadas, limita a circulação das massas de ar, o que, juntamente com a escassa vegetação existente, contribui para elevar as temperaturas médias, podendo formar ilhas de calor e de poluição.

A figura 3.1.1 apresenta o mapa geral da área urbana do município de São Carlos, onde estão marcados em verde os trajetos realizados no ensaio. Nesses trajetos estão concentradas as maiores atividades comerciais da cidade. O sistema viário da cidade caracteriza-se por uma malha ortogonal de ruas e avenidas paralelas às direções norte-sul e leste-oeste. 


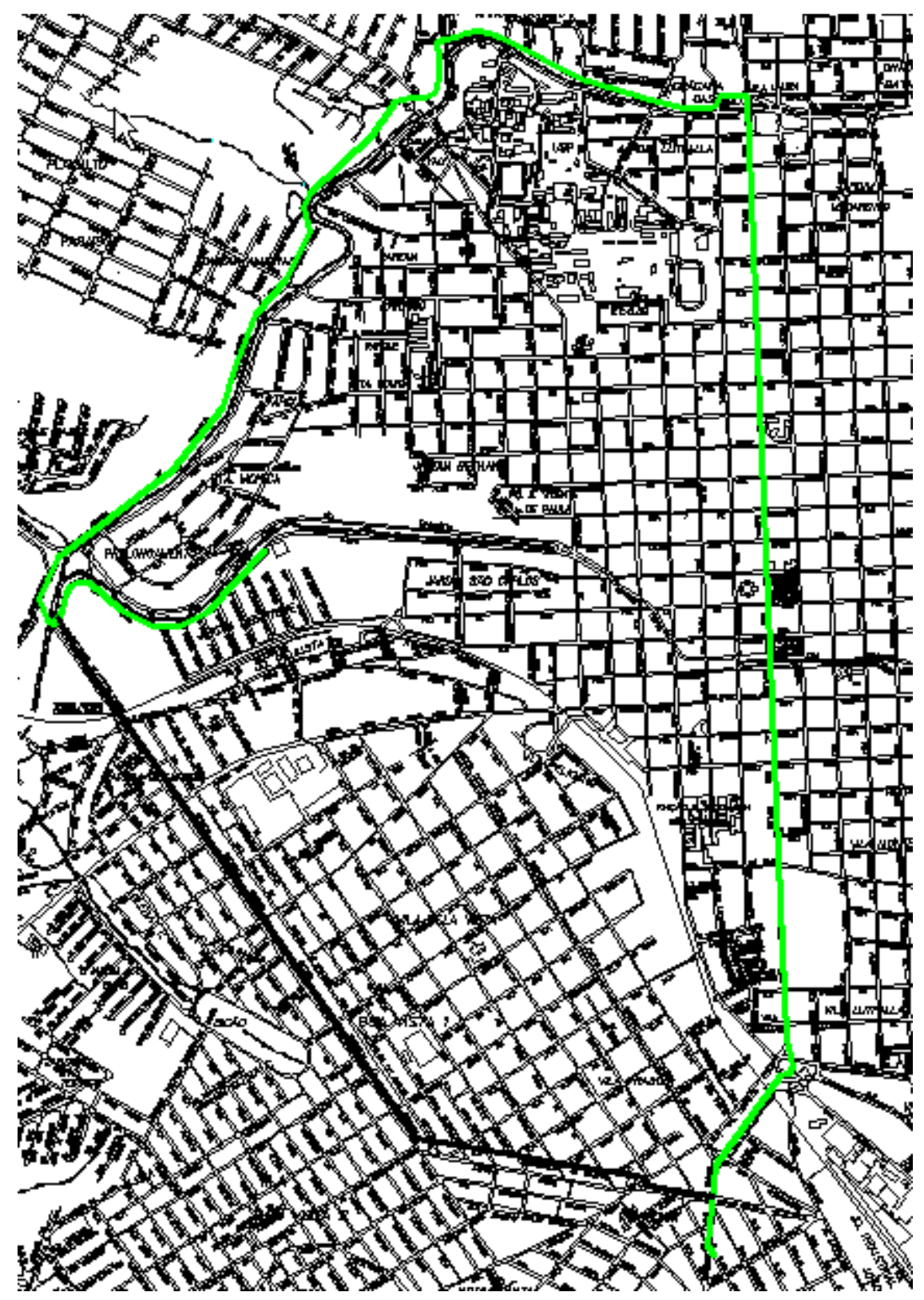

Figura 3.1.1 - Mapa geral do município de São Carlos. Em verde, o trajeto referente a um dos ensaios.

Foram escolhidos trechos das vias que proporcionassem as mais variadas situações de trânsito e topografia para que os dados colhidos fossem significativos para o experimento. Essas escolhas foram baseadas principalmente no fluxo de veículos ao longo dos trajetos, na densidade demográfica do entorno e em trajetos que atravessassem regiões com grande probabilidade de concentração de $\mathrm{CO}$ e HC. Normalmente, ocorre maior concentração de gases nas regiões onde o tráfego intenso de veículos gera maiores emissões de gases, cuja dispersão fica dificultada em razão da concentração de edificações elevadas. 


\subsection{Coleta de dados}

\subsubsection{Variáveis Relevantes}

Muitas variáveis afetam no acúmulo de $\mathrm{CO}$ e $\mathrm{HC}$ em uma região urbana, por exemplo, o número dos veículos automotores que trafegam na região, os tipos desses veículos, a forma como esses veículos são conduzidos, as manutenções a que são submetidos ou não, a idade média da frota, a velocidade média, a topologia das edificações e das vias de trânsito, as variáveis do microclima, as sinalizações de trânsito, dentre outras. Apenas os parâmetros de maior relevância e cuja mensuração seja possível fazer, com um nível razoável de precisão, serão coletados. As variáveis mais relevantes consideradas são:

- Os perfis geométricos dos trajetos. Esses perfis são essencialmente os dados geométricos da curva espacial determinada ao longo do tempo, pelo veículo em estudo. Esses dados permitem, por exemplo, o cálculo da velocidade e da aceleração do veículo ao longo do trajeto. O acoplamento do GPS ao computador com o auxílio dos dados do GPS fixo possibilitou obter esses dados com a precisão desejada. Os trajetos foram escolhidos para que fossem representativos da região em estudo, permitindo que a análise dos dados seja significativa.

- A emissão de CO e HC. Essas emissões foram mensuradas em intervalos de tempo bastante pequenos para se chegar a uma função representativa total ou em partes, serão eventualmente correlacionadas com outras curvas que descrevem aspectos geométricos do trajeto bem como com outros dados colhidos, como o consumo do veículo feito com o computador de bordo.

- Temperatura do motor do veículo. A temperatura foi mensurada através de um termopar colocado no lugar da vareta de verificação do nível de óleo do motor. Com isso, pode-se avaliar a temperatura tanto quando o motor do carro estava ainda em fase de aquecimento, quanto quando ele já estava considerado aquecido.

Apesar de não ser uma das variáveis mais relevantes para a pesquisa, também a topologia do entorno foi analisada e, a partir disso, utilizada na pesquisa para estabelecer inicialmente o trajeto que seria percorrido durante a 
pesquisa. Assim, por meio de mapas e fotos aéreas da cidade e também pela verificação visual, que proporcionaram dados a respeito de edificações, sinalizações e obstáculos ao longo do trajeto, foi possível determinar o trajeto a ser estudado.

Outro fator relevante para o desenvolvimento da pesquisa é a qualidade do combustível utilizado. Assim, para se aferir a gasolina com que o veículo foi abastecido durante os testes, uma amostra foi coletada no momento do abastecimento anterior à realização dos ensaios. Essa amostra foi encaminhada ao Centro de Caracterização e Desenvolvimento de Materiais da Universidade Federal de São Carlos - UFSCar / Universidade Estadual Paulista - UNESP, que emitiu um relatório anexado ao final deste trabalho (anexo II). O resultado indica que o combustível utilizado atendia a todas as normas vigentes, o que o credencia a validar os valores referenciais obtidos nos ensaios.

As coletas foram feitas nos períodos matutinos e vespertinos, sempre se iniciando na mesma hora (aproximadamente às 8 h30 e 17h30) e executadas repetidas vezes mantendo-se uma rotina de coleta para confirmação dos padrões obtidos. Os dois percursos básicos a serem percorridos desenvolviam-se em locais mais movimentados e em situações com mais rampas, semáforos e obstáculos. Foram feitos 40 ensaios em 10 dias, sendo realizado 4 ensaios por dia, dois no período da manhã e dois no período da tarde, sendo o primeiro ensaio com motor frio, e o segundo ensaio com motor aquecido em cada um dos períodos. Foram feitos posteriormente mais 10 ensaios da mesma forma que descrito anteriormente para complementar alguns dados.

Inicialmente, com o motor frio, era feito um percurso mais longo, que incluía, ao final, trechos em vias de acesso rápido. Ao terminar o primeiro ensaio, aqueciam-se mais o motor e retornava-se a um ponto médio do primeiro percurso para que o mesmo trecho (o trecho mais movimentado e com mais rampas) fosse percorrido novamente, desta vez com o motor já aquecido. O objetivo era verificar a variação da emissão de gases com o motor frio e com o motor aquecido nessas situações.

Logo em seguida, o carro permanecia estacionado por cerca de $8 \mathrm{~h}$, para que o motor esfriasse novamente, e o ensaio era repetido, da mesma forma, por volta das $17 \mathrm{~h} 30$. 
Esses procedimentos metodológicos são apresentados em um esquema geral, na figura 3.2.1, que resume as sequências aplicadas no trabalho e descritas neste capítulo.

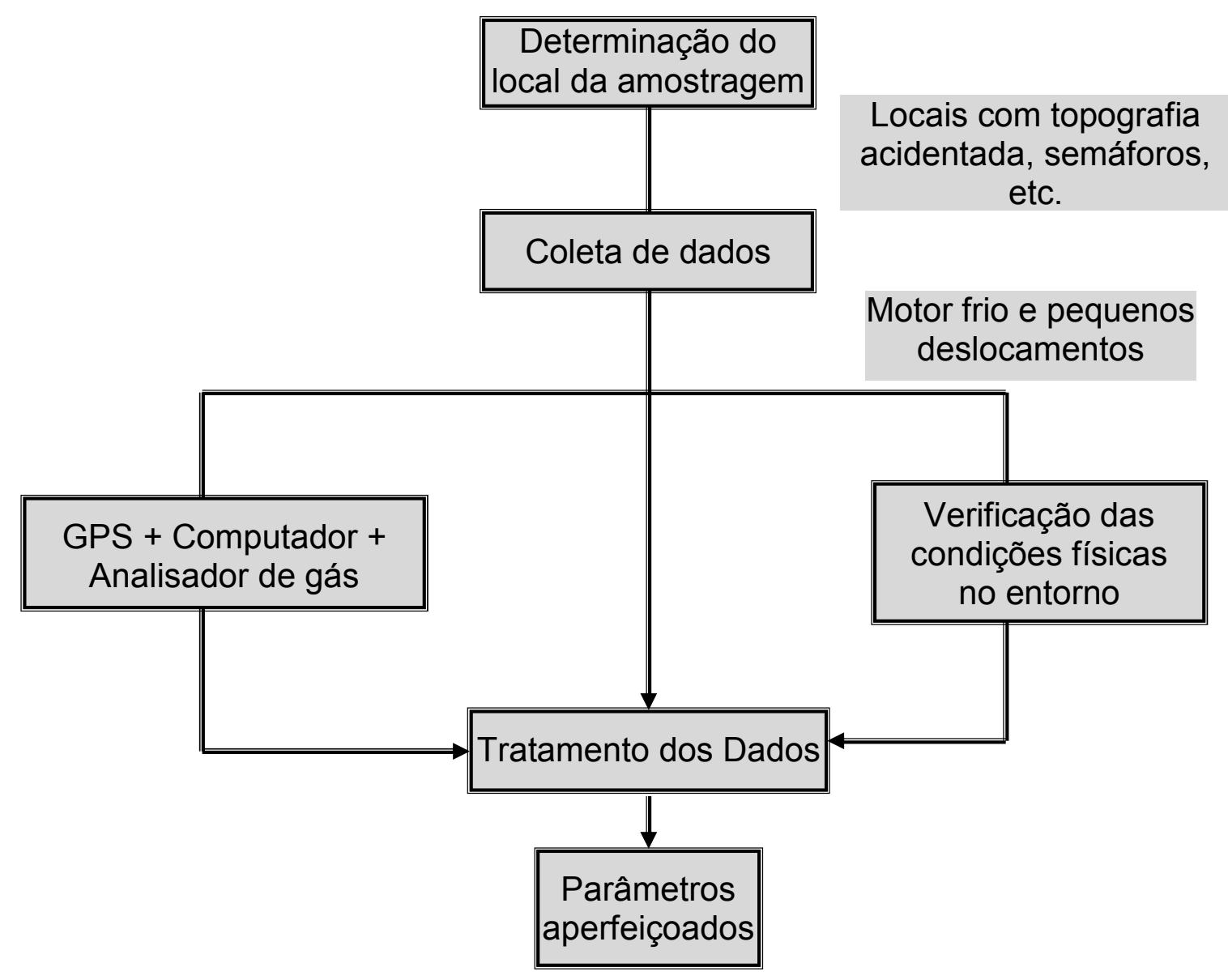

Figura 3.2.1 - Sequência dos procedimentos para realização do trabalho

\subsubsection{Equipamentos e programas}

Decidiu-se usar na coleta dos dados apenas um carro, pois, o objetivo do trabalho era desenvolver uma metodologia de ensaios sobre emissão de $\mathrm{CO}$ e HC de acordo com os parâmetros pré-determinados e que não incluía testar a variação da metodologia em função do modelo ou marca do veículo. O carro escolhido para os ensaios foi o de uso pessoal. Antes dos testes, o veículo passou por uma revisão geral e foi testada sua emissão de $\mathrm{CO}$ e $\mathrm{HC}$ pela empresa Tecnomotor Eletrônica do Brasil, de acordo com as normas vigentes, tendo sido aprovado em todos os testes. O veículo é da marca FIAT, modelo Pálio, ano 2004, 
com motor de $1.3 \mathrm{l}$ flex, com aproximadamente $90.000 \mathrm{~km}$ rodados, pneus novos e a maioria dos componentes revisados e originais.

Inicialmente, as coletas de dados relativas à posição e deslocamento do veículo seriam obtidas a partir de um aparelho de GPS marca Leica, modelo GS-20, com sistema de correção em tempo real, com as antenas sobre o veículo em deslocamento. A antena de link receberia dados relativos às correções de localização em tempo real da sua posição e corrigiria a posição obtida através da antena do sistema GPS. O método foi abandonado porque o equipamento era emprestado do Departamento de Hidráulica e Saneamento da USP de São Carlos e o serviço de receber as correções em tempo real se expirou. Os custos para reativar o sistema eram altos.

Em seguida, optou-se por usar o mesmo equipamento GPS, mas usando outro método de processamento, denominado método relativo. Os dados de posição do carro em movimento foram coletados no próprio receptor GPS Leica GS-20 e descarregados em um programa de processamento. Esse método exige outra antena de GPS fixa coletando dados simultaneamente. Como o Departamento de Transporte possui um GPS topográfico fixo coletando dados de forma contínua, foi apenas necessário fazer a coleta simultânea com os parâmetros compatíveis. Esse método funcionou bem e alcançou uma precisão muito boa.

Com a desativação da AS (Selective Availability: degradação intencional dos sinais GPS pelo governo americano enquanto o sistema era mantido pelos militares, de modo a dificultar que pessoas não autorizadas utilizassem o sistema com precisão), a utilização de receptores GPS de navegação está se tornando cada vez mais popular. Esses receptores, no entanto, estimam e armazenam as posições, mas não registram as observáveis (pseudodistâncias e/ou fase da portadora L1), o que inviabiliza um pós-processamento dos dados necessários neste trabalho.

Foram encontrados dois programas que são capazes de armazenar as observáveis dos receptores GPS de navegação Garmin. Isso motivou o teste do procedimento anterior, substituindo o GPS Leica GS-20 (equipamento relativamente caro) por um GPS da marca Garmin, modelo Map 12, usado para navegação, com antena externa, disponível no Departamento de Transporte. Para se alcançar a precisão necessária com o uso desse equipamento é necessária utilizar o método de posicionamento relativo cinemático processado com o código. 
Para isso foi necessário um computador como coletor de dados e um dos programas que armazenasse as observáveis.

Como coletor de dados foi usado um computador portátil, modelo Acer 3000, com bateria de duração aproximada de uma hora, o que possibilitou fazer os testes sem a necessidade de usar fonte externa de energia.

O Instituto de Engenharia de Levantamento e Geodésia Espacial (IESSG) da Universidade de Nottingham desenvolveram o programa comercial Gringo (GPS Rinex Generator) para extrair e registrar as observáveis da portadora L1 dos receptores GPS de navegação da marca Garmin. Esse programa foi desenvolvido para ser usado com receptor GPS Garmin 12XL e, segundo informações técnicas do vendedor, ele poderia ser usado com a maioria de modelos de receptores GPS de 12 canais.

Antes de se iniciar a coleta, é possível definir alguns parâmetros, como, por exemplo, altura e tipo de antena e taxa de observação (1s, 5s, 10s, etc.). Os dados decodificados do receptor GPS de navegação são transmitidos para o computador em linguagem proprietária, via porta serial, em tempo real, e gravado no disco rígido do computador portátil. O software decodifica esses dados para gerar um arquivo no formato Rinex (Receiver Indepedent Exchange). Com esse arquivo e um programa de processamento GPS, pode-se processar os dados, visando a melhorar o posicionamento do receptor GPS de navegação.

O programa foi comprado e instalado em um notebook para realização dos testes. Obtiveram-se resultados muito satisfatórios. Para tentar melhorar ainda mais os resultados, buscou-se utilizar um GPS de navegação com antena mais sensível à captura de sinais. Comprou-se o GPS da marca Garmin, modelo 60csx. Porém, o programa Gringo não conseguiu sincronizar-se com esse equipamento, não sendo possível utilizá-lo nos ensaios.

Além disso, quando ao ser reinstalado em outro notebook que seria usado nos testes de campo, o programa deixou de funcionar. Devido à dificuldade em se obter assistência técnica para o programa, optou-se por usar o programa Async, que é disponível sem custos. O Async só é compatível com os GPS Garmin Map 12 e Etrex e como os dois modelos de GPS estavam disponíveis, optou-se por usá-los nos testes. 
O Async foi desenvolvido pelo Professor Antonio Tabernero Galan, da Universidade Politécnica de Madri, Espanha (GALAN, 2001). É um programa disponível na internet, que é capaz de ler e registrar em arquivos binários as observáveis GPS da portadora L1, transmitidas pela porta de comunicação do aparelho receptor Garmin ao computador, via cabo serial. O notebook, porém, não possuía porta serial. Foi necessário adaptar um cabo conversor de serial para USB.

A figura 3.2.2.1 apresenta os comandos dados no programa Async para fazer a coleta de dados

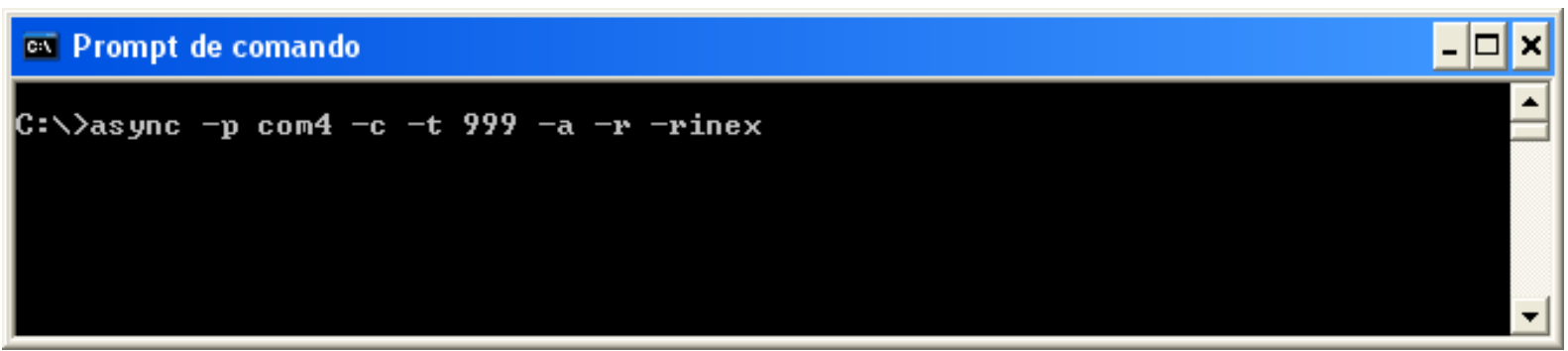

Figura 3.2.2.1 - Tela do programa Async

Posteriormente à coleta de dados do GPS, utilizou-se o programa, GAR2RNX que promove a conversão do arquivo binário dos dados gerados no Async em arquivos de texto no formato Rinex. Sendo assim, foi possível o pós-processamento dos dados para o cálculo de coordenadas dos pontos.

O segundo aparelho GPS estava fixado no Departamento de Transportes e coletou dados simultaneamente durante cada período de ensaio. É um aparelho da marca Novatel acionado via assistência remota, através da internet. Esse GPS estava ligado a um computador com o programa GPSolution e armazenou os dados em um arquivo do computador, que depois foram convertidos em Rinex para o processamento.

A figura 3.2.2.2 ilustra a tela do programa GPSolution, mostrando o sinal de quantos satélites estão sendo coletados. 


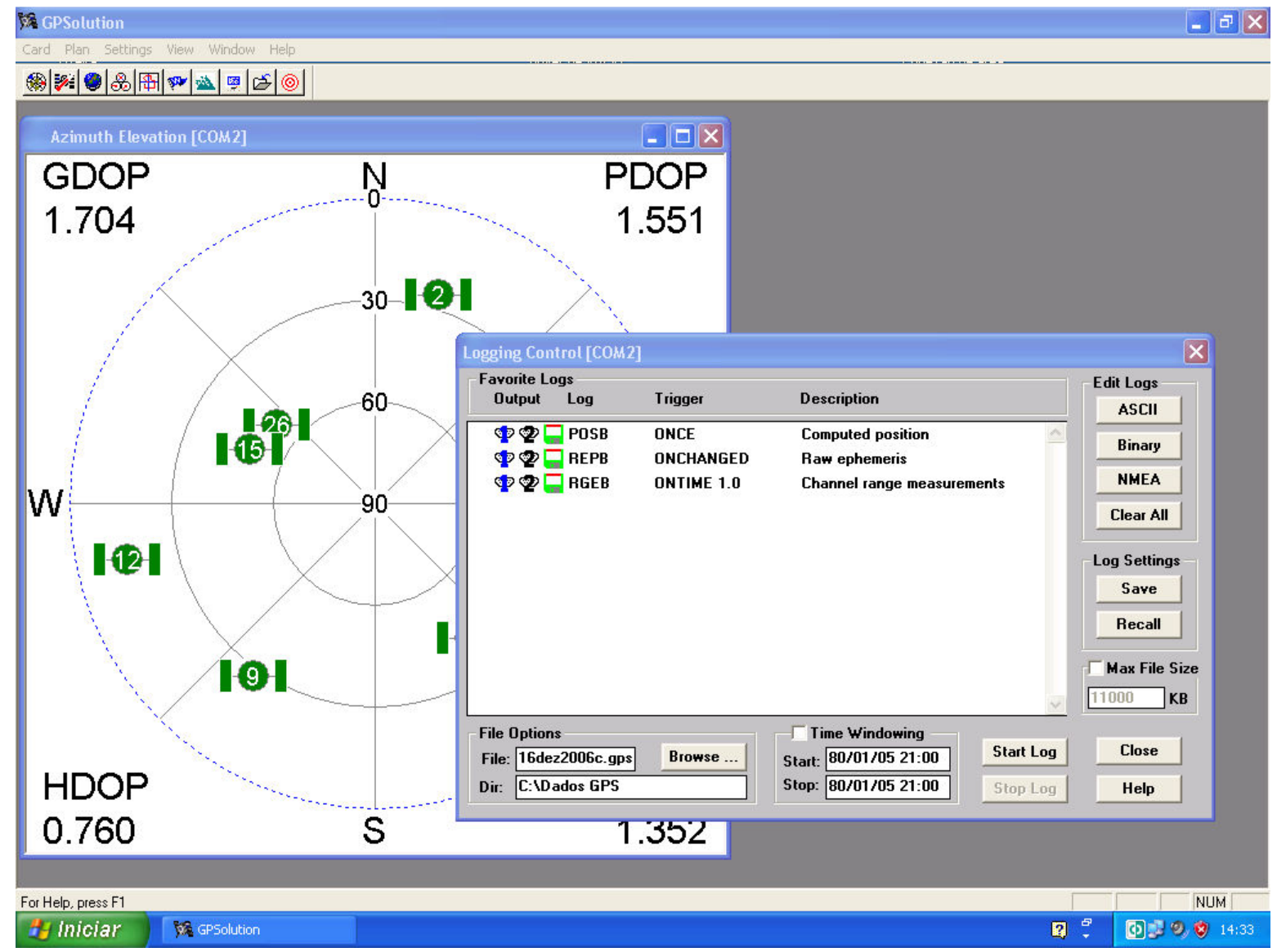

Figura 3.2.2.2 - Tela do programa GPSolution

Como os resultados se mostraram satisfatórios, optou-se por fazer os ensaios definitivos com o GPS Garmin Map 12 e com o programa Async e com os dados da antena GPS Novatel.

Também foi utilizado na pesquisa um analisador de gás, para se analisar a qualidade dos gases emitidos pelo motor do veículo nas condições préestabelecidas na pesquisa e verificar sua alteração durante o trajeto. Existem muitos fabricantes de analisadores de gás portáteis. Várias empresas foram consultadas sobre a possibilidade de emprestarem o equipamento para a realização dos testes, já que o custo de aquisição do equipamento era muito alto.

A empresa Napro permitiu um ensaio usando seu equipamento, na cidade de Ribeirão Preto, porém não poderia fazer o empréstimo para os testes por tempo prolongado. A empresa de São Carlos, Tecnomotor, disponibilizou um equipamento para a realização dos testes, que foi o utilizado durante a pesquisa. $O$ modelo de analisador de gás emprestado foi o TM 132, que analisa os gases através de infravermelho (células químicas), que faz as leituras de emissão de CO com sensor colocado no escapamento do veículo e tem as seguintes características: 
A tabela 3.2.2.1 resume as características do TM 132:

Tabela 3.2.2.1 - Tabela das características do analisador de gás TM 132 utilizado

\begin{tabular}{|c|c|c|c|c|c|}
\hline & & \multicolumn{2}{|c|}{ Faixa } & Resolução & Precisão (faixa) \\
\hline & & Mínimo & Máximo & \multirow{3}{*}{$1 \mathrm{ppm}$} & \multirow{3}{*}{12 ppm } \\
\hline \multirow{2}{*}{$\mathrm{HC}$} & Hexano & 0 & 20.000 ppm & & \\
\hline & Propano & 0 & 40.000 ppm & & \\
\hline \multicolumn{2}{|r|}{$\mathrm{CO}$} & 0 & $15 \%$ & $0.01 \%$ & $0.06 \%$ \\
\hline \multicolumn{2}{|r|}{$\mathrm{CO}_{2}$} & 0 & $20 \%$ & $0.01 \%$ & $0.05 \%$ \\
\hline \multicolumn{2}{|r|}{$\mathrm{O}_{2}$} & 0 & $25 \%$ & $0.01 \%$ & $0.1 \%$ \\
\hline \multirow{3}{*}{\multicolumn{2}{|c|}{$\mathrm{NO}_{x}(\mathrm{NO})$}} & \multirow{3}{*}{0} & \multirow{3}{*}{5.000 ppm } & \multirow{3}{*}{$1 \mathrm{ppm}$} & 32 ppm a $(0-1.000)$ \\
\hline & & & & & 60 ppm a (1.001-2.000) \\
\hline & & & & & 120 ppm a (2.001-4.000) \\
\hline \multicolumn{2}{|c|}{ Rotação (pinça indutiva) } & 200 & 10.000 ppm & $1 \mathrm{rpm}$ & 10 rpm \\
\hline \multicolumn{2}{|c|}{ Temperatura } & $-10^{\circ} \mathrm{C}$ & $140^{\circ} \mathrm{C}$ & $1^{\circ} \mathrm{C}$ & $\pm 2^{\circ} \mathrm{C}$ \\
\hline
\end{tabular}

Fonte - Adaptado de Tecnomotor (2002)

Foram realizados vários testes estáticos que serviram para decidir a melhor maneira de se coletar os dados, ter uma referência inicial das emissões e conferir o tempo que o veículo demorava a aquecer. Os testes estáticos com motor a frio foram feitos na própria empresa Tecnomotor. O veículo era deixado na empresa na tarde anterior ao teste e no dia seguinte, com o motor frio, no período da manhã eram realizados os testes. Os testes estáticos foram úteis e forneceram informações importantes sobre como o equipamento deveria ser usado nos testes dinâmicos. O contato com o equipamento nesta fase permitiu adotar soluções para o adequado acoplamento dos equipamentos no veículo em movimento.

Foram feitos, posteriormente, testes dinâmicos apenas com o analisador, com a finalidade de se aprimorarem os acoplamentos citados. Nos testes dinâmicos, o analisador de gases foi acoplado ao mesmo notebook a que foi acoplado o GPS, através de outra porta USB. Foi instalado um programa que armazenava os dados colhidos pelo analisador, chamado SoftGas. Nesse programa, os dados são apresentados em um gráfico.

A figura 3.2.2.3 ilustra a tela do programa SoftGas. A coleta de dados fica armazenada de acordo com o dia e a hora da amostragem. 


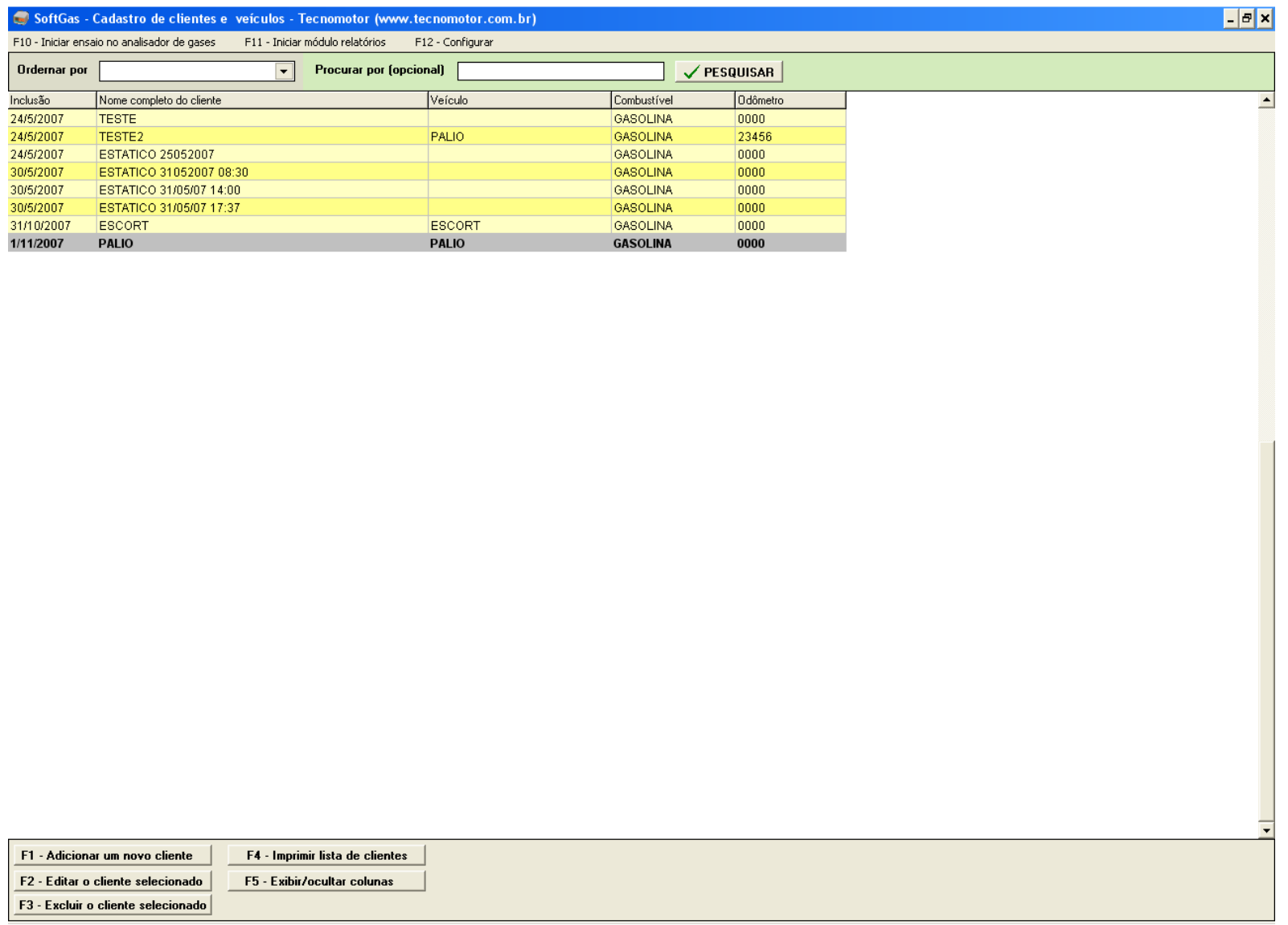

Figura 3.2.2.3 - Tela do programa Softgas

Como não foi possível acoplar diretamente o computador de bordo do carro ao notebook, foi desenvolvido um programa que coletava os dados em tempo real e os armazenava em um banco de dados. A cada mudança de variação de consumo (aproximadamente a cada 3 segundos) uma segunda pessoa digitava no programa manualmente os dados de consumo. Esse programa armazenava os dados em formato texto e posteriormente foram inseridos no banco de dados geral no Excel. O nome do arquivo seguia uma regra para os dados não ficarem perdidos. Os 3 primeiros dígitos indicavam o dia GPS, seguido de m para período da manhã e t para período da tarde. Se fosse com o motor frio, era seguido da letra $f$, se estava aquecido, era seguido da letra q.

A figura 3.2.2.4 ilustra a tela do programa, desenvolvido pelo Professor Ricardo Schaal para facilitar essa coleta de dados. Na tela do programa instruções de como usá-lo e conforme os dados eram inseridos, era possível ver na tela se algum dado havia sido digitado errado. 


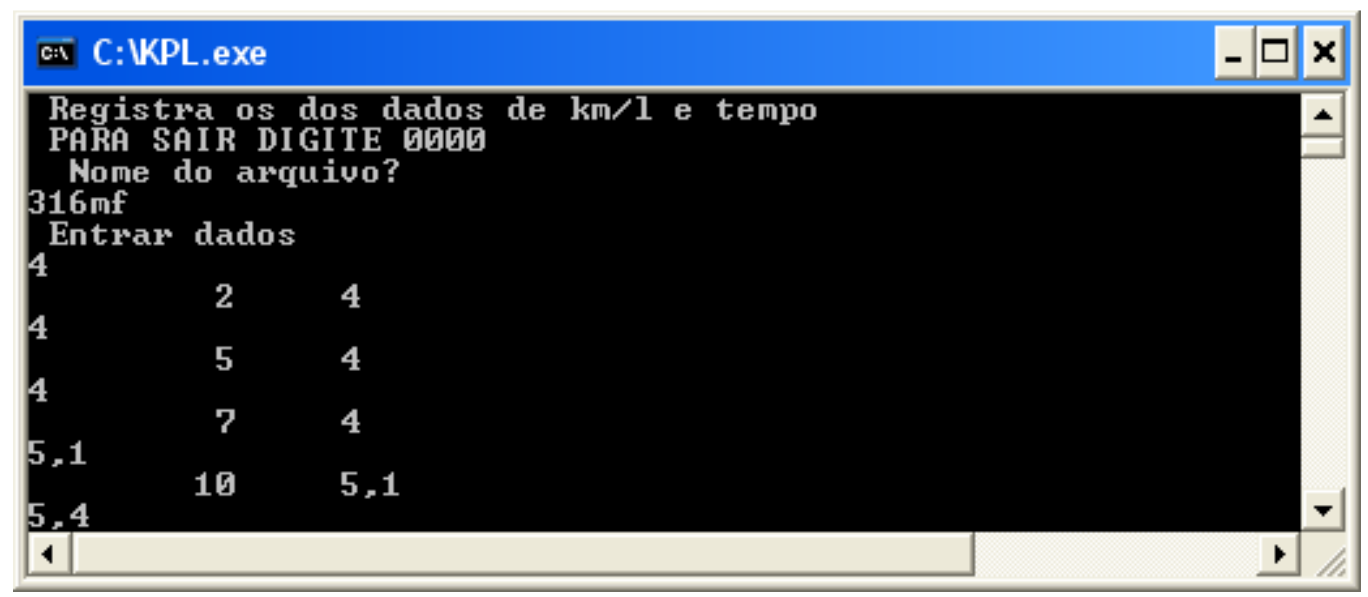

Figura 3.2.2.4 - Tela do programa KPL

A figura 3.2.2.5 ilustra a saída de dados do programa $\mathrm{KPL}$, que era editado no bloco de notas, e depois, inserido na planilha Excel com os outros dados coletados.

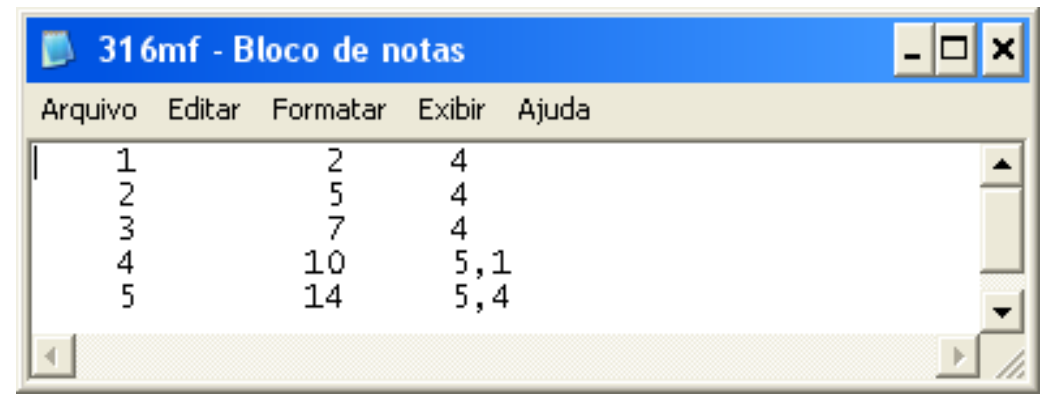

Figura 3.2.2.5 - Resultados do programa KPL para serem exportados para planilha Excel

A primeira coluna era apenas um contador; a segunda coluna era o tempo em segundos desde que o programa era ligado e a terceira coluna eram os valores de consumo digitados pelo ajudante.

\subsubsection{Montagem dos equipamentos}

A colocação e a montagem dos equipamentos no veículo foram feitos de tal modo que pudesse transitar normalmente sem danificar os equipamentos ou perturbar a coleta dos dados. O receptor GPS foi ligado a uma antena externa que ficava no teto do veículo preso por um ímã e um cabo com adaptador o ligava ao notebook. 
A figura 3.2.3.1 ilustra o notebook ligado ao GPS. Uma antena GPS acoplada a um ímã era fixa no teto do veículo.

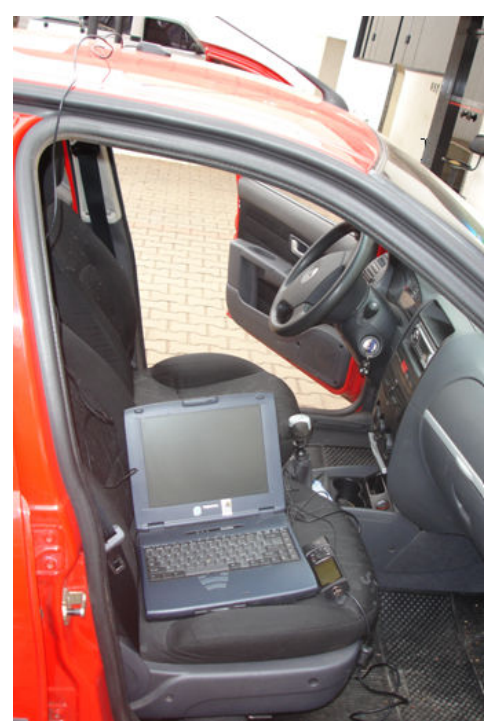

Figura 3.2.3.1 - Foto do GPS ligado ao notebook e a antena externa

No escapamento do veículo, foi colocada a sonda coletora de gases, junto a uma garra metálica que a prendia no terminal do escapamento. Posteriormente, era passada uma fita adesiva para garantir que a sonda se mantivesse fixa. A cada teste, a mangueira era solta do analisador de gases e do escapamento para se retirar acúmulo de água.

A figura 3.2.3.2 ilustra a fixação da sonda no escapamento.

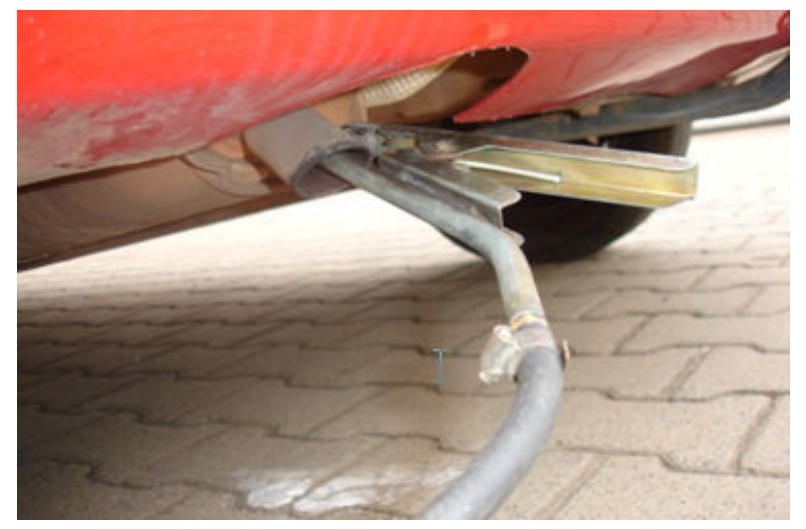

Figura 3.2.3.2 - Detalhe da sonda ligado ao escapamento do carro

É importante notar que a mangueira que alimenta o analisador de gases, que sai do escapamento do carro e vai até o analisador, teve seu 
comprimento reduzido ao máximo para não afetar no tempo de coleta de dados, isto é, procurou-se diminuir ao máximo o retardamento existente entre a emissão do poluente e sua detecção pelo aparelho analisador, como fica claro na figura 3.2.3.3.

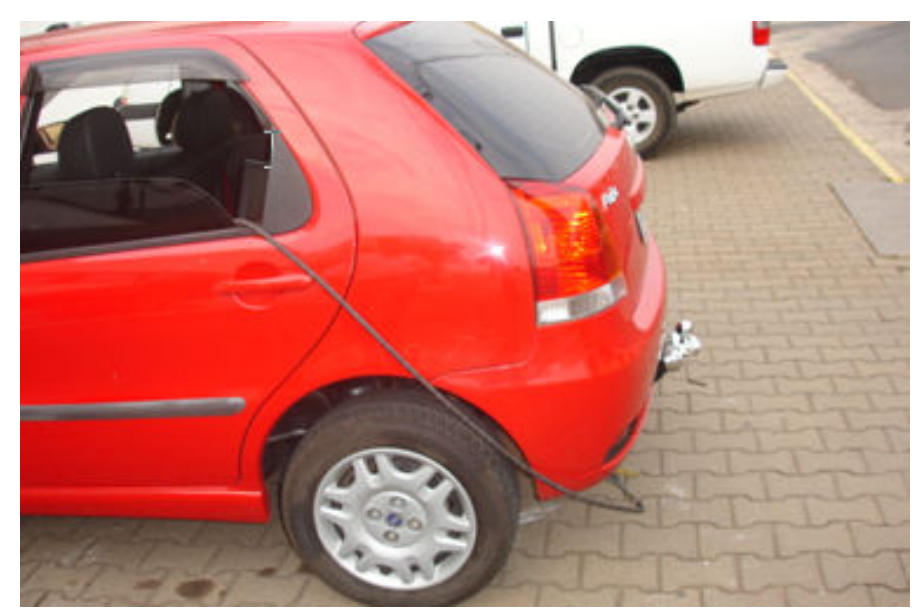

Figura 3.2.3.3 - Comprimento da mangueira de teste

Um termopar foi colocado no local da vareta de nível de óleo do motor e era gravado no analisador de gases durante os testes como mostra a figura 3.2.3.4. Atentava-se para sempre introduzir o termopar na mesma profundidade.

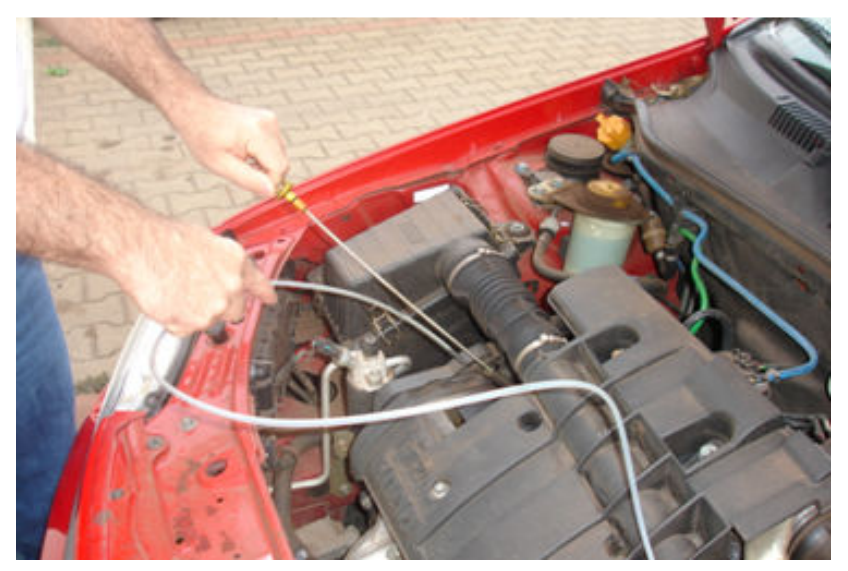

Figura 3.2.3.4 - Termopar para medição da temperatura do óleo do motor

A figura 3.2.3.5 ilustra o analisador de gases que ficava no banco de trás ligado ao notebook. A mangueira que ligava o analisador no escapamento passava pela janela, que sempre ficava um pouco aberta para essa passagem. 


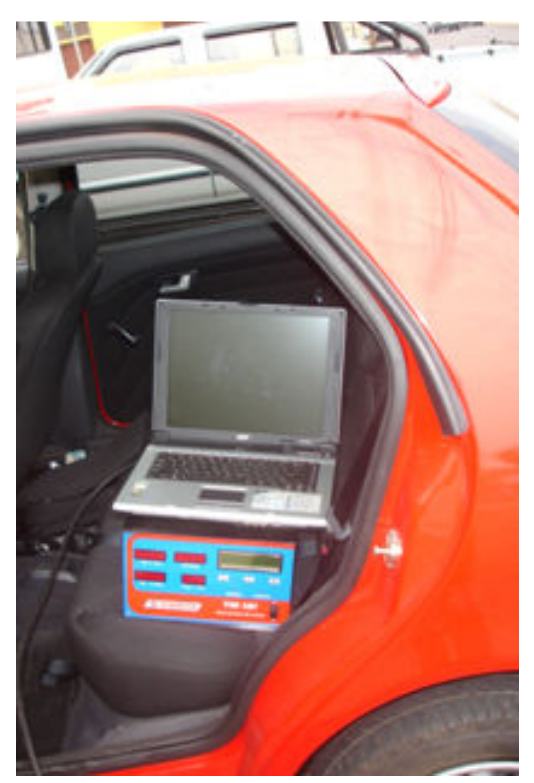

Figura 3.2.3.5 - Analisador de gases ligado ao notebook e ao GPS

\subsubsection{Procedimentos durante o teste}

Em um primeiro momento a coleta de dados do GPS fixo na USP era ligada por assistência remota. Os dados daquela antena deveriam ser obtidos durante todo o período dos testes dinâmicos.

Em seguida, com o notebook ligado, o programa Softgas era aberto e este ligava o analisador de gases. Era necessária uma espera até que o analisador aquecesse. A fonte de energia elétrica deste equipamento era obtida via transformador de voltagem adaptado ao acendedor de cigarros do veículo. O GPS era então ligado, e o programa Async aberto.

Quando o analisador de gases estava aquecido, eram ligadas simultaneamente; a coleta de dados do analisador, pelo Softgas e a coleta de dados do GPS, pelo Async. O GPS e o Analisador de Gases conectados ao mesmo tempo nas portas USB do notebook e ligados ao mesmo tempo junto com o programa KPL para fazer a coleta de dados de consumo instantâneo. No programa KPL, o ajudante entrava com os dados de consumo instantâneo manualmente.

O veículo era, então, ligado e iniciava-se o percurso préestabelecido para cada ensaio. Terminado o percurso, os dados eram salvos em arquivos próprios e os equipamentos eram desligados. O carro retornava para a garagem para o motor esfriar até o próximo ensaio. 


\subsection{Tratamento dos dados e modelagem}

Os dados coletados pelo receptor GPS Garmin Map 12, eram arquivados direto no notebook, dentro do carro em movimento. Esses dados possuem um formato padrão gerado pelo programa Async.

Através do aplicativo gar2rnx.exe, os arquivos gerados pelo Async eram transformados para o formato Rinex, que permite a sua utilização em programas usuais de processamento GPS.

A figura 3.3.1 ilustra a tela do programa gar2rnx transformando um arquivo no formato *.g12 em um arquivo de observação e um arquivo de navegação no formato Rinex. Esses arquivos gerados pelo gar2rnx podem ser posteriormente processados em outro programa de processamento GPS.

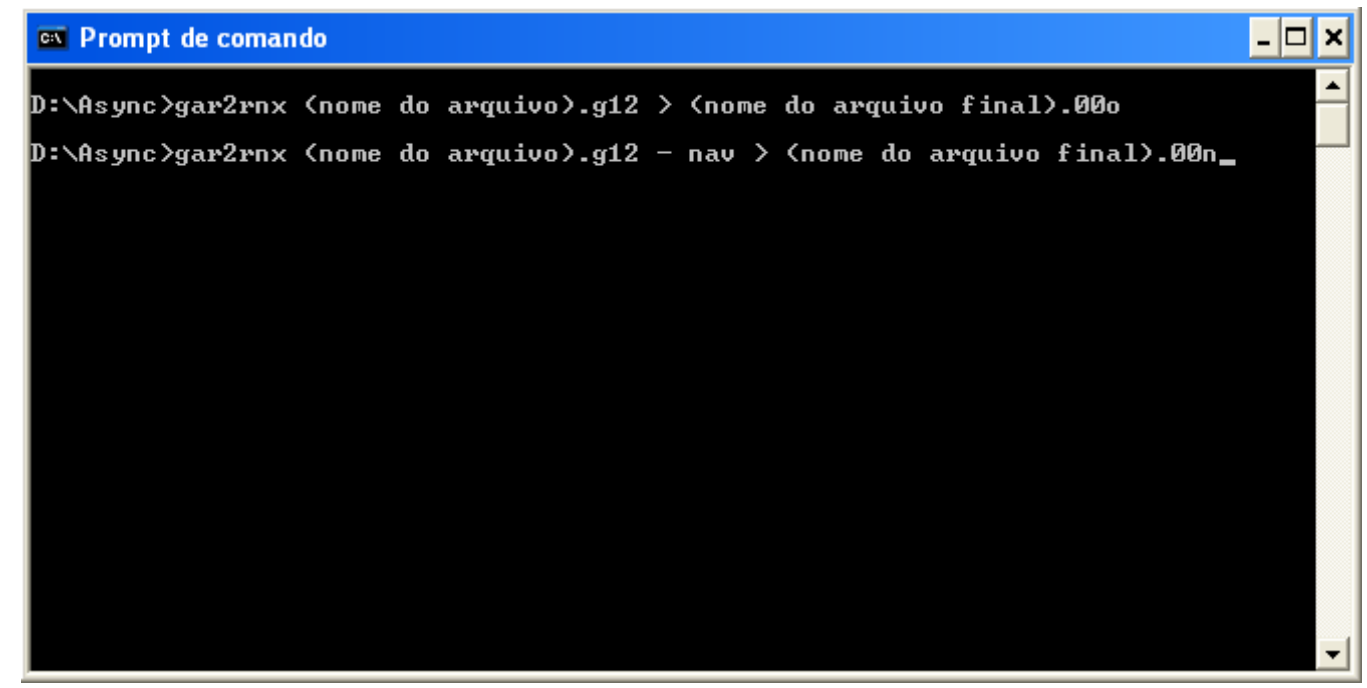

Figura 3.3.1 - Tela ilustrativa dos comandos para transformar os dados *.g12 em Rinex

Simultaneamente às operações de coleta dos dados de localização no carro em movimento, um receptor GPS estático, de marca NovAtel, usando o programa GPSolution, coletava dados para auxiliar no cálculo da localização em conjunto com os dados obtidos pelo GPS no carro em movimento. Esses arquivos eram trazidos por rede do computador que fica armazenando os dados do GPS até o computador usado para o processamento. Através do programa Convert32.exe, os arquivos gerados pelo GPSolution eram também transformados em arquivos Rinex. Esses procedimentos eram repetidos para cada coleta de dados no campo. 
A figura 3.3.2 ilustra a tela do programa Convert32 que transforma os dados gerados pelo programa GPSolution em arquivos Rinex, que podem ser processados em qualquer programa de processamento GPS. Cabe ressaltar que esse procedimento não seria necessário se fosse utilizado uma mesma marca de equipamento GPS. Porém o objetivo era também testar o funcionamento do GPS de navegação coletando dados em um programa capaz de armazenar os dados GPS e depois processá-los referenciados a uma base fixa, procedimento não muito comum e estudado em GPS de navegação.

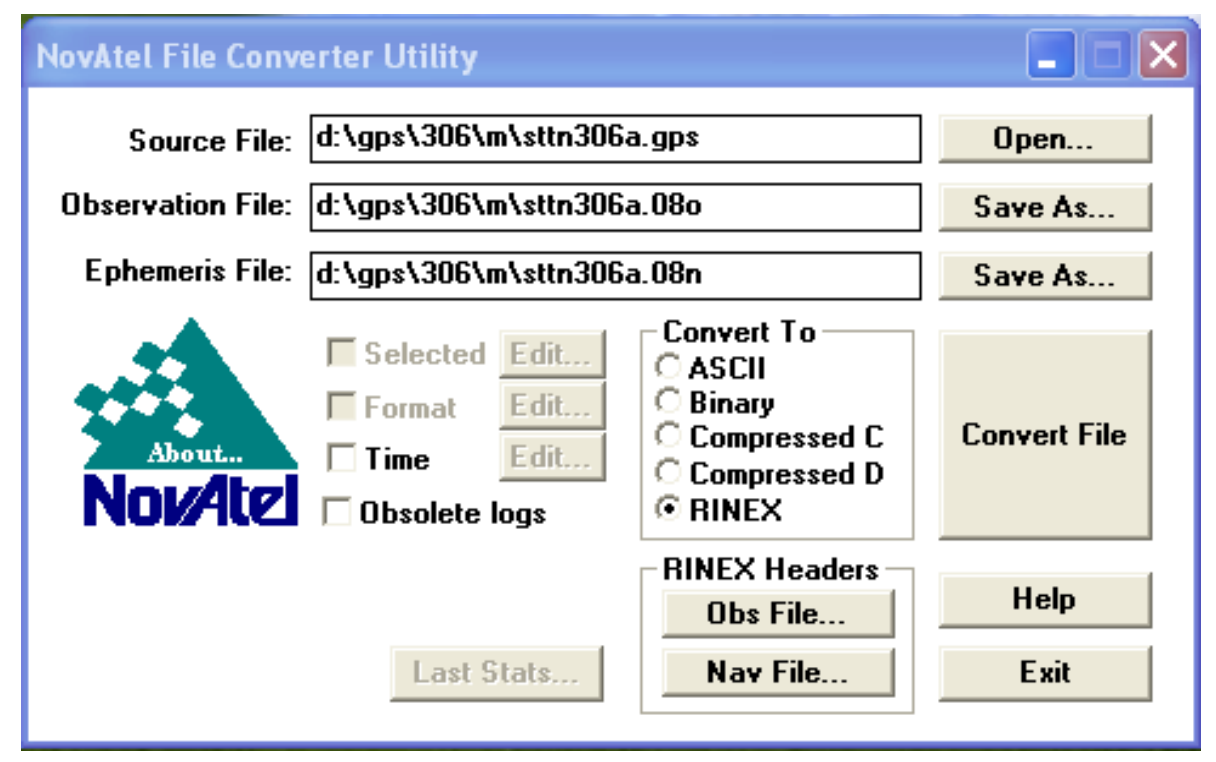

Figura 3.3.2 - Tela do programa Convert32.exe convertendo um arquivo extensão *.gps em Rinex

Como o Departamento de Transportes possui o programa SKI 2.3 da Leica, ele foi escolhido para o processamento dos dados.Sua tela pode se vista na figura 3.3.3. 


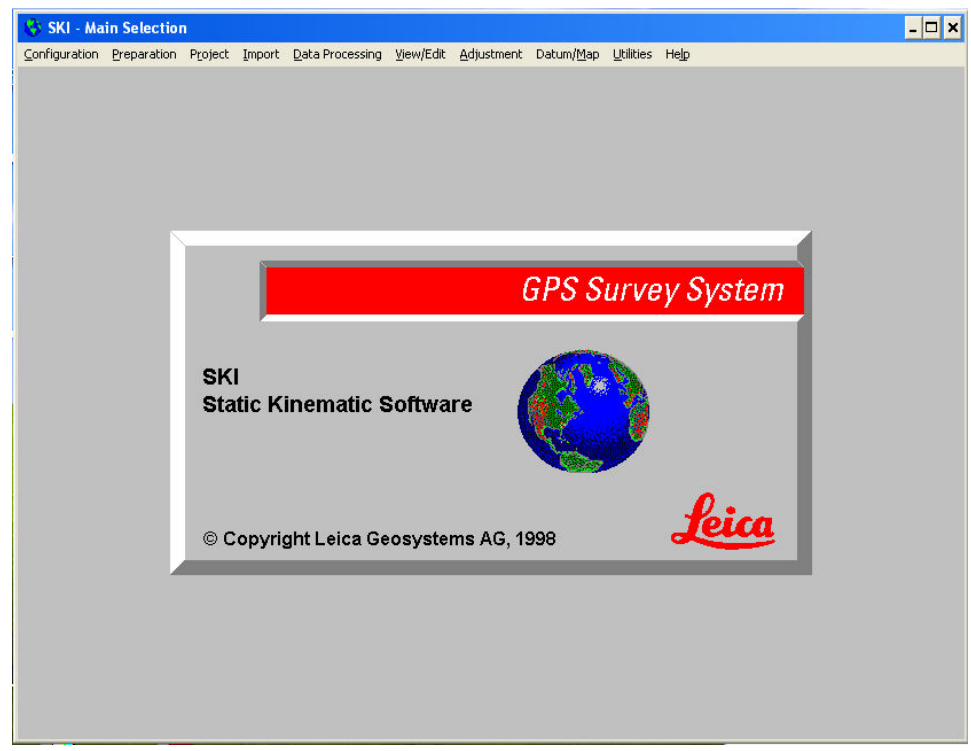

Figura 3.3.3 - Tela do Ski 2.3

A figura 3.3.4 ilustra as configurações utilizadas para fazer o processamento GPS no programa Ski 2.3 .

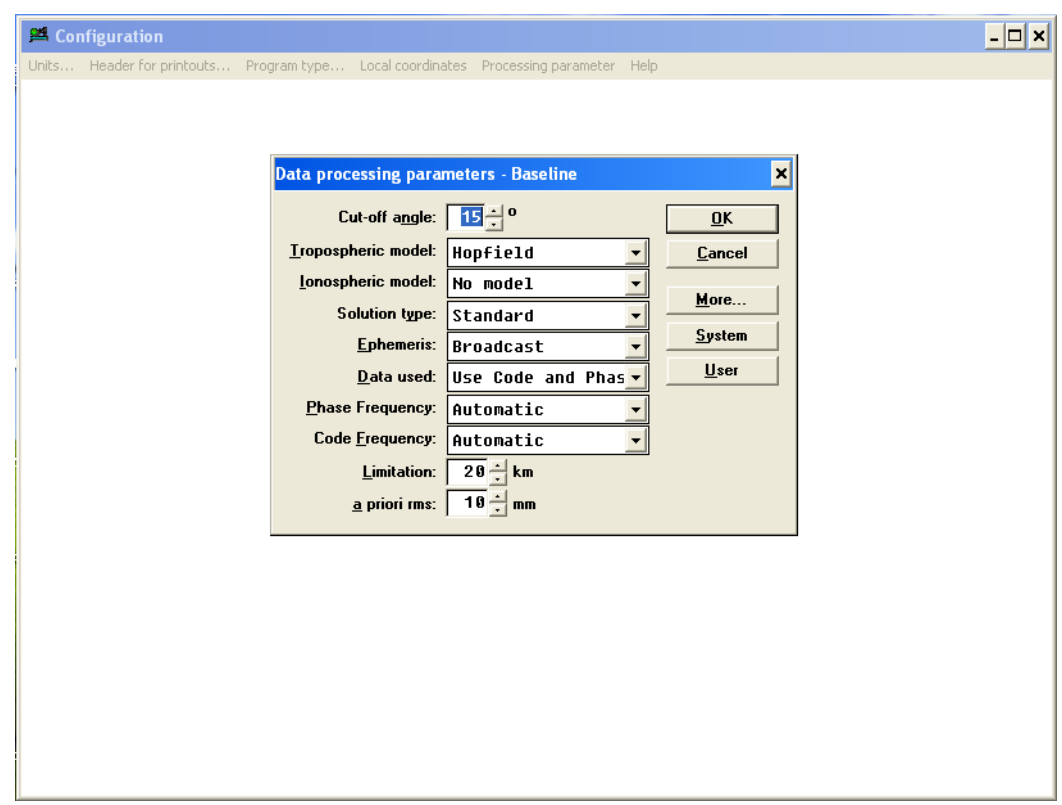

Figura 3.3.4 - Tela de configuração usada no programa Ski 2.3

O programa, porém, não aceita os cabeçalhos Rinex gerados pelo GAR2RNX.exe. Foi necessário alterar todos os cabeçalhos de forma conveniente para que o programa pudesse ser utilizado. Exemplo do arquivo Rinex gerado pelo programa gar2rnx.exe sem alteração: 
2 OBSERVATION FILE GPS NAVSTAR Rinex VERSION / TYPE

GAR2RNX 1.48 Any GPS12 Owner Sun Nov 04 09:12:22 PGM / RUN BY / DATE

${ }^{* *}$ gar2rnx (Garmin to Rinex) generates Rinex2 files COMMENT

** from a GPS12 (or XL) (Copyright Antonio Tabernero) COMMENT

** Generated from G12 data file: $331903 . g 12 \quad$ COMMENT

** Options:

COMMENT

Garmin

Number of Antenna marker

Your name here Your boss here

129 GPS 12 Map Softwar 2.01

o GPS12 Internal Antenna

${ }^{* *}$ Position from first 3D fix of the receiver

MARKER NAME

$3967128.3067-4389048.4657-2377237.2712$

MARKER NUMBER

OBSERVER / AGENCY

REC\# / TYPE / VERS

ANT\# / TYPE

COMMENT

$\begin{array}{llll}0.0000 & 0.0000 & 0.0000 & \text { ANTENNA: DELTA H/E/N }\end{array}$

10 WAVELENGTH FACT L1/2

2 C1 L1 \# / TYPES OF OBSERV

$\begin{array}{llllllll}2007 & 11 & 1 & 19 & 10 & 48.004227 & \text { GPS } & \text { TIME OF FIRST OBS }\end{array}$

1 INTERVAL

END OF HEADER

071101191048.00422740 8G 4G11G13G16G20G23G25G27

$24488176.5217 \quad 6031903.1527$

$25809723.2277 \quad 6731344.8967$

23146926.85796290963 .1079

$25049359.2398 \quad 6595422.6308$

22000085.58496769934 .9659

$22994948.6419 \quad 6546420.2759$

$21878259.7079 \quad 6316189.9279$

22687294.22996016713 .8629

Exemplo do arquivo Rinex gerado pelo programa gar2rnx.exe

depois das alterações:

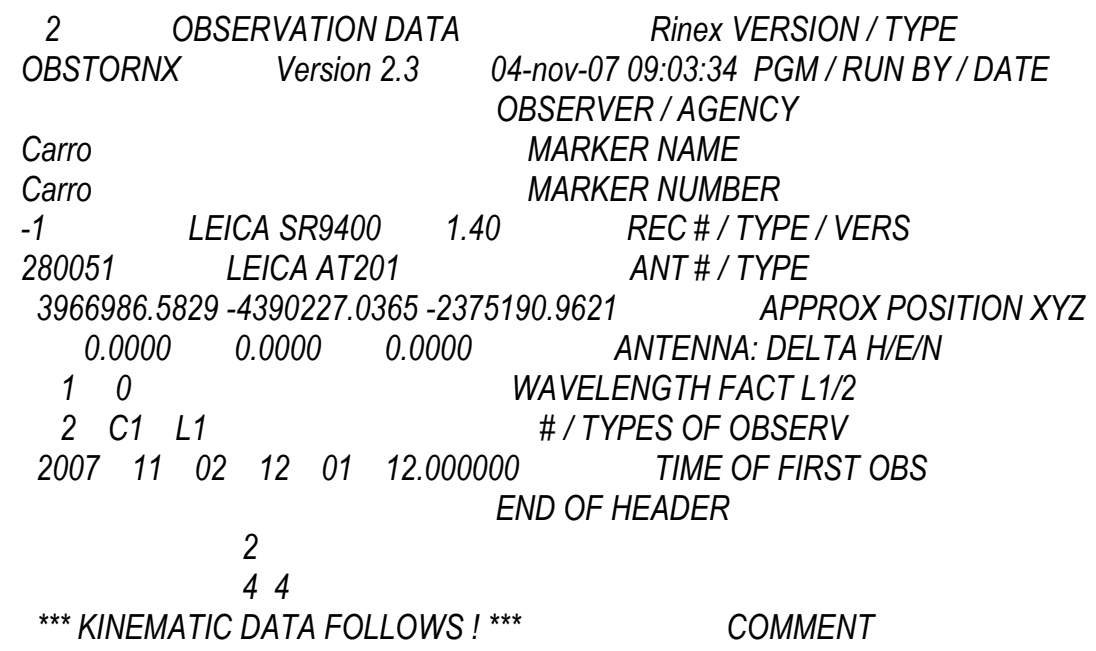

071102120112.05127300 9G 1G 3G14G16G18G19G21G22G31

37644275.465732687399 .6177

36453353.353973031750 .6549

36173476.950973049135 .1099

38813009.677984776547 .0059

38713359.087786627641 .2287

38362257.357868551001 .9528

41084100.177738247862 .5467 
Nesse novo arquivo, os dados provenientes do GPS fixo receberam o nome de STTN e os dados provenientes do GPS em movimento foram chamados de Carro. A figura 3.3.5 a seguir ilustra os dados inseridos no programa. É possível ver o tempo de coleta em comum, sendo em vermelho o tempo de coleta da base fixa e em verde o tempo que o veículo circulou com o GPS ligado.

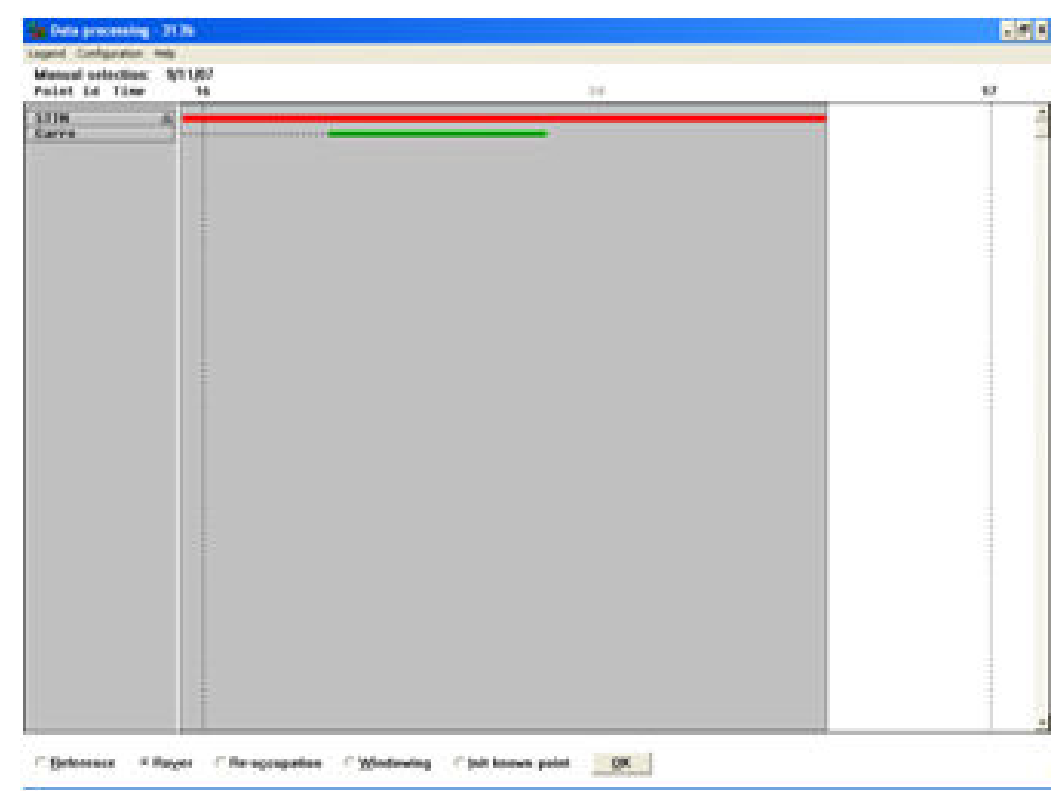

Figura 3.3.5 - Programa SKI 2.3 com os dados inseridos

Note que o domínio, variável tempo, do GPS fixo é bem maior do que o do GPS móvel. Isso ocorre porque a coleta do primeiro era iniciada antes do inicio da trajetória e desligado depois do seu término. Obviamente, apenas os dados do período de tempo comum foram utilizados.

No processamento desses dados, foi usada a opção de se processar por código. Embora essa opção não tenha a mesma precisão do processamento por fase, essa escolha foi feita, pois, atende às necessidades de precisão do trabalho em desenvolvimento e se ganha tempo considerável, pois no processamento por fase é necessário esperar um tempo estático para resolver a ambiguidade.

A figura 3.3.6 mostra a variação da latitude $(X)$, da longitude $(Y)$ e da altura $(Z)$ no tempo, demonstrando que os dados estão dentro de uma faixa aceitável de variação, com precisão submétrica na maior parte do tempo. Houve momentos de variações maiores, que serão corrigidas manualmente, a posteriori. Em geral, as variações foram pequenas, e podem ser desconsideradas, pois se trata 
de um veículo em movimento. A coordenada $Z$ foi desconsiderada por apresentar desvios muito grandes e, no seu lugar, foram utilizadas as cotas nominais da planta oficial da cidade.

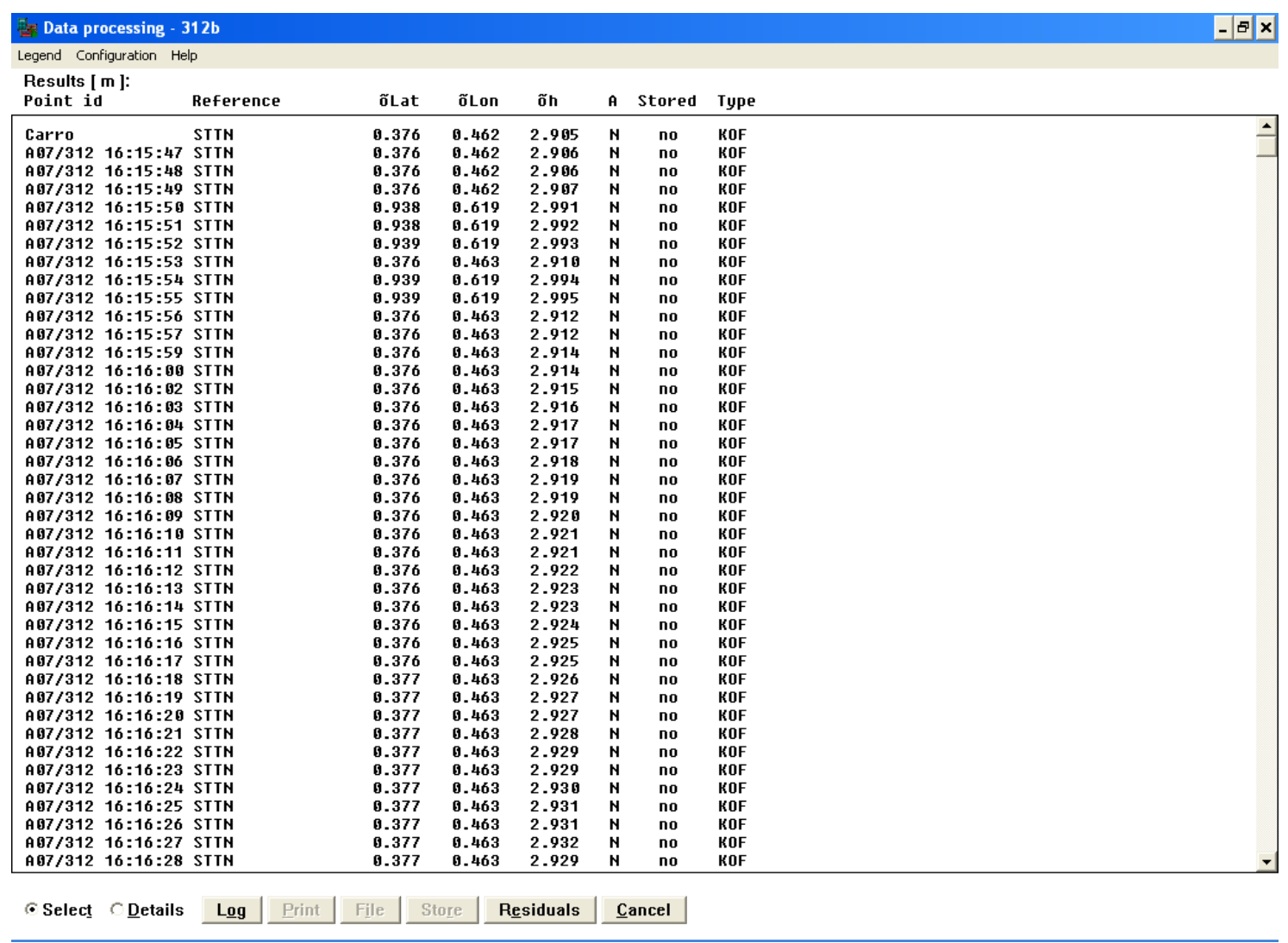

Figura 3.3.6 - Resultado do processamento do programa SKI 2.3

Para que os resultados obtidos pudessem ser utilizados de forma mais conveniente nos procedimentos que se seguiram, eles foram exportados para arquivos utilizáveis em programas de banco de dados. O programa escolhido e usado foi o Excel, do pacote Office.

A figura a 3.3.7 demonstra a forma de exportação dos dados para um formato compatível com o Excel. 


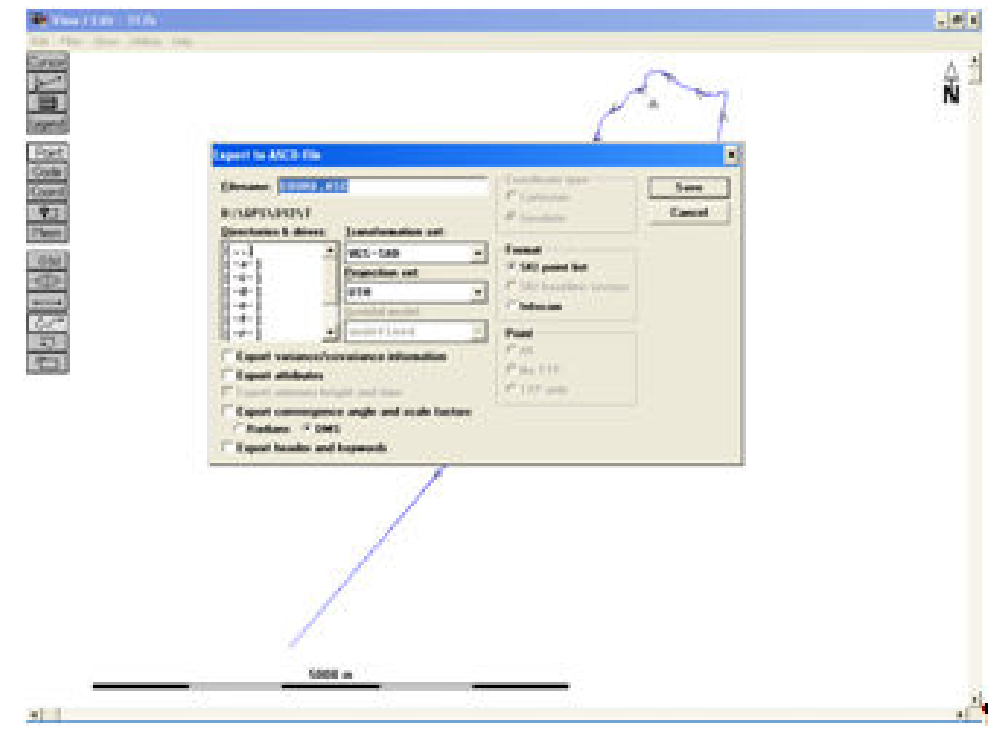

Figura 3.3.7 - Programa SKI 2.3 exportando para texto resultado do processamento

No Excel, os dados foram inseridos de modo a ter colunas de Latitude, Longitude, altitude e tempo em segundos.

A figura 3.3.8 mostra como ficou os dados do processamento GPS inseridos na planilha Excel.

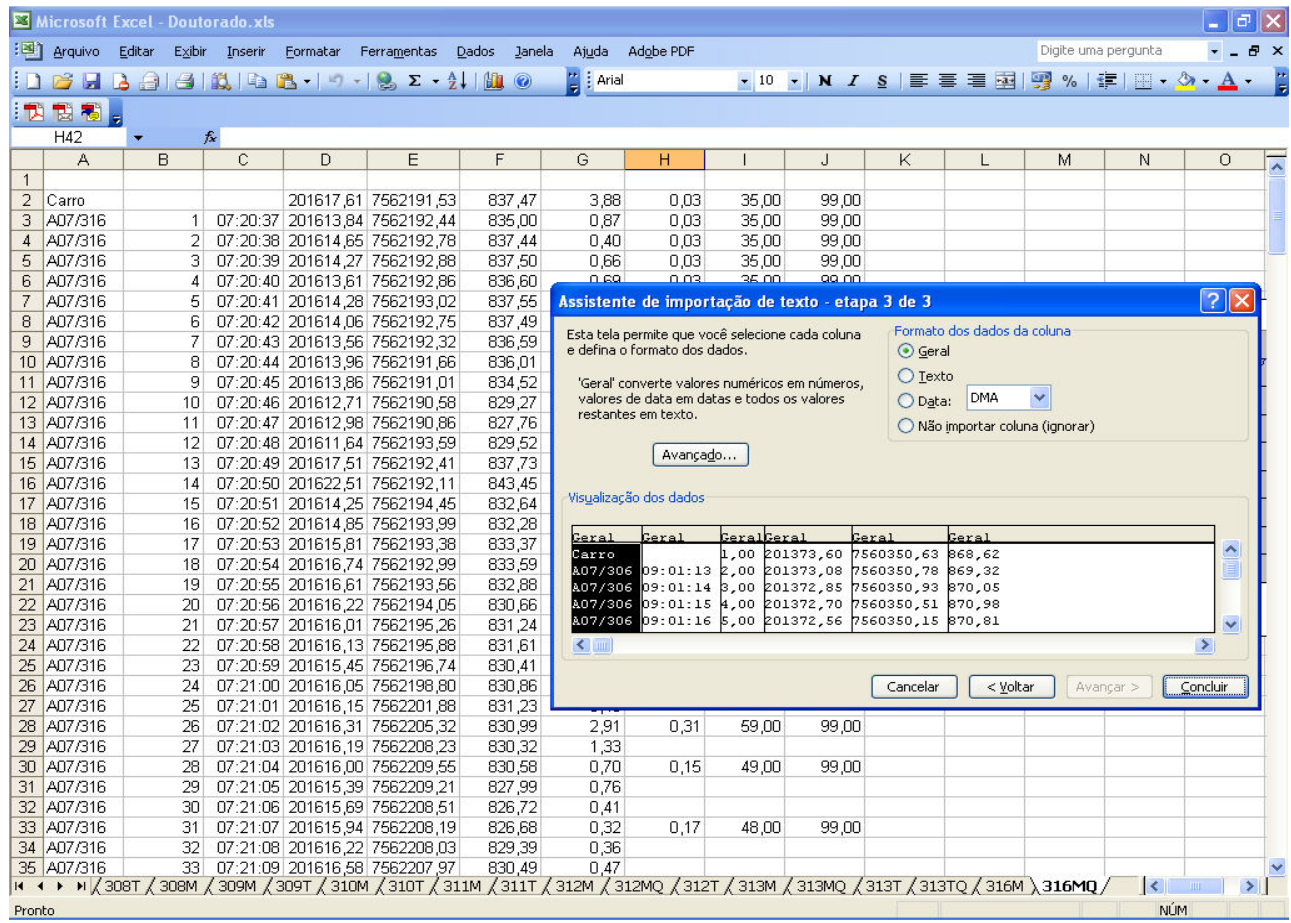

Figura 3.3.8 - Programa Excel importando os dados obtidos pelo GPS 
Com esses dados de posição, segundo a segundo, foi possível calcular a localização, a velocidade, a aceleração e a rampa em que o veículo percorreu as trajetórias previamente escolhidas ao longo do tempo.

A partir do mesmo programa $\mathrm{SKI}$, os dados também foram exportados para um programa de edição de dados vetoriais e de imagem. $O$ programa escolhido para esse tipo de tratamento dos dados foi o AutoCAD. Utilizase este programa na pesquisa para visualizar os dados GPS e corrigir os desvios, além de gerar uma imagem do caminho percorrido pelo veículo em estudo. A figura 3.3.9 demonstra os dados gerados no Ski e que foram exportados ao AutoCAD. Em azul, o caminho percorrido pelo veículo durante os ensaios.

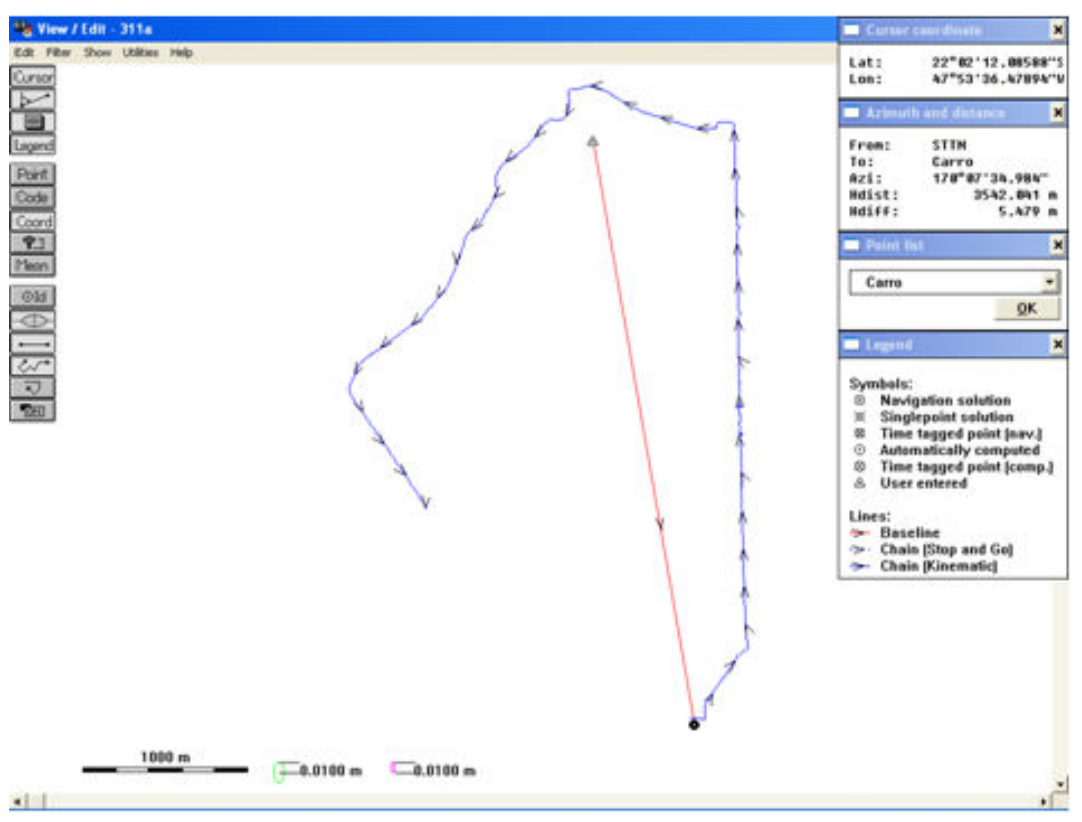

Figura 3.3.9 - Programa SKI 2.3 exportando para formato dxf resultado do processamento GPS

A figura 3.3.10 ilustra os dados sendo importados para o AutoCAD. Esse programa suporta o formato dxf, podendo importá-lo como pode ser visto na figura a seguir. 


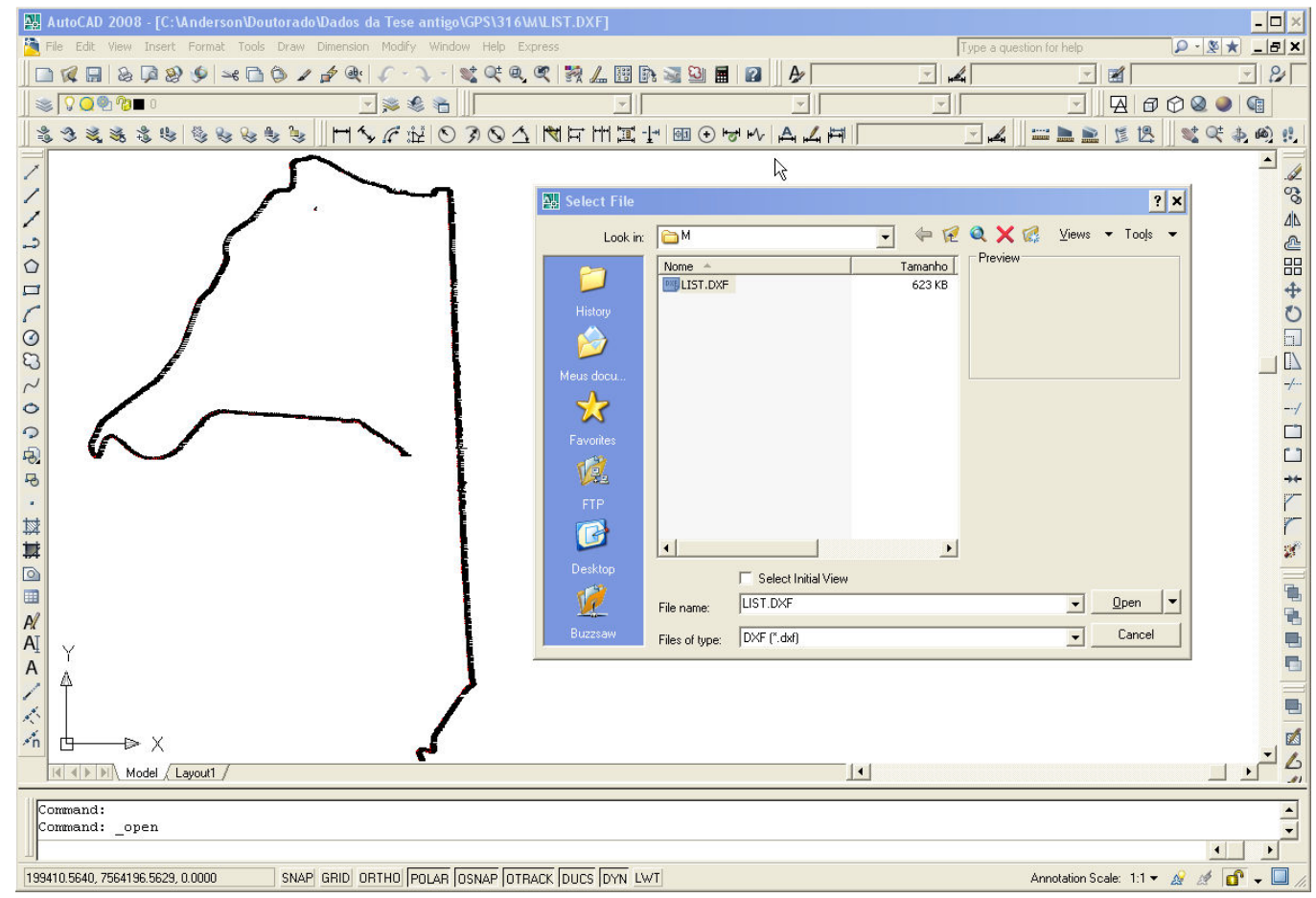

Figura 3.3.10 - Tela do programa AutoCAD importando arquivo dxf.

A figura 3.3.11 ilustra o mapa da cidade vetorizado e o caminho percorrido pelo veículo durante o ensaio (linha amarela). Para cada ensaio era gerada uma figura como essa, para facilitar o entendimento dos dados.

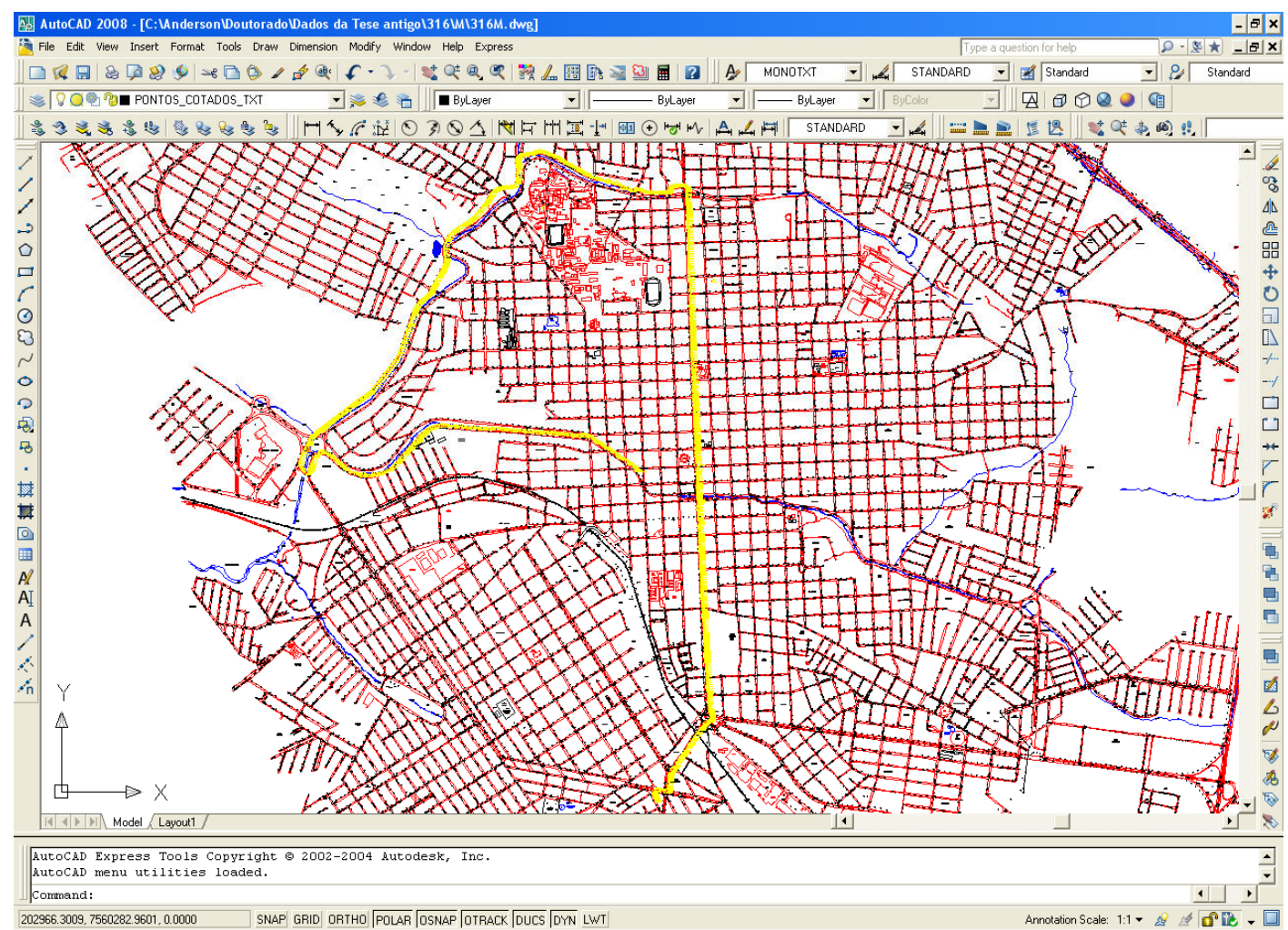

Figura 3.3.11 - Tela do programa AutoCAD com mapa e caminho percorrido durante o ensaio. 
A figura 3.3.12 apresenta a tela do programa SoftGas, do analisador de gás, de onde são extraídos os dados em estudo: $\mathrm{CO}, \mathrm{HC}$ e temperatura do motor, com relação ao tempo.

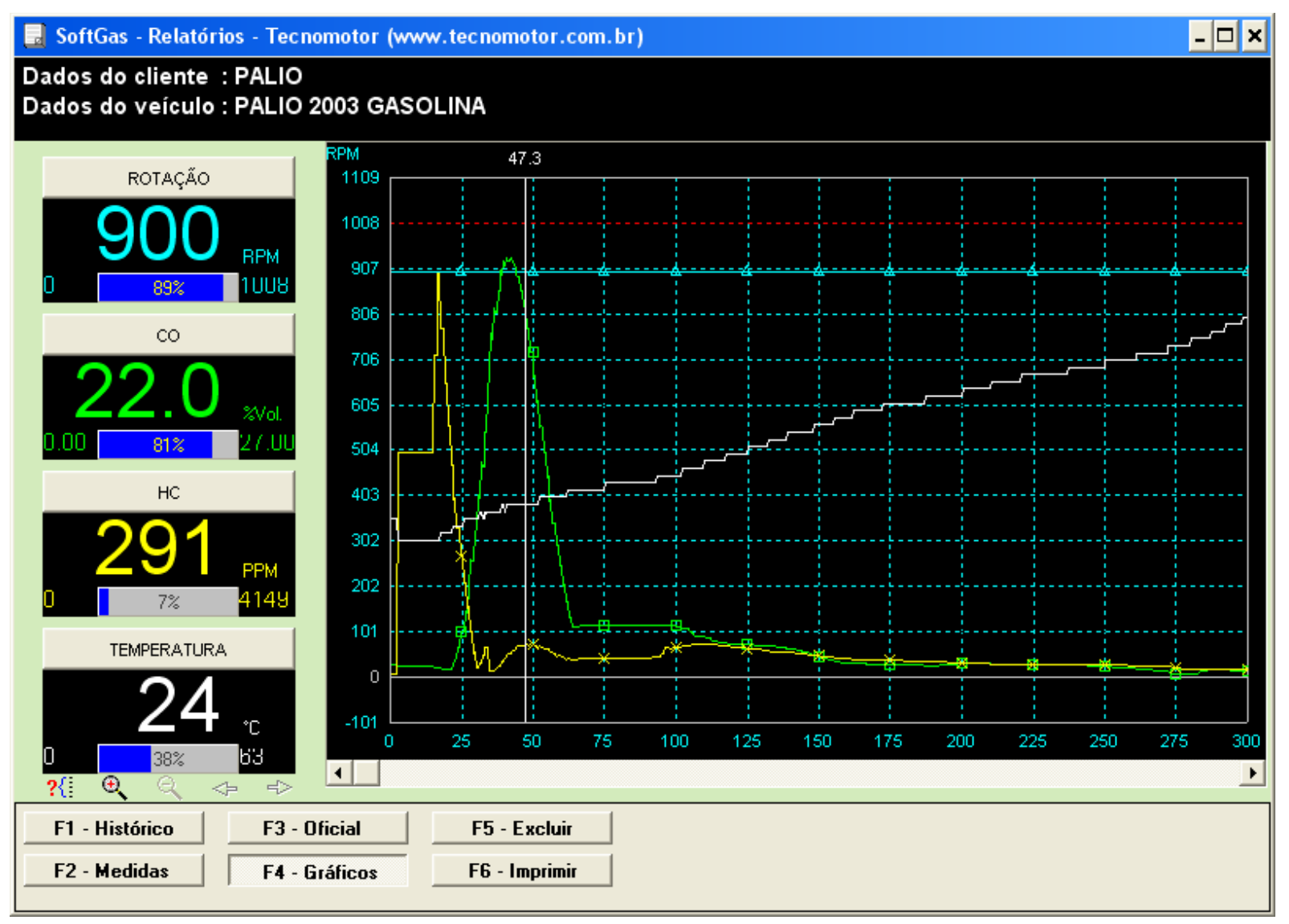

Figura 3.3.12 - Tela do programa SoftGas com gráfico da emissão de gases gerado

O analisador de gases não permite que os dados armazenados sejam exportados diretamente para um formato compatível com o Excel. Assim, os dados do analisador de gás deveriam ser transferidos individualmente, segundo a segundo diretamente no Excel, sendo as leituras feitas diretamente nos gráficos gerados pelo programa da Tecnomotor. Posteriormente, tendo em vista a dificuldade de se passarem todos os dados manualmente utilizou-se um programa capaz de transferir os dados no formato proprietário do software do analisador de gás diretamente para um documento texto, cujos dados eram transferidos para o Excel, em seguida. Os dados relativos a consumo instantâneo foram abertos no Excel e depois copiados e colados na planilha com os dados gerais da pesquisa. 
No final, para cada ensaio, foi gerada uma planilha com o seguinte formato no Excel. A figura 3.3.13 ilustra como a tabela com os dados inseridos ficou.

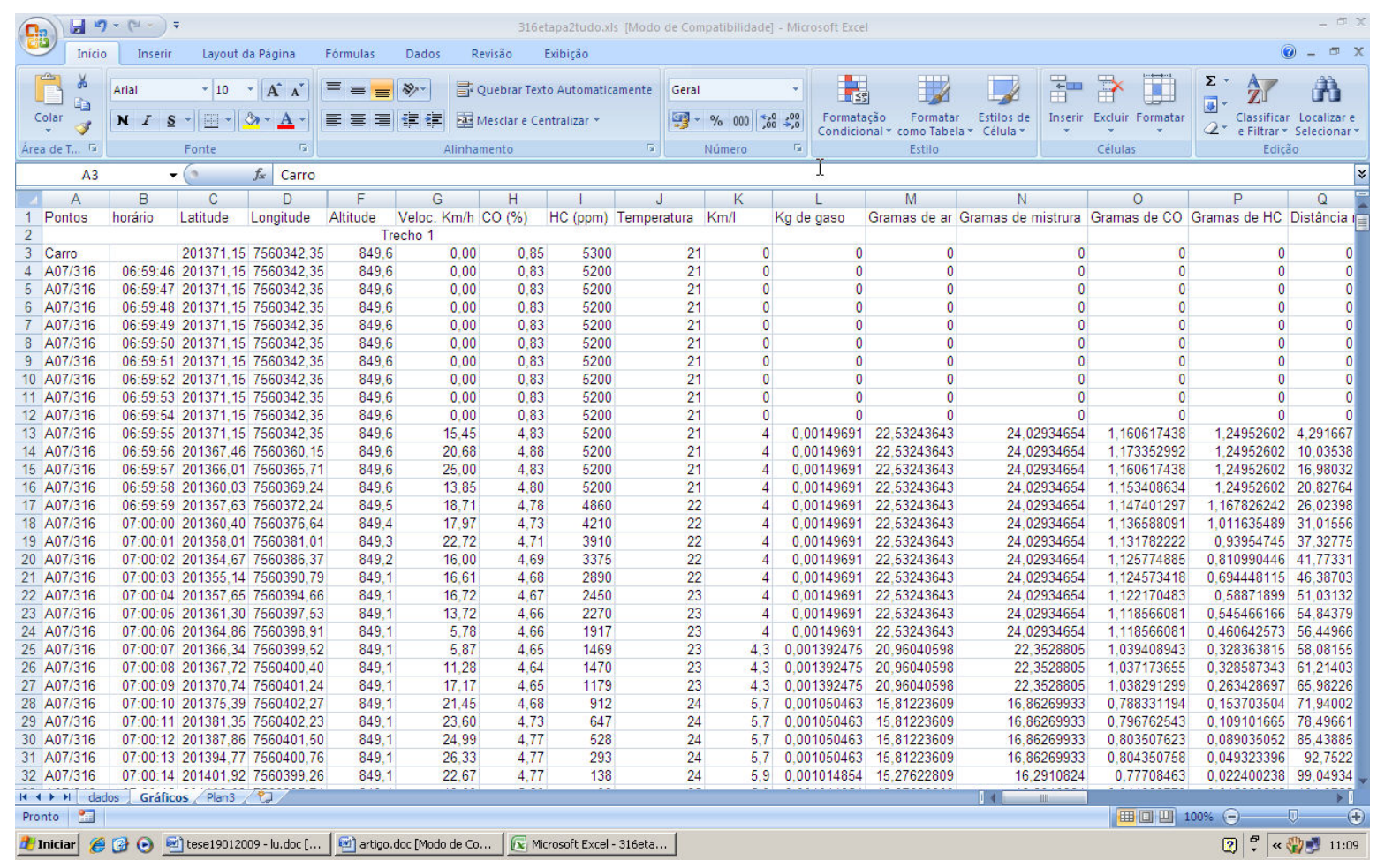

Figura 3.3.13 - Tela do Excel com todos os dados de campo

\subsection{Filtro dos dados}

Todos os dados referentes ao posicionamento do veículo, coletados via GPS, foram lançados no AutoCAD e numa planilha Excel. Num processo de conferência dos dados, a partir do traçado desenhado pelos pontos gerados pelo GPS, que foram inseridos num mapa vetorizado da cidade na escala 1:2000, verificou-se que, em alguns pontos, a trajetória desenvolvida pelo veículo não estava compatível com o traçado das ruas, quer dizer que esses pontos excederam os limites de tolerância submétrica, o que é comum acontecer com esses equipamentos, visto que o GPS Garmin map12 não é muito estável na coleta de dados gerando erros muito grosseiros. Esses desvios foram corrigidos manualmente, colocando-se os pontos destoantes no alinhamento adequado, de forma interpolada com os pontos considerados corretos. 
Por outro lado, esses mesmos saltos também geraram distorções no cálculo da velocidade. Quando foi verificada aceleração ou desaceleração muito brusca no tempo (exemplo: $20 \mathrm{~km} / \mathrm{h}$ em um segundo, $60 \mathrm{~km} / \mathrm{h}$ no segundo seguinte, e $25 \mathrm{~km} / \mathrm{h}$ no próximo), os dados foram corrigidos de modo a se manter a linearidade do comportamento do veículo, conforme verificada empiricamente.

De um total de 50 ensaios, em 4 deles, muitos pontos coletados via GPS estavam fora da tolerância definida, o que inviabilizava sua correção manual. Assim, todos os 4 ensaios foram descartados integralmente.

Também foram descartados dois ensaios em que o Termopar (equipamento responsável por mensurar a temperatura do motor), durante a execução dos ensaios de uma manhã (um frio e um quente), não funcionou e precisou ser trocado na empresa que colaborou com a pesquisa, emprestando 0 equipamento. 


\section{RESULTADOS E CONSIDERAÇÕES}

Os dados brutos, conforme coletados, não têm significância absoluta e precisam, portanto, de organização para que sejam analisados adequadamente. Assim, esses dados foram transformados de modo a se obterem formatos adequados para estudos.

Com base na comparação das amostras obtidas, concluiu-se que selecionar os dados levantados conforme as variáveis de tempo ou de espaço são inviáveis. Analisem-se, por exemplo, os dias 312 e 313 GPS, no período da manhã. No dia 312, o veículo passou na coordenada 210634 E, 7561802 N (cruzamento da Avenida São Carlos com a Rua Santa Cruz), após 3 minutos e 1 segundo do início do ensaio, com velocidade de $35,4 \mathrm{~km} / \mathrm{h}$, emitindo $0,21 \mathrm{~g}$ de $\mathrm{CO}$ e 177 ppm de HC. No dia 313, o veículo passou na mesma coordenada após 3 minutos e 55 segundos do início do ensaio, com velocidade zero $\mathrm{km} / \mathrm{h}$ até o tempo 4 minutos e 17 segundos, quando o veículo volta a se deslocar. Uma análise por média nesta coordenada ou nesse tempo geraria resultados pouco significativos.

Portanto, tendo em vista que, em cada ensaio, por razões variadas (fluxo de trânsito, semáforos, ultrapassagens), o veículo estava em coordenadas diversas no tempo, com condições de velocidade, aceleração, consumo etc. diferenciadas, analisar a emissão de gases tomando por base a divisão temporal impossibilitaria a comparação dos dados obtidos entre os vários ensaios. Essa comparação também não é possível se se tomar a variável espaço, visto que as referidas condições de velocidade, aceleração, consumo também são diferenciadas em cada ensaio em uma mesma coordenada.

Assim, em razão da inconveniência da medição por tempo ou por coordenada específica no espaço, foi dada preferência, primeiramente, por se analisarem os dados obtidos em trechos com características similares, portanto mais homogêneos sob certos aspectos. Essa análise (chamada Etapa 1), entretanto, pode esconder certos detalhes que são revelados em uma análise mais específica. Portanto, também foi feita uma análise específica, a partir de gráficos, de um único ensaio tomado como prototípico, em que os dados analisados serão estudados tomando-se por base as variáveis de tempo e de espaço. A esta análise chamou-se 
Etapa 2. A análise dos dados com base nesses dois procedimentos é capaz de ressaltar a relevância de cada informação de modo distinto e significativo.

$\mathrm{Na}$ Etapa 1, cada percurso foi dividido em cinco trechos, com características específicas e convenientes para a pesquisa em andamento. A divisão dos trechos partiu das premissas de que a inclinação da via e a temperatura do motor influenciam diretamente na emissão de poluentes. Outro parâmetro relevante para a fragmentação dos trechos analisados refere-se às condições de tráfego, já que, presumivelmente, trechos em que não há redução de marcha são suscetíveis a menor emissão de poluentes.

O trecho 1 se estende do local onde o veículo pernoitava até o local considerado ideal para se iniciar efetivamente os ensaios.

Para que o teste se iniciasse no eixo representativo do maior fluxo de veículos, o veículo deveria ficar estacionado no início da Avenida São Carlos até que o motor estivesse frio, ou seja, cerca de 8 horas. Desse modo, o veículo utilizado nos testes permaneceria durante vários dias e noites em local pouco conveniente, o que poderia acabar por inviabilizar a pesquisa (caso o veículo fosse furtado, por exemplo). Assim, optou-se por incluir este pequeno trecho inicial nos ensaios, tomando-se os devidos cuidados para que esta inclusão não fosse prejudicial aos testes. Este trecho é considerado de menor interesse para os testes, mas, não deixa de fornecer informações relevantes.

O trecho 2 é em declive médio, ou seja, não é o maior declive dos estudos, mas tem inclinação que favorece o desempenho do motor. O trecho 3 é aclive acentuado, o que reconhecidamente exige mais do motor. $\mathrm{O}$ trecho 4 volta a ser declive, entretanto, aqui o motor já está mais aquecido. $O$ trecho 5 é relativamente plano, mas em declive moderado, com tráfego pouco intenso, permitindo manter velocidade constante e funcionamento do motor em condições de emissão mínima de poluentes (quinta marcha sem grandes acelerações e rotação do motor baixa), portanto, é o trecho que mais se aproxima do ideal, no que se refere à emissão de gases.

Para os trechos 1 e 2, foi ensaiada a emissão apenas com o motor frio. Para os trechos 3 e 4, há ensaios para o motor frio e quente. Para o trecho 5 , os ensaios referem-se apenas ao motor quente. Cada trecho está minuciosamente descrito nas análises a seguir. 
Esta Etapa 1 trata, portanto, de, a partir dos dados coletados em cada trecho, com o motor frio e quente, obter a média de cada trecho e comparála com parâmetros já existentes na literatura. A comparação fundamental se refere à emissão de $\mathrm{CO}$ e de $\mathrm{HC}$ em $\mathrm{g} / \mathrm{km}$, cotejando-se os parâmetros já existentes, conforme discutidos no item 4.2.1 e os valores obtidos na medição real, conforme descrita no capítulo anterior.

A Etapa 2 consiste em analisar o comportamento da emissão dos gases em um dos ensaios, tomado como padrão, dada a inconveniência de se analisar minuciosamente cada um dos ensaios obtidos. Serão apresentados, portanto, todos os gráficos obtidos em cada segundo da medição, com a análise meticulosa de cada um dos parâmetros relevantes para este trabalho.

É importante ressaltar que durante a execução de todos os ensaios o veículo sempre funcionou com a marcha engrenada.

\subsection{Etapa 1}

O Trecho 1 tem 730 metros e se inicia na Rua Elias Arsênio, seguindo para a Rua Theodureto de Camargo. Daí vai até o balão que cruza com a Avenida Pádua Sales, por onde continua até a rotatória que cruza com a Rua João Lourenço Rodrigues, seguindo por essa rua até a Praça Itália.

A figura 4.1.1 ilustra a Rua João Lourenço Rodrigues sentido Praça Itália em um período sem veículos circulando, tirada de manhã permitindo visualizar sua inclinação. 


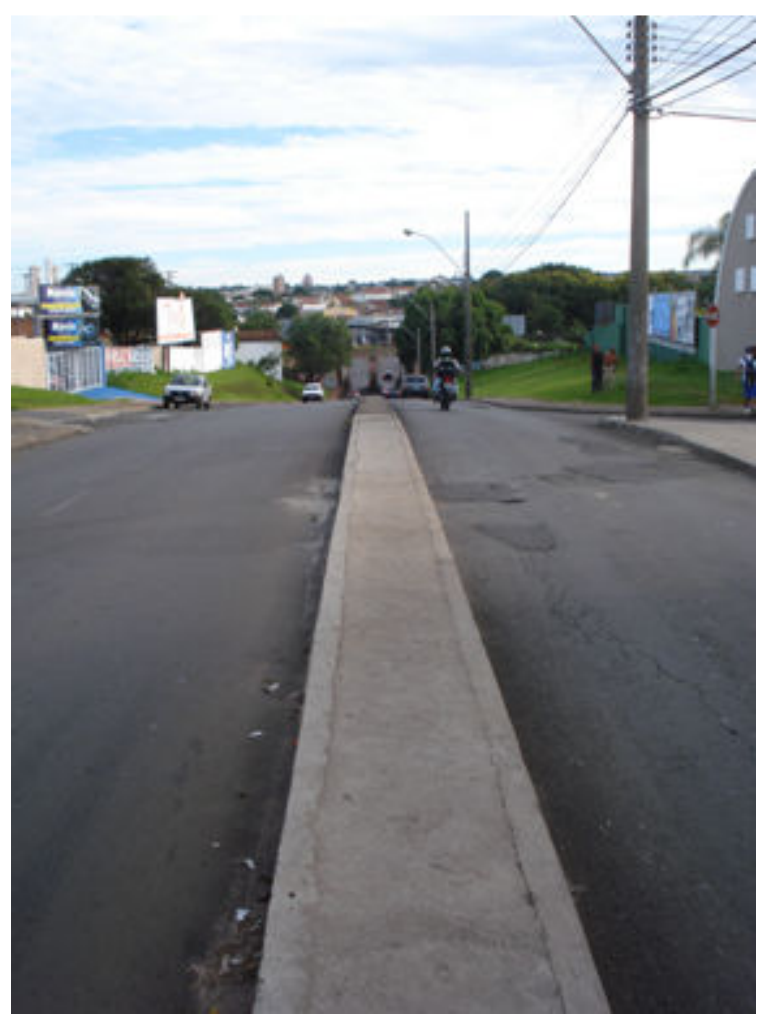

Figura 4.1.1 - Foto ilustrativa do Trecho 1 - Rua João Lourenço Rodrigues

O trânsito normalmente neste trecho é moderado, formando pouco engarrafamento, agravado apenas nos períodos de entrada e saída de aula do colégio Jesuíno de Arruda. A maior parte do trajeto é em declive, com apenas uma região de aclive, no fim do percurso. Nesse trecho não há semáforos, mas existem redutores de velocidade e muitas placas de parada obrigatória, o que reduz a velocidade média. Em geral, há movimentação de pessoas e algumas casas comerciais. A poluição gerada nesse trecho provavelmente tem boa dispersão, pois não possui grande adensamento de edificações.

A figura 4.1.2 mostra uma parte do mapa da cidade com o Trecho 1 no centro do contorno em destaque. Os pontos vermelhos e letras azuis representam os dados coletados com o GPS no ensaio 316 período manhã motor frio, e descrevem a trajetória do veículo. O texto azul refere-se ao horário GPS da coleta, (decrescido em 1 hora no caso) e os pontos vermelhos descrevem as coordenadas do veículo em cada instante. $\mathrm{O}$ acúmulo de pontos em determinadas regiões significa baixa velocidade ou não movimentação do veículo. Em verde, uma aproximação de como os pontos ficava na via, visto que em escala normal, não é possível fazer a visualização de detalhes. 


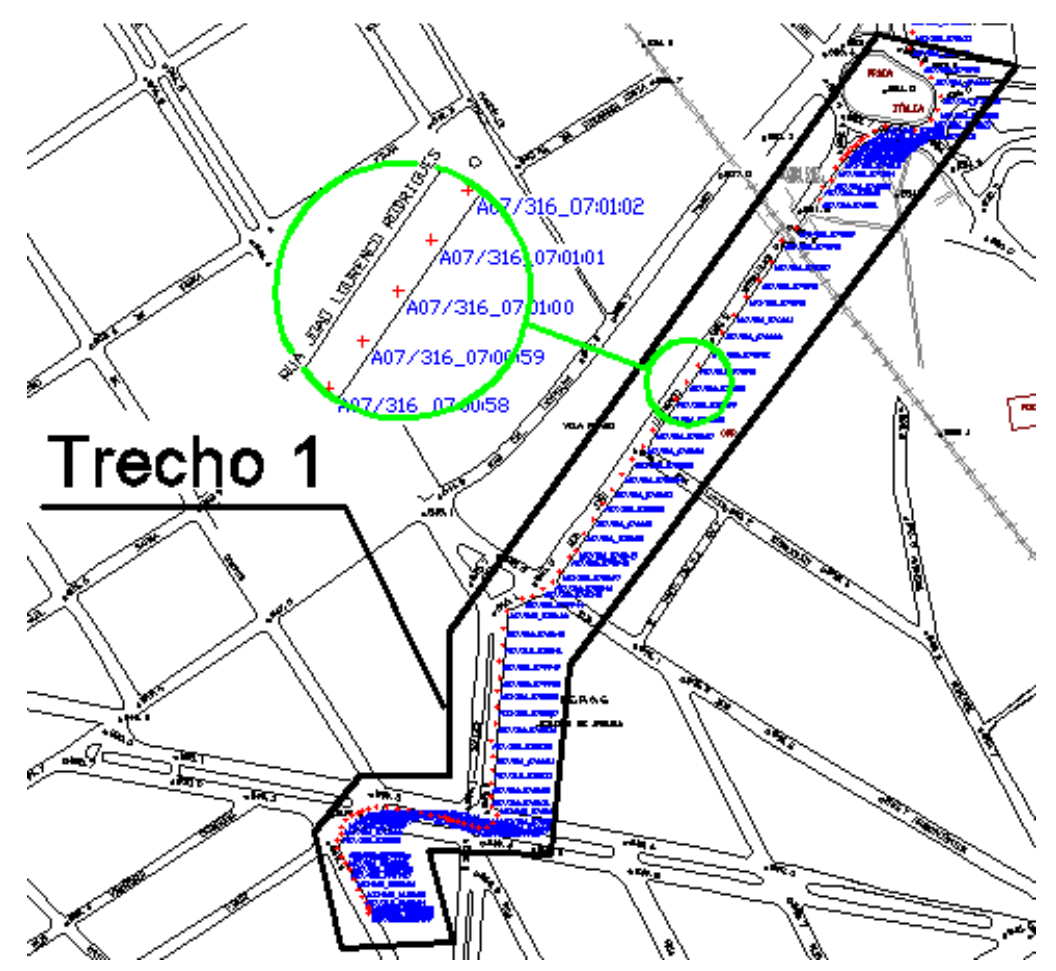

Figura 4.1.2 - Mapa ilustrativo do percurso do veículo no ensaio 316MF no Trecho 1

A figura 4.1.2 é representativa de um dos ensaios, podendo ocorrer variação na concentração de pontos de acordo com a condição de trânsito no momento da coleta de dados

A tabela 4.1.1 mostra as médias das variáveis relevantes obtidas no Trecho 1, que foram feitas só com motor frio.

Tabela 4.1.1 - Resultados de campo obtidos com motor frio: médias totais dos ensaios no Trecho 1

\begin{tabular}{|r|c|}
\hline Velocidade média $(\mathrm{km} / \mathrm{h})$ & 23,2 \\
\hline Consumo médio $(\mathrm{km} / \mathrm{l})$ & 6,9 \\
\hline Inclinação média no trecho $(\%)$ & $-2,2$ \\
\hline Massa de combustível $(\mathrm{g})$ & 105,0 \\
\hline Porcentagem média de emissão de CO (\%) & 4,5 \\
\hline Temperatura média $\left({ }^{\circ} \mathrm{C}\right)$ na vareta de óleo de motor & 29 \\
\hline Emissão de CO no trecho $(\mathrm{g})$ & 44,0 \\
\hline Emissão de HC no trecho $(\mathrm{g})$ & 9,7 \\
\hline Emissão de CO médio no trecho $(\mathbf{g} / \mathbf{k m})$ & 60,3 \\
\hline Média de emissão de HC (g/km) & 13,3 \\
\hline \hline Emissão de CO calculado pelo modelo da ANTP $^{6}$ & 27,8 \\
\hline \hline Emissão de HC calculado pelo modelo da ANTP & 2,4 \\
\hline
\end{tabular}

${ }^{6}$ Conforme equação 2.8.2 (CO $\left.(\mathrm{g} / \mathrm{km})=-4,51+727 / \mathrm{V}+1,34 \mathrm{E}-3^{*} \mathrm{~V}^{2}\right)$.

${ }^{7}$ Conforme equação 2.8.1 ( $\left.\mathrm{HC}(\mathrm{g} / \mathrm{km})=-0,28+62,48 / \mathrm{V}\right)$. 
Neste trecho, é possível notar uma emissão mensurada de CO muito maior $(60,3 \mathrm{~g} / \mathrm{km})$ que aquela apontada, por exemplo, pelo modelo da ANTP $(27,8 \mathrm{~g} / \mathrm{km})$, aqui adotado como prototípico. Esse modelo se fundamenta na equação 2.8.2, descrita e explicitada no capítulo 2 .

Essa diferença ocorre justamente pelo fato de o modelo adotado pela ANTP desconsiderar invariavelmente questões cruciais para a emissão de gases poluentes, como a temperatura do motor, a declividade média e a diversidade do trânsito no trecho. Em geral, as equações dos modelos para a emissão de gases baseiam-se apenas na velocidade média, o que gera grandes distorções em cidades pequenas e médias, onde predominam pequenos deslocamentos com o motor ainda frio por consequência. Nesse trecho, mesmo havendo predominância de declive, pelo fato de o motor estar ainda frio, os dados de emissão de CO foi bem elevado.

Com relação ao $\mathrm{HC}$, calculado também de acordo com a equação 2.8.1, descrita no capítulo 2 , a distorção se mostra ainda maior. $O$ ensaio aponta um valor quase 6 vezes superior àquele calculado conforme o modelo da ANTP.

O Trecho 2 tem 1230 metros e se inicia no fim da Praça Itália, onde finaliza o Trecho 1, seguindo pela Avenida São Carlos, até o cruzamento com a Rua Geminiano Costa.

A figura 4.1.3 ilustra a Avenida São Carlos, sentido norte em um período com poucos veículos circulando de modo a permitir visualizar sua inclinação. 


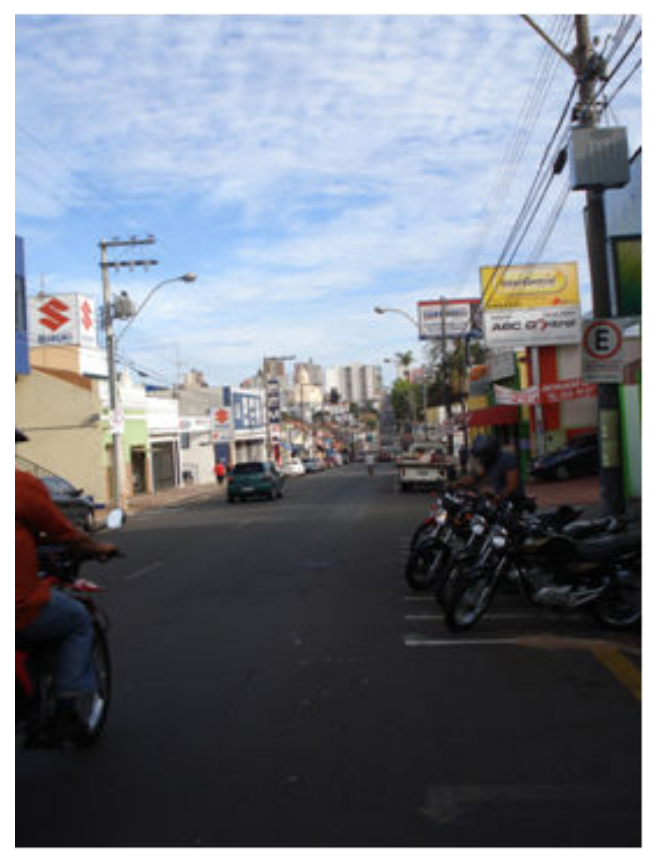

Figura 4.1.3 - Foto ilustrativa do Trecho 2 - Avenida São Carlos

O trânsito neste trecho depende do dia e horário, podendo variar de moderado com fluidez até quase parado, formando engarrafamento. Neste trecho só há declive. Os semáforos nem sempre estão sincronizados e não formam ondas verdes, o que, associado ao desrespeito pelas normas de trânsito por muitos motoristas, reduz a velocidade média. Há grande movimentação de pessoas e muitas casas comerciais. A poluição gerada neste trecho provavelmente não tem boa dispersão, pois possui grande adensamento de edificações.

A figura 4.1.4 mostra uma parte do mapa da cidade com um contorno em destaque sobre o Trecho 2 . Em verde, uma aproximação de como os pontos ficava na via, visto que em escala normal, não é possível fazer a visualização de detalhes. 


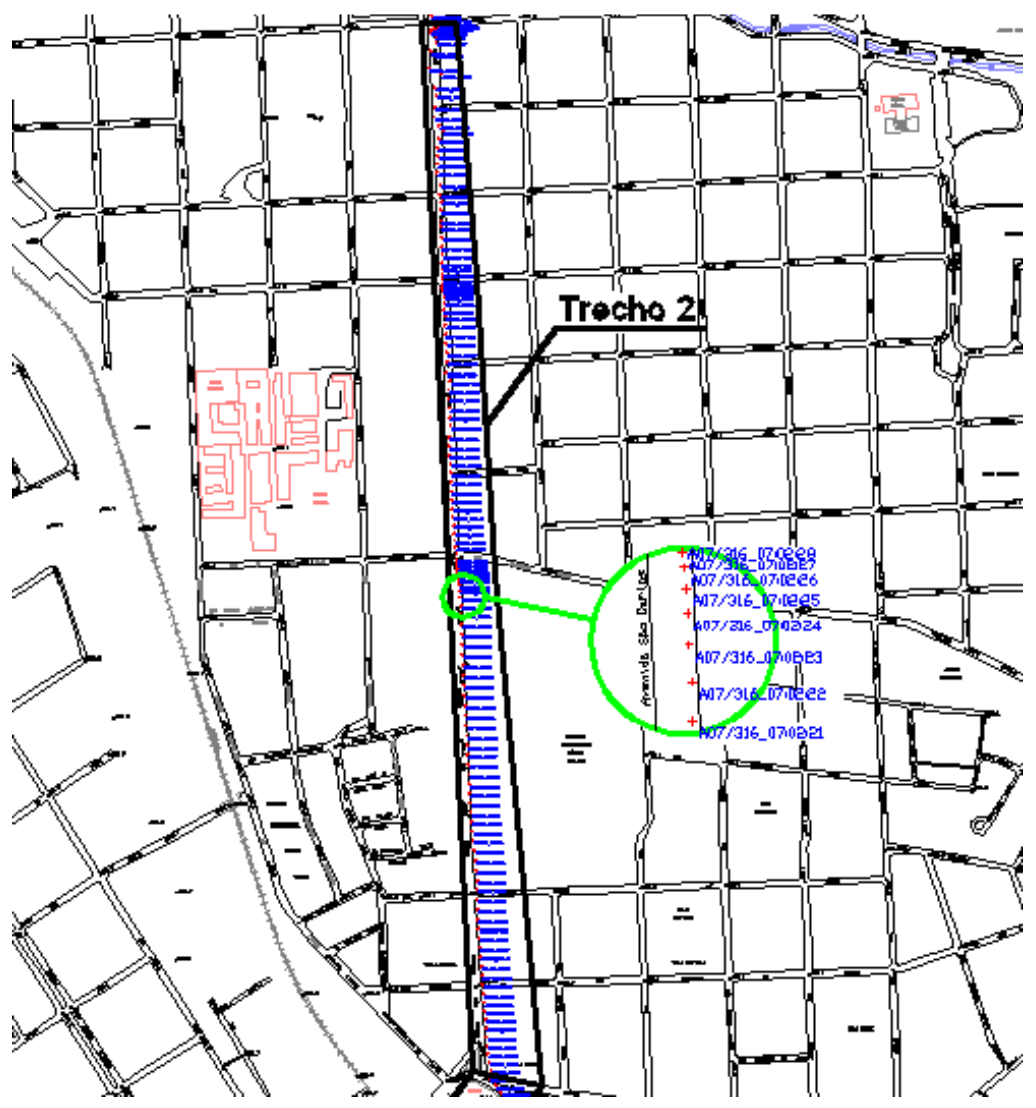

Figura 4.1.4 - Mapa ilustrativo do percurso do veículo no ensaio 316MF no Trecho 2

A tabela 4.1.2 mostra a média das variáveis relevantes obtidas no Trecho 2, com motor frio.

Tabela 4.1.2 - Resultados de campo obtidos com motor frio: médias totais dos ensaios no Trecho 2

\begin{tabular}{|c|c|}
\hline Velocidade média $(\mathrm{km} / \mathrm{h})$ & 24,3 \\
\hline Consumo médio $(\mathrm{km} / \mathrm{l})$ & 8,9 \\
\hline Inclinação média no trecho $(\%)$ & $-2,5$ \\
\hline Massa de combustível $(\mathrm{g})$ & 100,0 \\
\hline Porcentagem média de emissão de CO (\%) & 3,1 \\
\hline Temperatura média $\left({ }^{\circ} \mathrm{C}\right)$ na vareta de óleo de motor & 50,0 \\
\hline Emissão de CO no trecho $(\mathrm{g})$ & 61,0 \\
\hline Emissão de HC no trecho (g) & 7,9 \\
\hline Emissão de CO médio no trecho (g/km) & 49,6 \\
\hline Média de emissão de HC (g/km) & 6,4 \\
\hline Emissão de CO calculado pelo modelo da ANTP & 26,2 \\
\hline Emissão de HC calculado pelo modelo da ANTP & 2,3 \\
\hline
\end{tabular}


Neste trecho, a emissão mensurada de $\mathrm{CO}$ continua superior ao modelo da ANTP $(49,6 \mathrm{~g} / \mathrm{km}$ contra 26,2 g/ $\mathrm{km}$ ). Mesmo sendo declive, o motor ainda está frio; assim os dados de emissão de CO continuam bem elevados. Com relação ao $\mathrm{HC}$, a distorção se mostra menor, apontando um valor quase 3 vezes superior àquele calculado no modelo da ANTP.

O Trecho 3 tem 990 metros e se inicia no cruzamento da Rua Geminiano Costa, seguindo pela Avenida São Carlos, até o cruzamento com a Avenida Dr. Carlos Botelho.

A figura 4.1.3 ilustra a Avenida São Carlos, sentido norte em um período com poucos veículos circulando de modo a permitir visualizar sua inclinação.

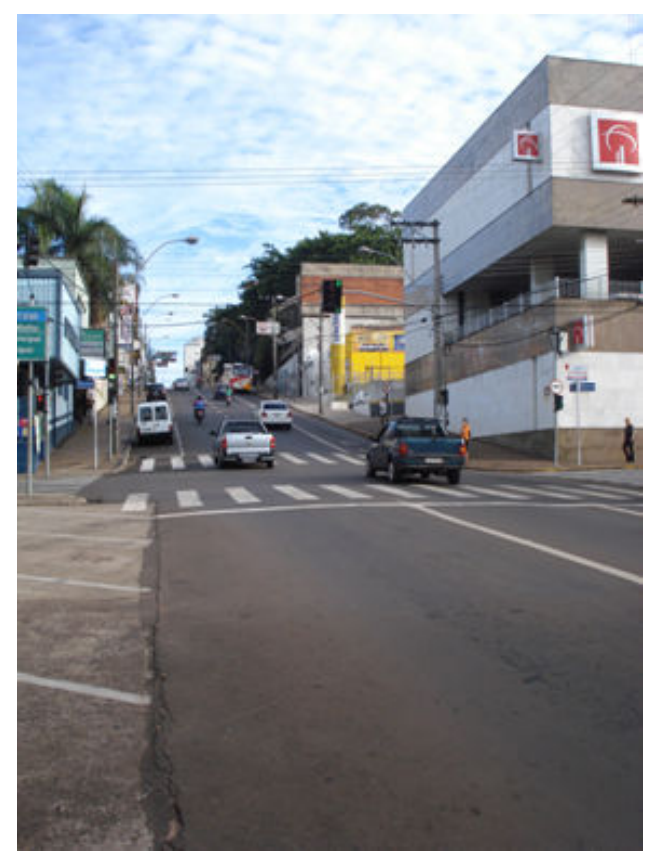

Figura 4.1.5 - Foto ilustrativa do Trecho 3 - Avenida São Carlos

O trânsito neste trecho depende do dia e horário, podendo ser moderado com fluidez e quase parado, formando engarrafamento. Neste trecho só há aclive. Os semáforos nem sempre estão sincronizados e não formam ondas verdes, o que, associado ao desrespeito pelas normas de trânsito por muitos motoristas, reduz a velocidade média. Há grande movimentação de pessoas e muitas casas comerciais. A poluição gerada nesse trecho provavelmente não tem boa dispersão, pois possui grande adensamento de edificações de altura variada. 
A figura 4.1.6 mostra uma parte do mapa da cidade com um contorno em destaque sobre o Trecho 3 . Em verde, uma aproximação de como os pontos ficava na via, visto que em escala normal, não é possível fazer a visualização de detalhes.

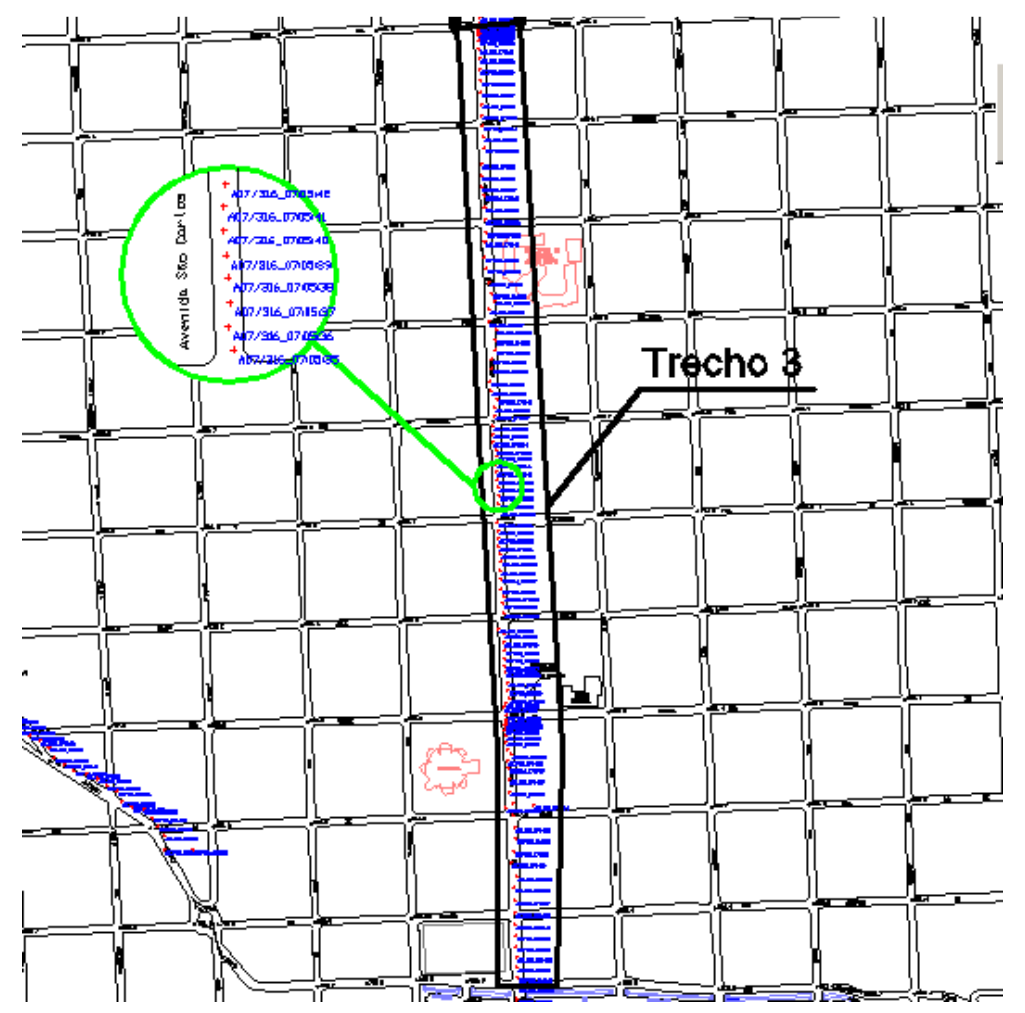

Figura 4.1.6 - Mapa ilustrativo do percurso do veículo no ensaio 316MF no Trecho 3

A tabela 4.1.3 mostra a média das variáveis relevantes obtidas no Trecho 3 com o motor ainda frio. 
Tabela 4.1.3 - Resultados de campo obtidos com motor frio: médias totais dos ensaios no Trecho 3

\begin{tabular}{|r|c|}
\hline Velocidade média $(\mathrm{km} / \mathrm{h})$ & 26,8 \\
\hline Consumo médio $(\mathrm{km} / \mathrm{l})$ & 5,3 \\
\hline Inclinação média no trecho (\%) & $+6,2$ \\
\hline Massa de combustível $(\mathrm{g})$ & 137,8 \\
\hline Porcentagem média de emissão de CO (\%) & 2,4 \\
\hline Temperatura média $\left({ }^{\circ} \mathrm{C}\right)$ na vareta de óleo de motor & 69,0 \\
\hline Emissão de CO no trecho (g) & 51,7 \\
\hline Emissão de HC no trecho (g) & 1,9 \\
\hline Emissão de CO médio no trecho (g/km) & 52,2 \\
\hline Média de emissão de HC (g/km) & 2,0 \\
\hline Emissão de CO calculado pelo modelo da ANTP & 23,3 \\
\hline Emissão de HC calculado pelo modelo da ANTP & 2,03 \\
\hline
\end{tabular}

Com o motor frio e em aclive, como neste trecho, a emissão de $\mathrm{CO}$ ainda é superior àquela adotada no modelo prototípico (52,2 $\mathrm{g} / \mathrm{km}$ contra 23,3 $\mathrm{g} / \mathrm{km}$ ). A medição obtida no ensaio se mostra mais coerente com as informações teóricas, na comparação entre os dados obtidos aqui e no trecho anterior (tabela 5.1.2), visto que em aclive há mais esforço do motor e, portanto, maior emissão de CO. A emissão de gases no modelo ANTP foi menor no aclive $(23,3 \mathrm{~g} / \mathrm{km}$ contra $26,2 \mathrm{~g} / \mathrm{km}$ ) que no declive, pois os dados levam em consideração unicamente a velocidade, que foi maior no trecho em aclive $(26,8 \mathrm{~km} / \mathrm{h})$ que no trecho em declive, em média $(24,3 \mathrm{~km} / \mathrm{h})$.

Tendo em vista que neste trecho o motor está mais aquecido, era de se esperar que a emissão de CO fosse menor. Entretanto, comparando-se os valores obtidos nos trechos 2 e 3 com o motor ainda frio (49,6 g/km contra 52,2 $\mathrm{g} / \mathrm{km}$ ), percebe-se que a emissão foi maior aqui, o que ocorreu em virtude do aclive da via.

A emissão de $\mathrm{HC}$ continua caindo em comparação com o trecho anterior, independentemente da inclinação da via e fica muito próxima do resultado do modelo prototípico, já que o motor está mais aquecido.

A tabela 4.1.4 mostra a média das variáveis relevantes obtidas no Trecho 3 com o motor aquecido. 
Tabela 4.1.4 - Resultados de campo obtidos com motor quente: médias totais dos ensaios no Trecho 3

\begin{tabular}{|c|c|}
\hline Velocidade média $(\mathrm{km} / \mathrm{h})$ & 25,6 \\
\hline Consumo médio $(\mathrm{km} / \mathrm{l})$ & 6,9 \\
\hline Massa de combustível $(\mathrm{g})$ & 103,9 \\
\hline Porcentagem média de emissão de CO $(\%)$ & 1,2 \\
\hline Temperatura média $\left({ }^{\circ} \mathrm{C}\right)$ na vareta de óleo de motor & 101,0 \\
\hline Emissão de CO no trecho $(\mathrm{g})$ & 20,4 \\
\hline Emissão de HC no trecho $(\mathrm{g})$ & 0,6 \\
\hline Emissão de CO médio no trecho $(\mathbf{g} / \mathbf{k m})$ & 20,6 \\
\hline Média de emissão de HC $(\mathbf{g} / \mathbf{k m})$ & 0,6 \\
\hline Emissão de CO calculado pelo modelo da ANTP & 24,52 \\
\hline Emissão de HC calculado pelo modelo da ANTP & 2,1 \\
\hline
\end{tabular}

A emissão de CO no trecho 3 com o motor quente é muito semelhante à do modelo prototípico adotado, mostrando-se um pouco inferior (20,6 $\mathrm{g} / \mathrm{km}$ contra $24,5 \mathrm{~g} / \mathrm{km}$ ). É curioso notar, por outro lado, que a emissão de $\mathrm{HC}$ foi muito menor que a adotada pelo modelo da ANTP $(0,6 \mathrm{~g} / \mathrm{km}$ contra $2,1 \mathrm{~g} / \mathrm{km})$.

Os resultados obtidos no mesmo trecho com o motor aquecido são muito diferentes daqueles obtidos com o motor frio. $O$ motor aquecido emite menos da metade do $\mathrm{CO}$ emitido pelo motor frio $(52,2 \mathrm{~g} / \mathrm{km}$ contra $20,6 \mathrm{~g} / \mathrm{km})$. A emissão de $\mathrm{HC}$ também é menor: $2,0 \mathrm{~g} / \mathrm{km}$ contra $0,6 \mathrm{~g} / \mathrm{km}$.

O Trecho 4 tem 700 metros e se inicia no cruzamento da Avenida Carlos Botelho, seguindo pela Avenida São Carlos, até o cruzamento com a Rua César Ricome.

A figura 4.1.7 ilustra a Avenida São Carlos, sentido norte em um período com poucos veículos circulando de modo a permitir visualizar sua inclinação. 


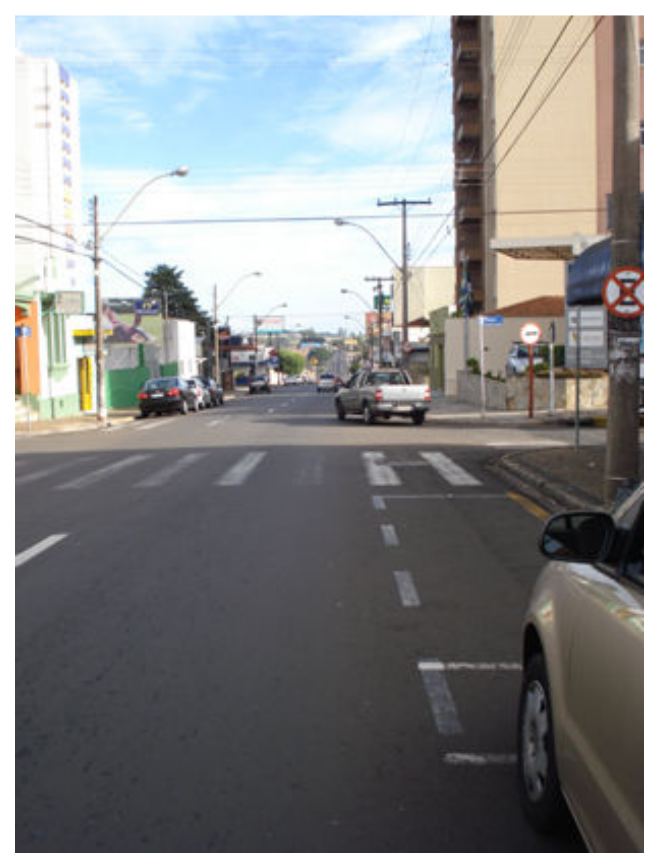

Figura 4.1.7 - Foto ilustrativa do Trecho 4 - Avenida São Carlos

O trânsito neste trecho é mais moderado, com fluidez e raramente com engarrafamentos. Neste trecho só há declive. Poucos semáforos e obstáculos permitem uma velocidade média maior. Há moderada movimentação de pessoas e casas comerciais. A poluição gerada nesse trecho tem moderada dispersão.

A figura 4.1.8 mostra uma parte do mapa da cidade com um contorno em destaque sobre o Trecho 4. Em verde, uma aproximação de como os pontos ficava na via, visto que em escala normal, não é possível fazer a visualização de detalhes. 


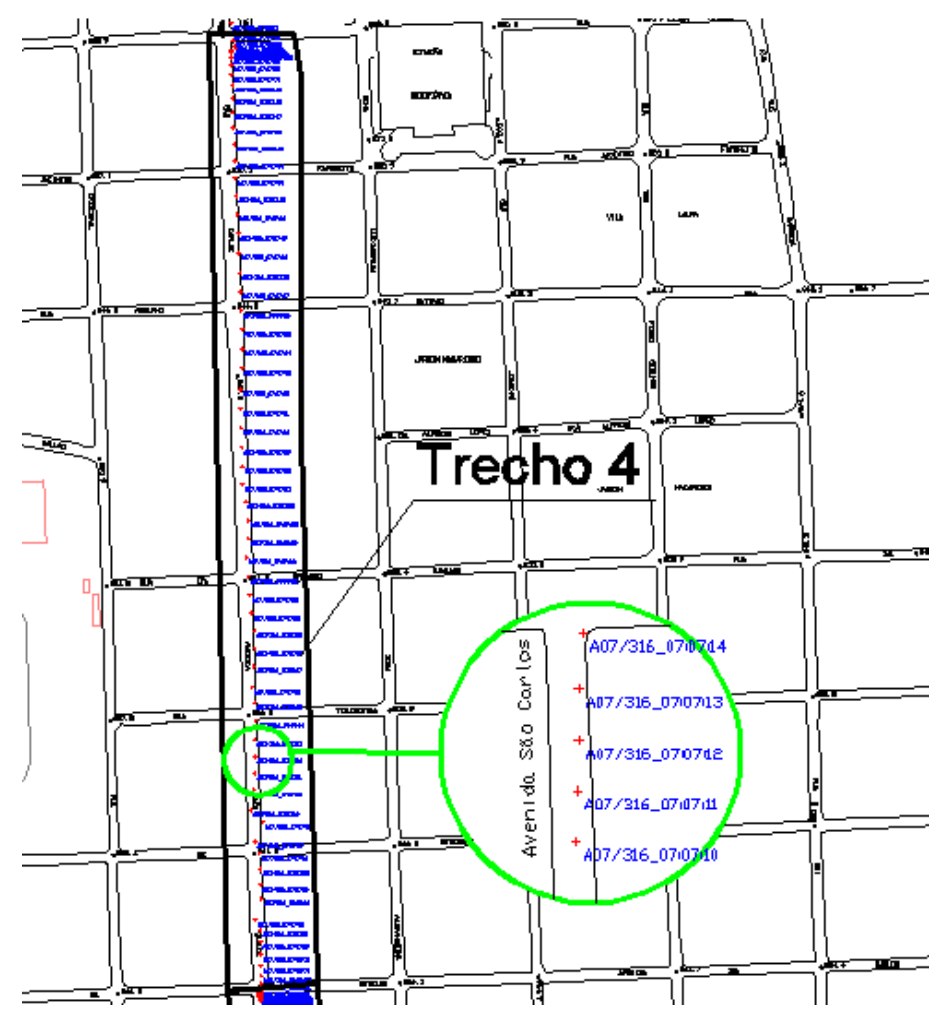

Figura 4.1.8 - Mapa ilustrativo do percurso do veículo no ensaio 316MF no Trecho 4

A tabela 4.1.5 mostra a média das variáveis relevantes obtidas no Trecho 4 com motor frio.

Tabela 4.1.5 - Resultados de campo obtidos com motor frio: médias totais dos ensaios no Trecho 4

\begin{tabular}{|c|c|}
\hline Velocidade média $(\mathrm{km} / \mathrm{h})$ & 34,2 \\
\hline Consumo médio $(\mathrm{km} / \mathrm{l})$ & 20,2 \\
\hline Inclinação média no trecho $(\%)$ & $-4,9$ \\
\hline Massa de combustível $(\mathrm{g})$ & 25,3 \\
\hline Porcentagem média de emissão de CO (\%) & 1,2 \\
\hline Temperatura média ( $\left.{ }^{\circ} \mathrm{C}\right)$ na vareta de óleo de motor & 79 \\
\hline Emissão de CO no trecho (g) & 3,6 \\
\hline Emissão de HC no trecho $(\mathrm{g})$ & 0,2 \\
\hline Emissão de CO médio no trecho (g/km) & 4,8 \\
\hline Média de emissão de HC (g/km) & 0,3 \\
\hline Emissão de CO calculado pelo modelo da ANTP & 18,3 \\
\hline Emissão de HC calculado pelo modelo da ANTP & 1,5 \\
\hline
\end{tabular}

A emissão de CO medida neste trecho mostrou-se bem menor que aquela obtida no modelo da ANTP (4,8 g/km contra 18,3 g/km). Aqui, o declive 
da via associado ao motor mais aquecido (saindo de um aclive que exigiu mais do motor) e à velocidade média mais alta (com poucas intervenções, como paradas ou reduções abruptas de marcha seja em razão de paradas obrigatórias ou semáforos) favoreceu a redução. Quanto à emissão de $\mathrm{HC}(0,3 \mathrm{~g} / \mathrm{km}$ contra $1,5 \mathrm{~g} / \mathrm{km})$, mais uma vez ocorreu queda, tanto tomando como referência o valor calculado conforme a fórmula da ANTP quanto com referência às médias obtidas no trecho anterior.

Houve uma queda significativa na emissão de CO no cotejo entre ambos os trechos com o motor frio $(52,2 \mathrm{~g} / \mathrm{km}$ contra $4,8 \mathrm{~g} / \mathrm{km})$, o que se explica tanto pela inclinação da via quanto pela temperatura do motor, já um pouco mais aquecido a esta altura dos ensaios.

A tabela 4.1.6 mostra a média das variáveis relevantes obtidas no Trecho 4 com motor quente.

Tabela 4.1.6 - Resultados de campo obtidos com motor quente: médias totais dos ensaios no Trecho 4

\begin{tabular}{|c|c|}
\hline Velocidade média $(\mathrm{km} / \mathrm{h})$ & 38,9 \\
\hline Consumo médio $(\mathrm{km} / \mathrm{l})$ & 33,8 \\
\hline Massa de combustível $(\mathrm{g})$ & 15,2 \\
\hline Porcentagem média de emissão de CO $(\%)$ & 1,03 \\
\hline Temperatura média $\left({ }^{\circ} \mathrm{C}\right)$ na vareta de óleo de motor & 104 \\
\hline Emissão de CO no trecho $(\mathrm{g})$ & 1,8 \\
\hline Emissão de HC no trecho $(\mathrm{g})$ & 0,06 \\
\hline Emissão de CO médio no trecho $(\mathbf{g} / \mathbf{k m})$ & 2,5 \\
\hline Média de emissão de HC (g/km) & $\mathbf{0 , 0 8}$ \\
\hline Emissão de CO calculado pelo modelo da ANTP & 16,2 \\
\hline Emissão de HC calculado pelo modelo da ANTP & 1,3 \\
\hline
\end{tabular}

As médias obtidas para o mesmo trecho nos ensaios com o motor aquecido mostram a emissão de $\mathrm{CO}$ em níveis muito inferiores àqueles obtidos pelo modelo adotado pela ANTP: $2,5 \mathrm{~g} / \mathrm{km}$ contra 16,2 g/km. A emissão de HC também é menor: $0,08 \mathrm{~g} / \mathrm{km}$ contra $1,3 \mathrm{~g} / \mathrm{km}$. A grande diferença nos valores se explica tanto pela temperatura do motor quanto pela inclinação da via (declive acentuado).

$O$ cotejo entre o desempenho do motor frio e quente para 0 mesmo trecho leva à mesma conclusão, ou seja, de que, quando quente, o motor emite muito menos poluentes que quando frio. 
O Trecho 5 tem 3100 metros e se inicia no cruzamento da Avenida das Azaléias, seguindo pela Marginal (Avenida Trabalhador Sancarlense) até o cruzamento com a Avenida Parque Faber.

A figura 4.1.9 ilustra a Trabalhador Sancarlense, sentido Shopping em um período com poucos veículos circulando de modo a permitir visualizar sua inclinação.

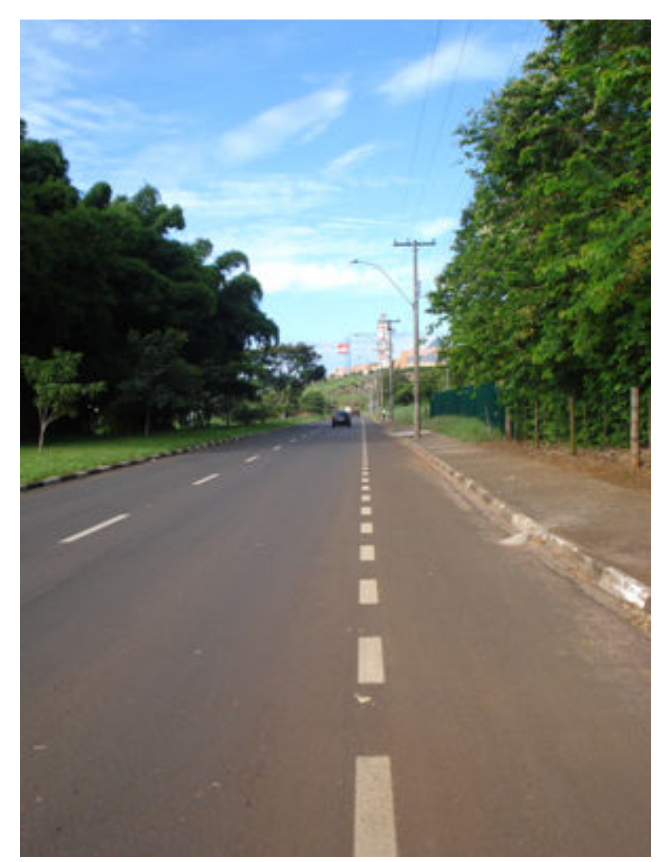

Figura 4.1.9 - Foto ilustrativa do Trecho 5 - Avenida Trabalhador Sancarlense

O trânsito neste trecho é relativamente baixo, exceto em alguns pontos como a entrada para a USP, o cruzamento com a Rua Miguel Petroni, o cruzamento com a Rua Ângelo Passeri e na entrada da Avenida Parque Faber. Neste trecho há predominância de declive. Poucos obstáculos permitem uma velocidade média maior, salvo hipóteses de desrespeito pelas normas de trânsito pelos motoristas. Há pouca movimentação de pessoas e casas comerciais. A poluição gerada nesse trecho tem boa dispersão.

A figura 4.1.10 mostra uma parte do mapa da cidade com um contorno em destaque sobre o Trecho 5 . Em verde, uma aproximação de como os pontos ficava na via, visto que em escala normal, não é possível fazer a visualização de detalhes. 


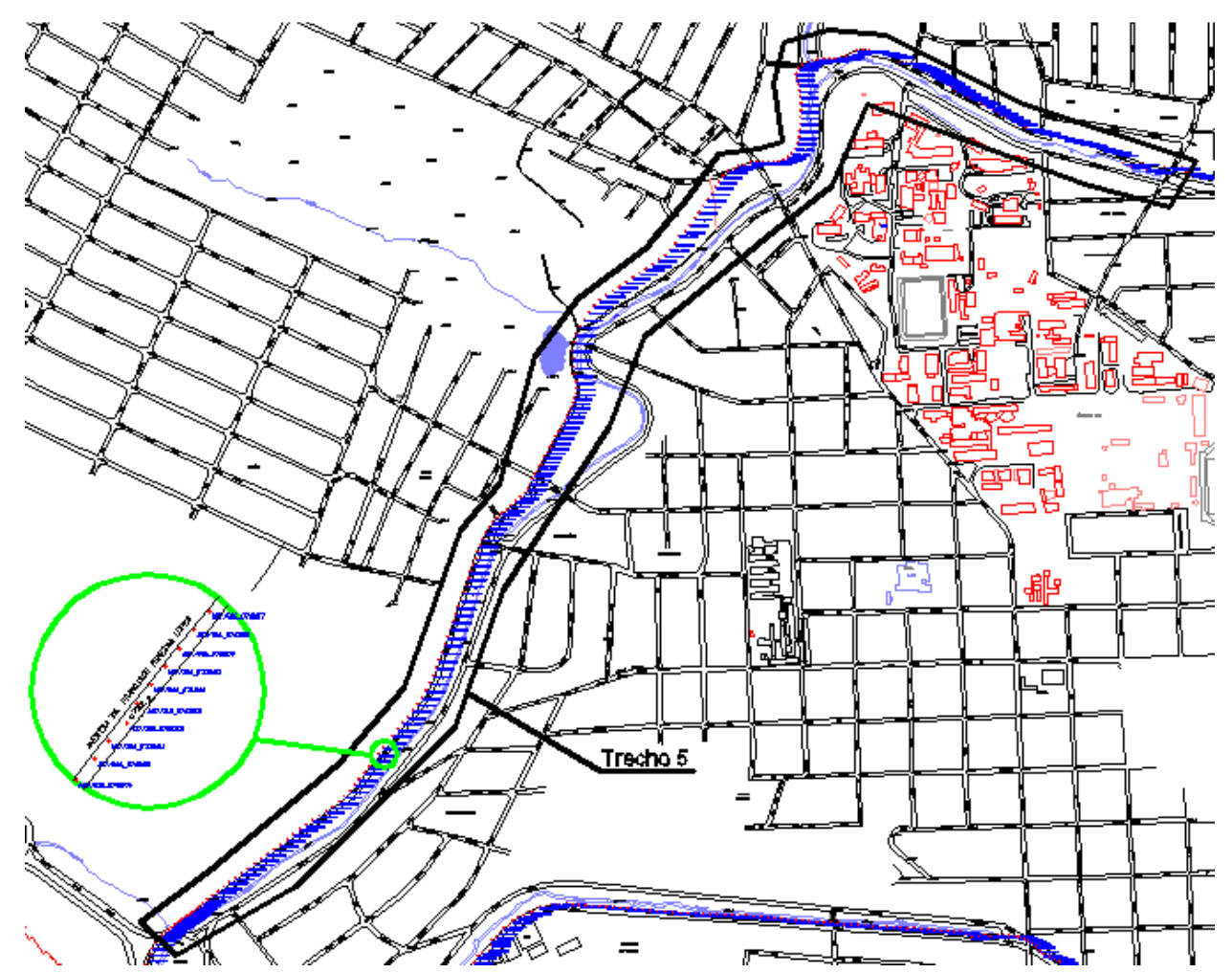

Figura 4.1.10 - Mapa ilustrativo do percurso do veículo no ensaio 316MF no Trecho 5

A tabela a seguir mostra a média das variáveis relevantes obtidas no Trecho 5 com motor quente

Tabela 4.1.7 - Resultados de campo obtidos com motor quente: médias totais dos ensaios no trecho 5

\begin{tabular}{|c|c|}
\hline Velocidade média $(\mathrm{km} / \mathrm{h})$ & 41,6 \\
\hline Consumo médio $(\mathrm{km} / \mathrm{l})$ & 17,3 \\
\hline Inclinação média no trecho $(\%)$ & $-0,8$ \\
\hline Massa de combustível $(\mathrm{g})$ & 130,3 \\
\hline Porcentagem média de emissão de CO $(\%)$ & 1,3 \\
\hline Temperatura média $\left({ }^{\circ} \mathrm{C}\right)$ na vareta de óleo de motor & 90 \\
\hline Emissão de CO no trecho $(\mathrm{g})$ & 83,4 \\
\hline Emissão de HC no trecho (g) & 4,5 \\
\hline Emissão de CO médio no trecho $(\mathbf{g} / \mathbf{k m})$ & 26,9 \\
\hline Média de emissão de HC (g/km) & 1,5 \\
\hline Emissão de CO calculado pelo modelo da ANTP & 15,3 \\
\hline Emissão de HC calculado pelo modelo da ANTP & 1,2 \\
\hline
\end{tabular}

Este trecho será analisado isoladamente, visto que foi ensaiado em condições consideradas relativamente ideais, ou seja, com velocidade média 
relativamente alta e poucas intervenções no trânsito (paradas, principalmente). A emissão média de CO mensurada ficou mais alta que a do modelo calculado pela função da ANTP $(26,9 \mathrm{~g} / \mathrm{km}$ contra $15,3 \mathrm{~g} / \mathrm{km})$. Esperava-se neste trecho que os resultados obtidos nos ensaios fossem mais próximos dos resultados obtidos por meio da função matemática da ANTP. A emissão de HC mensurada e a calculada pelo modelo da ANTP $(1,5 \mathrm{~g} / \mathrm{km}$ contra $1,2 \mathrm{~g} / \mathrm{km})$ ficaram muito próximas.

\subsection{Etapa dois}

Esta etapa consiste em analisar o comportamento da emissão dos gases em um dos ensaios, tomado como exemplo, dada a inconveniência de se analisar minuciosamente cada um dos ensaios realizados. Como os dados são semelhantes em todos os ensaios, a análise de um deles pode ser estendida para todos os outros.

Serão apresentados, portanto, os gráficos obtidos em cada segundo da medição, com a análise minuciosa de cada um dos parâmetros relevantes para este trabalho.

Foram analisados os dados obtidos nos ensaios com o motor frio e com o motor quente (2 ensaios) realizados no dia GPS 316 do ano de 2007, que faz parte dos primeiros 40 ensaios realizados. A opção recaiu sobre estes ensaios visto que, durante $\mathrm{o}$ processamento GPS, as coordenadas obtidas apresentaram-se as mais lineares, com poucos saltos e correções manuais a serem realizadas. Desse modo, dados como velocidade, aceleração, posição, inclinação da via são mais confiáveis.

Primeiramente estão apresentados todos os gráficos obtidos no ensaio com o motor frio, nos trechos de 1 a 4, tanto para a emissão de $\mathrm{CO}$ quanto para a emissão de HC. Em seguida, apresentam-se os gráficos obtidos a partir dos dados gerados no ensaio com o motor quente, ou seja, nos trechos 3 e 4, quanto à emissão de $\mathrm{CO}$ e de $\mathrm{HC}$.

Posteriormente, estão os gráficos obtidos para o trecho 5 , relativamente à emissão de $\mathrm{CO}$ e de $\mathrm{HC}$, onde os ensaios foram realizados apenas com o motor quente. $O$ trecho se diferencia em razão do percurso, como já explicitado. 
Todos os dados que fundamentam a análise deste dia de ensaio estão apresentadas no Anexo I do trabalho.

\subsubsection{Análise da emissão de CO com o motor frio}

Os gráficos relacionam a emissão de $\mathrm{CO}$ em gramas com as outras variáveis relevantes medidas durante o ensaio: porcentagem de $\mathrm{CO}$, velocidade, inclinação da via, distância percorrida, aquecimento do motor e gramas de gasolina acumulada.

Em todos os gráficos, há um aumento final na emissão de CO que se explica pela manobra de estacionamento do veículo em marcha à ré para desligamento dos aparelhos. No eixo das abscissas foi colocado o tempo em segundos, no eixo das ordenadas do lado esquerdo os valores referentes aos dados mensurados das variáveis relevantes e do lado direito os dados relativos à emissão de $\mathrm{CO}$ ou $\mathrm{HC}$ em gramas.

O gráfico 4.2.1 faz uma comparação entre a porcentagem de CO mensurada e sua emissão em gramas. Uma porcentagem de emissão de CO alta associada a um consumo instantâneo alto resulta em uma alta emissão em gramas de CO.

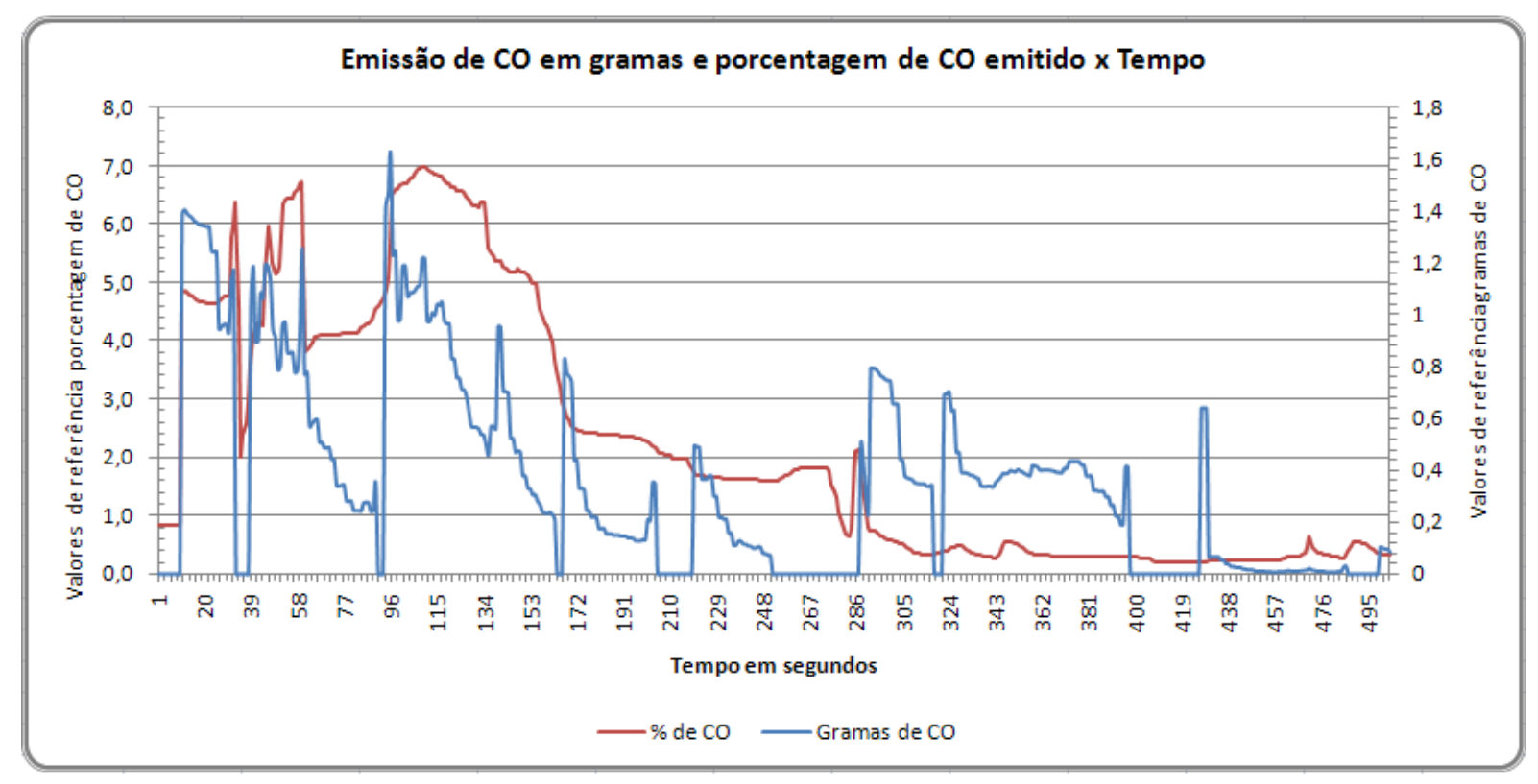

Gráfico 4.2.1 - Gramas CO e \% CO x Tempo 
A forma como os dados foram obtidos e processados não permite que se mensure a quantidade de emissão de $\mathrm{CO}$ quando a velocidade é zero. Assim, nos gráficos, apresenta-se uma descontinuidade nesses períodos.

$\mathrm{O}$ analisador de gases obtém a porcentagem de emissão de CO com relação ao total dos gases expelidos pelo escapamento, com ou sem movimento do veículo. Mas a massa de CO só é possível de ser obtida, neste modelo, se o veículo estiver em movimento, onde se consegue mensurar seu consumo.

Sabe-se que quando o veículo está parado, ocorre uma queda na emissão de $\mathrm{CO}$, mas esta não chega a zero, gerando a descontinuidade na linha azul do gráfico (gramas de $\mathrm{CO}$ ). Esse fato gera como consequência que as médias obtidas nos ensaios (analisadas no item 4.1) são um pouco mais elevadas que as apresentadas, entretanto, não foi possível mensurar essa diferença.

A porcentagem de emissão de CO é maior quando o motor está ainda frio, ou seja, no início do percurso. Conforme o motor se aquece, há alguns picos de emissão de CO em gramas (p. ex., segundos 135, 169, 430), que não são acompanhados pelo aumento na porcentagem de emissão. Pode-se concluir, portanto, que tanto a porcentagem de emissão de CO quanto sua emissão em gramas se referencia principalmente com relação à temperatura do motor, ficando mais baixa e regular conforme o motor está mais aquecido. Quanto mais frio o motor, maiores os picos e mais tempo decorre para sua emissão diminuir.

Assim, não é possível afirmar que uma baixa emissão de CO em porcentagem significa uma baixa emissão de $\mathrm{CO}$ em gramas e o que mais importa efetivamente para a verificação da qualidade do ar é a emissão em gramas.

O gráfico 4.2.2 mostra a relação entre a velocidade e a emissão em gramas de CO. 


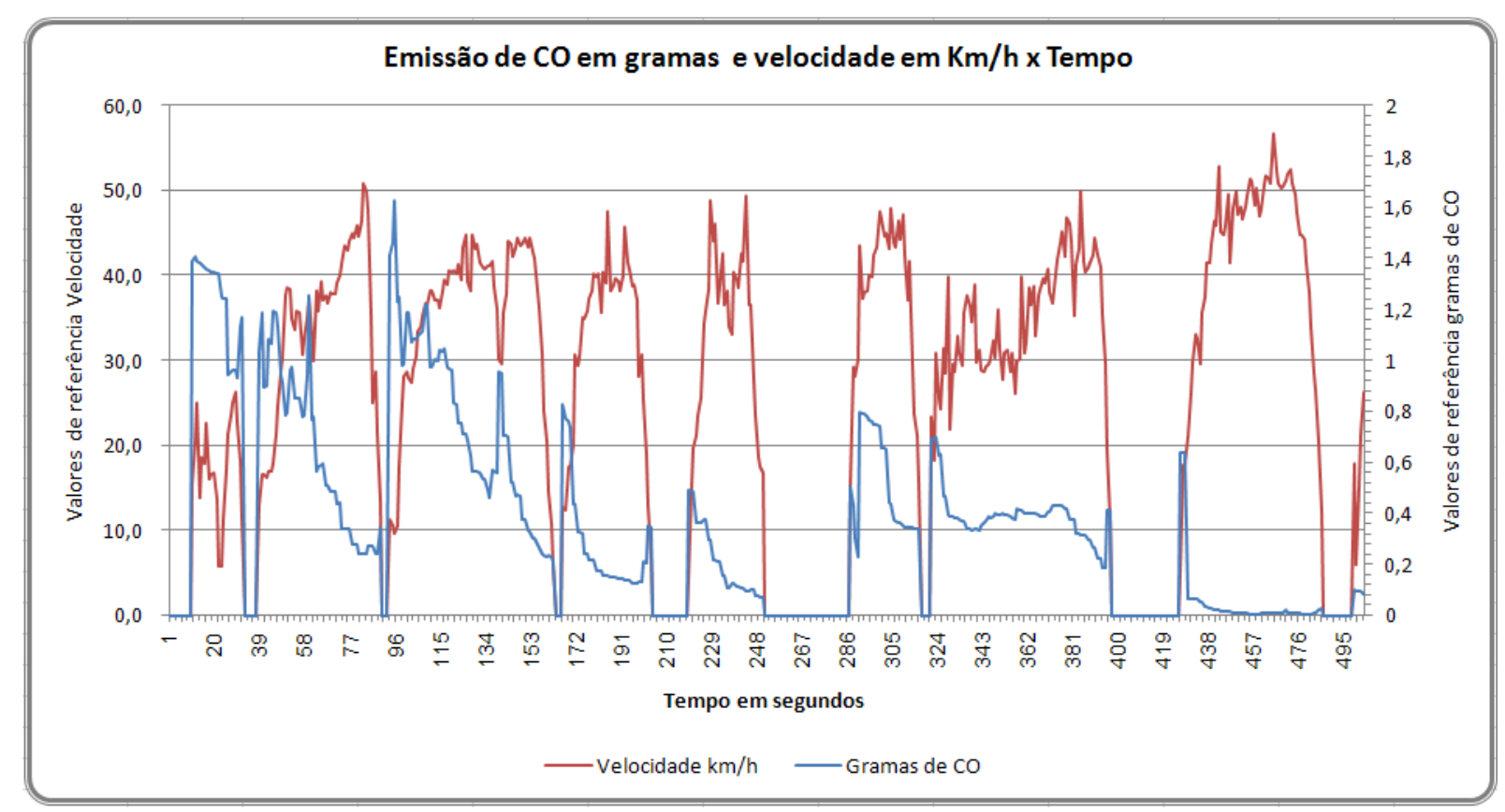

Gráfico 4.2.2 - Gramas CO e Velocidade x Tempo

Por meio do gráfico 4.2.2, é possível notar que quantidade de gramas de CO emitida varia, em alguns trechos, de acordo com a variação da velocidade, o que confirmaria os dados levantados de acordo com a fundamentação teórica. O modelo da ANTP para descrever a emissão de CO em gramas, tomado como prototípico para a comparação dos dados obtidos neste estudo, se baseia unicamente nesta relação. Porém em outros trechos a velocidade aumenta e a emissão de $\mathrm{CO}$ em gramas diminui.

É interessante notar, por exemplo, que entre os segundos 421 e 481, houve um aumento de velocidade acompanhado de uma queda na emissão de $\mathrm{CO}$ em gramas. Apesar de não estar apresentado neste gráfico (ver gráfico 4.2.3), sabe-se que esse fato se deve ao declive da via, o que demonstra que os modelos que se baseiam unicamente em dados de velocidade, para as situações ensaiadas, apresentam grandes distorções.

Ressalte-se, mais uma vez, que, apesar de a velocidade ser zero, a emissão de $\mathrm{CO}$ em gramas fica sem dados, mas não será zero.

O gráfico 4.2.3 mostra a relação entre e o perfil vertical do percurso e a emissão em gramas de $\mathrm{CO}$, ilustrando sua inclinação. 


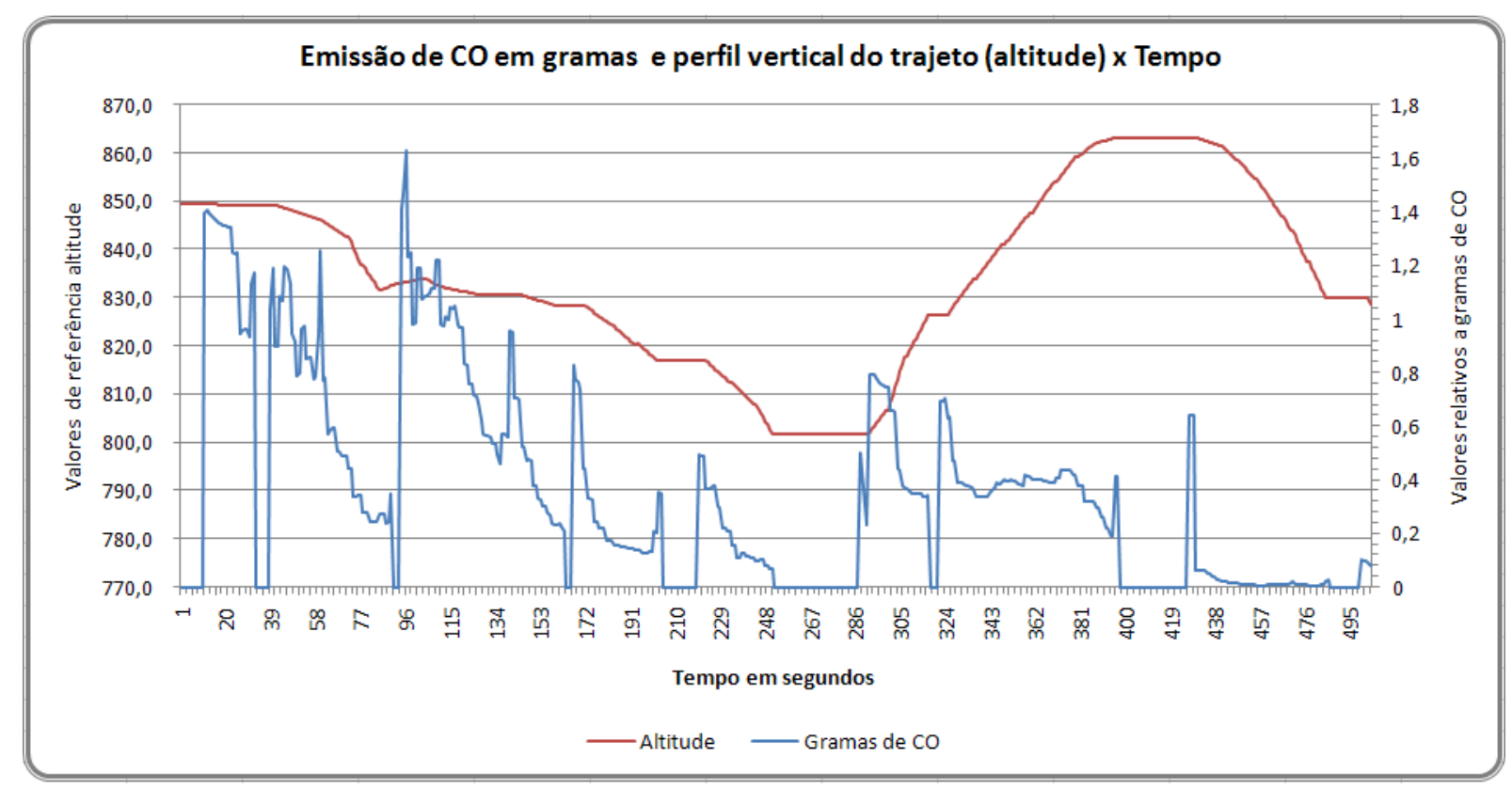

Gráfico 4.2.3 - Gramas CO e Altitude x Tempo

No gráfico 4.2.3, a relação entre a emissão de CO em gramas com a inclinação da via torna-se notável. No início, com o motor frio, a emissão de CO é alta, independentemente do perfil da via. Entretanto, com o aumento da temperatura do motor, a inclinação da via passa a ser significativa. As grande quedas verticais na emissão em gramas de $\mathrm{CO}$ vistas no gráfico se referem à falha de coleta de dados quando a velocidade é zero, já discutida anteriormente. Assim, olhando-se os três dados juntos fica mais fácil sua compreensão.

O gráfico 4.2.4 mostra a relação entre a emissão em gramas de $\mathrm{CO}$, a velocidade e o perfil vertical. 


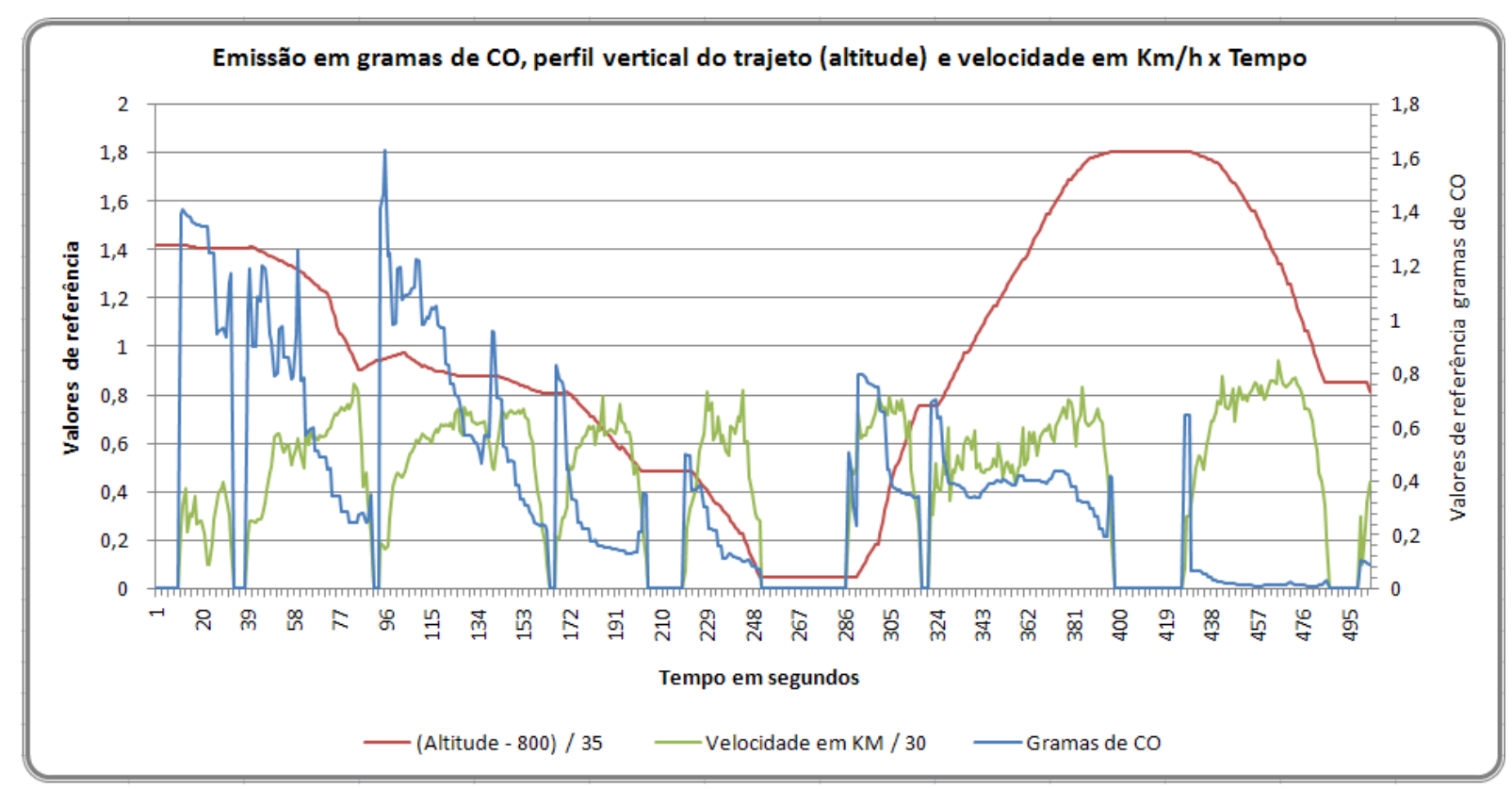

Gráfico 4.2.4 - Gramas CO, Altitude e Velocidade x Tempo

Apesar de dificultar a legibilidade, optou-se por apresentar um gráfico com os três dados relacionados nos dois gráficos anteriores, já que há influência direta entre eles. Assim, houve manipulação dos dados para que todos ficassem visíveis na proporção entre 0 e 2, que é a quantidade de emissão de CO em gramas. Foram subtraídos da altitude $800 \mathrm{~m}$, que representam a altitude média da cidade de São Carlos com relação ao nível do mar, para que a variação do desnível ficasse apenas em aproximadamente $70 \mathrm{~m}$. Esse valor foi dividido por 35 para que o resultado ficasse em valores próximos às gramas de CO emitida, ou seja, entre 0 e 2 e a velocidade foi dividida por 30.

No gráfico 4.2.4, portanto, fica claro que a emissão de CO varia mais em decorrer da temperatura e da inclinação do trajeto do que apenas da velocidade. Porém a variação com base na altitude se mostra mais significativa quando o motor está mais aquecido. Por exemplo, analisando o segundo 75. Nele ocorre um aumento na velocidade, porém está em um trecho de declive e a emissão em gramas de $\mathrm{CO}$ diminui,

O gráfico 4.2.5 mostra a relação entre a emissão em gramas de CO pela distância percorrida. 


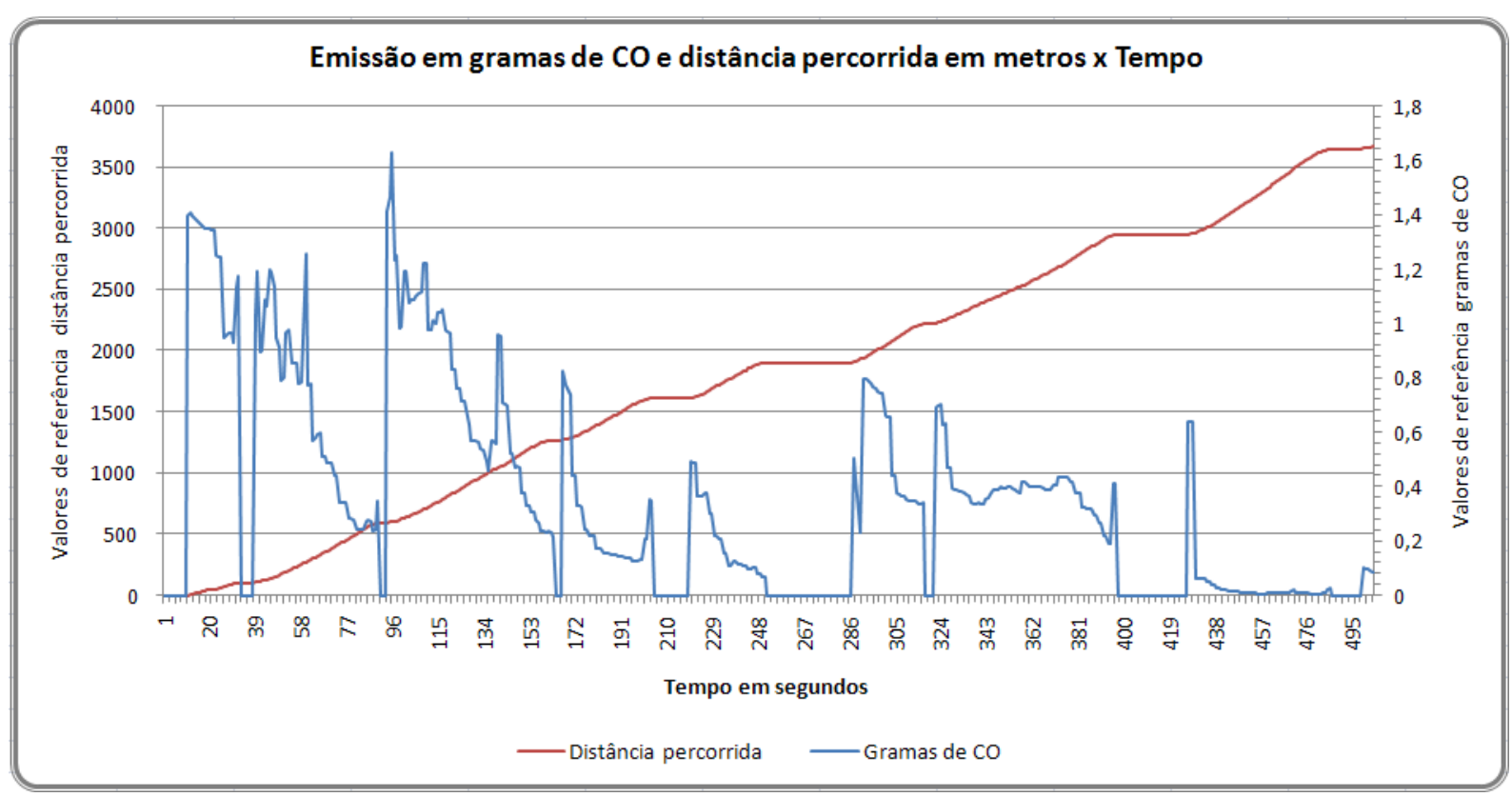

Gráfico 4.2.5 - Gramas CO e Distância x Tempo

O gráfico 4.2.5 apresenta a relação entre a emissão de $\mathrm{CO}$ em gramas e a distância percorrida. É possível verificar que a emissão de CO cai com o aumento do percurso, o que ocorre em razão do aquecimento do motor. Por volta dos $3.000 \mathrm{~m}$ fica claro que a emissão de $\mathrm{CO}$ é bem mais baixa que no início do percurso, o que ocorre tanto em razão do aquecimento do motor quanto pelo declive do terreno neste intervalo do percurso.

Até o primeiro quilômetro, mesmo havendo declividade da via, a emissão de $\mathrm{CO}$ é grande. Depois, em torno dos $2.000 \mathrm{~m}$ há um outro pico, o que se explica pela inclinação do terreno: trata-se do início do trecho 3 , aquele que mostra maior aclive nos ensaios propostos.

O gráfico 4.2.6 mostra a relação entre a emissão em gramas de CO pela temperatura mensurada no termopar. 


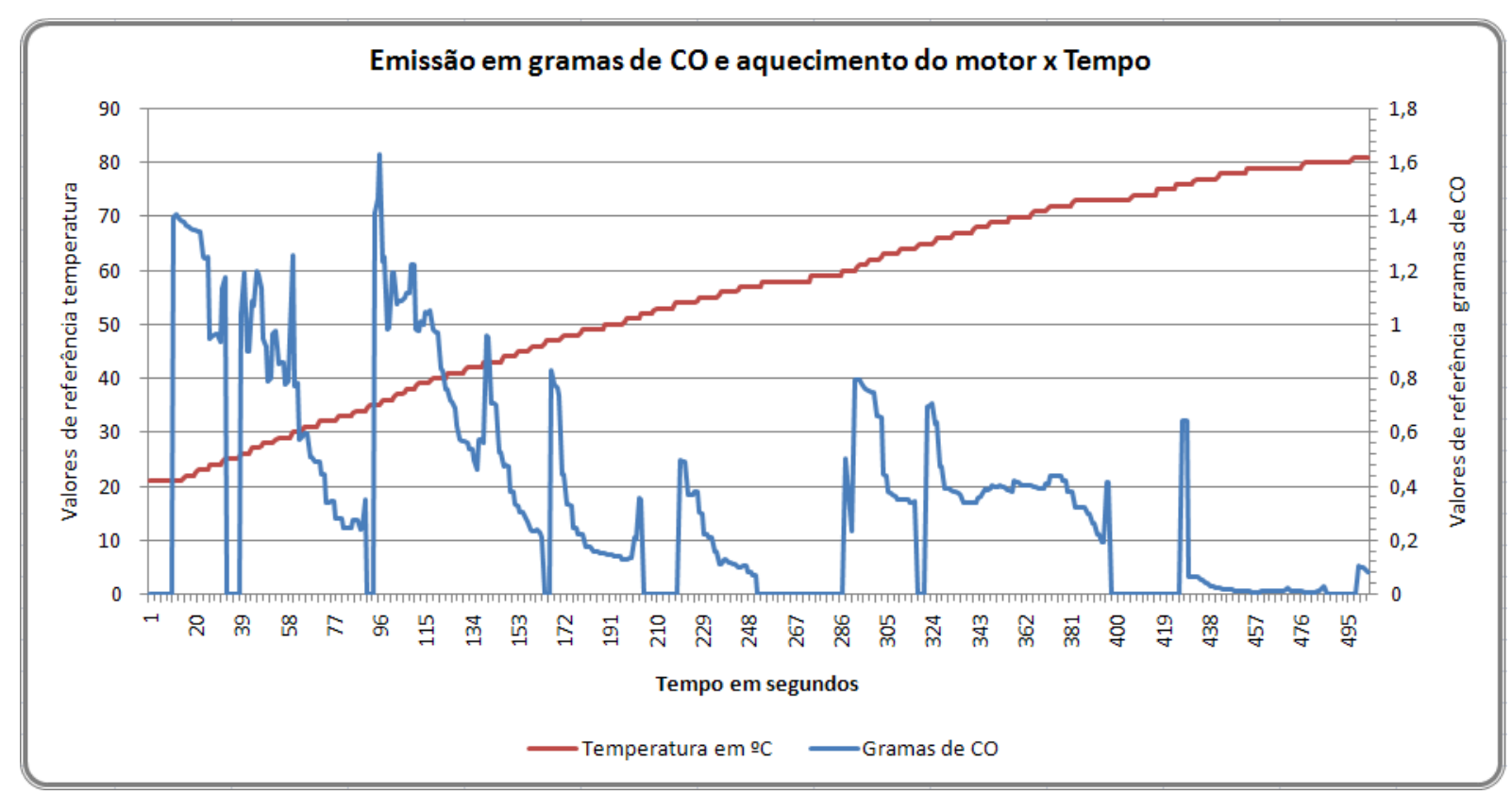

Gráfico 4.2.6 - Gramas CO e Aquecimento do motor x Tempo

A partir dos dados apresentados no gráfico 4.2.6, pode-se concluir que ocorre uma diminuição no consumo de $\mathrm{CO}$ em gramas conforme aumenta a temperatura do motor. Esses dados levam à conclusão de que, em trajetos curtos, onde o motor está frio, a emissão de CO é muito grande.

Os modelos matemáticos em geral, usados para estimar a emissão de $\mathrm{CO}$, costumam basear os dados apenas a partir do aquecimento do motor, o que pode gerar distorções em cidades pequenas e médias, onde os percursos são, na maioria, curtos. Assim, em um percurso de 10 minutos, grande parte dele tem alta emissão de $\mathrm{CO}$, ao passo que, em um percurso de 40 minutos, até os 7-10 minutos iniciais, em que o motor está frio e em que há maior emissão de $\mathrm{CO}$, ficam diluídos no volume total de emissão. Eis a distorção dos modelos tradicionais, que não são adequadamente aplicáveis às cidades pequenas e médias.

O gráfico 4.2.7 mostra a relação entre a emissão em gramas de CO pelo consumo em gramas de combustível. Esse gráfico é interessante porque mostra segundo a segundo quanto o motor consome de combustível e quanto ele gera de emissão em gramas de CO. 


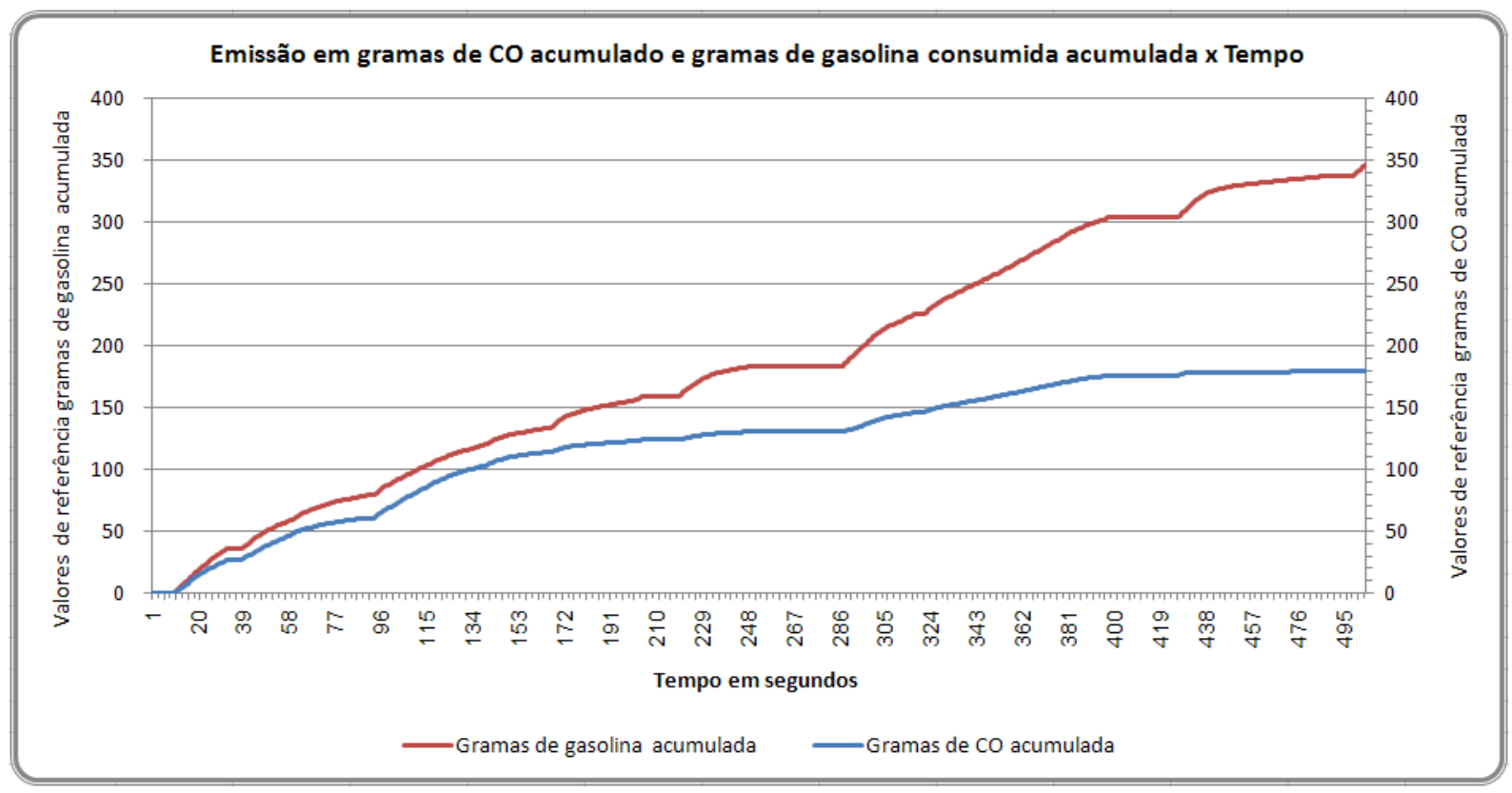

Gráfico 4.2.7 - Gramas CO e Gramas Gasolina x Tempo

A relação entre a quantidade de gramas de $\mathrm{CO}$ e de gasolina acumuladas permite avaliar a eficiência da queima do combustível. Verifica-se, portanto, que o motor se torna mais eficiente no decorrer do tempo, em virtude da temperatura, ocorrendo uma emissão menor de $\mathrm{CO}$ em comparação com o consumo de gasolina. Quanto melhor a queima de combustível, menor deve ser a emissão de co.

\subsubsection{Análise da emissão de HC com o motor frio}

Os gráficos relacionam a emissão de $\mathrm{HC}$ em gramas com as outras variáveis relevantes medidas durante o ensaio: porcentagem de $\mathrm{HC}$, velocidade, inclinação da via, distância percorrida, temperatura do motor e gramas de gasolina acumulada.

Em todos os gráficos, há um aumento final na emissão de HC que se explica pela manobra de estacionamento do veículo em marcha à ré para desligamento dos aparelhos.

O gráfico 4.2.8 mostra a comparação entre a emissão em gramas de $\mathrm{HC}$ pela porcentagem de $\mathrm{HC}$ emitido. 


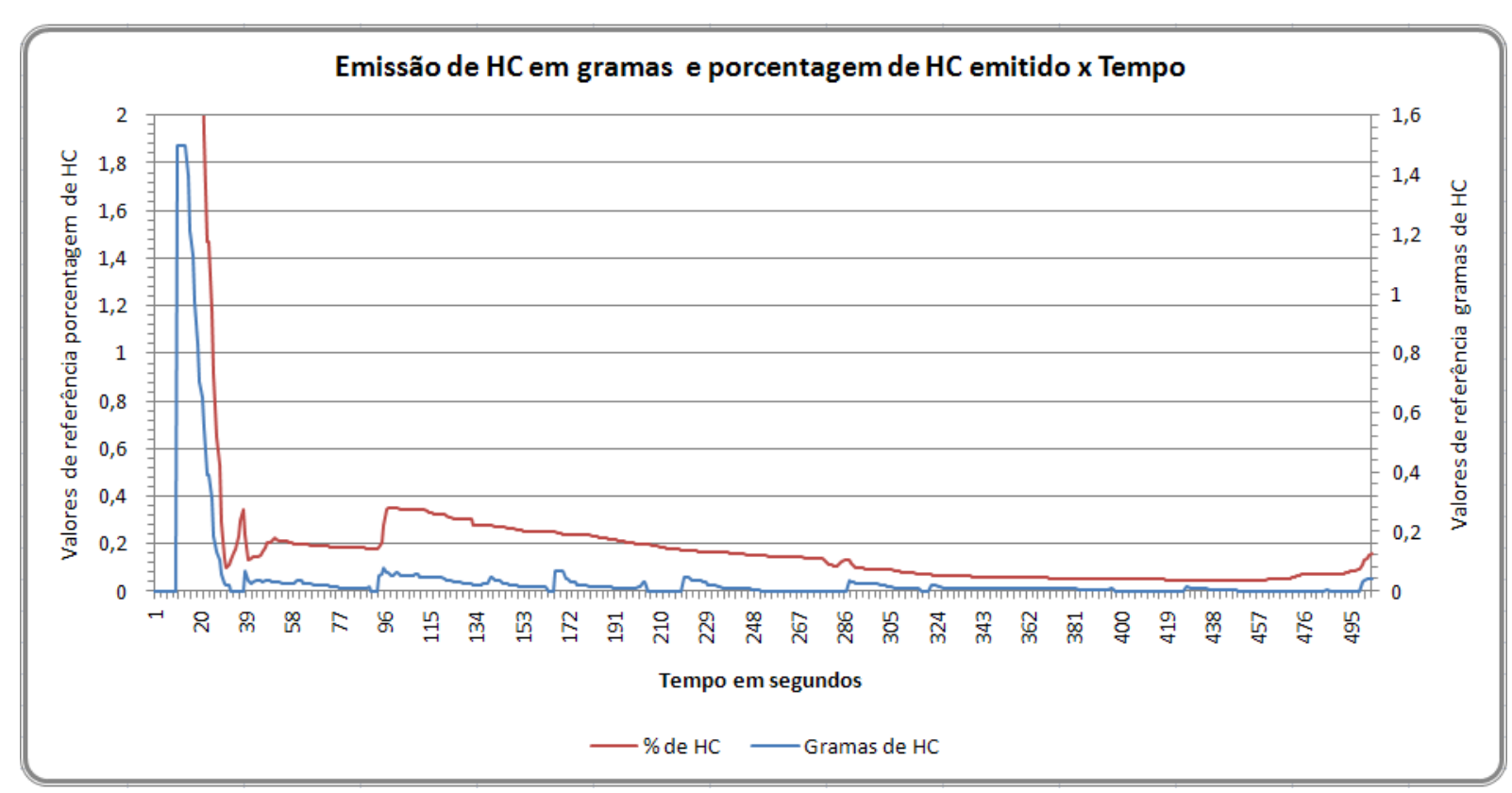

Gráfico 4.2.8 - Gramas HC e \% HC x Tempo

No gráfico 4.2.8 é possível visualizar que, logo no início do ensaio, a porcentagem de $\mathrm{HC}$ emitida em relação à quantidade de gás lançada pelo escapamento é muito alta, o que também ocorre com relação à quantidade de gramas emitida. Isso ocorre principalmente pela baixa temperatura do motor. Entretanto, esses valores se reduzem rapidamente e passam a ser baixos durante quase todo o percurso, se comparados à emissão de CO (ver gráfico 4.2.1). Assim, no ensaio, a emissão de $\mathrm{HC}$ se mostrou mais crítica no início quando o motor estava mais frio.

O gráfico 4.2.9 mostra a relação entre a emissão em gramas de $\mathrm{HC}$ pela velocidade. 


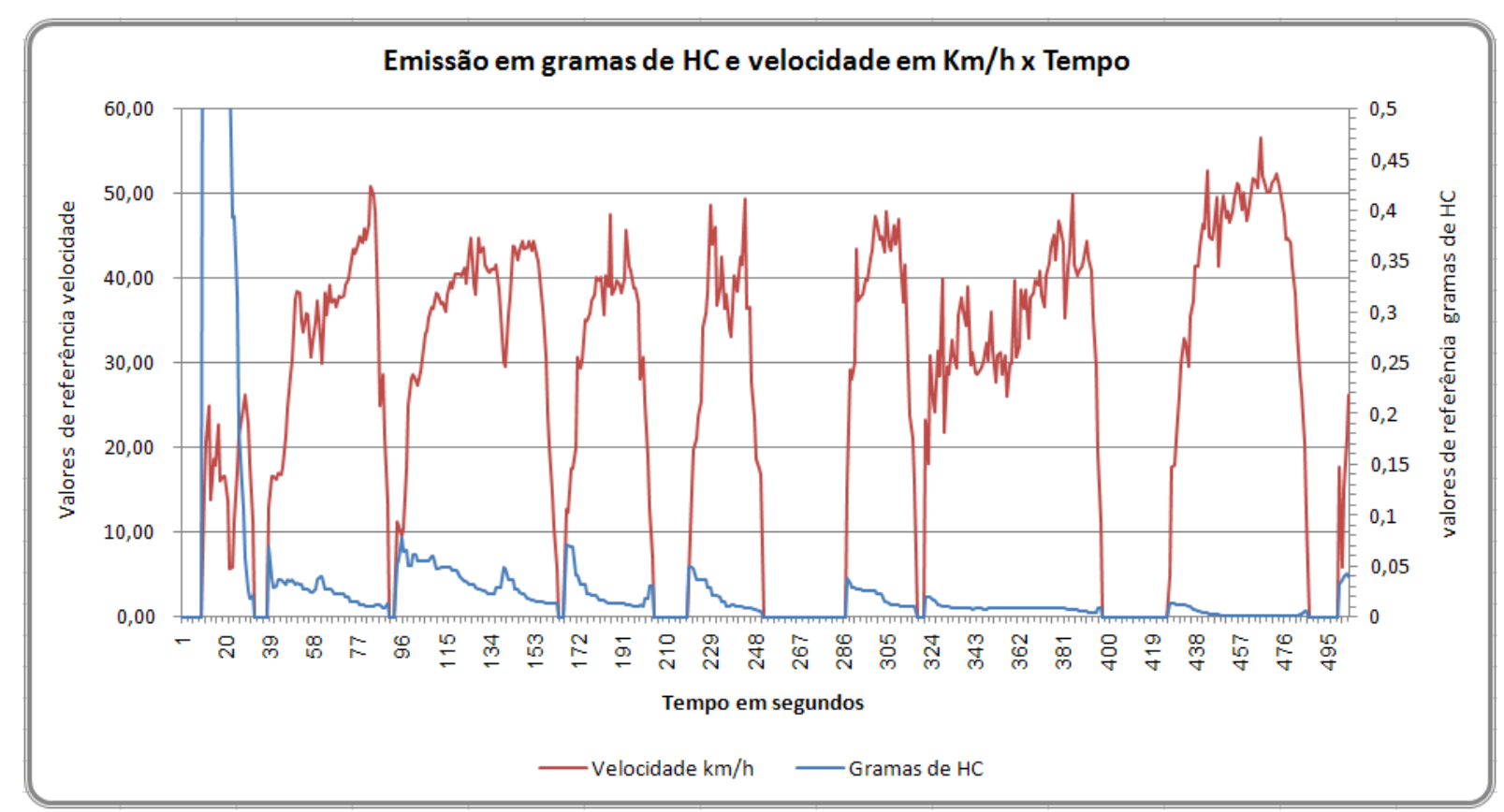

Gráfico 4.2.9 - Gramas HC e Velocidade x Tempo

No início do ensaio, enquanto o motor ainda está frio, não há uma relação visível entre a velocidade e a emissão de $\mathrm{HC}$ em gramas. O pico inicial, até por volta do segundo 31 , se explica pela baixa temperatura do motor. A partir daí, há relação entre a quantidade de gramas de $\mathrm{HC}$ emitida e a velocidade segue a mesma explicação que o gráfico 4.2.2. NO final do ensaio, a quantidade de HC emitida em gramas se estabiliza, com valores relativamente baixos, o que se explica pelo aquecimento do motor e da declividade do trecho, não tendo uma relação significativa com a velocidade.

O gráfico 4.2.10 mostra a relação entre a emissão em gramas de HC pelo perfil vertical do percurso, ilustrando sua inclinação. 


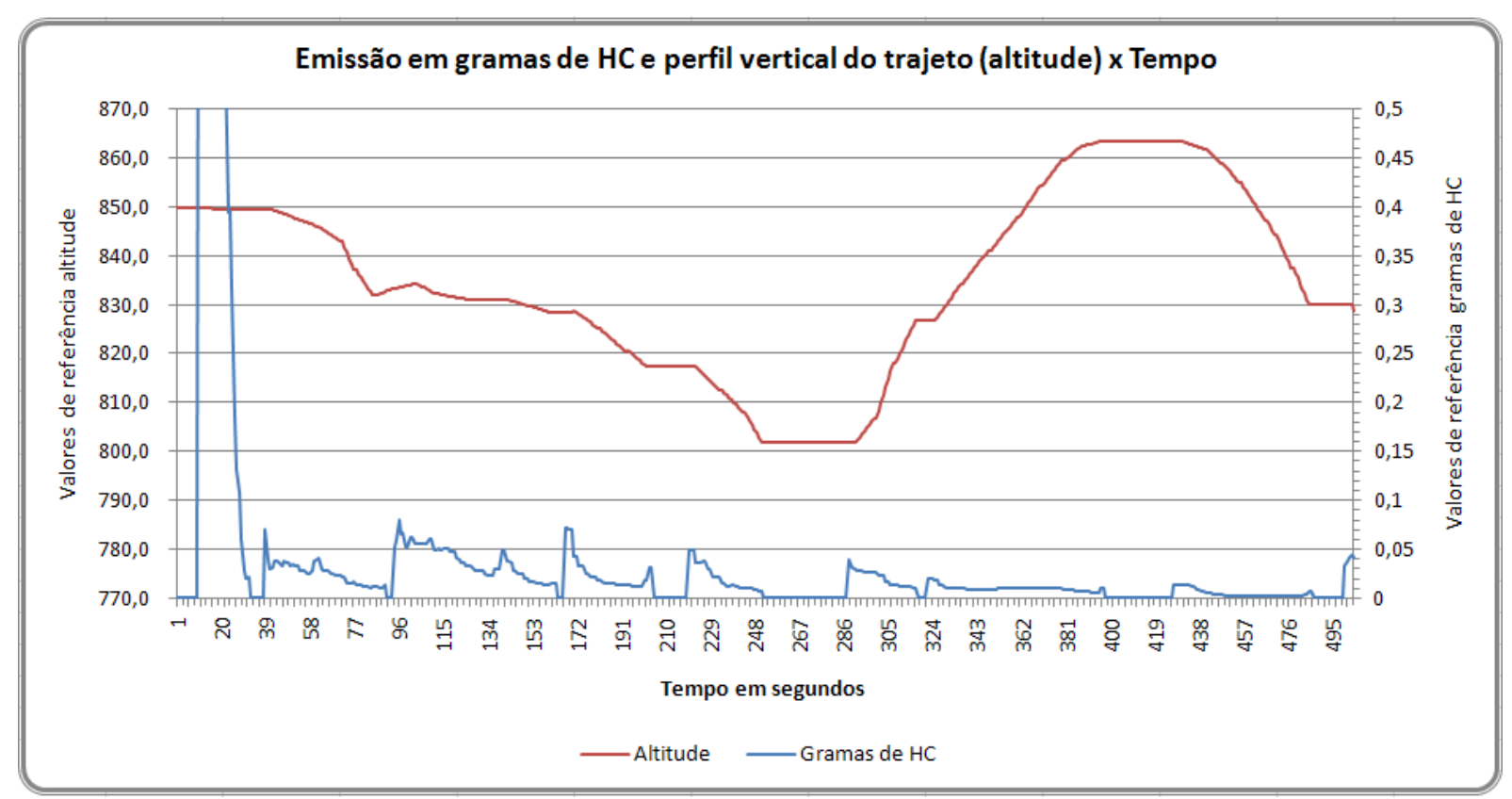

Gráfico 4.2.10 - Gramas HC e Altitude x Tempo

Verifica-se aqui que a relação entre a emissão de $\mathrm{HC}$ e a inclinação do trajeto é muito pequena e que, mais uma vez, o que realmente importa no que se refere à emissão de $\mathrm{HC}$ é a temperatura.

O gráfico 4.2.11 mostra a relação entre a emissão em gramas de HC pela distância percorrida.

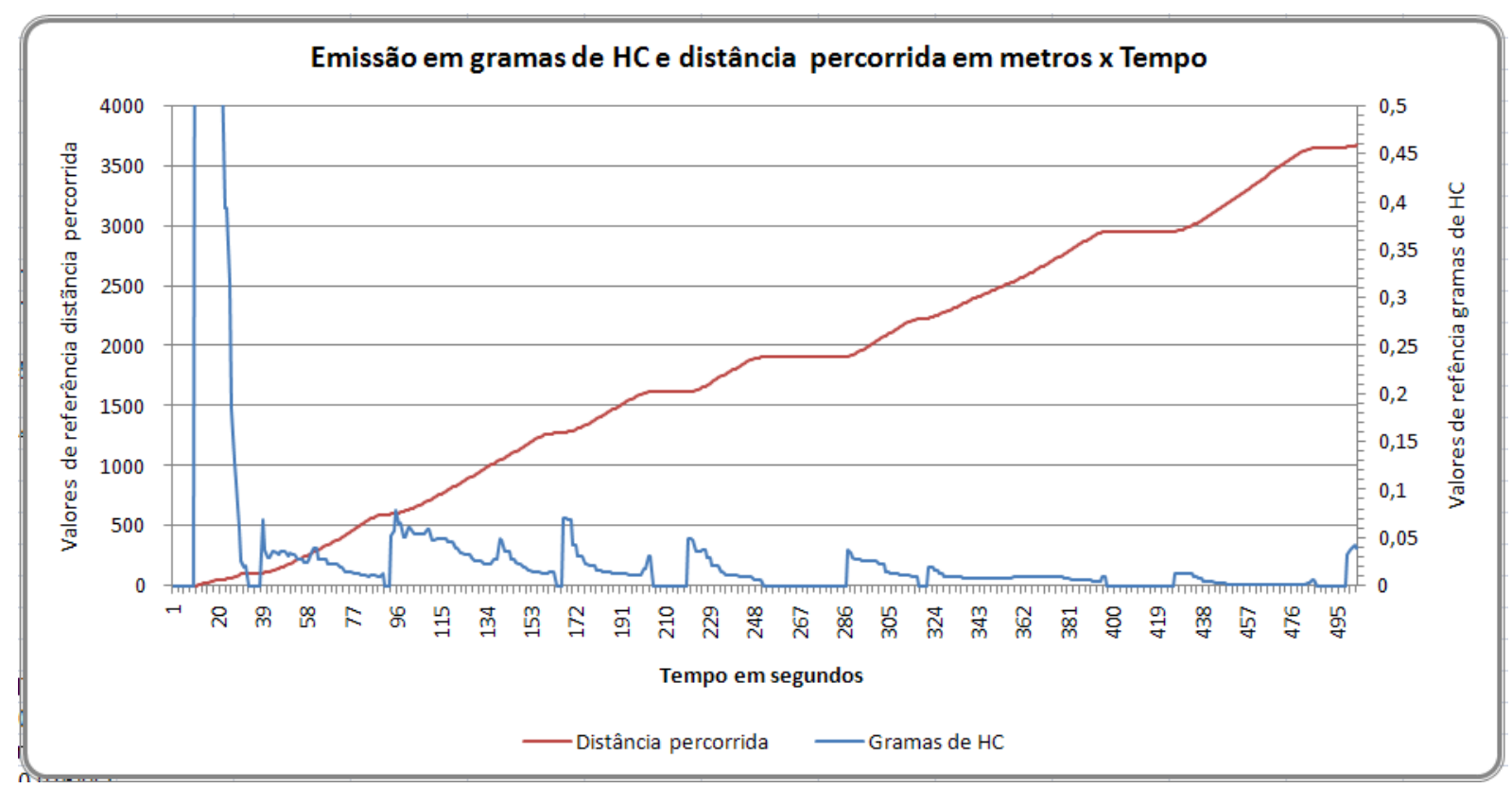

Gráfico 4.2.11 - Gramas HC e Distância x Tempo 
A relação entre a quantidade de emissão de $\mathrm{HC}$ em gramas e a distância percorrida se dá em virtude do aumento da temperatura, o que ocorre naturalmente com o aumento da distância percorrida.

É importante ressaltar que a relação com a distância só se torna relevante em razão de se relacionar diretamente com o aquecimento do motor. Se o veículo ficasse parado durante determinado período, ou seja, com deslocamento zero, a emissão de HC se reduziria da mesma forma, já que o motor se aquece independentemente de deslocamento.

O gráfico 4.2.12 mostra a relação entre a emissão em gramas de $\mathrm{HC}$ pela temperatura mensurada pelo termostato.

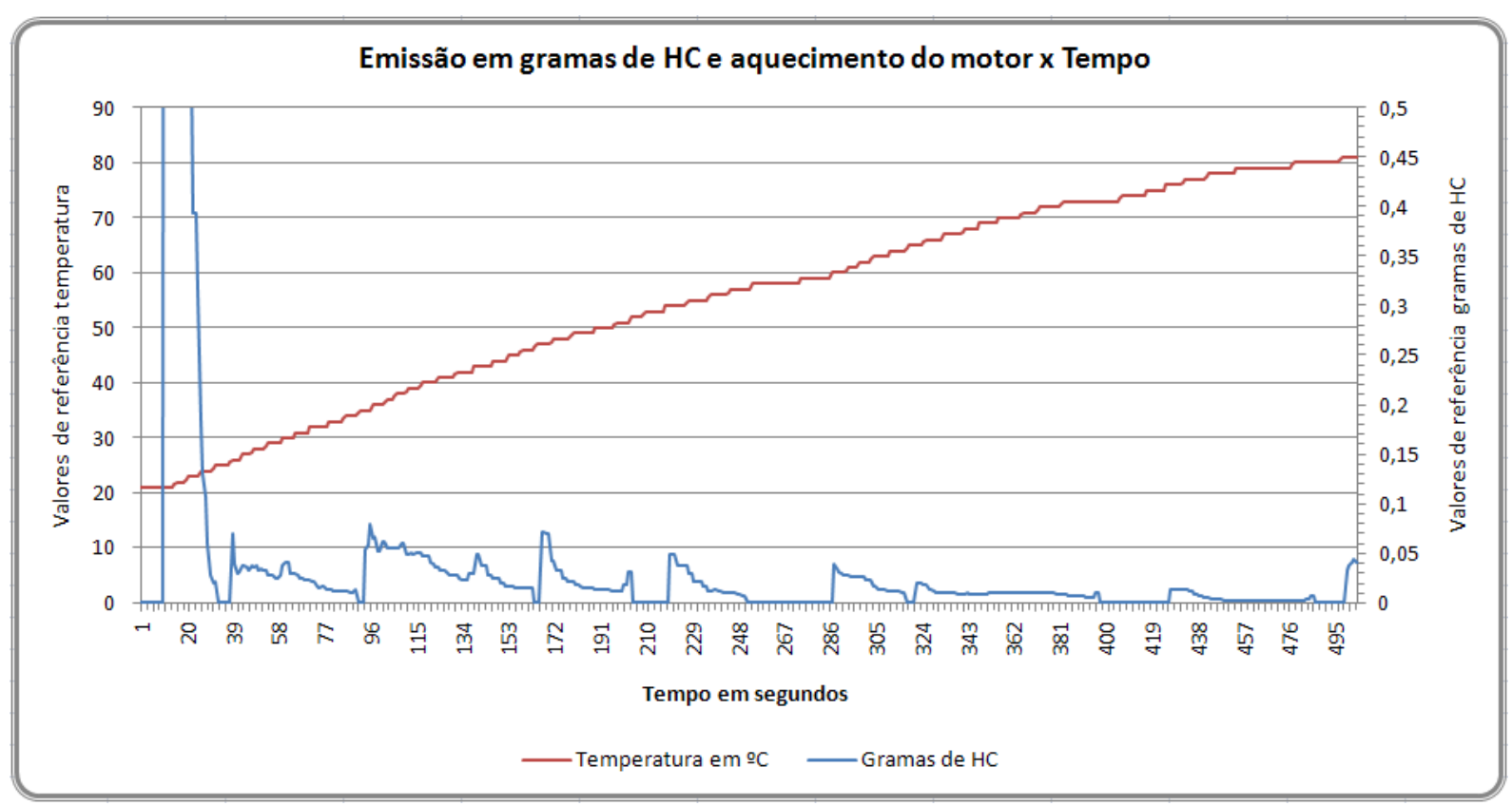

Gráfico 4.2.12 - Gramas HC e Aquecimento do motor x Tempo

Optou-se por apresentar o gráfico com o alto pico inicial de emissão de $\mathrm{HC}$ em gramas, o que dificulta a compreensão da relação entre a temperatura e a emissão de $\mathrm{HC}$.

Entretanto, observando-se atentamente os dados, é possível afirmar que existe uma relação entre os dados: a emissão de $\mathrm{HC}$ reduz com o aumento da temperatura, onde os picos tornam-se cada vez menores.

O gráfico 4.2.13 mostra a relação entre a emissão em gramas de $\mathrm{HC}$ pelo consumo instantâneo de gasolina em gramas. 


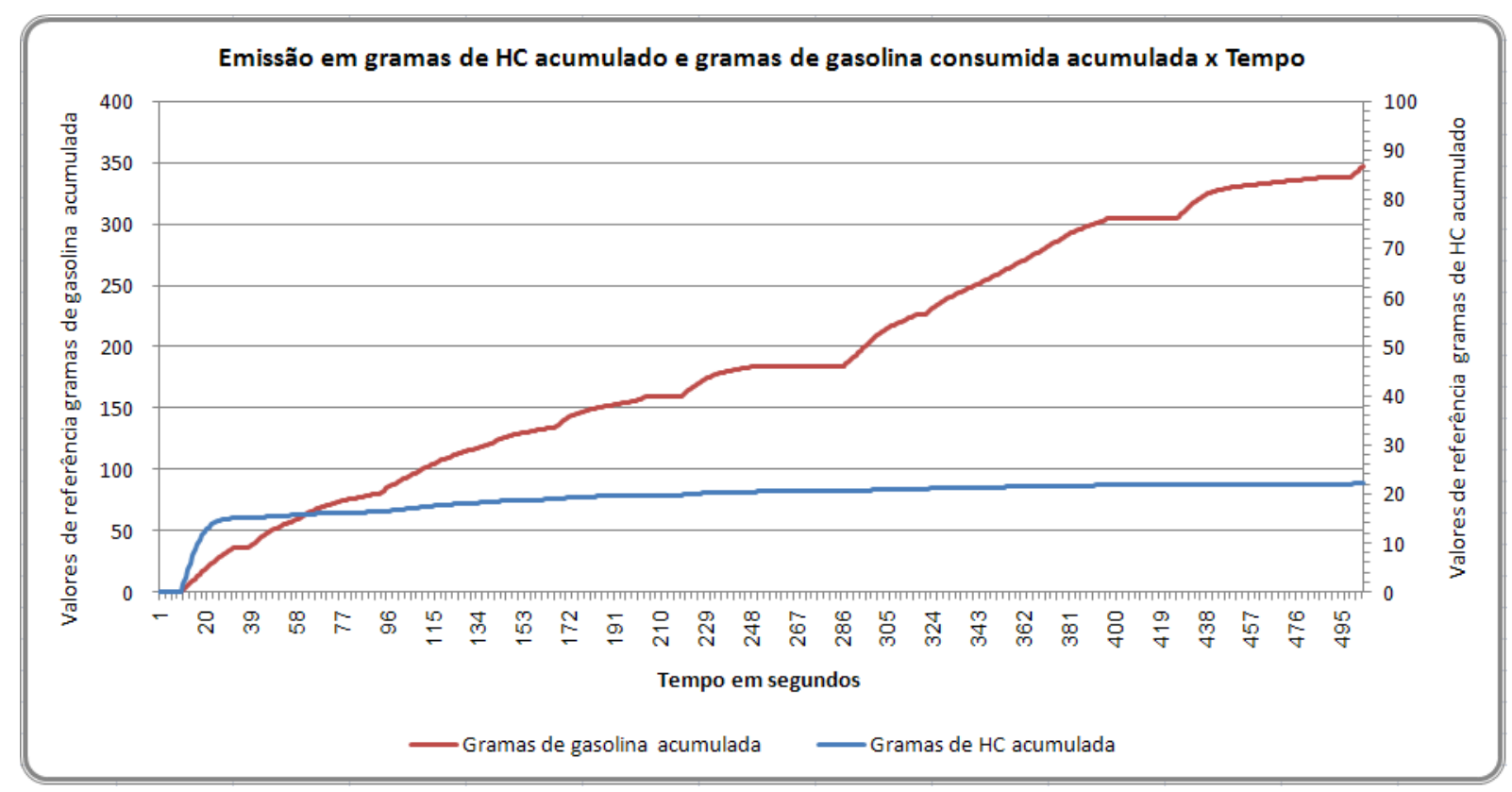

Gráfico 4.2.13 - Gramas HC e Gramas gasolina x Tempo

Nos momentos iniciais, já aparece o grande quantidade de $\mathrm{HC}$ emitida pelo motor, ou seja, a maior parte de lançamento de $\mathrm{HC}$ na atmosfera ocorre logo no início do ensaio. No decorrer do percurso, soma-se pouco à quantidade de emissão total de HC: percebe-se, pelo gráfico, que o aumento no total de emissão não é significativo entre os segundos 380 a 495.

Assim, o que mais importa para a mensuração da emissão de HC são os momentos iniciais de um ensaio, em que o motor ainda está frio, o que, em regra, deixa de ser considerados nos modelos convencionais.

\subsubsection{Análise da emissão de CO com o motor quente}

Os gráficos relacionam a emissão de $\mathrm{CO}$ em gramas com as outras variáveis relevantes medidas durante o ensaio: porcentagem de $\mathrm{CO}$, velocidade, inclinação da via, distância percorrida, temperatura do motor e gramas de gasolina acumulada.

Entre os segundos 1 e 37, o veículo saiu da vaga em que estava estacionado para que os aparelhos fossem ligados e parou no semáforo. Apenas a partir do segundo 37 é que se inicia o aclive que se pretende observar mais atentamente a partir dos gráficos desta sessão. 
O gráfico 4.2.14 mostra a comparação entre a emissão em gramas de $\mathrm{CO}$ pela porcentagem de $\mathrm{CO}$ emitido.

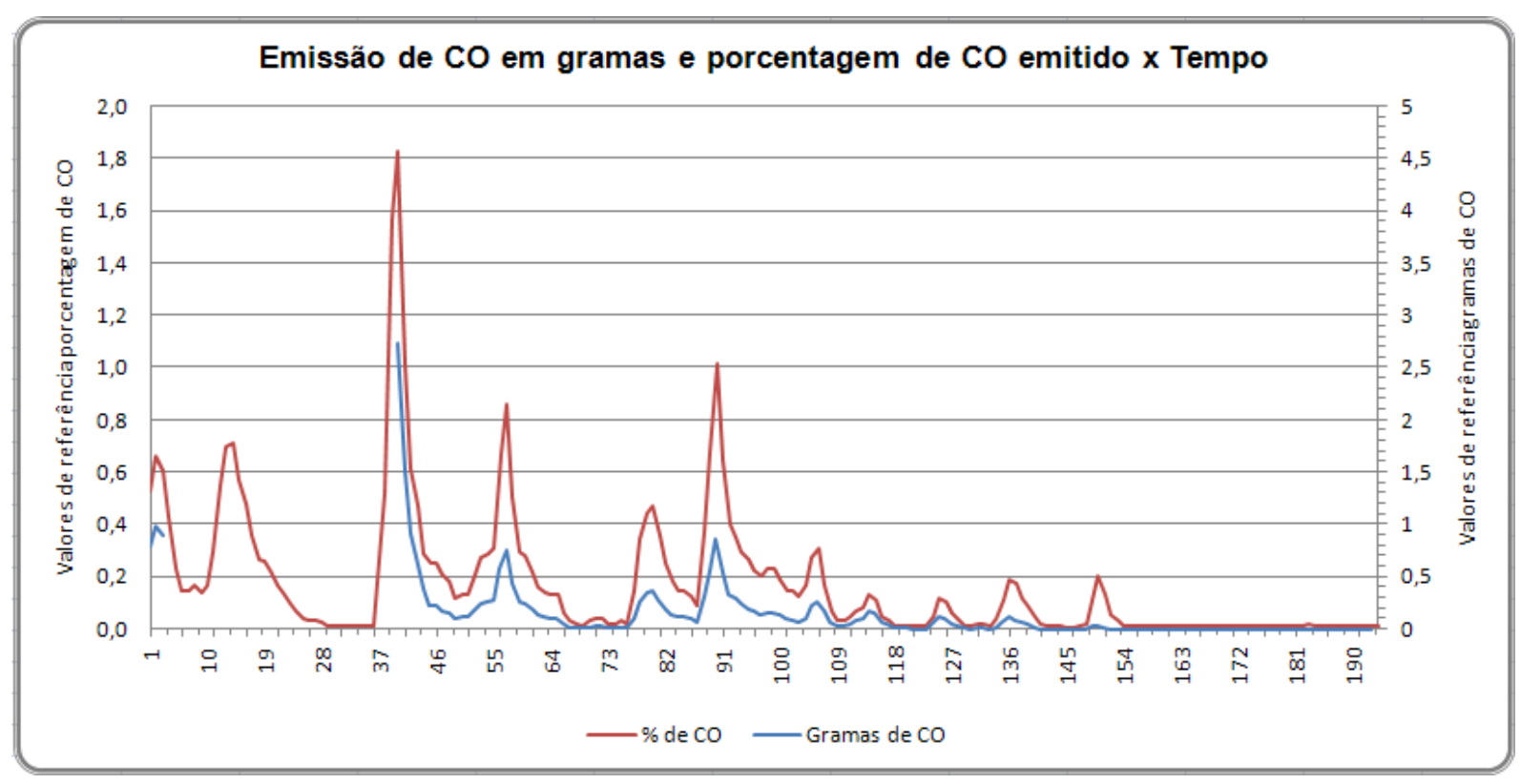

Gráfico 4.2.14 - Gramas CO e \% CO x Tempo

O aclive mais inclinado de todo o percurso (após o segundo 37, aproximadamente) realmente apresenta a maior emissão de $\mathrm{CO}$, tanto em grama quanto em porcentagem. Os demais picos mostram os efeitos do aclive e da aceleração do veículo. Note o instante inicial do movimento do veículo, onde as emissões também são elevadas. Para o veículo entrar em movimento há uma emissão notável.

A partir do segundo 111 (aproximadamente), não ocorre mais o aclive acentuado, o que gera a diminuição da emissão de CO tanto em gramas quanto em porcentagem. Os picos de porcentagem de emissão de $\mathrm{CO}$ no declive não são acompanhados pelo mesmo tipo de variação na quantidade em gramas, o que se explica pelo fato de o escapamento expelir muitos gases sem consumir muito combustível nessas condições (o motor corta o consumo de combustível em condições favoráveis - motor quente em declive sem aceleração).

Em comparação com os dados obtidos com o motor frio, as diferenças são grandes (cf. gráfico 4.2.1). Com relação às gramas de $\mathrm{CO}$, o maior pico de emissão com o motor quente chega a cerca de $0,5 \mathrm{~g}$; com o motor frio, esse pico chega a cerca de $1,5 \mathrm{~g}$ e passa de 0,5 quase que durante todo o ensaio. Esse 
valor fica menor apenas após o segundo 430 (aproximadamente), ou seja, ao final do ensaio, quando o motor já está mais aquecido. Lembrando que o analisador de gás usado tem resolução de $0,01 \%$, mas tem precisão de $0,06 \%$ para o CO.

Assim, pode-se concluir que a variável "temperatura" é um dos itens mais críticos quanto à emissão de $\mathrm{CO}$.

O gráfico 4.2.15 ilustra a relação entre a emissão em gramas de CO pela velocidade no percurso.

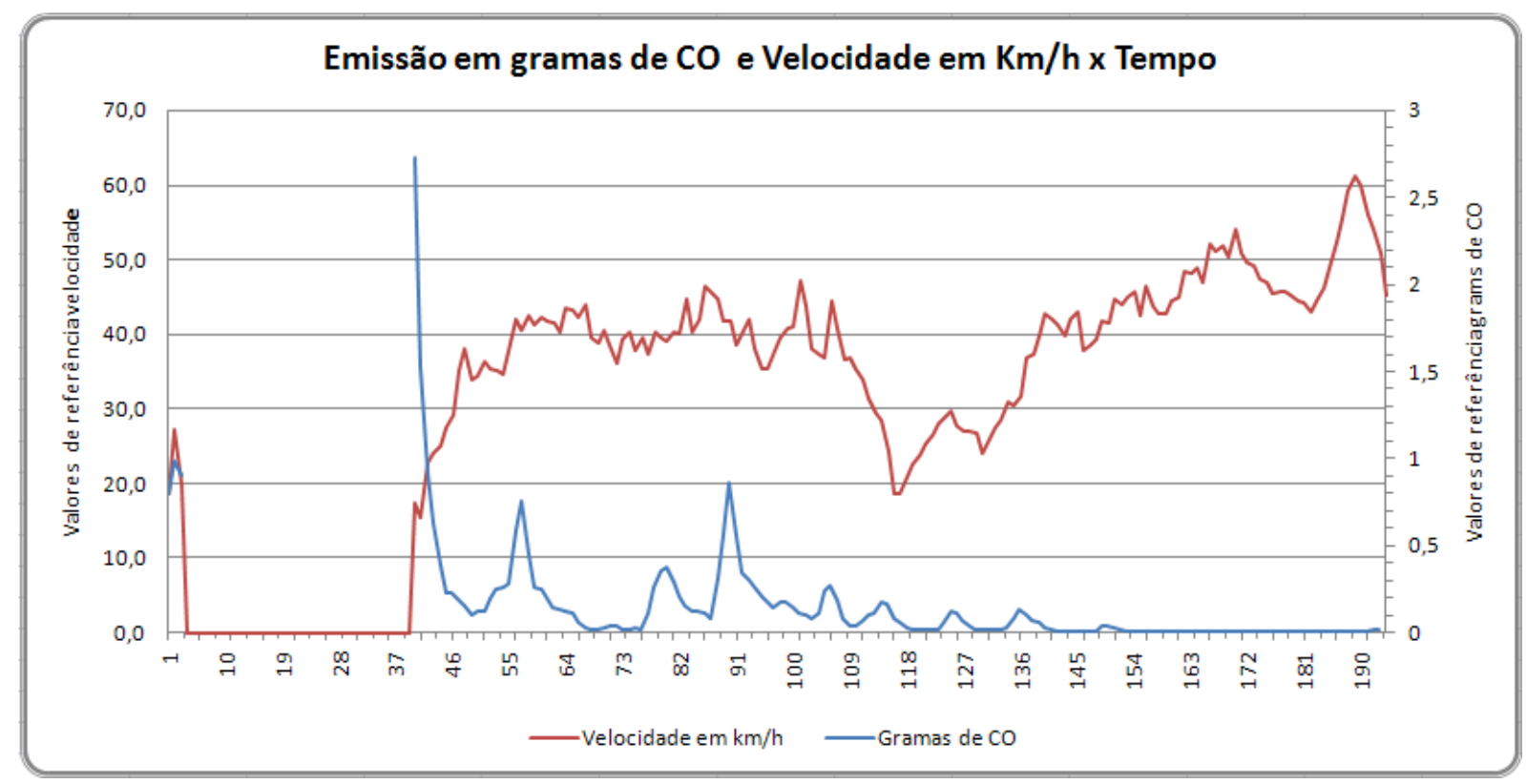

Gráfico 4.2.15 - Gramas CO e Velocidade x Tempo

Inicialmente, em razão da velocidade zero, a quantidade de gramas de $\mathrm{CO}$ emitida não foi mensurada.

No aclive (aproximadamente segundos 37-140), é possível notar que, mesmo com velocidade relativamente constante, em torno de $40 \mathrm{~km} / \mathrm{h}$, houve vários picos na emissão de $\mathrm{CO}$ em gramas, o que se explica pelas condições do aclive. Os picos que se observam acerca dos segundos 55, 80 e 91 se explicam pela troca de marchas (reduções ou acelerações).

Ao final do percurso (após o segundo 141), a quantidade de gramas de $\mathrm{CO}$ emitida se estabiliza próxima de zero, em virtude do declive, visto que, neste ensaio, o motor sempre está aquecido. Assim, ao lado da temperatura, a inclinação da via se mostra relevante para o estudo da emissão de CO enquanto 
que a velocidade isoladamente não possui uma relação confiável com a emissão em gramas de CO.

Neste trecho, verifica-se que não houve qualquer parada (não há velocidade zero, a não ser no início). Esse fato favorece uma continuidade na coleta dos dados. Em comparação com os dados obtidos com motor frio, em que houve mais paradas (cf. gráfico 4.2.2), a emissão de CO é maior, tanto em função da baixa temperatura do motor, quanto em função das paradas.

O gráfico 4.2.16 mostra a relação entre a emissão em gramas de CO pelo perfil vertical do trecho ensaiado, ilustrando sua inclinação.

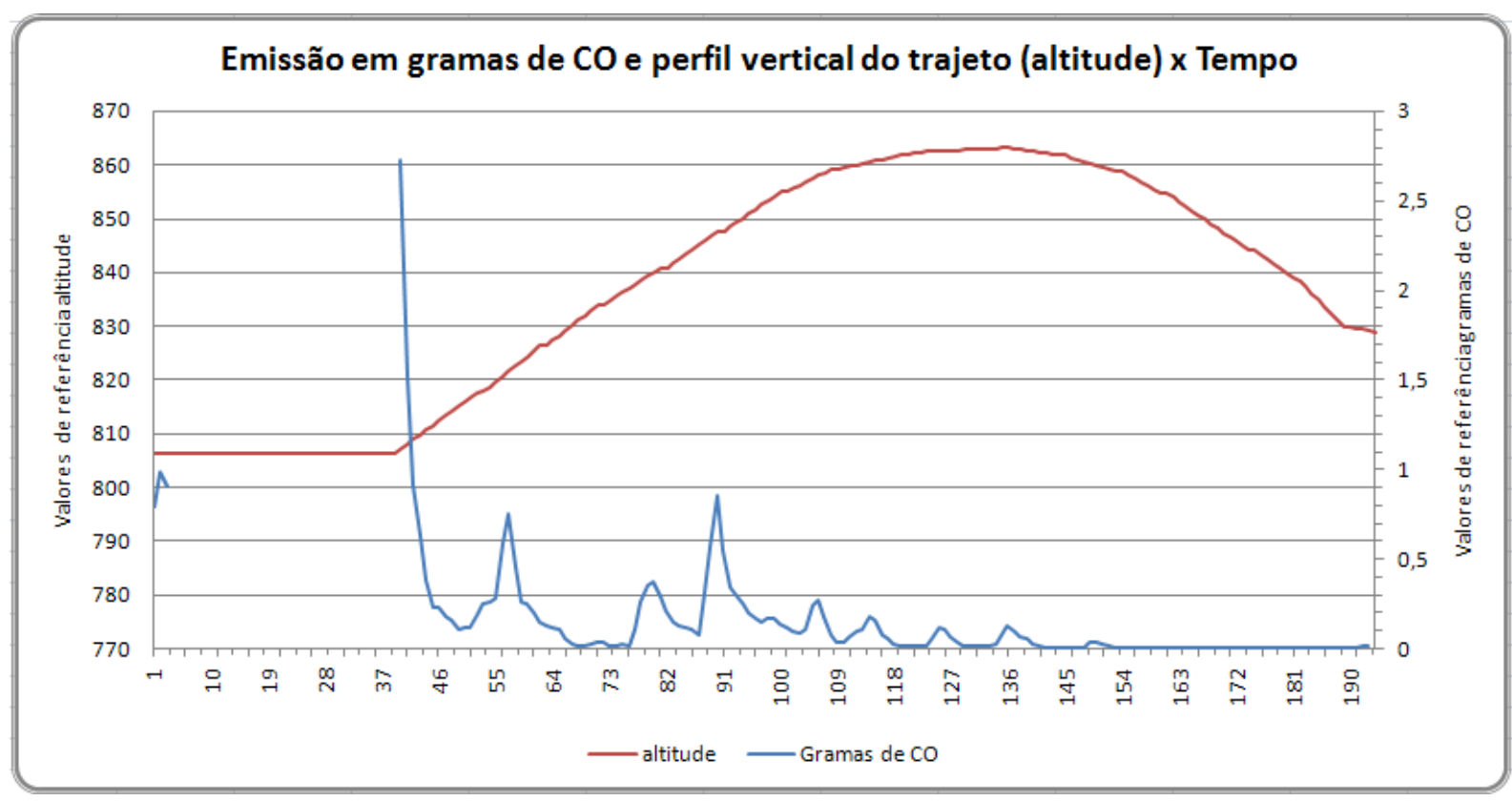

Gráfico 4.2.16 - Gramas CO e Altitude x Tempo

Com o motor quente, verificam-se vários picos na emissão de $\mathrm{CO}$ em gramas com relação ao aclive da via. No declive (a partir de cerca do segundo 142), nota-se certa estabilidade na emissão de CO.

Com o motor frio (cf. gráfico 4.2.3), a análise deve-se centrar a partir do segundo 290 (aproximadamente), onde começa o aclive compatível com o início do ensaio quente. Os picos de emissão de CO são mais altos e demoram mais a cair, mantendo-se quase que o período todo acima de $0,4 \mathrm{~g}$ (a queda a quase zero se refere ao período em que o veículo esteve parado e, portanto, merece ser desconsiderada, visto não refletir a realidade, conforme já discutido).

Comparando-se com os dados obtidos com o motor frio (cf. gráfico 4.2.3), percebe-se que a emissão com o motor quente é muito menor. Essas 
informações ficam muito mais visíveis comparando-se os dados apresentados nas tabelas 5.1.3 a 5.1.6:

A tabela 4.2.2 compara os dados de emissão em gramas de CO obtidos nos trechos 3 e 4 , com motor frio e quente.

Tabela 4.2.2 - Comparação entre os níveis de CO emitidos entre os trecho 3 e 4

\begin{tabular}{|c|c|c|}
\hline CO emitido em g & Motor frio & Motor quente \\
\hline Trecho 3 & 51,7 & 20,4 \\
\hline Trecho 4 & 3,6 & 1,8 \\
\hline
\end{tabular}

A partir desses dados, pode-se afirmar que a emissão de CO se reduz conforme o motor está aquecido. Essas análises levam à conclusão de que a associação de aclive acentuado com motor frio gera a situação mais desfavorável para a emissão de $\mathrm{CO}$ e que o motor aquecido em declive acentuado descreve a situação de menor emissão de $\mathrm{CO}$ em gramas.

O gráfico 4.2.17 ilustra a relação entre a emissão em gramas de CO pela distância percorrida.

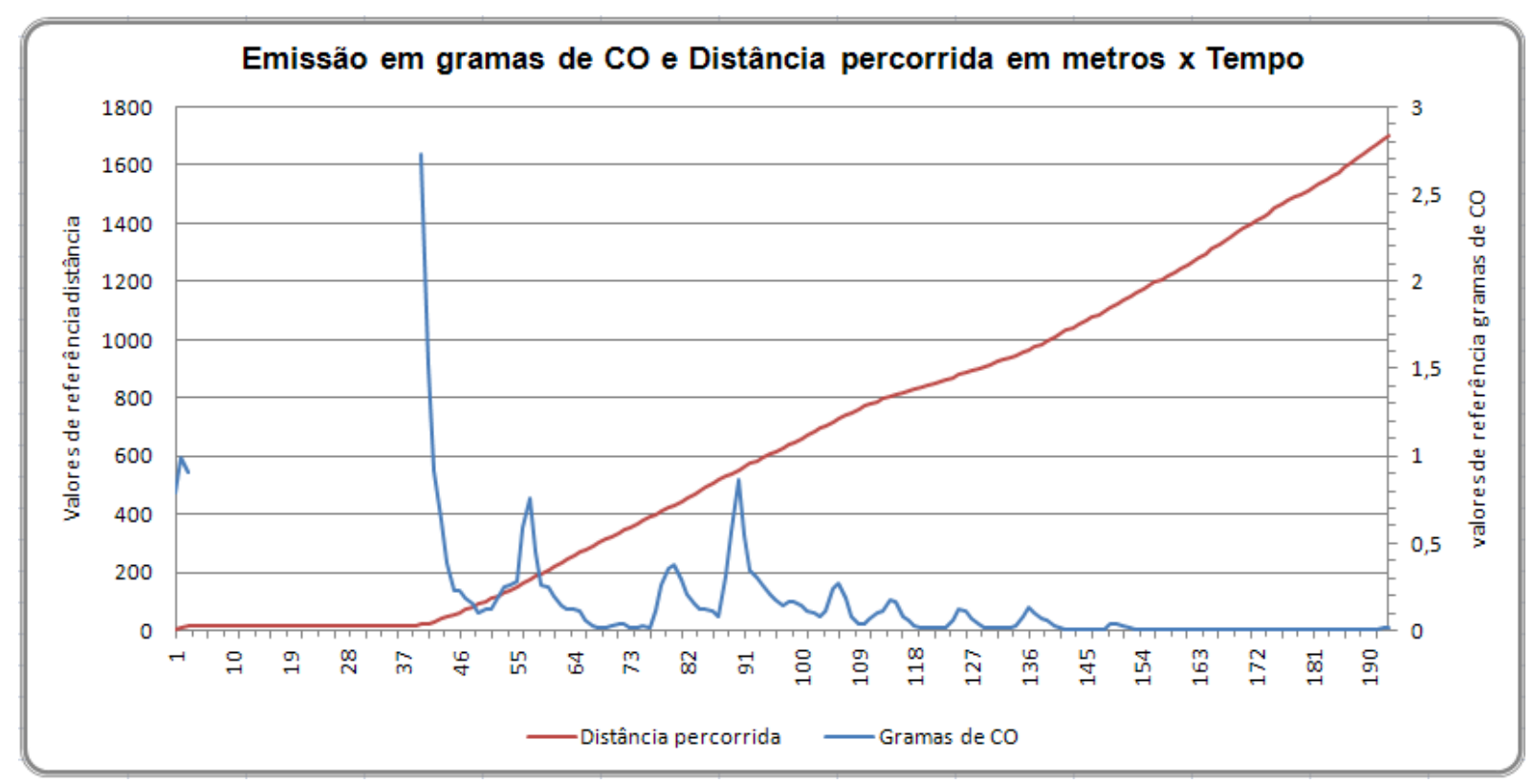

Gráfico 4.2.17 - Gramas CO e Distância x Tempo

Com o motor quente, verifica-se que a emissão de CO diminui e se estabiliza, ao final do percurso, em razão do declive. No início do gráfico, há 
uma alta na emissão de gramas de $\mathrm{CO}$, já que o veículo está iniciando a manobra de posicionamento para o início do ensaio. Depois ocorre uma queda sensível, a emissão de gramas de $\mathrm{CO}$ aproximando-se de zero, até por volta do segundo 38 , momento em que o veículo está parado no semáforo, quando se percebe um aumento sensível da emissão de gramas de CO. Até por volta do segundo 110 , à emissão de $\mathrm{CO}$ é bastante irregular, com vários picos, em virtude do aclive e, a partir do segundo 140, a emissão de CO se estabiliza em níveis próximos a zero, em razão do declive da via.

Percebe-se, portanto, que a relação entre a distância percorrida e os níveis de emissão de CO tanto com o motor frio quanto com o motor quente não é significativa. Em regra, a distância não importa. O que ocorre é que, com a distância percorrida, ocorre o aquecimento do motor, este fator sim relevante para a análise proposta, conforme já discutido.

O gráfico 4.2.18 ilustra a relação entre a emissão em gramas de CO pelo aquecimento do motor.

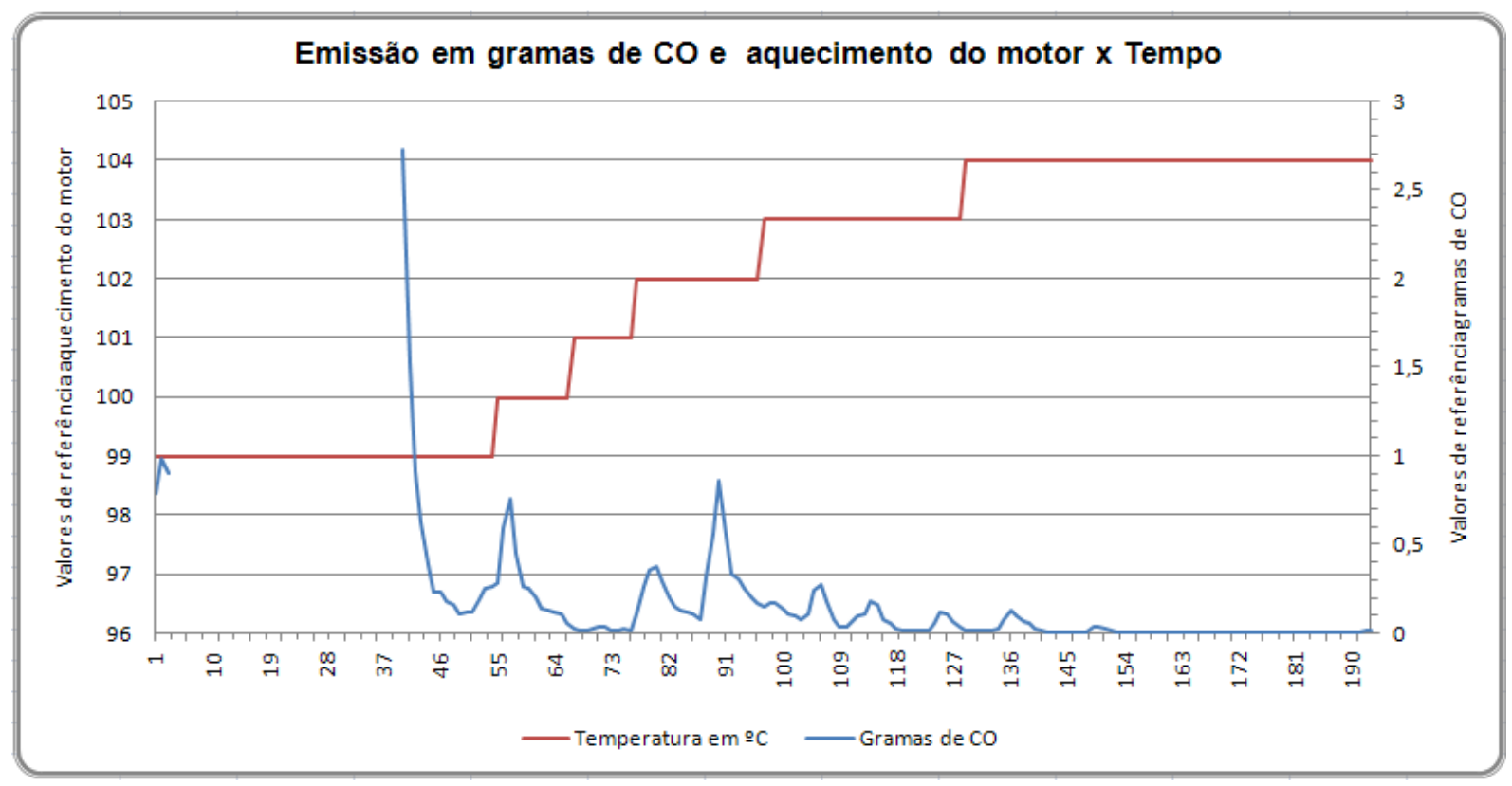

Gráfico 4.2.18 - Gramas CO e Aquecimento do motor x Tempo

Verifica-se que, com o motor já aquecido, a quantidade de gramas de $\mathrm{CO}$ emitida não varia muito em função da temperatura. Há picos na emissão, que não podem ser explicados pela temperatura do motor, que se manteve 
quase constante, como ocorre quando o motor está frio. Esses picos se explicam por outros fatores, como a inclinação da via e aceleração do motor.

É importante notar que a temperatura influencia no resultado dos testes apenas quanto ao fator quente/frio. Uma vez estando aquecido o motor, não há variação da emissão de $\mathrm{CO}$ exclusivamente em função da temperatura outros dados, então, passam a ter maior relevância. Com o motor frio, a temperatura passa a ser o item de maior influência (cf. gráfico 4.2.6).

O gráfico 4.2.19 ilustra a relação entre a emissão em gramas de CO pelo consumo em gramas de gasolina.

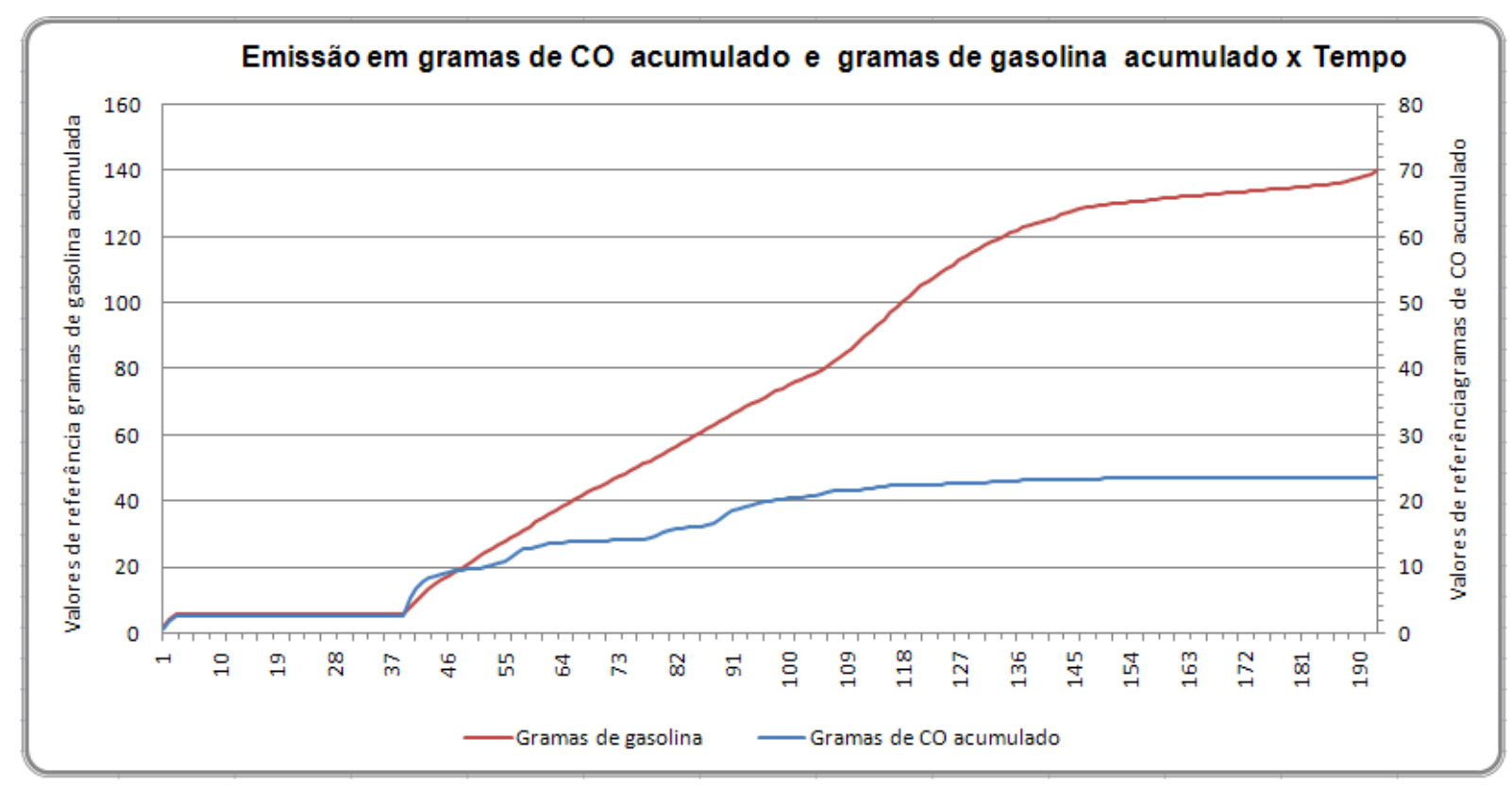

Gráfico 5.2.19 - Gramas CO e Gramas gasolina x Tempo

A quantidade de gramas de CO acumulada, inicialmente, até por volta do segundo 41 , é muito semelhante à quantidade de gramas de gasolina acumulada, visto que o deslocamento do veículo é zero, conforme já explicitado. Após esse período, quando o veículo de fato entra em movimento, ou seja, com o aumento da velocidade, ocorre um aumento progressivo na quantidade de gramas de gasolina acumulada enquanto que a quantidade de gramas de $\mathrm{CO}$ acumulada aumenta muito pouco. As linhas ficam quase paralelas, isto é, a eficiência da combustão chega ao seu limite para este percurso.

Até o final do percurso, há uma grande diferença entre ambos, o que também ocorreu com o motor frio. Entretanto, nos dados obtidos com o motor 
frio, a diferença entre as duas variáveis começa a aumentar sensivelmente após o segundo 300 (aproximadamente), enquanto que a diferença começa a aumentar, com o motor quente, logo após o deslocamento (segundo 40).

Esse distanciamento entre ambos os dados demonstra a maior eficiência do motor. Conforme levantado na análise para o motor frio (cf. gráfico 4.2.7), o motor se torna mais eficiente conforme está mais aquecido.

\subsubsection{Análise da emissão de HC com o motor quente}

Os gráficos relacionam a emissão de $\mathrm{HC}$ em gramas com as outras variáveis relevantes medidas durante o ensaio: porcentagem de $\mathrm{HC}$, velocidade, inclinação da via, distância percorrida, temperatura do motor e gramas de gasolina acumulada.

Entre os segundos 1 e 37 , o veículo saiu da vaga em que estava estacionado para que os aparelhos fossem ligados e parou no semáforo. Apenas a partir do segundo 37 é que se inicia o aclive que se pretende observar mais atentamente a partir dos gráficos desta sessão.

O gráfico 4.2.20 ilustra a comparação entre a emissão em gramas de $\mathrm{HC}$ pela sua porcentagem.

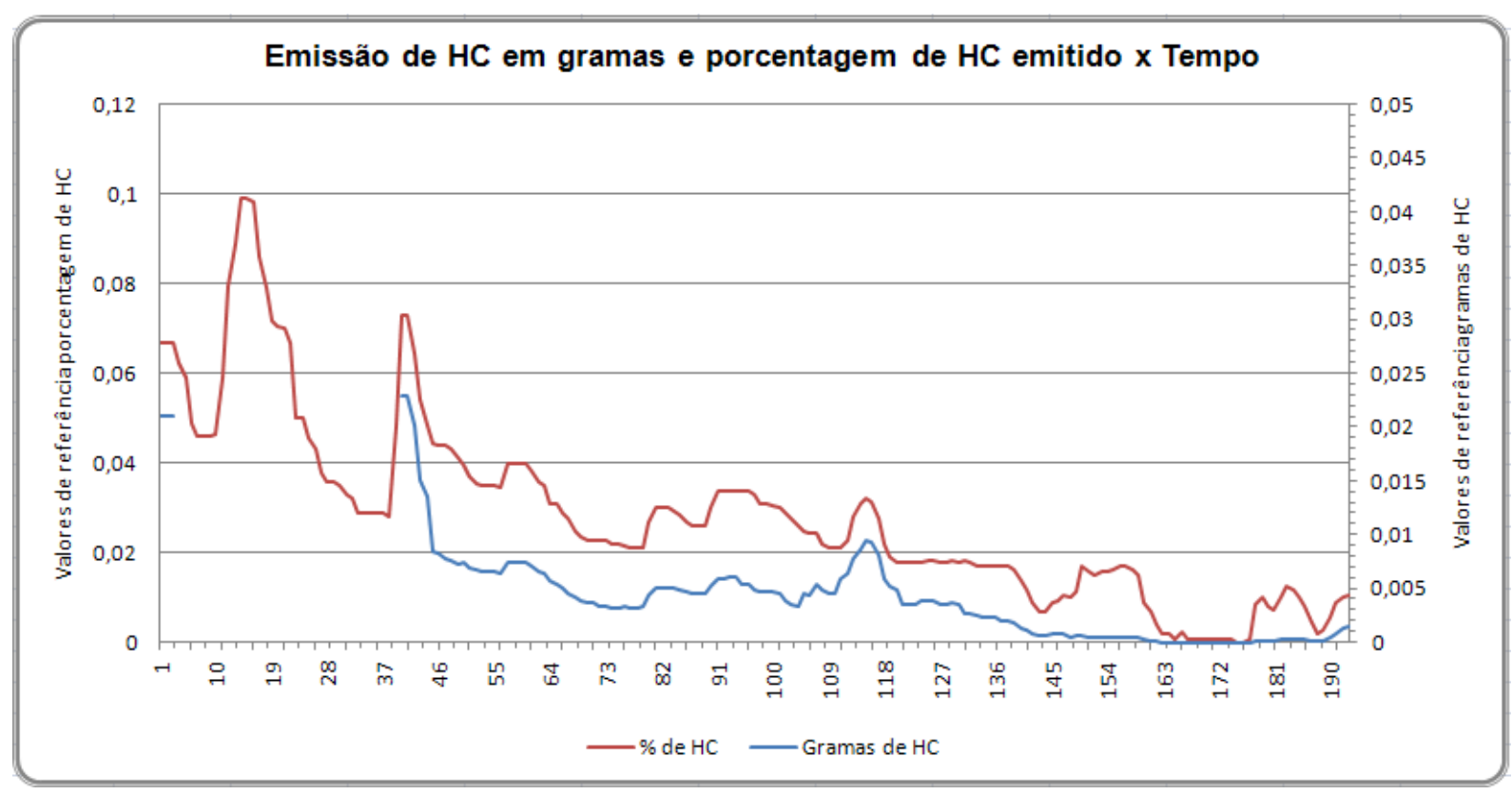

Gráfico 4.2.20 - Gramas HC e \% HC x Tempo 
No início do aclive (por volta do segundo 37), há um pico na emissão de $\mathrm{HC}$, tanto em gramas quanto em porcentagem, o que se explica justamente pela inclinação do terreno. Ou seja: mesmo com o motor aquecido, situação em que, em regra, a emissão de $\mathrm{HC}$ se torna mais regular, há um aumento sensível nessa emissão em razão da inclinação do terreno e do consequente esforço do motor.

Comparada com a emissão de $\mathrm{CO}$, a emissão de $\mathrm{HC}$ é muito mais reduzida. Durante todo o percurso, a emissão em gramas acompanha a porcentagem emitida, com exceção de um trecho próximo ao final (segundos 162 a 176, aproximadamente), em razão do declive do terreno, que exigiu menos esforço do motor.

Cotejando-se os dados obtidos com o motor frio (cf. gráfico 4.2.8), o pico inicial de emissão de $\mathrm{HC}$ chega a cerca de $1,2 \mathrm{~g}$, enquanto que com 0 motor quente esse pico é de cerca de 0,02g. Ou seja: a emissão de HC está diretamente relacionada com a temperatura do motor, principalmente na fase de arranque.

O gráfico 4.2.21 ilustra a relação entre a emissão em gramas de $\mathrm{HC}$ pela velocidade.

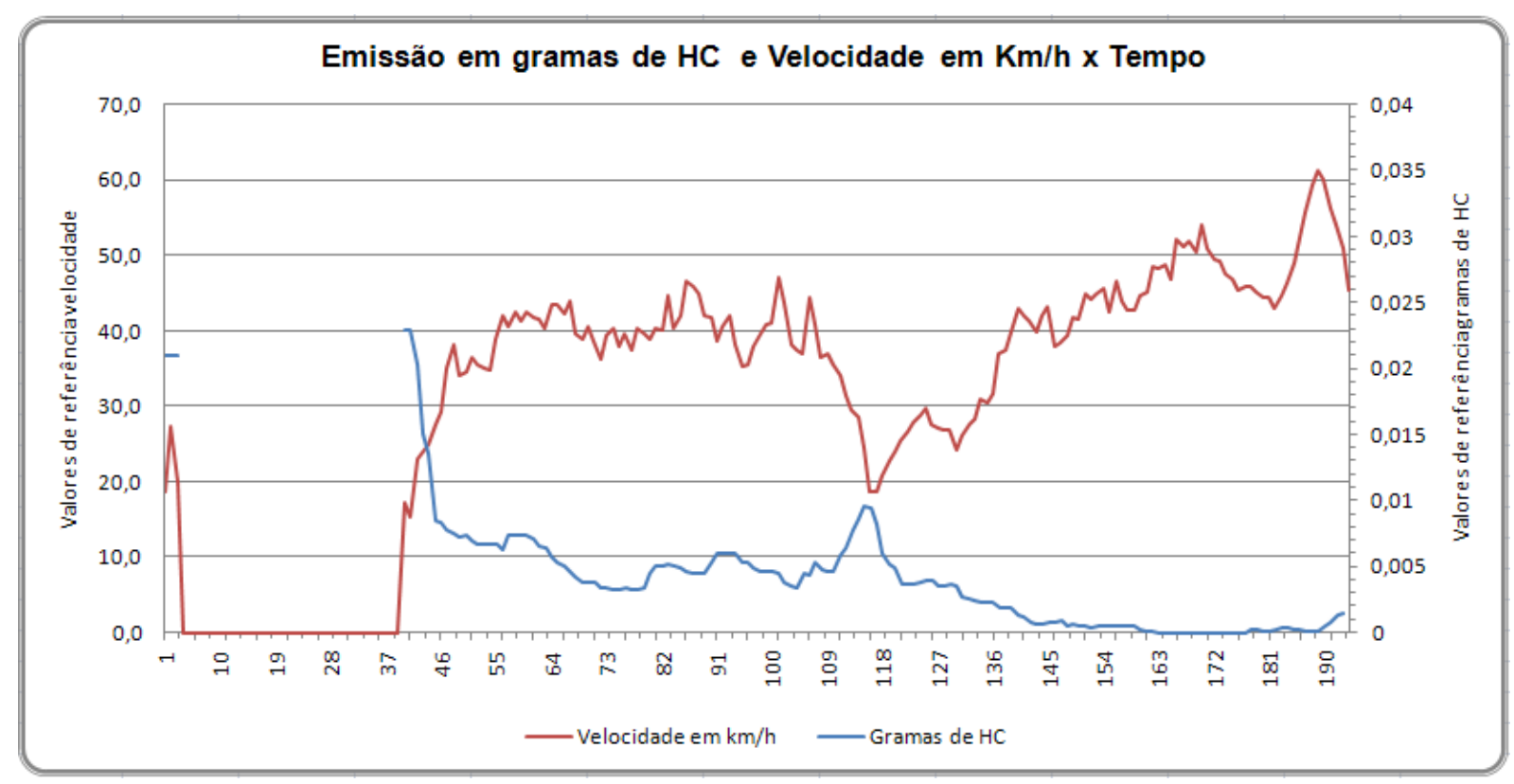

Gráfico 4.2.21 - Gramas HC e Velocidade x Tempo 
O aumento da emissão de $\mathrm{HC}$ acompanha o aumento da velocidade, principalmente no início do aclive. No restante do ensaio, a variação de HC não está relacionada apenas com a velocidade, como se observa principalmente após, aproximadamente, o segundo 134, momento em que se inicia o declive da via. Mesmo com o aumento da velocidade, ocorre redução na emissão de HC nessas condições.

Assim, modelos que se baseiam unicamente na mensuração da velocidade não se mostram confiáveis, visto que outras variáveis, como a temperatura do motor e inclinação da via se mostraram influentes para a emissão de $\mathrm{HC}$.

Comparando-se com os dados obtidos com o motor frio (cf. gráfico 4.2.9), o que deve ser feito após o segundo 292 (início do trecho 3), é possível verificar que não há uma ligação direta entre a velocidade desenvolvida em um e em outro ensaio. A relação se estabelece, na verdade, com o esforço do motor para vencer o aclive da via ou com o alívio para percorrer o declive.

O gráfico 4.2.22 mostra a relação entre a emissão em gramas de HC pelo perfil vertical do terreno, ilustrando sua inclinação.

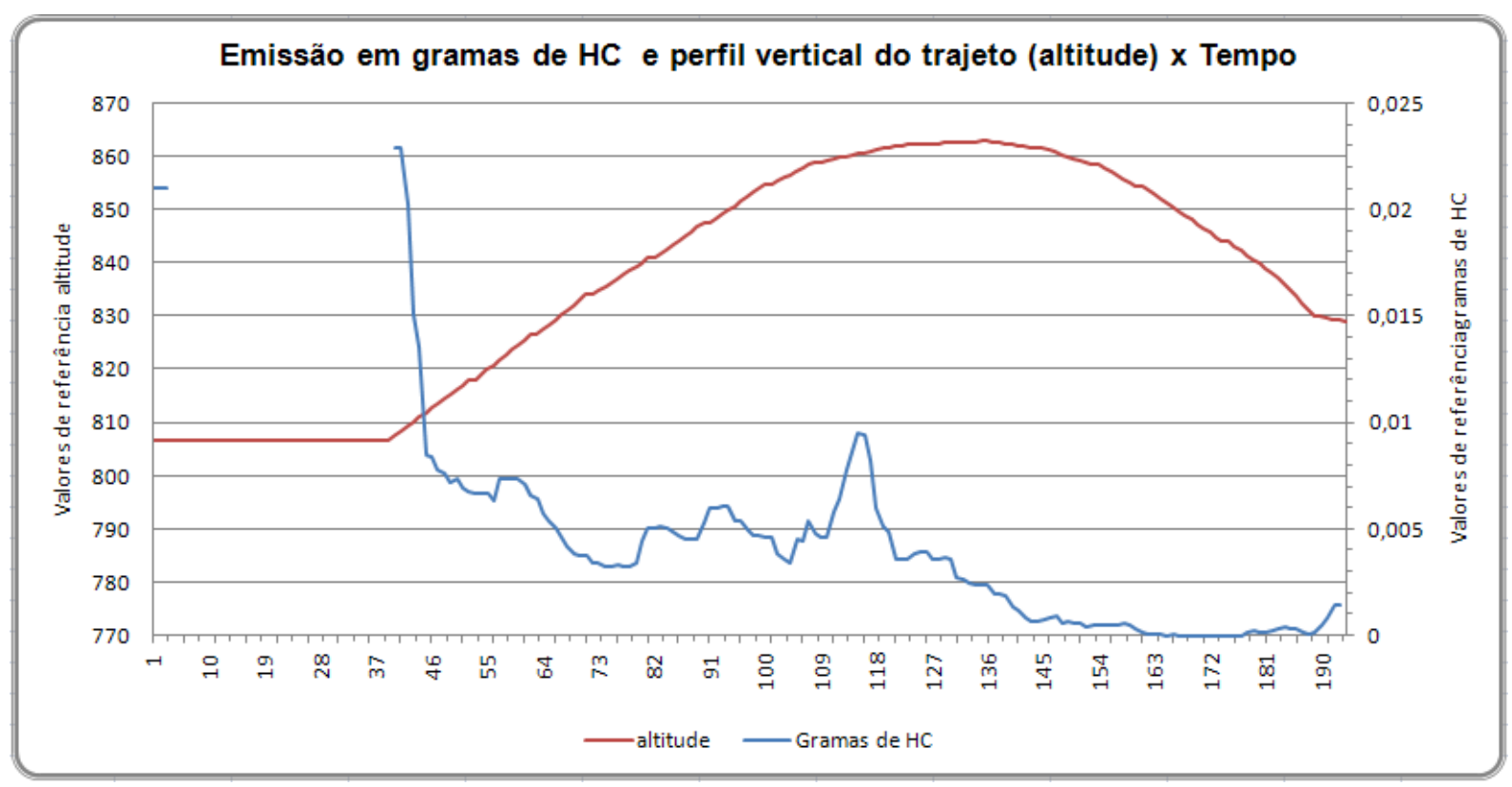

Gráfico 4.2.22 - Gramas HC e Altitude x Tempo

A emissão de $\mathrm{HC}$, apesar de se mostrar constantemente baixa durante todo o ensaio (visto que o motor está aquecido), tem um aumento relevante, 
com picos, no aclive e, a partir do início do declive (por volta do segundo 130), começa a reduzir e a se estabilizar, com exceção do momento final, o que se explica, como citado, pela manobra realizada para estacionar o veículo.

Comparando-se com os dados obtidos com o motor frio (cf. gráfico 4.2.10), percebe-se que a emissão com o motor quente é muito menor. Essas informações ficam muito mais visíveis comparando-se os dados apresentados nas tabelas 4.1.3 a 4.1.5:

A tabela 4.2.3 compara os dados de emissão em gramas de $\mathrm{HC}$ obtidos nos trechos 3 e 4, com motor frio e com o motor quente.

Tabela 4.2.3 - Comparação entre os níveis de HC emitidos entre os trecho 3 e 4

\begin{tabular}{|c|c|c|}
\hline HC emitido em g & Motor frio & Motor quente \\
\hline Trecho 3 & 1,9 & 0,6 \\
\hline Trecho 4 & 0,2 & 0,06 \\
\hline
\end{tabular}

A partir desses dados, pode-se afirmar tanto que a emissão de $\mathrm{HC}$ é muito reduzida quando o motor está aquecido para um mesmo trecho, tanto que a emissão é muito menor em trechos de declive. Ou seja, a emissão de HC é menor quando o motor está aquecido e em declive. Assim, mais uma vez, comprovase que as variáveis mais relevantes nos ensaios realizados são a temperatura e a inclinação do terreno.

O gráfico 4.2.23 ilustra a relação entre a emissão em gramas de HC pela distância percorrida. 


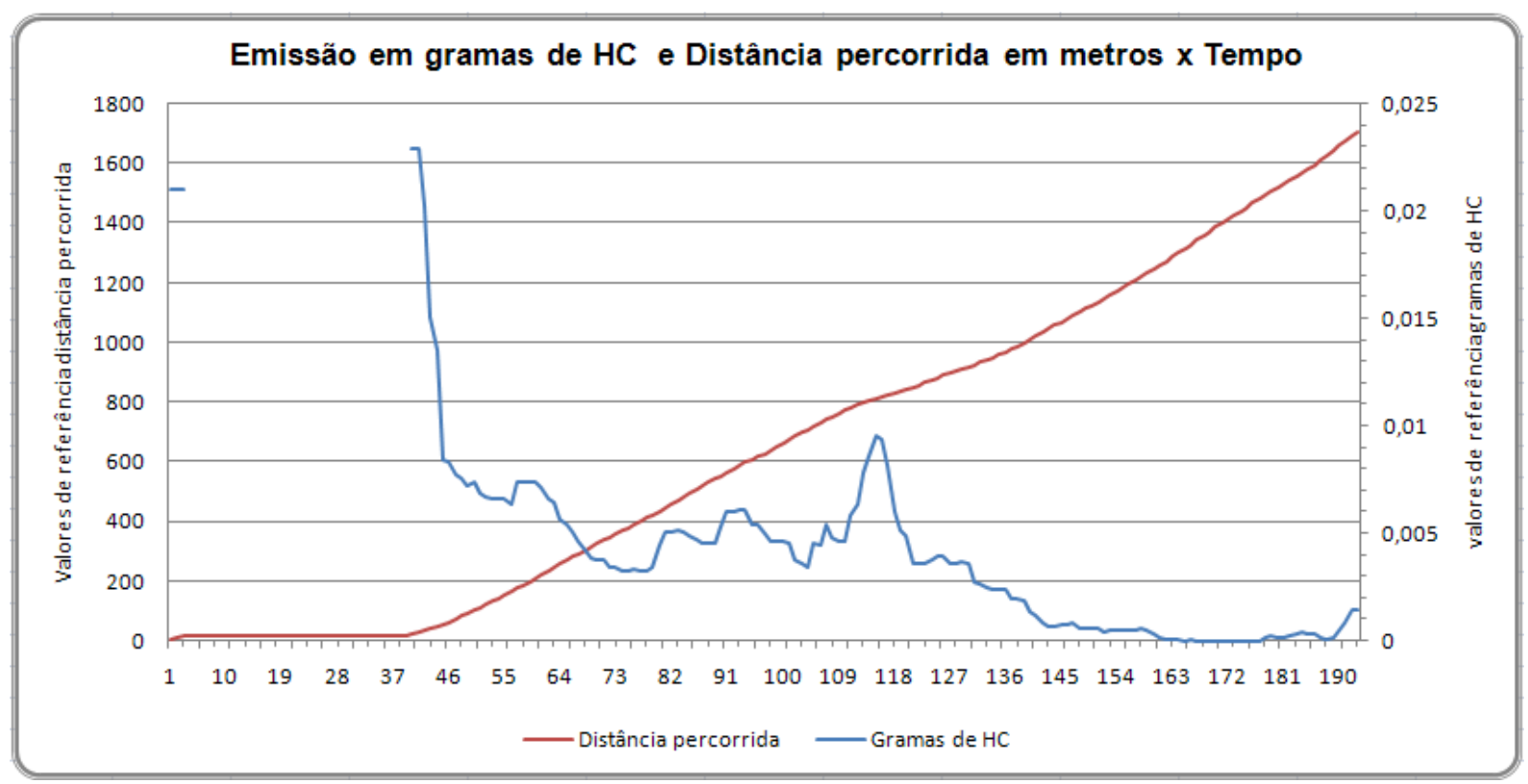

Gráfico 4.2.23 - Gramas HC e Distância x Tempo

Como o motor está aquecido, portanto, a distância percorrida mostra pouca ou quase nenhuma influência na emissão de $\mathrm{HC}$ em gramas, visto que, como já ressaltado, outros fatores se mostram mais relevantes (temperatura do motor e inclinação da via).

O gráfico 4.2.24 ilustra a relação entre a emissão em gramas de $\mathrm{HC}$ pelo aquecimento do motor.

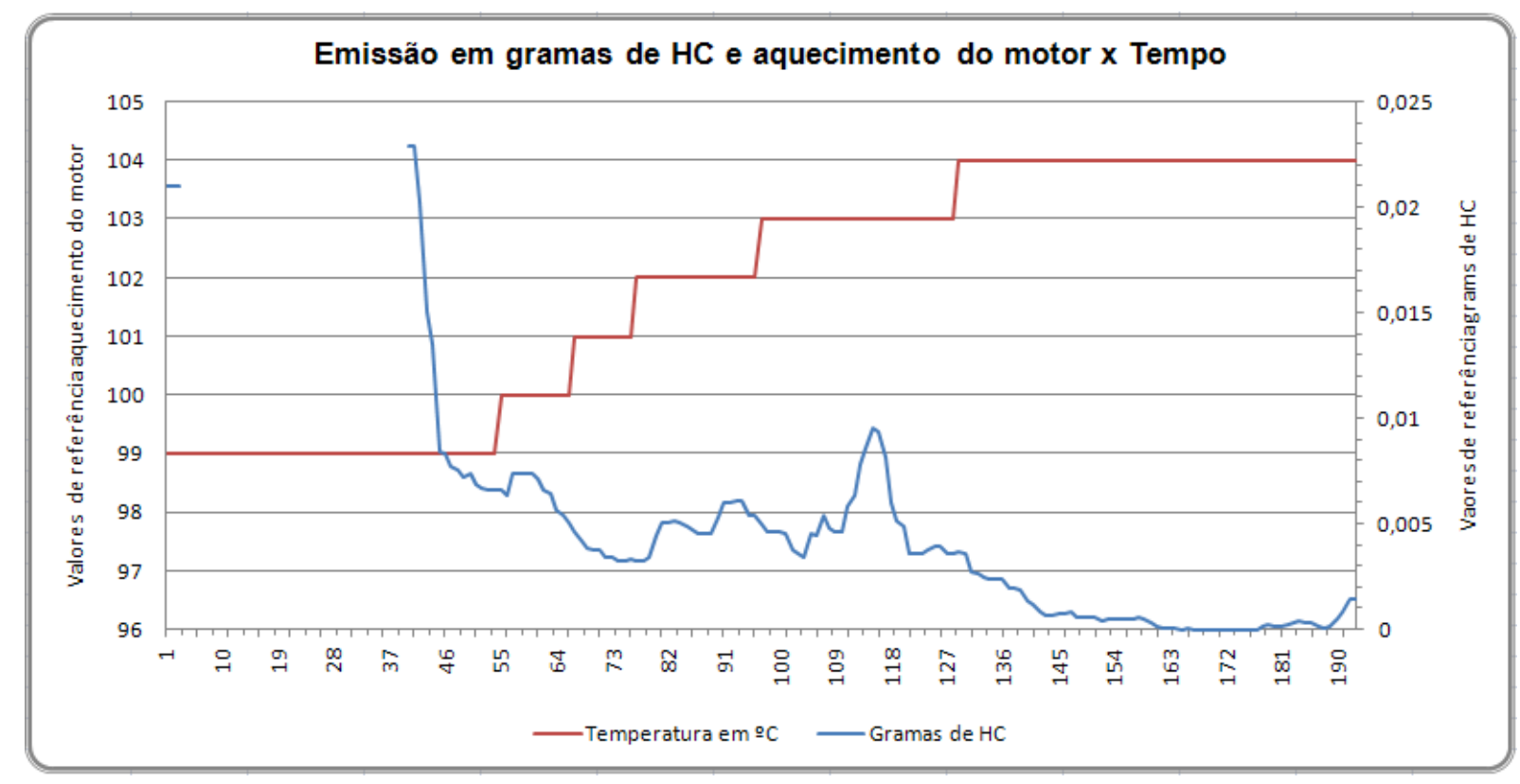

Gráfico 4.2.24 - Gramas HC e Aquecimento do motor x Tempo 
Tendo em vista que o motor já estava aquecido no início da medição dos dados, esta se estabilizou em torno de $100^{\circ} \mathrm{C}$ e não influenciou diretamente as alterações na emissão de HC.

Assim como ocorreu com o motor frio (cf. gráfico 4.2.12), houve um pico inicial na emissão, apesar de muito menor que aquele. Pode-se concluir, portanto, que o arranque inicial do motor, que exige maior esforço, provoca uma maior emissão de $\mathrm{HC}$.

O gráfico 4.2.25 ilustra a relação entre a emissão em gramas de $\mathrm{HC}$ pelo consumo em gramas de gasolina.

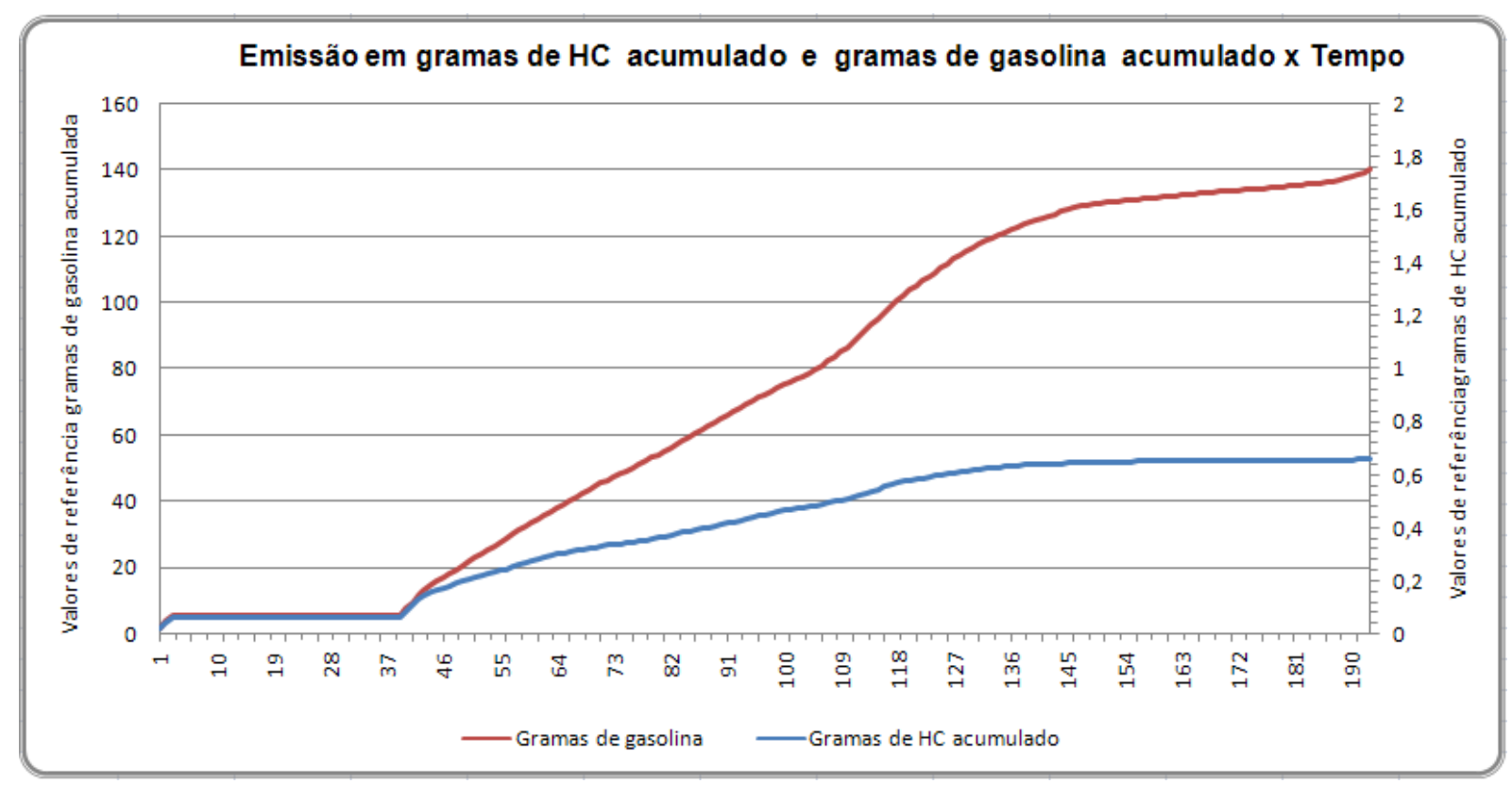

Gráfico 4.2.25 - Gramas HC e Gramas gasolina x Tempo

Com o motor aquecido, a eficiência da queima da gasolina se mostrou mais próxima do estequiométrico, ou seja, há pouca emissão de HC relativamente. Com relação aos dados obtidos com o motor frio (cf. gráfico 4.2.13), percebe-se que a emissão é muito maior. Assim, a temperatura mostra-se um fator relevante para a medição da emissão de HC.

\subsubsection{Análise da emissão de CO com o motor quente no trecho 5}

Primeiramente, deve-se lembrar que este trecho foi ensaiado tendo em vista sua potencial semelhança aos modelos ideais de emissão de gases, 
ou seja, em razão de ter poucas paradas e permitir o desenvolvimento de velocidade relativamente constante e próxima de $50 \mathrm{~km} / \mathrm{h}$.

Os gráficos relacionam a emissão de $\mathrm{CO}$ em gramas com as outras variáveis relevantes medidas durante o ensaio: porcentagem de $\mathrm{CO}$, velocidade, inclinação da via, distância percorrida, temperatura do motor e gramas de gasolina acumulada.

O gráfico 4.2.26 ilustra a comparação entre a emissão em gramas de $\mathrm{CO}$ pela porcentagem de $\mathrm{CO}$ emitido.

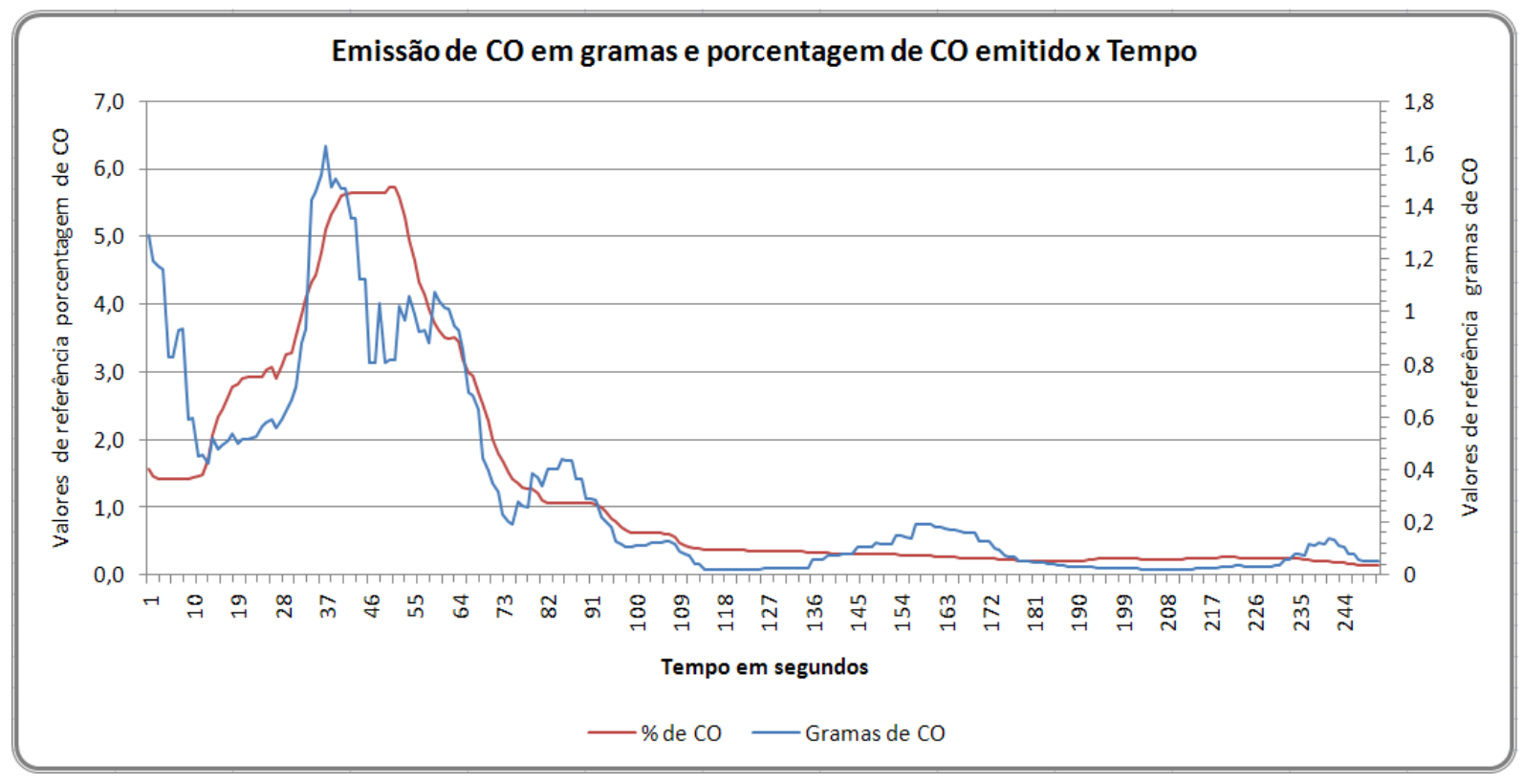

Gráfico 4.2.26 - Gramas CO e \% CO x Tempo

Embora pareça ser alta, a emissão de $\mathrm{CO}$ em gramas, neste caso, é baixa, o que não acontece com a porcentagem de $\mathrm{CO}$ emitido, que é relativamente alta, principalmente nos momentos iniciais. Note-se que nos outros gráficos semelhantes (ensaios para o motor frio - gráfico 4.2.1 - e para o motor quente - gráfico 4.2.17). O esforço inicial para o arranque do veículo é extremamente relevante para a quantidade de $\mathrm{CO}$ emitida, tanto que, de acordo com o gráfico, percebe-se maior variação justamente no trecho inicial, que envolve a saída do veículo e um trecho com maior quantidade de redução de velocidade (entrada da USP, por exemplo), como se verá na comparação feita no próximo gráfico. 
Por outro lado, existe uma relação evidente entre a emissão de $\mathrm{CO}$ em gramas e sua porcentagem; as linhas do gráfico são próximas, exceto no momento do arranque.

O gráfico 4.2.27 ilustra a relação entre a emissão em gramas de CO pela velocidade do veículo.

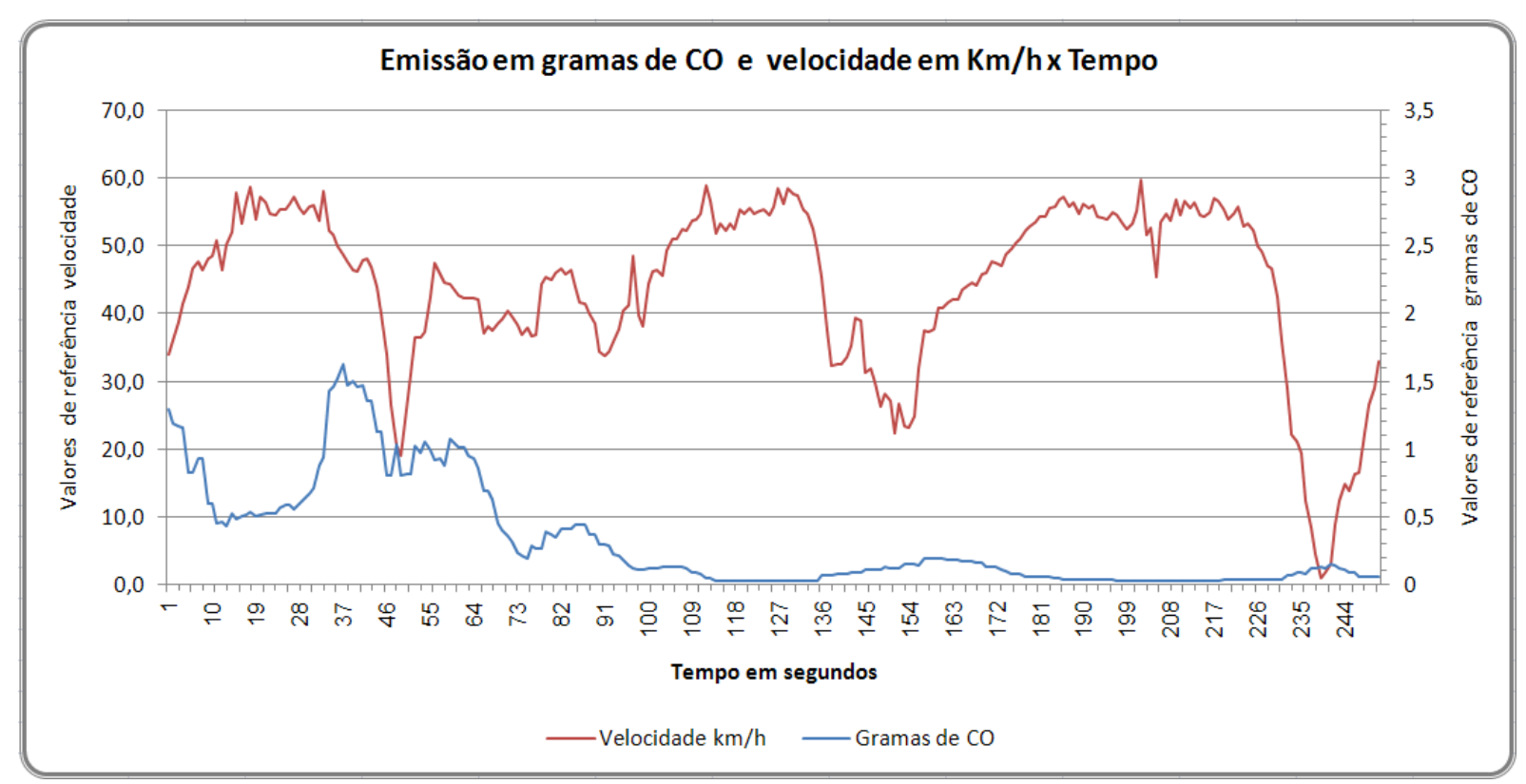

Gráfico 4.2.27 - Gramas CO e Velocidade x Tempo

A velocidade se manteve relativamente constante e elevada, exceto em alguns momentos. O único momento em que o veículo parou foi ao final do ensaio. Outro ponto relevante é a grande queda de velocidade por volta do segundo 45, ou seja, ainda no início do percurso, em que há, no mesmo período, um aumento relevante na emissão de CO. Essa redução se deve ao trânsito no dia do ensaio e não ocorreu sempre da mesma forma, obviamente. Houve ensaios em que o veículo esteve sem movimento durante alguns momentos, devido à existência de um semáforo no percurso.

Assim, pode-se concluir que a relação entre a emissão de $\mathrm{CO}$ e o aumento de velocidade, não possuem uma ligação direta, sendo que a influência da temperatura do motor e a inclinação da via são as mais relevantes.

O gráfico 4.2.28 mostra a relação entre a emissão em gramas de CO pelo perfil vertical da via, ilustrando sua inclinação. 


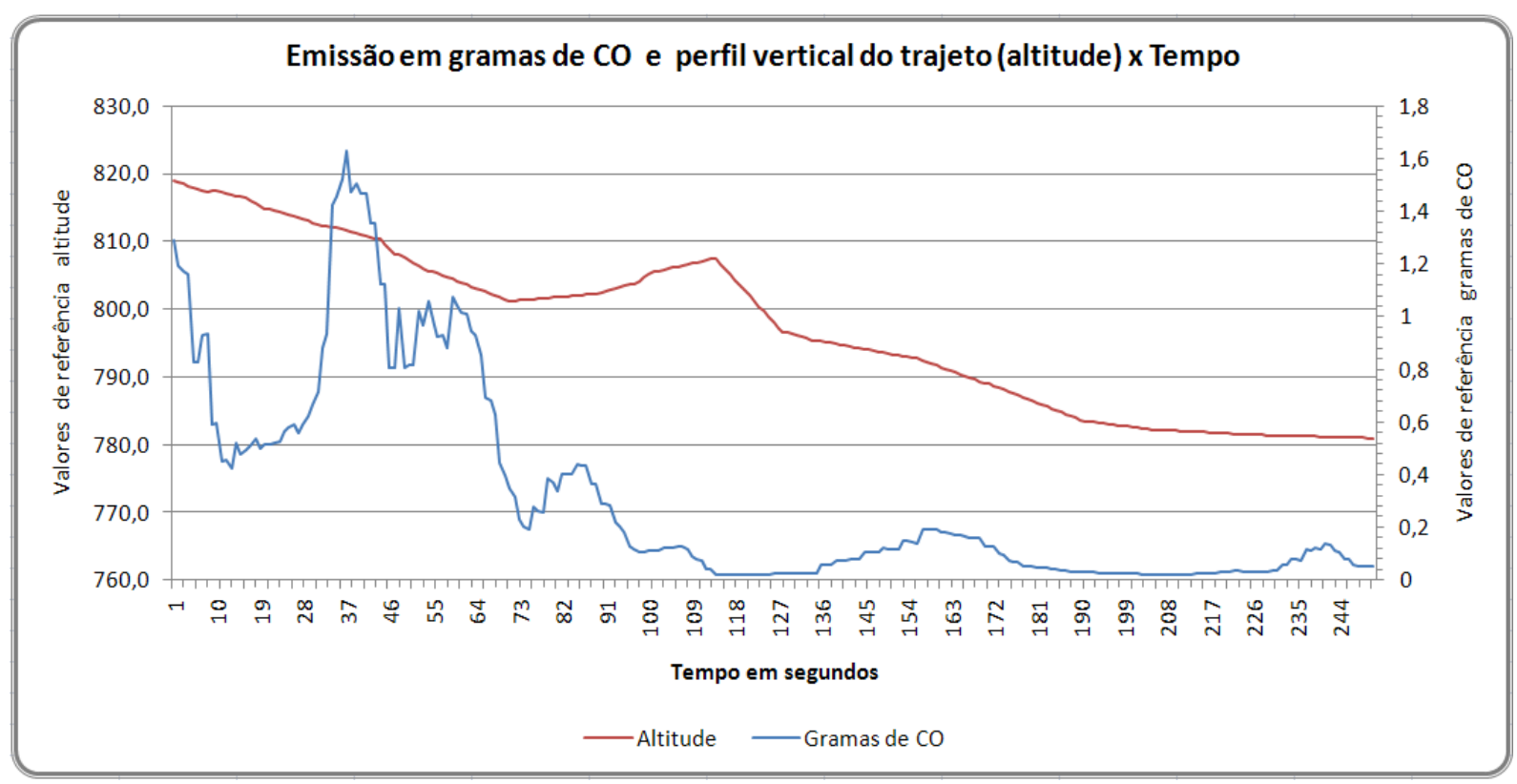

Gráfico 4.2.28 - Gramas CO e Altitude x Tempo

Tendo em vista que este percurso ocorreu em relevo mais baixo que os outros ensaios já analisados, foram reduzidos $750 \mathrm{~m}$ do valor absoluto da altitude e ocorreu a divisão por 35 para que os valores ficassem comparáveis com a emissão de $\mathrm{CO}$ em gramas, que foi multiplicada por 2.

Neste trecho, quase não há aclives. Há uma pequena elevação por volta dos segundos 82-118, acompanhada por um pequeno aumento na emissão de CO. Percebe-se que a emissão de CO no início se mostra bastante irregular, tendo em vista que o motor ainda não está tão aquecido, como se verá. Com o aumento da temperatura do motor e com o trecho mais regular, livre de obstáculos, no decorrer do ensaio, a emissão de CO se reduz e se torna mais estável.

O gráfico 4.2.29 mostra a relação entre a emissão em gramas de $\mathrm{CO}$ pelo aquecimento do motor. 


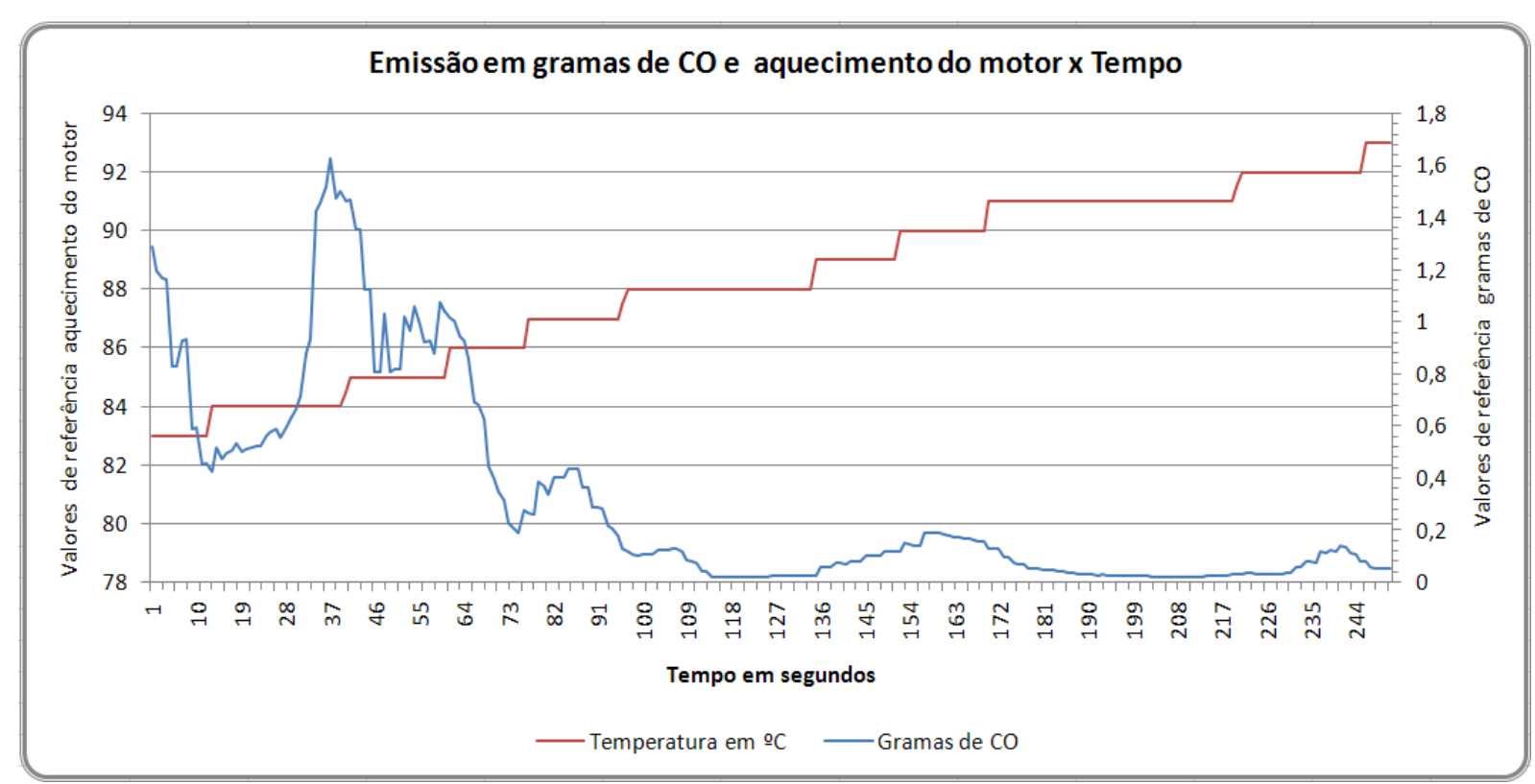

Gráfico 4.2.29 - Gramas CO e Aquecimento do motor x Tempo

O motor não estava tão aquecido como deveria no início deste ensaio, o que não ocorreu em todos os ensaios. Houve outros ensaios em que o motor estava mais aquecido, com a temperatura mais estabilizada. Assim, a emissão de CO no início do percurso se mostrou mais regular em outros ensaios que neste. Neste caso, especificamente, a irregularidade inicial na emissão de CO explica-se pela conjugação do arranque do veículo com reduções de velocidade devidas ao movimento do trânsito com a temperatura do motor fora do ideal.

O gráfico 4.2.30 mostra a relação entre a emissão em gramas de CO pelo consumo de gasolina em gramas no percurso. 


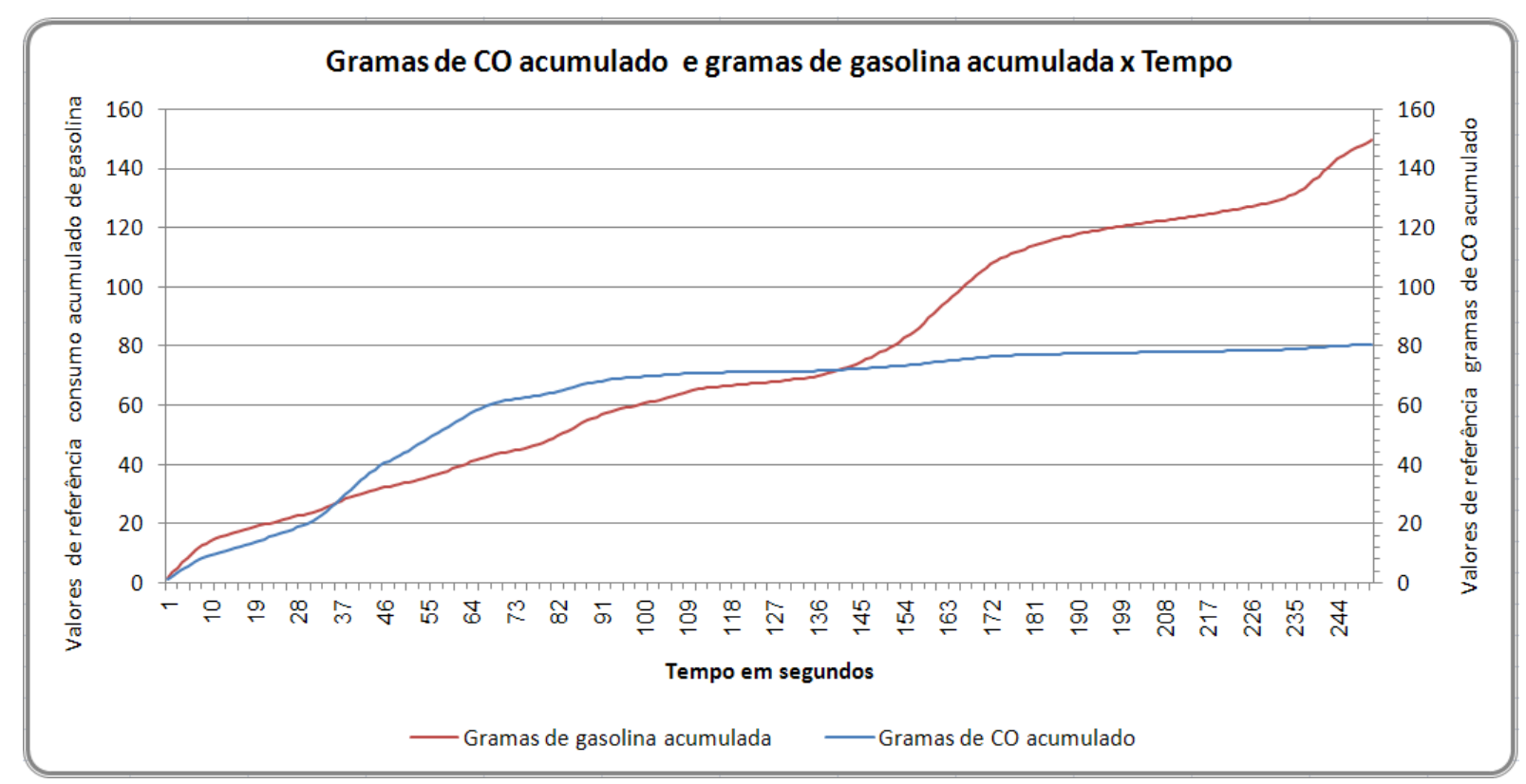

Gráfico 4.2.30 - Gramas CO e Gramas gasolina x tempo

Existe uma relação progressiva entre a quantidade de $\mathrm{CO}$ e a de gasolina em gramas. No decorrer do percurso, essa relação vai se distanciando, o que demonstra a eficiência da queima do combustível, ou seja, o motor vai melhorando a queima conforme a sua temperatura aumenta.

\subsubsection{Análise da emissão de HC com o motor quente no trecho 5}

Os gráficos relacionam a emissão de $\mathrm{HC}$ em gramas com as outras variáveis relevantes medidas durante o ensaio: porcentagem de HC, velocidade, inclinação da via, distância percorrida, temperatura do motor e gramas de gasolina acumulada.

O gráfico 4.2.31 mostra a comparação entre a emissão em gramas de $\mathrm{HC}$ pela porcentagem de $\mathrm{HC}$ emitida. 


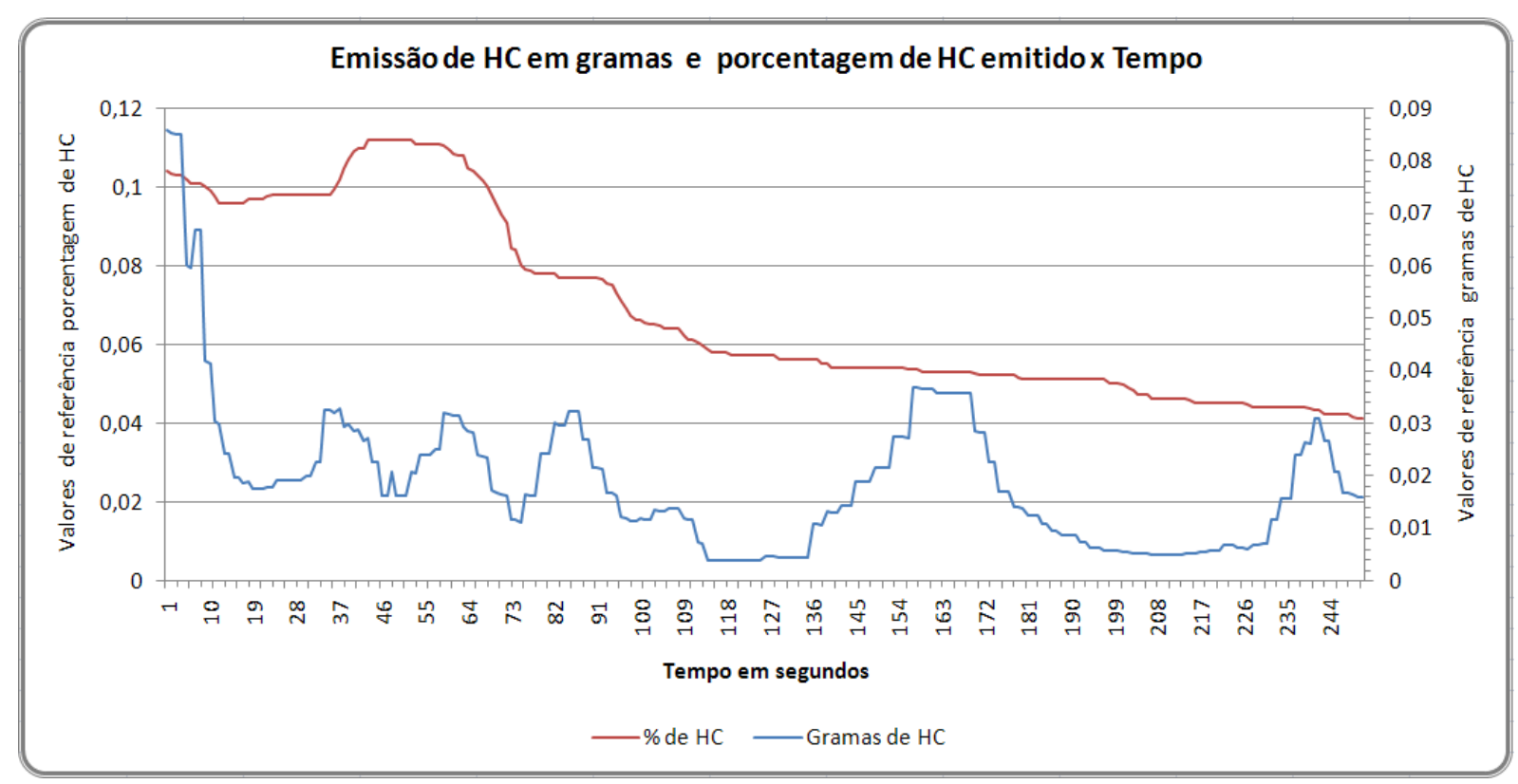

Gráfico 4.2.31 - Gramas HC e \% HC x Tempo

A porcentagem de emissão de $\mathrm{HC}$ e gramas de $\mathrm{HC}$ não é grande, o que se explica, nos dois casos, em razão do aquecimento do motor, como já discutido anteriormente. Lembrando que o analisador de gás tem resolução de 1 ppm, mas tem precisão na ordem de 12 ppm para o HC.

Os pequenos picos, que aparecem se explicam em razão de pequenos aclives e acelerações. Esses mesmos dados, apresentados no gráfico seguinte, não ficam tão visíveis em razão da escala utilizada.

O gráfico 4.2.32 mostra a relação entre a emissão em gramas de $\mathrm{HC}$ pela velocidade. 


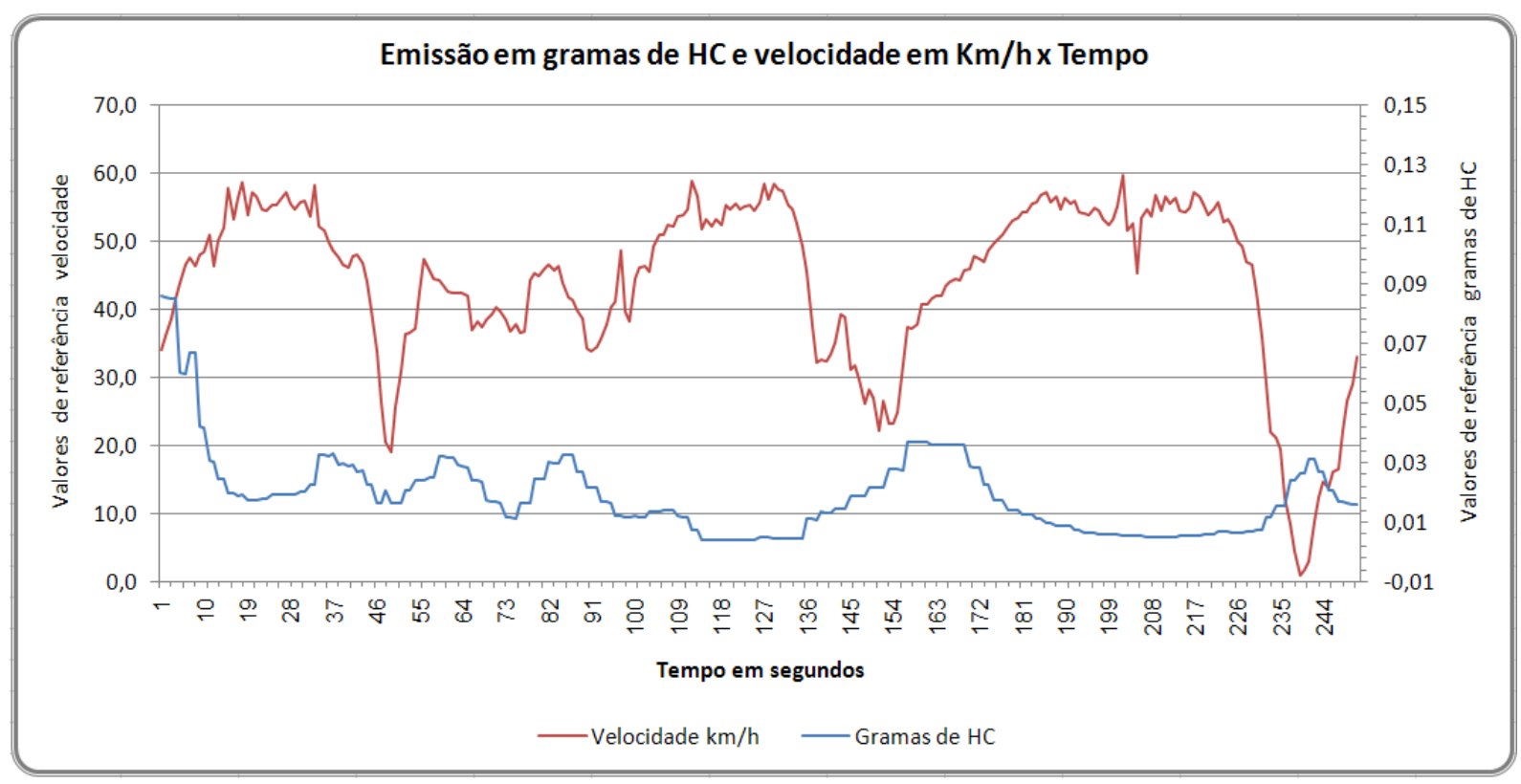

Gráfico 4.2.32 - Gramas HC e Velocidade x Tempo

Nota-se que nem toda variação de velocidade reflete em variação na emissão de $\mathrm{HC}$, já que esta também é influenciada por outros fatores, como acelerações e inclinação da via. Assim, em menor escala, a velocidade não deve ser considerada um fator muito relevante para a emissão de HC.

O gráfico 4.2 .33 mostra a relação entre a emissão em gramas de HC pelo perfil vertical do terreno, ilustrando sua inclinação.

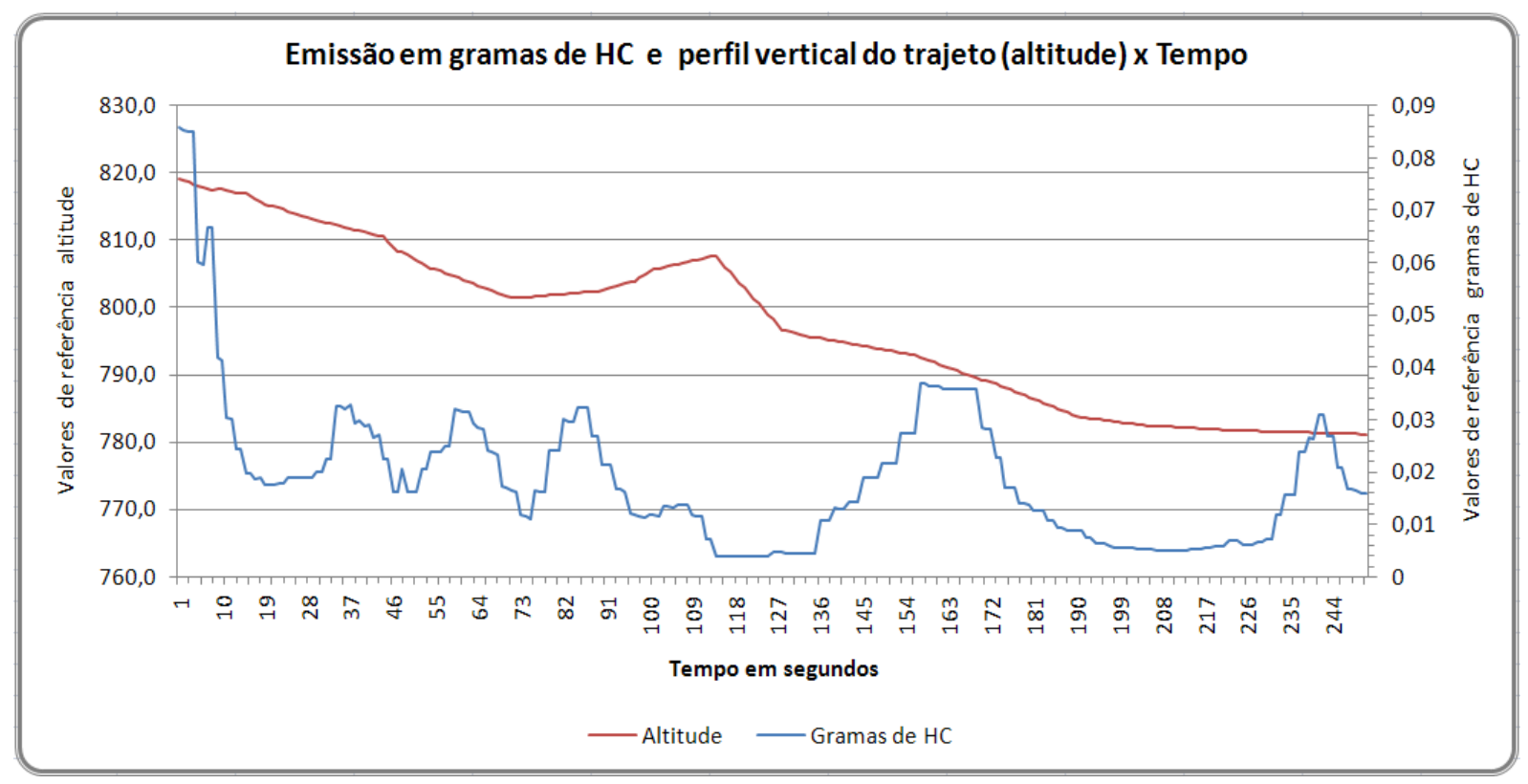

Gráfico 4.2.33 - Gramas HC e Altitude x Tempo 
Ocorre pequena variação na emissão de $\mathrm{HC}$ com relação à altitude da via, tendo em vista que o motor já está aquecido (principal fator de influência) e que o trecho é relativamente plano.

O gráfico 4.2.34 mostra a relação entre a emissão em gramas de $\mathrm{HC}$ pelo aquecimento do motor.

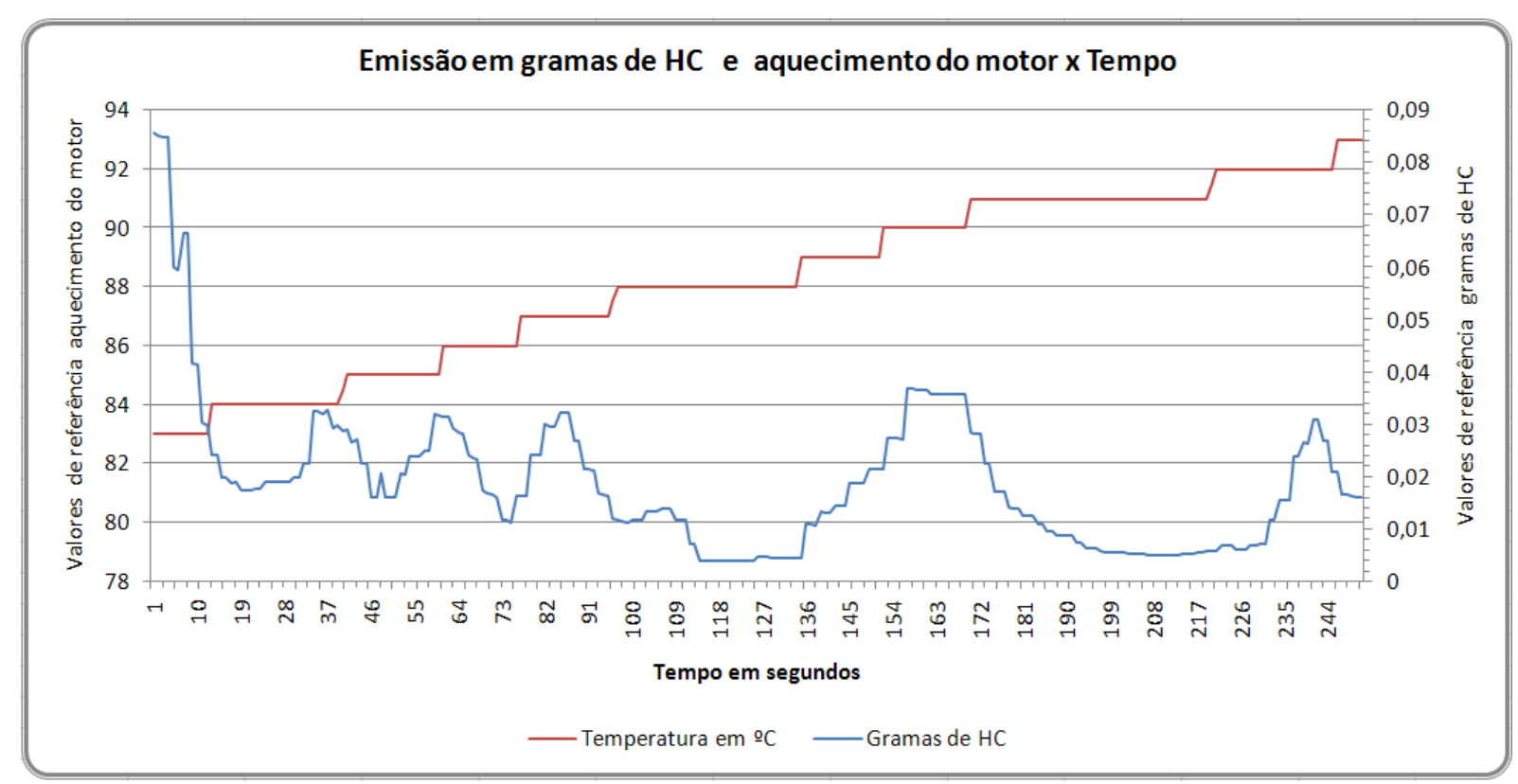

Gráfico 4.2.34 - Gramas HC e Aquecimento do motor x Tempo

O motor não estava tão aquecido neste ensaio, conforme já discutido, portanto, a temperatura subiu durante todo o período do ensaio. Entretanto, para que a temperatura influenciasse diretamente na emissão de $\mathrm{HC}, \mathrm{o}$ motor já estava suficientemente aquecido. Verifica-se, portanto, que, a partir de determinado aquecimento do motor, o aumento progressivo na temperatura não se mostra tão relevante para alterar a emissão de HC.

O gráfico 4.2.35 mostra a relação entre a emissão em gramas de $\mathrm{HC}$ pelo consumo em gramas de gasolina. 


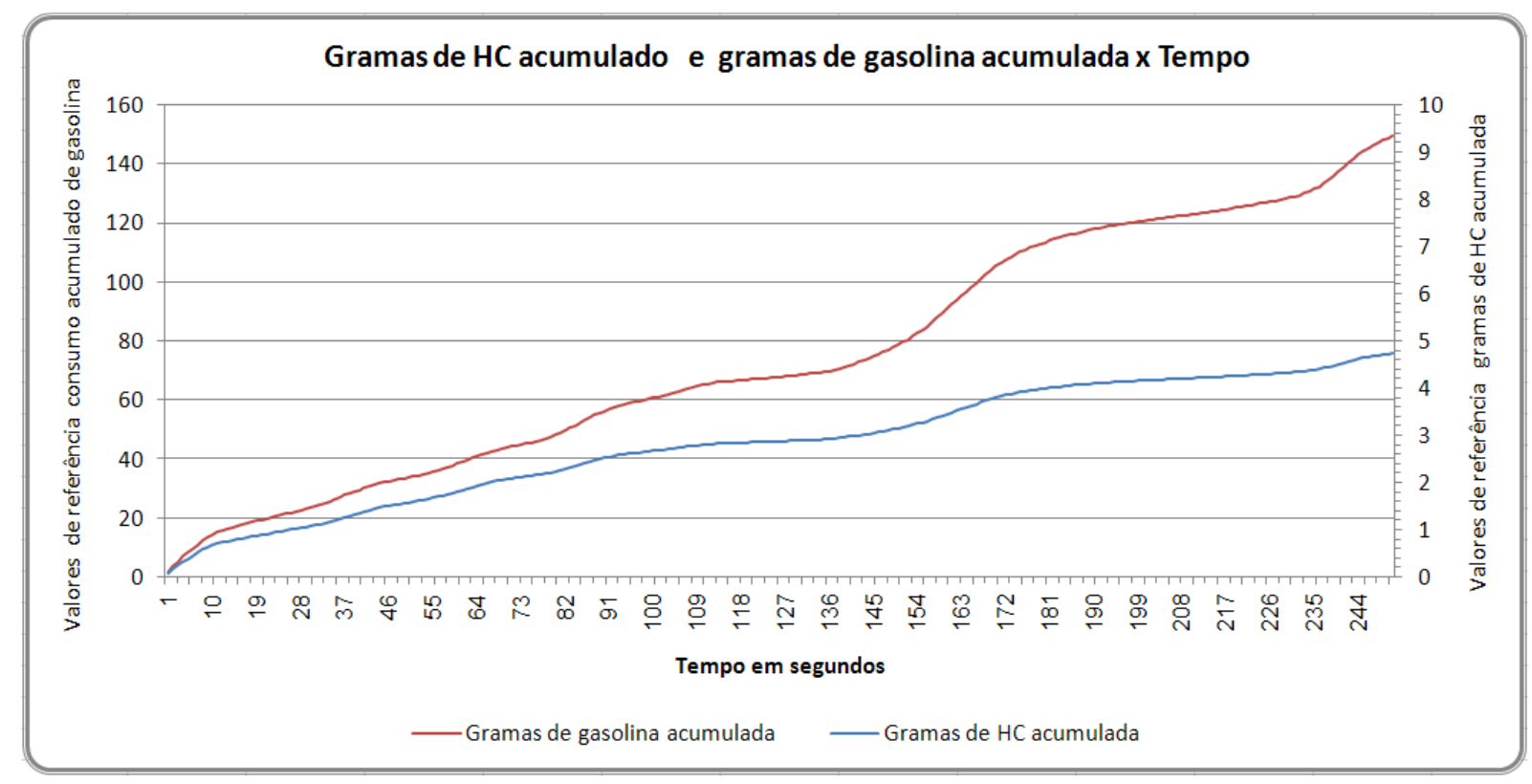

Gráfico 4.2.35 - Gramas HC e Gramas gasolina x Tempo

Existe uma relação progressiva entre a quantidade de $\mathrm{HC}$ emitida e a de gasolina consumida em gramas. No decorrer do percurso, essa relação vai se distanciando, o que demonstra a eficiência da queima do combustível, ou seja, o motor vai melhorando a queima conforme a sua temperatura aumenta.

\subsection{Discussão dos resultados}

A partir de todos os dados levantados durante os ensaios e também com base nas análises ora apresentadas, é possível aperfeiçoar os modelos existentes para a medição da emissão de $\mathrm{CO}$ e $\mathrm{HC}$ dos motores dos veículos. Ocorre que, em geral, os modelos existentes (conforme a discussão no item 2.8, dentro do capítulo 2) se baseiam exclusivamente na velocidade para medir a quantidade de $\mathrm{CO}$ e de $\mathrm{HC}$ emitidos. No decorrer da análise, os dados demonstraram que a velocidade não é o item mais crítico para a avaliação dos gases emitidos para os ensaios realizados.

Verificou-se, especialmente que, a inclinação da via e a temperatura do motor têm influência direta na emissão de $\mathrm{CO}$, com a variável de velocidade em segundo plano. Quanto à emissão de $\mathrm{HC}$, o principal item de influência se refere à temperatura, mas principalmente no início do ensaio. $O$ 
aquecimento, mesmo que pequeno, do motor já é suficiente para diminuir significativamente a emissão de HC. Esta se mostra mais crítica, portanto, nos momentos iniciais, quando o veículo é ligado e colocado em movimento.

A partir da análise dos dados globais obtidos nos ensaios, é possivel concluir que o motor, para o percurso padrão, está suficientemente aquecido e, portanto, com emissão de poluentes mais linear, equilibrada, por volta de 600 segundos ou após percorridos cerca de $6-7 \mathrm{~km}$ - eis o que se pode chamar de motor aquecido.

Para se elaborar inventários e se estimar a real emissão de poluentes, é necessário usar no modelo parâmetros mais realistas que os atualmente utilizados, por exemplo, pela Cetesb, para divulgar os relatórios de qualidade do ar no Brasil. Os parâmetros atuais do inventário de emissões da Cetesb se baseiam em fatores de emissão adaptados da EPA, conforme discutido no item 2.6.5.

O problema é que esses parâmetros, primeiro, não foram feitos para as condições do Brasil; em segundo lugar, esses valores são muito menores que a real emissão de poluentes, conforme se obteve nos ensaios desenvolvidos neste trabalho. Essa grande defasagem mostra há necessidade de se adequarem esses dados à realidade das pequenas e médias cidades brasileiras e que as metodologias adotadas pelos modelos tradicionais merecem revisão.

Se, a partir do banco de dados levantado, forem selecionados apenas aqueles dados que geram situações ideais de trânsito (veículos com o motor aquecido, em vias planas e com velocidade média alta), o veículo estudado emitiria $5,6 \mathrm{~g} / \mathrm{km}$ de $\mathrm{CO}$ e $0,6 \mathrm{~g} / \mathrm{km}$ de $\mathrm{HC}$, valores, ainda assim, muito mais altos que aqueles usados pela Cetesb para fundamentar o inventário (cf. tabela 2.6.5.2).

Se se adotarem os dados exatamente conforme foram coletados, ou seja, de forma mais próxima do real, já que aquelas condições são muito pouco verdadeiras no trânsito diário, principalmente em cidades pequenas e médias, onde os trajetos são, na sua maioria, curtos, e, portanto, os veículos transitam com o motor frio; então, os valores ficam ainda mais destoantes.

A tabela 4.3.1 apresenta como ficaria a média ponderada de todos os trechos analisados, partindo do motor frio no trecho 1 até o fim do trecho 5 , lembrando que no início do percurso o veículo estava a uma altitude de 849,6 m e 
no fim do percurso, estava em uma altitude de $781 \mathrm{~m}$, o que deve favorecer a redução da média de emissão dos gases estudados.

Tabela 4.3.1 - Média ponderada de todos os trechos analisados

\begin{tabular}{|c|c|c|c|}
\hline Trecho & $\begin{array}{c}\text { Distância } \\
(\mathrm{km})\end{array}$ & Emissão de CO $(\mathrm{g} / \mathrm{km})$ & Emissão de HC $(\mathrm{g} / \mathrm{km})$ \\
\hline 1 & 0,73 & 60,3 & 13,3 \\
\hline 2 & 1,23 & 49,6 & 6,4 \\
\hline 3 & 0,99 & 52,2 & 2,0 \\
\hline 4 & 0,7 & 4,8 & 0,3 \\
\hline 5 & 3,1 & 26,9 & 1,5 \\
\hline Trecho Global & 6,75 & 36,0 & 3,6 \\
\hline
\end{tabular}

De acordo com a tabela dos fatores médios de emissão de veículos leves novos da Cetesb (cf. tabela 2.6.5.2), a emissão de CO de um veículo flex a gasolina C de 2004 deveria ser aproximadamente 0,39 g/km e de HC deveria ser aproximadamente $0,08 \mathrm{~g} / \mathrm{km}$, valores muito distintos daqueles acima obtidos (36,0 g/km de CO e 3,6 g/km de $\mathrm{HC})$.

Assim, se o modelo usado para gerar esses inventários não leva em consideração os parâmetros mais reais, a realidade da emissão de poluentes não é espelhada neles. É possível perceber, pelos valores da tabela 4.3.1, o quanto pode ser diferente a emissão de $\mathrm{CO}$ e de $\mathrm{HC}$ em função da diferença no traçado do trecho estudado. 


\section{CONCLUSÕES}

Tendo em vista toda a discussão teórica levantada, foi possível verificar que os modelos hoje existentes para a mensuração da emissão de $\mathrm{CO}$ e de $\mathrm{HC}$ em trajetos curtos em cidades pequenas e médias são insuficientes. Assim, este trabalho teve como principal objetivo 1) levantar a quantidade de emissão desses poluentes da forma mais próxima do real possível, com base em vários parâmetros (emissão de $\mathrm{CO}$, velocidade, inclinação da via, distância percorrida, temperatura do motor e consumo de combustível); e, 2) a partir dos dados obtidos, propor um aperfeiçoamento nos modelos matemáticos existentes para se calcular a emissão de $\mathrm{CO}$ e de $\mathrm{HC}$.

A metodologia utilizada nos ensaios de campo para se determinar a emissão de $\mathrm{CO}$ e $\mathrm{HC}$ nas condições descritas, em 40 amostragens nos primeiros testes e depois em mais 10 amostragens, mostrou-se viável. Os equipamentos portáteis, de fácil montagem e desmontagem e de funcionamento simplificado, facilitaram o trabalho de coleta dos dados.

Os dados obtidos por trecho são expressivos e confiáveis e têm potencial para serem utilizados em outros trabalhos, tanto no âmbito da compreensão do fenômeno da poluição veicular na área urbana, como no entendimento do comportamento do motor à combustão nas condições estudadas, além de gerar dados úteis para se estudar o trânsito na região ensaiada.

Pode-se afirmar que os dados obtidos são precisos (há repetitividade em ensaios com características semelhantes), mas, por outro lado, não é possível afirmar que há muita exatidão nos dados obtidos, o que ocorre em virtude de os fabricantes de alguns equipamentos utilizados no trabalho não fornecerem a exatidão nominal. Isso ocorre no analisador de gases e no computador de bordo que fornece o valor do consumo instantâneo do veículo. No processamento GPS, a precisão pode ser mensurada, portanto, é possível conhecer a grandeza da incerteza de dados como velocidade, aceleração e inclinação da via.

É importante ressaltar que, nos dados coletados, quando a velocidade do veículo é zero, não foi possível mensurar a quantidade de emissão de $\mathrm{CO} / \mathrm{HC}$ naquele período, o que não implica em emissão de $\mathrm{CO}$ zero. Embora tenha sido possível mensurar a porcentagem de $\mathrm{CO} / \mathrm{HC}$ emitida, não foi possível mensurar 
a emissão dos poluentes em gramas, o que não significa que eles não tenham sido emitidos. De qualquer forma, no modelo, esses valores acabaram sendo registrados como zero, ou seja, os resultados reais são mais pessimistas que os dados efetivamente processados. Uma forma possível de se executar essa tarefa seria encher o tanque do veículo e deixá-lo ligado, mas sem movimento, por um período. Depois, o tanque seria reabastecido e, a partir da verificação da quantidade de combustível gasta naquele período de tempo, de acordo com a variação da temperatura, seria possível calcular-se essa emissão. Esta é uma tarefa que pode ser executada no futuro para se aperfeiçoar ainda mais os resultados obtidos.

Outra informação relevante é que o consumo de combustível, medido por meio do computador de bordo do veículo, está balizada no mínimo em $4 \mathrm{~km} / \mathrm{l}$ e no máximo em $50 \mathrm{~km} / \mathrm{l}$.

De qualquer forma, os dados são válidos, pois as imprecisões encontradas nas medições não geram grau de erro que chegue a desqualificar a sua grandeza. De fato, está demonstrado que a emissão real de $\mathrm{CO}$ e de HC é muito maior para percursos curtos em cidades pequenas e médias que os valores gerados pelos modelos de estimativa, conforme levantados na literatura.

A emissão de $\mathrm{HC}$ no decorrer dos testes com o motor frio sempre foi ficando menor e se aproximando daquela obtida no modelo adotado pela ANTP, independentemente da inclinação do terreno. Por outro lado, também foi possível verificar que a emissão de HC é menor quando o motor está aquecido e em declive. Assim, quanto à emissão de $\mathrm{HC}$, a variável mais relevante é a temperatura do motor e, em segundo plano, a inclinação da via e de maneira menos relevante ainda, a velocidade.

Quando o motor está frio, ou seja, nos primeiros momentos do percurso, a variável mais significativa é a temperatura no que se refere à emissão de CO em gramas. Conforme o motor se aquece, outras variáveis, como a inclinação da via (maior esforço do motor), passam a ter maior influência na emissão. No que tange à emissão de $\mathrm{CO}$, o resultado obtido vai-se reduzindo conforme aumenta a temperatura do motor. Entretanto, a inclinação da via também vai influenciar nesse valor, aumentando a emissão em situação de aclive, mesmo com o motor aquecido. Assim, é possível afirmar que a situação mais desfavorável para a emissão de CO associa motor frio e aclive; a situação mais favorável associa motor quente com declive da via. Portanto, um modelo que pretenda aproximar-se da real emissão dos 
gases poluentes não deve levar em consideração apenas um parâmetro, por mais relevante que este seja, tendo em vista que a emissão de $\mathrm{CO}$ depende da conjunção de fatores como temperatura e inclinação da via e não só de um deles.

Outra questão que se mostrou relevante refere-se à temperatura climática: foi possível verificar que em períodos mais quentes (em geral, à tarde) o motor se aquece mais rapidamente que em momentos mais frios (em geral, pela manhã). Portanto, o modelo pode gerar resultados diferentes em cidades com climas mais quentes ou mais frios, apesar de os resultados não variarem tanto na ordem de grandeza.

A pesquisa se mostrou satisfatória para o que se propôs, entretanto, ainda há vários aspectos relevantes que poderiam ser abordados em pesquisas futuras, a partir dos mesmos dados aqui levantados e da mesma metodologia aqui empregada. Assim, outros trabalhos poderiam se referir a outros poluentes; à relação da emissão dos mesmos poluentes em carros com potência de motor distinta.

A partir de outras áreas do conhecimento, poderiam ser feitas amostragens de ar nos locais onde individualmente os veículos se mostram mais poluidores (aclives e difícil dispersão de poluição) e criar correlação, de modo orientar que se evitem aglomerações próximas (pontos de ônibus, comércio) ou gerar formas de dispersar melhor os gases poluidores que ali se acumulam.

Com base neste trabalho também é possível propor políticas públicas para incentivar o uso de veículos alternativos para trajetos curtos, como as bicicletas ou mesmo incentivar que as pessoas andem mais. Obviamente esse tipo de estímulo passaria por investimento público em ciclovias e calçadões, no incentivo a empresas fabricantes de bicicletas, com eventual redução de impostos. Outra proposta poderia ser tributar mais os veículos que emitem mais gases poluidores, cuja renda poderia ser revertida justamente no desenvolvimento das ciclovias e calçadões e também na melhoria da dispersão dos poluentes nas cidades.

Outra proposta desafiadora constituiria em articular $\mathrm{O}$ planejamento do uso e da ocupação do solo com a melhoria do sistema viário, no intuito de, por um lado, reduzir as emissões e, por outro, facilitar a dispersão dos poluentes. 
Os resultados deste trabalho servem para conscientizar os administradores públicos acerca da necessidade de se mensurar a real emissão de poluentes em qualquer cidade, pois o número reduzido de automóveis não significa diretamente a inexistência de problemas com a poluição. Especialmente no caso das cidades pequenas e médias, esse resultado, mais fácil de se obter (percursos menores), auxiliaria a uma política preventiva, para que não se alcancem os níveis catastróficos que hoje são encontrados nas grandes cidades.

A partir da mensuração real das emissões em cada cidade, cabe aos administradores organizar o trânsito não apenas com o objetivo de fluência, mas também para evitar a concentração de veículos e, portanto, a concentração de poluentes em determinada região. Tal organização, atualmente, é elaborada com base em inventários padronizados, que não levam em conta nem a especificidade geográfica e topográfica de cada cidade nem as emissões dos modelos de veículos que mais circulam por determinada região. É fato que os trajetos mais comuns em cidades pequenas e médias são curtos e, portanto, os veículos circulam boa parte do tempo com o motor frio, situação bastante desfavorável para a emissão de gases. A mensuração real, conforme proposta neste trabalho, evidencia que a situação de emissão de gases nessas circunstâncias pode-se mostrar muito pior que aquela obtida pela simples aplicação padronizada de um modelo. Assim, apenas a mensuração de cada caso específico poderia fornecer informações verdadeiras a respeito do problema. 


\section{REFERÊNCIAS BIBLIOGRÁFICAS}

AGÊNCIA NACIONAL DO PETRÓLEO, GÁS NATURAL E BIOCOMBUSTÍVEIS (2003). Anuário estatístico brasileiro do petróleo e do gás natural - 2003. Rio de Janeiro. Disponível em:<http://www.anp.gov.br/petro/dados_estatisticos.asp>. Acesso em 10 jun 2006.

ALVIM, C.F. et al. (2000). Energia final e equivalente - procedimento simplificado de conversão. Economia \& Energia, São Paulo, ano 9, n.18, jan/fev Disponível em:<http://ecen.com/eee18/enerequi.htm\#energiaeq>. Acesso em 21 jul 2005.

(2008). Avaliação das emissões evitadas pela política energética brasileira no setor transporte rodoviário. Economia \& Energia, ano 12, n.70, out/nov. Disponível em: <http://ecen.com/eee70/eee70p/emissoes_transporte.htm>. Acesso em 16 ago 2005.

AMERICAN SOCIETY HEATING AND REFRIGERATION ENGINEERS (2007). Disponível em: <http://www.ashrea.org>. Acesso em 15 maio 2007.

ARBEX, M.A. et al. (2004). Queima de biomassa e efeitos sobre a saúde. Jornal Brasileiro de Pneumologia. São Paulo, v.30, n.2, mar/abr. Disponível em: $<$ http://www.scielo.br/scielo.php?script=sci_arttext\&pid=S1806$37132004000200015>$. Acesso em 10 jun 2007.

AZUAGA, D. (2000). Danos ambientais causados por veículos leves no Brasil. 168p. Dissertação (Mestrado) - Universidade Federal do Rio de Janeiro, Rio de Janeiro, 2000.

BAIRD, C. (2002). Química ambiental. 2.ed. Porto Alegre: Bookman.

BALANÇO energético e de emissões. (2002). Economia \& Energia. São Paulo, ano 6, n.31, mar/abr Disponível em:<http://ecen.com/eee31/benemis1.htm>. Acesso em 15 set 2006.

BOHM, G.M. (2001). Health effects of urban air pollution: biological indicators studies and epidemiological analysis in Sao Paulo, Brazil. In: INTERNACIONAL CONFERENCE ON ENVIRONMENTAL MUTAGENS, 8., Shizuaka, 2001. Mutation research Amsterdam... Amsterdan: [s.n.]. v.483, supl.1, p.S12, res.IE-3.

BRASIL - Energia em 2001: principais indicadores. (2002). Economia \& Energia, São Paulo, ano 6, n.33, jul/ago. Disponível em: <http://ecen.com/eee33/brasilenerg2001.htm>. Acesso em 15 set 2006.

BRASIL - energia em 2002: principais indicadores. (2003). Economia \& Energia, São Paulo, ano 7, n.39, jul/ago. Disponível em:

<http://ecen.com/eee39/brasil_energia_em_2002.htm>. Acesso em 15 set 2006. 
BRAUN, S.; APPEL, L.G.; SCHMAL, M. (2004). A poluição gerada por máquinas de combustão interna movidas a diesel - a questão dos particulados. Estratégias atuais para a redução e controle das emissões e tendências futuras. Química Nova. São Paulo, v.27, n.3, p.472-482.

CAMADA limite atmosférica (2008). In: WIKIPÉDIA: a enciclopédia livre. Disponível em: <http://pt.wikipedia.org/wiki/Camada_limite_planet\%C3\%A1ria>. Acesso em 10 set 2007 .

CASTRO, H.A.; GOUVEIA, N.; ESCAMILLA-CEJUDO, J.A. (2003). Questões metodológicas para a investigação dos efeitos da poluição do ar na saúde. Revista Brasileira de Epidemiologia. São Paulo, v.6, n.2, p.135-148.

CAVALCANTI, P.M.S. (2003). Avaliação dos impactos causados na qualidade do ar pela geração termelétrica. Dissertação (Mestrado) - Universidade Federal do Rio de Janeiro, Rio de Janeiro.

CENTRO DE INFORMAÇÕES DE DADOS DO RIO DE JANEIRO (2001). Anuário estatístico do estado do Rio de Janeiro. Rio de Janeiro: Secretaria de Estado de Planejamento e Controle.

COMPANHIA DE TECNOLOGIA DE SANEAMENTO AMBIENTAL (2008). Poluente. São Paulo. Disponível em: <http://www.Cetesb.sp.gov.br/Ar/ar_saúde.asp>. Acesso em 15 nov 2008.

CONSELHO NACIONAL DO MEIO AMBIENTE (1989). Resolução Conama $n^{\circ}$ 05, de 15 de junho de 1989. Dispõe sobre o Programa Nacional da Poluição do Ar PRONAR. Brasília: CONAMA.

CONSELHO NACIONAL DO MEIO AMBIENTE (1990a). Resolução Conama $n^{\circ} 03$, de 28 de junho de 1990. Dispõe sobre padrões de qualidade do ar, previstos no PRONAR. Brasília: CONAMA.

CONSELHO NACIONAL DO MEIO AMBIENTE (1990b). Resolução Conama $n^{\circ} 08$, de 28 de junho de 1990. Dispõe sobre padrões de emissão para instalação de novas fontes de combustão externa do ar, previstos no PRONAR. Brasília: CONAMA.

CONSELHO NACIONAL DO MEIO AMBIENTE (1997). Resolução Conama $n^{\circ} 237$, de 22 dezembro 1997. Regulamenta os aspectos de licenciamento ambiental estabelecido na Política Nacional de Meio Ambiente. Brasília: CONAMA.

CYBIS, H.B.B.; LINDAU, L.A.; ARAUJO, D.R.C. (2002). Implantação de um modelo de simulação e alocação do tráfego em Porto Alegre. Revista dos Transportes Públicos. Rio de Janeiro, ano 24, p.41-54, 2.Trim.

DELUCCHI, M.A. (2004). The Annualized social cost of motor-vehicle use in the United States, based on 1990-1991 Data. Daves: University of California, Institute of Transportation Studies.

DE SOUZA, A.M. (2004). Estudo de emissões de vapores orgânicos no carregamento de gasolina em caminhões-tanque. Dissertação (Mestrado) Universidade Federal da Bahia, Salvador. 
DEPARTAMENTO DE TRÂNSITO DO ESTADO DO RIO DE JANEIRO; FUNDAÇÃO ESTADUAL DE ENGENHARIA E MEIO AMBIENTE DETRAN (2001). Poluição veicular no estado do Rio de Janeiro. Rio de Janeiro: Detran; Feema.

DEPARTAMENTO NACIONAL DE TRÂNSITO (2007). Disponível em: <http://www.denatran.gov.br/>. Acesso em 18 abr 2008.

DUBEUX, C.B.S. [2006?]. Avaliação do Programa de Inspeção e Manutenção de veículos em uso do Rio de Janeiro. Rio de Janeiro: LIMA/MMA. Disponível em:<http://www.cleanairnet.org/saopaulo/1759/articles-71047_resource_5.pdf>. Acesso em 20 out 2006.

EMPRESA BRASILEIRA DE PLANEJAMENTO DE TRANSPORTE (2001). Anuário estatístico de transportes 2001. Brasília. Disponível em:<http://www.geipot.gov.br>. Acesso em 10 set 2005.

ENVIRONMENTAL PROTECTION AGENCY (1997). Handbook for criteria pollutant inventory development: a beginner's guide for point and area sources. Washington, DC: EPA. Disponível em: <http://www.epa.gov/oar/aqtrnd2003/>. Acesso em 24 maio 2005.

. (2003). National air quality and emission trends report. Washington, DC: EPA. Disponível em:<http://www.epa.gov/oar/aqtrnd2003/>. Acesso em 13 maio 2004.

. (2004). Mobile source emissions - past, present and future, 2004.

Washington, DC: EPA. Disponível em:

<http://www.epa.gov/otaq/invntory/overview/examples.htm>. Acesso em 8 set 2005.

ESPECTOMETRIA de infravermelho. (2006). [S.I.]: Lindle Gases. Disponível em: $<$ http://hiq.aga.com.br/International/Web/LG/Br/likelgspgbr.nsf/DocByAlias/anal_infra \#2>. Acesso em 25 out 2007.

EUROPEAN COMMISION (2006). Disponível em:

<http://ec.europa.eu/environment/air/index_en.htm >. Acesso em 15 mai 2006.

EUROPEAN ENVIRONMENT AGENCY (2002). Atmospheric emission inventory guidebook - 2002. Copenhagen: EEA. Disponível em:

<http://www.reports.eea.eu.int/>. Acesso em 20 jan 2007.

. (2003). Atmospheric emission inventory guidebook - 2003. Copenhagen:

EEA. Disponível em: <http://www.reports.eea.eu.int/>. Acesso em 20 jan 2007.

. (2004). Annual european community CLRTAP emission inventory $1990-$ 2002. Copenhagen: EEA. Disponível em:<http://www.reports.eea.eu.int/>. Acesso em 20 jan 2007.

FAIZ, A.; WEAVERT, C.S.; WALSH, M.P. (1998). Controlling emissions from in-use vehicles: the role of inspection and maintenance (I/M) programmes. International Journal of Vehicle Design. Olney, v.20, n.1-4, p.304-312. 
(1996). Air pollution from motor vehicles: standards and technologies for controlling emissions. Washington, DC.: The World Bank.

FARAH, M.A. (2004). Caracterização do petróleo e seus produtos. Apostila do Curso de Formação de Engenheiros de Processamento da Petrobras. Rio de Janeiro: Universidade Corporativa da Petrobrás.

FUNDAÇÃO ESTADUAL DE ENGENHARIA DO MEIO AMBIENTE (2004). Inventário de fontes emissoras de poluentes atmosféricos da região metropolitana do Rio de Janeiro. Rio de Janeiro: Feema. Disponível em: <http://www.feema.rj.gov.br>. Acesso em 15 set 2005.

FUNDAÇÃO SISTEMA ESTADUAL DE ANÁLISE DE DADOS (2008). São Paulo: Seade. Disponível em: <http://www.seade.gov.br>. Acesso em 20 jun. 2008.

FERREIRA, O.C. (1998). Projeção da demanda de combustíveis para o ciclo Otto no Brasil. Economia \& Energia. São Paulo, ano 2, n.6, jan/fev. Disponível em: <http://ecen.com/eee_assunto/dem_comb.htm>. Acesso em 21 jul 2005.

(2001). Efeito estufa e consumo de combustíveis. Economia \& Energia, São Paulo, ano 5, n.26, maio/jun. Disponível em: <http://ecen.com/eee26/emis_omar.htm>. Acesso em 11 jun 2006.

FREITAS, M.K. (2003). Investigação da produção e dispersão de poluentes do ar no ambiente urbano: determinação empírica e modelagem em rede neural da concentração de CO. Tese (Doutorado) - Escola de Engenharia de São Carlos, Universidade de São Paulo, São Carlos, 2003.

FROTA de veículos diesel no transporte rodoviário. (1999). Economia \& Energia. São Paulo, ano 3, n.16, set/out. Disponível em: <http://ecen.com/eee16/frotabr.htm>. Acesso em 21 jul 2005.

FROTA e consumo de veículos leves no Brasil. (2000). Economia \& Energia. São Paulo, ano 4, n.21, maio/jun. 2000. Disponível em:

<http://ecen.com/eee_assunto/frota_veic.htm>. Acesso em 21 jul 2005.

GELLER, H. et al. (2004). Policies for advancing energy efficiency and renewable energy use in Brazil. Energy Policy. Amsterdam, v.32, n.12, p.1437-1450, ago.

GERALDI, C.R.S. et al. (2008). Comparativo das emissões de CO2 em um veículo flex utilizando gasolina e suas misturas com álcool etílico anidro e hidratado combustível. In: Simpósio internacional de engenharia automotiva: o aquecimento global e a mobilidade no século XXI, tecnologias para obtenção do desenvolvimento sustentável, 16. São Paulo, 2008. Anais... Disponível em:

<http://aea.org.br/twiki/pub/AEA/PAPERS/PAP0006-18.09-11h00-Sala2.pdf>. Acesso em 20 out 2007.

GOUVEIA, N.; CIFUENTES, L. (2003). Análise dos benefícios na saúde do controle de emissões globais. In: Seminário de gestão da qualidade do ar da iniciativa ar limpo nas cidades da América Latina. Rio de Janeiro: Anais... Disponível em: $<$ http://www.ppe.ufrj.br/ppe/production/tesis/Inloureiro.pdf>. Acesso em 25 mar. 2006. 
GOUVEIA, N. et al. (2002). Poluição do ar e saúde em duas grandes metrópoles brasileiras na década de 90. Informe Epidemiológico do SUS. Brasília, v.11, n.1, p.41-43.

GURGEL VERAS, C.A.; MELO, C.R.V. (2004). Sistema integrado para medição de poluentes, em tempo real, em veículos do ciclo Otto. Brasília: UnB.

HARRINGTON, W.; McCONNELL, V.; ANDO, A. (2000). Are vehicle emission inspection programs living up to expectations? Transportation Research Part $D$ : transport and environment, Amsterdam, v.5, n.3, p.153-172, mai. Disponível em: <http://www.ingentaconnect.com/content/els/13619209/2000/00000005/00000003/art 00029;jsessionid=orpivw9945kr.alice?format=print>. Acesso em 30 jul 2005.

HARRISON, R.M. (1991). Pollution: causes, effects and control. 2.ed. Cambridge: The Royal Society of Chemistry.

HESKETH, H.E. (1972). Understanding \& controlling air pollution. Ann Arbor: Science.

INSTITUTO BRASILEIRO DE GEOGRAFIA E ESTATÍSTICA (2008). Brasília. Disponível em: <http://.ibge.gov.br>. Acesso em 10 nov 2008.

INSTITUTO DE PESQUISA ECONÔMICA APLICADA; AGÊNCIA NACIONAL DE TRANSPORTE PÚBLICO (1997). Redução das deseconomias urbanas pela melhoria do transporte público. Rio de Janeiro: IPEA; ANTP.

KATZ, M. (1977). Methods of air sampling and analysis. 2.ed. Washington, DC: APHA.

JACONDINO, G. (2005). Quantificação das emissões veiculares através do uso de simuladores de tráfego. Tese (Doutorado) - Escola de Engenharia, Universidade Federal do Rio Grande do Sul, Porto Alegre, 2005.

JACONDINO, G.B.; CYBIS, H.B.B. (2003). Análise do efeito da agregação das variáveis do tráfego na estimativa de emissões veiculares. In: Semana de engenharia de produção e transportes, 3. Porto Alegre, 2000. Anais... Porto Alegre: UFRGS. Disponível em:

$<$ http://redpgv.coppe.ufrj.br/arquivos/jacondino_cybis_3\%C2\%AA\%20Semana\%20de \%20Engenharia\%202003.pdf>. Acesso em 25 mar $2 \overline{00}$.

LANDMANN, M.C. (2004). Estimativa das emissões de poluentes dos automóveis na RMSP considerando as rotas de tráfego. In: Encontro da associação nacional de pós-graduação e pesquisa em ambiente e sociedade, 2. São Paulo, 2004. Anais... Disponível em: <http://anppas.org.br/encontro/segundo/Papers/papers.html>. Acesso em 5 fev 2007.

LOMBORG, B. (2008). Muita calma nessa hora: o guia de um ambientalista cético sobre o aquecimento global. Rio de Janeiro: Campus/Elsevier.

LOUREIRO, L.N. (2005). Panorâmica sobre emissões atmosféricas. Estudo de caso: avaliação do inventário emissões atmosféricas da região metropolitana do Rio de 
Janeiro para fontes móveis. 153p. Dissertação (Mestrado) - Universidade Federal do Rio de Janeiro, Rio de Janeiro, 2005.

MACLEAN, H.L.; LAVE, L.B. (2003). Evaluating automobile fuel/propulsion system technologies. Progress in Energy and Combustion Science. Oxford, v.29, n.1, p.1-69.

MAFRA, O.; EIDELMAN, F. (2008). Emissões de $\mathrm{CO}_{2}$ provenientes da queima de combustível. Comparação entre os valores da IEA e da e\&e/MCT. Economia \& Energia. São Paulo, ano 12, n.66, fev/mar. Disponível em:

<http://ecen.com/eee66/eee66p/emissoes_de_co2_provenientes_da_queima_de_co mbustivel.htm>. Acesso em 15 set 2008.

MENDES, F.E. (2004). Avaliação de programas de controle de poluição atmosférica por veículos leves no Brasil. 179p. Tese (Doutorado) - Universidade Federal do Rio de Janeiro, Rio de Janeiro, 2004.

MENDONÇA, F.A. (1994). Clima e o planejamento urbano de cidades de porte médio e pequeno: proposição metodológica para estudo e sua aplicação a cidade de Londrina/PR. 338p. Tese (Doutorado) - Faculdade de Filosofia, Ciências e Letras, Universidade de São Paulo, São Paulo.

MINISTÉRIO DE MINAS E ENERGIA (2003). Balanço energético nacional 2003. Brasília: MMME. Disponível em: <http://www.mme.gov.br>. Acesso em 26 out 2006.

MOREIRA, D.; TIRABASSI, T. (2004). Modelo matemático de dispersão de poluentes na atmosfera: um instrumento técnico para a gestão ambiental. Ambiente \& Sociedade. Campinas, v.7, n.2, jul/dez. Disponível em:

$<$ http://www.scielo.br/scielo.php?script=sci_arttext\&pid=51414-

753X20040002000010\&eng=en\&nrm=iso\&thg=pt>. Acesso em 30 out 2004.

MÔNICO, J.F.G. (2000). Posicionamento pelo NAVSTAR - GPS: descrição, fundamentos e aplicações. São Paulo: Ed.UNESP.

MURGEL, E.M.; SZWARC, A. (1989). Condições de tráfego e a emissão de poluentes. Revista CETESB de Tecnologia. São Paulo, v.3, n.1, p.3-79.

MURGEL, E.M. et al. (1987). Inventário de emissão veicular - metodologia de cálculo. Revista de Engenharia Sanitária. São Paulo, v.26, n.3, p.50-86, jul/set.

NOLL, K.E.; DAVIES, W.T.; DUNCAN, J.R. (1975). Air pollution control and industrial energy production. Ann Arbor: Science.

NOVAES, A.B. (2005). Inspeção técnica veicular - modelos de estações. 84p. Dissertação (Mestrado) - Universidade Estadual de Campinas, Campinas, 2005.

ONURSAL, B.; GAUTAM, S.P. (1997). Vehicular air pollution: experiences from seven Latin American. Washington, DC: World Bank Technical Paper.

PATUSCO, J.A.M. (1998). Balanço de energia útil - BEU. Economia \& Energia. São Paulo, ano 2, n.10, set/out. Disponível em: <http://ecen.com/eee10/beupp.htm>. Acesso em 15 set 2008. 
PERES, F.F. (2005). Meio ambiente e saúde: os efeitos fisiológicos da poluição do ar no desempenho físico - o caso do monóxido de carbono (CO). Arquivos em movimento. Rio de Janeiro, v.1, n.1, p.55-63, jan/jun.

PIRES, D.O. (2005). Inventário de emissões atmosféricas de fontes estacionárias e sua contribuição para a poluição do ar na região metropolitana do Rio de Janeiro. 188p. Dissertação (Mestrado) - Universidade Federal do Rio de Janeiro, Rio de Janeiro, 2005.

PIZZOTTI, L.E.; XAVIER, J.E.N.; LOUREIRO, V. (2003). Recomendações para o Desenvolvimento de Atividades na Área de Qualidade do Ar na Bacia Aérea III da Região Metropolitana do Rio de Janeiro. In: Seminário internacional: os avanços no estudo de caso da qualidade do ar da bacia aérea, 3. Rio de Janeiro, 2003. Disponível em: < http://www.cleanairnet.org/lac/1471/articles-55982_agenda.pdf >. Acesso em 4 jun 2005.

PROGRAMA NACIONAL DE RACIONALIZAÇÃO DO USO DOS DERIVADOS DO PETRÓLEO E DO GÁS NATURAL (2007). O Que é o programa economizar? Rio de Janeiro: Conpet. Disponível em:

<http://www.conpet.gov.br/projetos/economizar_o!php?segmento=corporativo>. Acesso em 20 jul. 2007.

REAL, M.V. et al. (2002). Barreiras na implantação de alternativas energéticas no setor rodoviário no Brasil. Rio de Janeiro: UFRJ.

RIBEIRO, S.K. et al. (2003). Transporte mais limpo. Rio de Janeiro: Creatio Design e Comunicação.

RIBEIRO, S.K. et al. (2003). Transporte mudanças climáticas. Rio de Janeiro: MAUAD.

SAMPAIO, A.H.L. (1981). Correlações entre uso do solo e ilhas de calor no ambiente urbano: o caso de Salvador. 103p. Dissertação (Mestrado) - Faculdade de Filosofia, Letras e Ciências Humanas, Universidade de São Paulo, São Paulo.

SÃO PAULO (Estado). Ministério Público do Estado de São Paulo. (2006).

Monitoramento da qualidade do ar. São Paulo. (Relatório - Qualidade do ar - Série relatórios (2003) - CETESB). Disponível em:

<http://www.mp.sp.gov.br/pls/portal/docs/page/cao_urbanismo_e_meio_ambiente/bib lioteca_virtual/bv_informativos_tecnicos/monitoramento.pdf>. Acesso em 15 out 2007.

SEGANTINI, P.C.L. (2005). GPS Sistema de posicionamento global. São Carlos: EESC/USP.

SEINFELD, J.H.; PANDIS, S.N. (2006). Atmospheric chemistry and physics: from air pollution to climate change. Canada: John Wiley.

SHER, E. (1998). Handbook of air pollution from internal combustion engines: pollutant formation and control. San Diego: Academic Press. 
SILVA, A.N.R.; FERRAZ, A.C.P. (1994). Densidades urbanas $X$ custos de serviços públicos: análise do caso de São Carlos. In: CONGRESO PANAMERICANO DE INGENIERÍA DE TRÁNSITO Y TRANSPORTES, 8. Memórias... México: Asociación Mexicana de Ingeniería de Transportes. Tomo II, p.1003-1020. Disponível em: $<$ http://www.stt.eesc.usp.br/anelson/STT86408/Modelos.PDF>. Acesso em 30 jul 2007.

SILVA FILHO, A.V. (2006). O Ensaio de emissão veicular: fórum de discussão dos resultados do ensaio de proficiência em emissões veiculares. Rio de Janeiro: Inmetro. Disponível em:< http://www.inmetro.gov.br/ inmetrocientifica/palestra/astorfilho.pdf>. Acesso em 30 jun 2008.

SOUFEN JR., J.; TOLEDO, M. (2007). Ribeirão alcança a marca de 1,96 habitante por veículo. Folha de São Paulo. São Paulo, 14 mar. Folha Ribeirão, p.C1.

SZLO, A.S. et al. (2003). Brazilian energy policies side - effects on $\mathrm{CO}_{2}$ emissions reduction. Energy Policy. v.33, n.3, p.363-394, fev.

TECNOMOTOR ELETRÔNICA DO BRASIL (2002). TM 131 analisador de gases: manual de operações. São Carlos: Tecnomotor. Disponível em: <http://www.tecnomotor.com.br>. Acesso em 10 mai 2006.

TURNS, S.R. (2000). An Introduction to combustion: concepts and applications. 2.ed. Pennsylvania: McGraw- Hill.

URIA, L.A.B.; SCHAEFFER, R. (1997). Efeito radioativo das emissões de gases de efeito estufa por parte de automóveis no Brasil. Revista Brasileira de Energia. Itajubá, v.6, n.1.

WACHS, M.; KOENING, J.G. Behavioral modelling, accessibility and travel need. In: HENSHER, D.A.; STOPHER, P.R. (Ed.). Behavioral travel modeling. London: Croam Helm. p.698-710.

WORLD RESOURCES INSTITUTE (1999). Disponível em: <http://www.wri.org>. Acesso em 14 ago 2008. 
Anexo 


\section{Apêndice}




\section{1 - OBJETIVO}

Determinar valores de teor de álcool etílico anidro combustivel, destilação, aparência (aspecto e cor), número de octano motor - MON, índice antidetonante $I A D$, composição quanto ao tipo de hidrocarboneto, massa específica a $20^{\circ} \mathrm{C}$, teor de benzeno para a amostra de gasolina.

\section{2 - CONSIDERAÇÕES INICIAIS} solicitante.

A amostra de gasolina foi coleta e enviada para análise pelo próprio

\section{3 - METODOLOGIA}

A amostra de gasolina enviada foi avaliada através dos seguintes ensaios e métodos: teor de álcool etílico anidro combustível (ABNT NBR 13992:1997), destilação (ABNT NBR 9619:2005), aparência - aspecto e cor (visual - IT LABCom-357, revisão 002), número de octano motor - MON (infravermelho), índice antidetonante - IAD (infravermelho), composição quanto ao tipo de hidrocarboneto (infravermelho), massa específica a $20^{\circ} \mathrm{C}$ (ABNT NBR 14065:2006) e teor de benzeno (ASTM D6277:2006).

\section{4 - RESULTADOS}

Os resultados obtidos nas análises para a amostra de gasolina é apresentado na Tabela 2 e referem-se somente a amostra enviada pelo próprio solicitante. 
Tabela 2. Resultados obtidos nas análises da amostra de gasolina.

\begin{tabular}{|c|c|c|c|}
\hline Ensaio & Resultado & Especificação* & Unidade \\
\hline \multicolumn{4}{|l|}{ Aparência: } \\
\hline - aspecto & $\begin{array}{l}\text { - límpido e isento } \\
\text { de impureza }\end{array}$ & $\begin{array}{l}\text { - límpido e isento } \\
\text { de impureza }\end{array}$ & $(-)$ \\
\hline - cor & - amarela & - Incolor-amarela ${ }^{(1)}$ & $(-)$ \\
\hline Teor de álcool: & 26 & $25 \pm 1$ & \%vol \\
\hline \multicolumn{4}{|l|}{ Destilação: } \\
\hline$-10 \%$ & 51,0 & 65,0 - máx. & ${ }^{\circ} \mathrm{C}$ \\
\hline$-50 \%$ & 71,5 & 80,0 - máx. & ${ }^{\circ} \mathrm{C}$ \\
\hline$-90 \%$ & 163,6 & $145-190,0$ & ${ }^{\circ} \mathrm{C}$ \\
\hline - PFE & 201,8 & 220,00 - máx. & ${ }^{\circ} \mathrm{C}$ \\
\hline - resíduo & 1,2 & $2,0-$ máx. & $\%$ vol \\
\hline Massa Específica a $20^{\circ} \mathrm{C}$ & 747,5 & Anotar & $\mathrm{Kg} / \mathrm{m}^{3}$ \\
\hline $\mathrm{N}^{\circ}$ de octano motor (MON) & 82,7 & 82,0 - mín. & $(-)$ \\
\hline Índice antidetonante (IAD) & 89,3 & $87,0-$ mín. & $(-)$ \\
\hline Teor de benzeno & 0,5 & 1,0-máx. & $\%$ vol \\
\hline \multicolumn{4}{|l|}{ Composição hidrocarbonetos } \\
\hline - olefínicos & 17,9 & 30 - máx. & \%vol \\
\hline - saturados & 39,6 & $(-)$ & $\%$ vol \\
\hline - aromáticos & 15,6 & 45 - máx. & \%vol \\
\hline
\end{tabular}

`especificações da atual legislação em vigência; (-) não se aplica; (1) permitida a utilização de corante com exceção da cor azul.

São Carlos, 10 de Dezembro de 2007.

MIRIAM REGINA BATOCCHIO

Supervisor de Laboratório - Combustíveis

miriam@ccdm.ufscar.br
SABRINA APARECIDA CASARIN

Técnico de Laboratório - Combustiveis sabrina@ccdm.ufscar.br

Cláusulas de responsabilidade:

a) A amostragem relativa a este certificado é de responsabilidade do cliente e estes resultados referem-se apenas a amostra ensaiada (não extensivo a outras amostras);

b) A amostra será mantida pelo prazo de 6 meses após a emissão deste documento ou devolvidas se solicitado pelo cliente. Se forem destrutíveis serão mantidos somente os registros do serviço pelo prazo de 5 anos.

A reprodução deste certificado deve ser realizada na integra. O laboratório não é responsável em nenhum caso de interpretação ou uso indevido que se possa fazer deste documento. 